\author{
UNIVERSIDADE DE SÃO PAULO \\ FACULDADE DE FILOSOFIA, LETRAS E CIÊNCIAS HUMANAS \\ DEPARTAMENTO DE GEOGRAFIA \\ PROGRAMA DE PÓS-GRADUAÇÃO EM GEOGRAFIA
}

\title{
O PRODUTOR FAMILIAR RURAL E A DINÂMICA ECONÔMICA E SOCIAL NO ESPAÇO RURAL DA REGIÃO DE PRESIDENTE PRUDENTE NOS ANOS
}

1980-90

Célia Maria Santos Vieira de Medeiros

São Paulo

2002 


\author{
UNIVERSIDADE DE SÃO PAULO \\ FACULDADE DE FILOSOFIA, LETRAS E CIÊNCIAS HUMANAS \\ DEPARTAMENTO DE GEOGRAFIA \\ PROGRAMA DE PÓS-GRADUAÇÃO EM GEOGRAFIA
}

\title{
O PRODUTOR FAMILIAR RURAL E A DINÂMICA ECONÔMICA E SOCIAL NO ESPAÇO RURAL DA REGIÃO DE PRESIDENTE PRUDENTE NOS ANOS
} 1980-90

Célia Maria Santos Vieira de Medeiros

\begin{abstract}
Tese apresentada ao Programa de Pós-Graduação em Geografia, do Departamento de Geografia Humana da Faculdade de Filosofia, Letras e Ciências Humanas da Universidade de São Paulo, para obtenção do Título de doutor em Geografia.
\end{abstract}

Orientador: Prof. Dr. Ariovaldo Umbelino de Oliveira

Edição Revisada

São Paulo

2002 
A DEUS, EM PRIMEIRO LUGAR, PORQUE TODA BOA DÁDIVA E TODO DOM PERFEITO VÊM DO ALTO, DO PAI DAS LUZES.

A MEUS PAIS, EDISEL E CÉLIA, QUE SEMPRE ESTIVERAM NA RETAGUARDA PARA QUE EU PUDESSE CHEGAR ATÉ AQUI.

A NETO, MEU COMPANHEIRO, PELO ESTÍMULO TÃO PRECIOSO PARA REALIZAR ESTE TRABALHO.

A MEUS FILHOS AMADOS: JOÃO GABRIEL, JOSÉ LUÍS E MARINA, PELA MOTIVAÇÃO CONSTANTE DA VIDA. 


\section{AGRADECIMENTOS}

As contribuições recebidas para a realização desta pesquisa foram inúmeras; meus agradecimentos a todos aqueles que trilharam conosco este caminho. Em especial, meu muito obrigada:

a todos os agricultores e suas famílias que me receberam, prestando informações valiosas sobre suas vidas, seu trabalho e sua luta no campo, permitindo que, neste convívio, eu pudesse aprender muito sobre eles e sobre mim mesma;

ao Prof. Dr. Ariovaldo Umbelino de Oliveira, pela paciência na orientação deste trabalho e na busca constante em fazer-me repensar posicionamentos;

ao CNPq, pelo apoio recebido durante a pesquisa;

ao Departamento de Geografia da Faculdade Filosofia, Letras e Ciências Humanas da Universidade de São Paulo, sobretudo aos Professores Drs. Armen Mamigonian e Heinz Dieter Hidemann, pelas contribuições e sugestões no exame de qualificação;

à Ana e Jurema, funcionárias da seção de Pós-Graduação em Geografia, da FFLCH-USP, sempre atenciosas e gentis diante das minhas solicitações;

ao Sr. Alceu de Arruda Veiga Filho, diretor técnico do Instituto de Economia Agrícola, pelos dados fornecidos do projeto LUPA;

ao Sr. Roberto Inague, engenheiro agrônomo, diretor do Escritório de Desenvolvimento Rural de Presidente Prudente, pela atenção dispensada;

aos agrônomos e técnicos agrícolas das Casas da Agricultura visitadas, pelo acompanhamento e orientações durante o trabalho de campo;

à Mariza Sminka Tarumoto, engenheira agrônoma e consultora do SEBRAE - Presidente Prudente, pelos convites para os cursos, pelos dados fornecidos e pela troca de informações e experiências;

à Adriana, pela companhia durante as viagens realizadas; ao Jailton, Elias, Agda e Anderson pelo auxílio com as figuras e tabelas, e a todos do grupo GEDRA, cuja convivência e questionamentos foram fundamentais nessa trajetória acadêmica;

à Vera Elisabeth, Vera Sônia e Nadiege, pela ajuda com o resumo e com as correções; à Nair, pelo auxílio com as normas e a edição final deste trabalho;

à tia Iracema, pelo acolhimento carinhoso em São Paulo;

às amigas Águeda e Isa, pelo constante apoio fraternal. 
NINGUÉM LIBERTA NINGUÉM; NINGUÉM SE LIBERTA SOZINHO; OS HOMENS SE LIBERTAM EM COMUNHÃO. PAULO FREIRE 


\section{RESUMO}

Essa pesquisa objetiva compreender a dinâmica espacial do Sudoeste Paulista, através de abordagem econômica e social do espaço rural, analisando e refletindo sobre o universo da produção agrícola familiar e as possibilidades futuras deste setor frente às políticas públicas, as possíveis mudanças no dinamismo regional, e os limites que os mesmos têm enfrentado com relação à estrutura fundiária, à produção, à comercialização, aos recursos financeiros, ao acesso à tecnologia, à assistência técnica, sua representação e atuação em associações, cooperativas, sindicatos e outras entidades. As áreas pesquisadas fazem parte do Escritório de Desenvolvimento Rural de Presidente Prudente, composto de 21 municípios, entre os estratos de área de até 100 hectares. No levantamento de campo foram entrevistados produtores rurais, destacando-se questões ligadas à unidade de produção, bem como à unidade social dos agricultores familiares. A região estudada, embora apresente, desde sua formação histórica, alta concentração fundiária de caráter capitalista, com predomínio da atividade pecuária de corte extensiva, não levou, necessariamente, ao desaparecimento das unidades de produção familiares, fossem elas pequenas ou médias. Tampouco levou a uma homogeneização da produção; antes, observa-se uma dinâmica que muitas vezes inclui múltiplos caminhos, os quais proporcionam uma adaptação contraditória frente às novas circunstâncias sociais e de produção. Com relação às políticas públicas para o setor destacado neste estudo, verifica-se que o Programa Nacional de Fortalecimento da Agricultura Familiar não foi, até agora, suficiente para atender, de forma eficaz, os produtores familiares. A comercialização indireta da produção e a insegurança com relação aos preços foram fatores destacados, entre outros aspectos, como limitantes para o produtor familiar, que mostrou resistência em adotar formas de organização social que pudessem protegê-lo. Entretanto, através de estratégias, esses produtores têm sido os responsáveis por parte significativa da produção agropecuária regional, bem como da absorção de mão-de-obra no campo. Neste sentido, analisando-se processos sociais concretos, apreendem-se a diversidade e a complexidade de possibilidades neles contidas, podendo, então, apontar caminhos que possam trazer transformações ao dinamismo regional.

Palavras-chave: produtor familiar; políticas públicas; representação social. 


\begin{abstract}
This study aims to understand the space dynamics of the Paulista Southwestern region, through the economic and social approach of the rural, analyzing and reflecting on the overall family agricultural production and its future possibilities before public policies, the possible shifts in the regional dynamics, and the limits that they have faced in relation to land structure production, trade, financial resources, access to technology, and technical assistance, its representation and performance in associations, cooperatives, unions and other entities. The areas researched are parts of the Presidente Prudente Rural Development Office, formed by 21 counties, in up-to-100-hectare area levels. During the field survey, rural producers were interviewed, emphasizing matters connected to the production unit, as well as to the social unit of the family farmers. The region considered, although it has presented a high-level land concentration of capitalist character since its historical formation, and in which the animal husbandry activity of extensive slaughter has been predominant, has necessarily led neither to the disappearance of the little or large family production units, nor to a production homogenity; instead, I have observed a dynamics that has often included multiple ways, which have provided a contradictory adaptation before the new social and production circumstances. In relation to public policies for the field focused in this study, I have verified that the Family Agriculture Development National Program has not been enough to assist the family producers efficiently up to now. The indirect commercialization of the production and the insecurity in relation to prices were the main aspects in focus, among others, as limits for the family producer, who has showed resistance in adapting ways of social organization which could protect them. Nevertheless, through strategies, these very producers have been responsible for a meaningful part of the regional agricultural and animal husbandry production, as well as for labour absorption in the country. Therefore, in analyzing concrete social processes, I have realized the diversity and complexity of possibilities within them, so that, I believe it is able to indicate ways that could bring changes to the regional dynamics.
\end{abstract}

Key-words: family producer, public policies, social representation. 


\section{LISTA DE FOTOS}

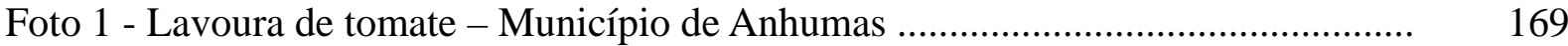

Foto 2 - Pomar comercial - laranja pêra-rio - Município de Regente Feijó ................... 169

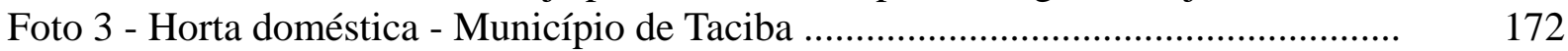

Foto 4 - Plantação consorciada de abóbora, jiló, pimentão e berinjela - Município de Indiana

Foto 5 - Plantação de batata-doce - Município de Presidente Prudente ........................ 175

Foto 6 - Terra preparada para plantação de melancia - Município de Caiabú ................ 175

Foto 7 - Pomar - manga, pêra e banana - Município de Presidente Bernardes ............. 179

Foto 8 - Horta comercial - Município de Álvares Machado ......................................... 179

Foto 9 - Horta comercial - Município de Regente Feijó ............................................... 204

Foto 10 - Pomar - laranja baiana e limão - Município de Alfredo Marcondes................ 204

\section{LISTA DE FIGURAS}

Figura 1 - Mapa da 10a Região Administrativa de Presidente Prudente

Figura 2 - A Penetração e a Posse dos Mineiros no Vale do Paranapanema.................... 87

Figura 3 - O Município de Presidente Prudente - 1921................................................. 89

Figura 4 - Produção Total das Culturas do EDR de Presidente Prudente em ha............ 105

Figura 5 - Produção Total das Culturas do EDR de Presidente Prudente em ha............ 106

Figura 6 - Produção Total das Culturas do EDR de Presidente Prudente em ha............ 107

Figura 7 - Regionais Agrícolas do Estado de São Paulo............................................... 128

Figura 8 - Regional Agrícola de Presidente Prudente ................................................... 131

Figura 9 - Estrutura Fundiária - Municípios do EDR de Presidente Prudente -SP......... 152

Figura 10 - Estrutura Fundiária - Municípios do EDR de Presidente Prudente -SP....... 153

\section{LISTA DE QUADROS}

Quadro 1 - PRONAF - Características principais dos beneficiários

Quadro 2 - Evolução da área agrícola e de pastagens - DRA - Presidente Prudente 1940 - 1995/96

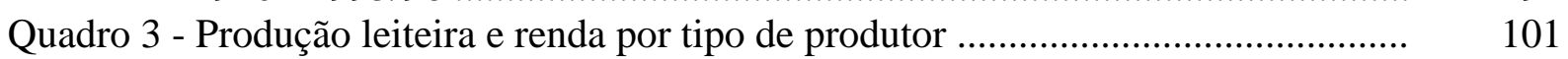

Quadro 4 - Regionais Agrícolas do Estado de São Paulo ........................................... 129

\section{LISTA DE TABELAS}

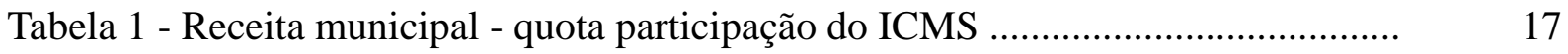

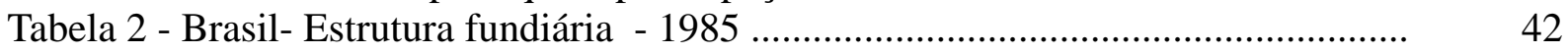

Tabela 3 - Brasil- Estrutura fundiária - 1995/96 ............................................................... 43

Tabela 4 - Índice de lotação das pastagens e efetivo bovino na MRG de Presidente Prudente e do Estado de São Paulo - 1950 - 1995/96

Tabela 5 - Evolução da produção de leite na MRG de Presidente Prudente e no Estado de São Paulo - 1950-1996 (em mil litros) 
Tabela 6 - Utilização das terras nos estabelecimentos agropecuários da MRG de Presidente Prudente - 1950 - 1995/96

Tabela 7 - Área e produção das principais atividades agropecuárias - DRA 1974/5 1996/7

Tabela 8 - Evolução da produção e da área ocupada com as principais culturas na MRG de Presidente Prudente - 1950-1995/96

Tabela 9 - MRG de Presidente Prudente: volume da produção agrícola por estrato de área - 1995/96

Tabela 9.1 - MRG de presidente prudente: valor da produção por estrato de área 1995/96 (em mil reais)

Tabela 10 - Área e produção das principais frutíferas na MRG de Presidente Prudente, 1980-1995/96

Tabela 11 - População urbana e rural da MRG de Presidente Prudente e do Estado de São Paulo, 1950-1996

Tabela 12 - População urbana e rural - 1980

Tabela 13 - População urbana e rural - 1996

Tabela 14 - Condição do produtor na MRG de Presidente Prudente - 1980 1995/1996

Tabela 14.1 - Pessoal ocupado nos estabelecimentos agropecuários do Estado de são Paulo e da MRG de Presidente Prudente - 1980 e 1995/96

Tabela 14.2 - Condição do Produtor por Município do EDR de Presidente Prudente...

Tabela 15 - Estrutura fundiária - 1985

Tabela 16 - EDR de Presidente Prudente - número de propriedades por estrato de área, 1995/96

Tabela 16.1 - EDR de Presidente Prudente - número de propriedades com área até 100 ha, 1995/1996

Tabela 17 - Número de estabelecimentos rurais por municípios - EDR de Presidente Prudente - 1975 e 1995/96

Tabela 18 - Idade dos informantes

Tabela 19 - Tempo na atividade

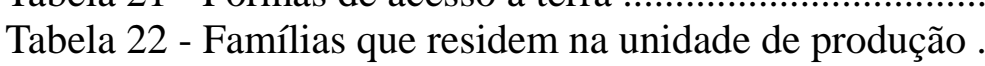

Tabela 23 - Principal fonte de renda familiar principal fonte de renda familiar .............

Tabela 24 - Área das unidades de produção visitadas

Tabela 25 - Sistema de produção

Tabela 26 - Assistência técnica

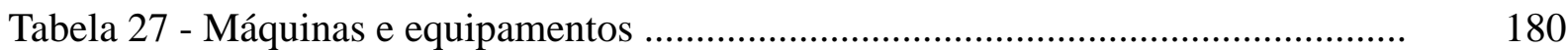

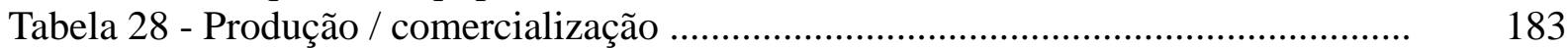

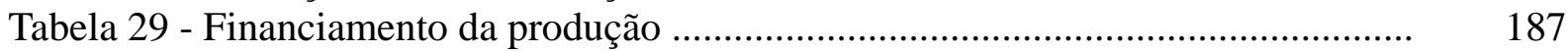

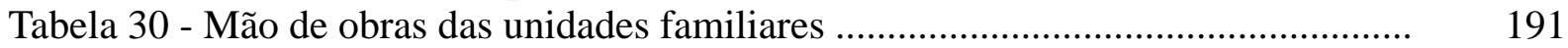

Tabela 31 - Formas de organização dos produtores familiares ..................................... 196

\section{LISTA DE GRÁFICO}

Gráfico 1 - População Urbana e Rural dos municípios do EDR de Presidente Prudente 1980 e 1996. 


\title{
SUMÁRIO
}

\author{
LISTA DE FOTOS \\ LISTA DE FIGURAS \\ LISTA DE QUADROS \\ LISTA DE TABELAS
}

INTRODUÇÃO

PARTE I

Capítulo 1 - PROCEDIMENTOS METODOLÓGICOS

Capítulo 2 - PRODUÇÃO FAMILIAR NO BRASIL - ABORDAGENS TEÓRICAS

E PROCESSOS SOCIAIS E POLÍTICOS

Capítulo 3 - O DESENVOLVIMENTO DO CAPITALISMO NO CAMPO

BRASILEIRO

3.1 Agricultura brasileira nas décadas de 1980 e de 1990 - aspectos fundiários, econômicos e políticos

Capítulo 4 - O ESTADO, A AGRICULTURA E AS POLÍTICAS PÚBLICAS NO

BRASIL

4.1 O Estado e seu papel na sociedade .....................................................................

4.2 Notas sobre a Política Agrícola Brasileira - décadas de 1960 - 1980 .................... 54

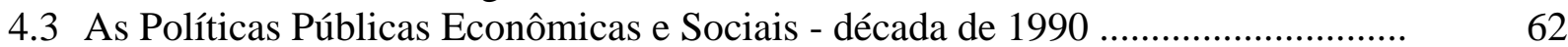

4.4 Políticas Públicas Estaduais - Governo do Estado de São Paulo ............................

4.5 Programas de outras entidades ..............................................................................

4.6 Políticas Públicas e os municípios da Região Administrativa de Presidente Prudente

Capítulo 5 - CONSIDERAÇÕES TEÓRICAS SOBRE O CONCEITO DE REGIÃO

PARTE II

Capítulo 6 - PROCESSO HISTÓRICO DA OCUPAÇÃO DA REGIÃO DE PRESIDENTE PRUDENTE

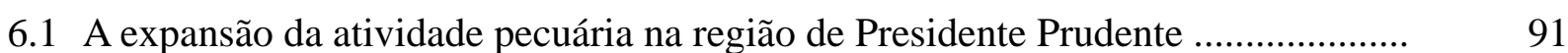

6.1.1 As pastagens ......................................................................................... 92

6.1.2 As raças do rebanho de corte ............................................................ 95

6.1.3 A indústria de carne bovina ................................................................... 95

6.2 A atividade pecuária na região de Presidente Prudente ....................................... 97

6.3 A atividade agrícola na região de Presidente Prudente ........................................... 104

Capítulo 7 - O PRODUTOR FAMILIAR DA REGIÃO DE PRESIDENTE PRUDENTE 
7.1 A dinâmica social e econômica do espaço rural do Sudoeste Paulista - anos 8090

7.2 Mobilidade populacional - região de Presidente Prudente .

7.3 Relações de produção na agricultura na MRG de Presidente Prudente ...

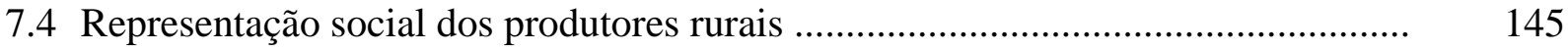

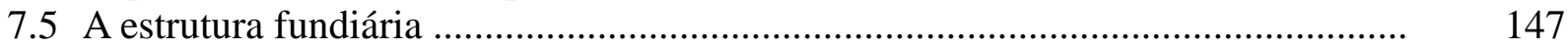

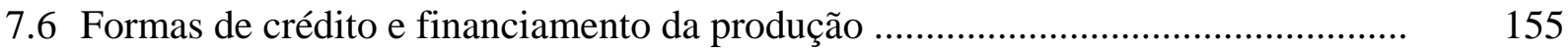

Capítulo 8 - CARACTERÍSTICAS E DEPOIMENTOS DOS PRODUTORES FAMILIARES ENTREVISTADOS

ANEXOS

Anexo 1 - Questões da entrevista junto aos agricultores familiares do EDR de Presidente Prudente e transcrição das entrevistas Anexo 2 - As 10 principais culturas/área por Município - dados LUPA - 1997 Regional Agrícola de Presidente Prudente 


\section{INTRODUÇÃO}

Neste estudo, buscou-se compreender a dinâmica espacial do Sudoeste Paulista, destacando o papel representado pelo produtor familiar ${ }^{1}$ nesta dinâmica, através de uma abordagem social e econômica ${ }^{2}$. O período estudado refere-se às décadas de 1980 e 1990. Adentrar esse universo me possibilita desvendar a riqueza da vida e do trabalho de um grupo social, pouco visível para alguns, em uma sociedade que tem priorizado outros valores.

Assim, a observação da realidade, juntamente com leituras de diversos trabalhos e pesquisas, levou-me a refletir e a indagar sobre a situação atual do espaço rural no Sudoeste Paulista e sobre a questão de seu desenvolvimento econômico e social.

Muitos estudos têm apontado que o processo de desenvolvimento tende a separar o surgimento de novos empregos do grau de urbanização regional. Um amplo programa de pesquisas desencadeado pela OCDE (Organização para Cooperação e Desenvolvimento Econômico,1996) mostrou que certas regiões rurais dos países mais desenvolvidos voltaram a ter dinamismo econômico, enquanto as mais urbanizadas se estagnaram ou mesmo regrediram.

Tais mudanças ainda precisam de estudos para serem compreendidas com maior clareza; entretanto, já direcionam para a negação da idéia muito comum da inevitável decadência das regiões baseadas principalmente em economias rurais.

Contudo, o segredo desta alteração de tendência é revelado através do grau de diversificação das economias regionais, invertendo as avaliações feitas anteriormente das formas de produção do setor agropecuário. Setores que foram considerados ineficientes, hoje são tidos como fundamentais para o desenvolvimento das atividades de origem rural.

Estes estudos ressaltam, de forma particular, o papel dos estabelecimentos agrícolas, em que o núcleo familiar pode formar um pequeno negócio, na maioria das vezes informal, com grande habilidade empreendedora e que estimulam entre si uma ética de trabalho ímpar.

\footnotetext{
1 “Camponês modernizado,[...] empreendedor e comunitário, economicamente moderno e socialmente conservador, enraizado nas tradições locais e culturalmente religioso [...]”, segundo Martins (2002, p. 45).

2 Esta proposta teórica de estudo não é compartilhada pelo orientador desta tese, que centra seus estudos na concepção camponesa desses sujeitos sociais.
} 
Mas, o que essas pesquisas têm a ver com a dinâmica econômica e social da região de Presidente Prudente?

A região de Presidente Prudente, mais especificamente a Microrregião Geográfica com 30 municípios, conta com 82,9\% de seus estabelecimentos rurais possuindo áreas inferiores a 100 hectares, segundo dados do censo agropecuário da FIBGE-1995/96; estas ocupam 18,5\% da superfície total da região, sendo que grande parte desses estabelecimentos é dirigida ou arrendada por famílias que aí trabalham e têm se reproduzido socialmente.

Estas áreas são responsáveis pelo volume considerável na produção de algumas culturas, ou seja, 85,7\% da mandioca, 92,1\% de maracujá, 80,9\% da melancia, 91,6\% da produção de uva de mesa, entre outras.

Com relação ao valor da produção agrícola regional, os estabelecimentos com área inferior a 100 hectares, em 1995/96, apresentam valores expressivos nas culturas de batata-doce, com 89,1\%; manga, com 87,7\%; maracujá, com 90,4\%, apenas para destacar alguns. A produção vegetal, no seu conjunto, representou, em 1995/96, 36,3\% do valor da produção total da região, e a produção animal respondeu por 63,7\% do total.

Vale a pena ressaltar ainda que, nestes estabelecimentos, a pecuária na região, foi responsável por 21,5\% do rebanho bovino, e de 53,8\% da produção regional de leite. Já com relação ao pessoal ocupado no meio rural, nesses estabelecimentos de até 100 hectares, os responsáveis e membros não remunerados, ou seja, a mão-de-obra familiar, representam 65,1\% do conjunto da mão-de-obra empregada.

Nota-se, então, a importância que esses sujeitos sociais desempenham para o dinamismo da região, mesmo em face de limitações de ordem fundiária, tecnológica, de recursos financeiros e de comercialização, entre outros. Além disso, deve-se ter em mente que, se outros setores buscam a maximização da competitividade através do agronegócio, buscando gerar uma especialização da produção, é possível e necessário que haja a ampliação das oportunidades para os produtores familiares que possam lhes proporcionar transformações sociais e econômicas.

Sendo assim, a tese defendida neste trabalho é que a produção familiar representa um papel social e econômico importante, embora encontre dificuldades e limites, frutos da história social, política, econômica, agrícola e agrária brasileira. E, ao contrário daqueles que acreditam no desaparecimento das unidades produtivas, dirigidas pela família, a 
pesquisa de campo mostrou que as mesmas permanecem, de forma que as teorias que buscam explicar essa realidade devam ser permanentemente revistas e discutidas. Acredita-se que estes produtores familiares, se puderem superar limitações de caráter organizacional, políticos, tecnológicos, comerciais, etc., poderão refletir, significar e impor um maior dinamismo à região.

Na parte I, após a introdução, há a descrição do processo metodológico adotado nesta pesquisa. Desta forma, ao me propor a tarefa de compreender a realidade deste espaço, é fundamental que o capítulo 2 se inicie com uma discussão teórica acerca do produtor familiar e dos processos sociais e políticos que envolvem esse grupo. No capítulo 3, discorre-se sobre o capitalismo no campo, no final do século XX, bem como analisa-se a evolução da agricultura brasileira neste mesmo período. No capítulo 4, aborda-se o papel do Estado para a formulação das políticas públicas federal, estadual e municipal para a agricultura, incluindo a situação fundiária histórica brasileira.

Ao tratar do Sudoeste Paulista, ou seja, da região de Presidente Prudente e da produção familiar faz-se algumas considerações teóricas sobre o conceito de região, no capítulo 5.

Na parte II, no capítulo 6, destacam-se aspectos como a formação histórica da área em foco, a expansão da atividade pecuária e da atividade agrícola na região de Presidente Prudente. Os dados sobre a evolução da estrutura fundiária, da mobilidade populacional, da produção agropecuária, as inovações tecnológicas, a atuação dos produtores nas associações, cooperativas, sindicatos, etc. são analisados no capítulo 7. E, finalmente, no capítulo 8, estão as características e as falas dos produtores familiares entrevistados, no qual ressalta-se o papel desses sujeitos na dinâmica regional. Após o levantamento, pode-se refletir sobre a realidade e pensar alternativas que contribuam para mudanças de âmbito social e econômico.

A região de Presidente Prudente está localizada no Sudoeste do Estado de São Paulo. Segundo a FIBGE-2000, a microrregião geográfica de Presidente Prudente conta com 30 municípios ${ }^{3}$, em uma área de $17.513,2 \mathrm{~km}^{2}$, e uma população total de 544.215

\footnotetext{
${ }^{3}$ Alfredo Marcondes, Álvares Machado, Anhumas, Caiabu, Caiuá, Emilianópolis, Estrela do Norte, Euclides da Cunha Paulista, Indiana, João Ramalho, Marabá Paulista, Martinópolis, Mirante do Paranapanema, Narandiba, Piquerobi, Pirapozinho, Presidente Bernardes, Presidente Epitácio, Presidente Prudente, Presidente Venceslau, Rancharia, Regente Feijó, Ribeirão dos Índios, Rosana, Sandovalina, Santo Anastácio, Santo Expedito, Taciba, Tarabai e Teodoro Sampaio.
} 
habitantes, dos quais 93,0\% residem na zona urbana e 7,0\% na zona rural. A cidade de Presidente Prudente se caracteriza, também, por ser centro regional da $10^{\mathrm{a}}$ Região Administrativa, que compreende 53 municípios. (Figura 1). A região de Governo de Presidente Prudente compreende 31 municípios, sendo também conhecida como região da Alta Sorocabana. Na Região Administrativa de Presidente Prudente existem outras duas Regiões de Governo: Dracena e Adamantina, que compreendem juntas 22 municípios.

Neste estudo, utiliza-se dados da FIBGE, bem como da divisão regional adotada pela da Secretaria de Agricultura e Abastecimento do Estado de São Paulo - SAA, que, atualmente divide o estado em 40 regionais (Figura 4), ou seja, cada uma delas corresponde a um Escritório de Desenvolvimento Rural (EDR), da Coordenadoria de Assistência Técnica Integral (CATI).

Em razão de se optar pela realização de trabalho de campo, tendo como foco produtores rurais que residem nas propriedades com suas famílias, nas quais fez-se um levantamento empírico qualitativo, pareceu muito trabalhoso cobrir uma região tão extensa. Pelo número de municípios da Microrregião da FIBGE, utilizou-se, em termos espaciais, a divisão da Secretaria de Agricultura e Abastecimento do Estado de São Paulo- SAA, que abrange apenas 21 municípios ${ }^{4}$, embora tenha trabalhado também com dados secundários, tanto da SAA, quanto da FIBGE.

É importante citar que a cidade de Presidente Prudente representa, na área pesquisada, o papel de centro regional de comércio e serviços. Sua gênese e desenvolvimento estão intimamente relacionados com a residência de produtores rurais, ligados à agricultura ou à pecuária, pois os mesmos empregaram na cidade a renda auferida nestas atividades, através da aquisição de bens de consumo (veículos, utilitários, equipamentos), manutenção familiar (educação, lazer), insumos para a propriedade e sempre se utilizaram da infra-estrutura financeira e de serviços existente neste centro urbano para realizar suas transações gerais.

Entretanto, nas últimas décadas do século XX, esta característica tem sofrido algumas alterações através da inclusão de outros grupos que proporcionaram a ampliação de serviços oferecidos pela cidade (universidades, serviços médicos, shopping centers, grandes redes de supermercados, etc.).

\footnotetext{
${ }^{4}$ Alfredo Marcondes, Álvares Machado, Anhumas, Caiabu, Emilianópolis, Estrela do Norte, Iêpe, Indiana, João Ramalho, Martinópolis, Nantes, Narandiba, Pirapozinho, Presidente Bernardes, Presidente Prudente, Rancharia, Regente Feijó, Sandovalina, Santo Expedito, Taciba e Tarabai.
} 


\section{FIGURA 1 MAPA DA 10ª. REGIÃO ADMINISTRATIVA DE PRESIDENTE PRUDENTE}
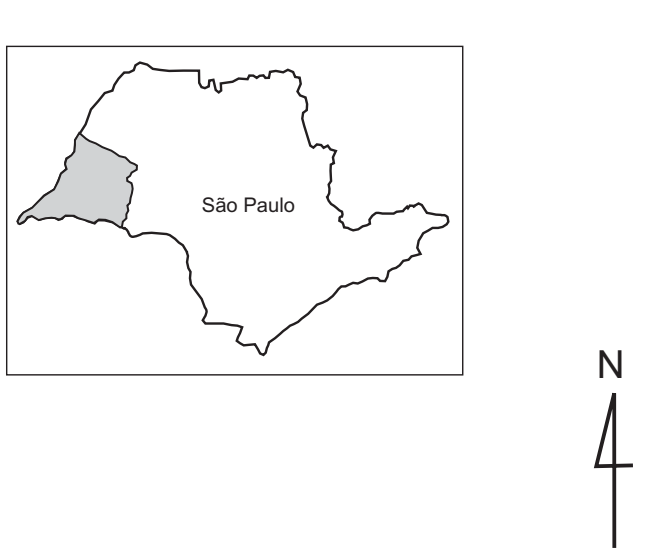

LEGENDA

Municípios do EDR de

Presidente Prudente

Município não integrante da

$10^{a}$. Região Administrativa

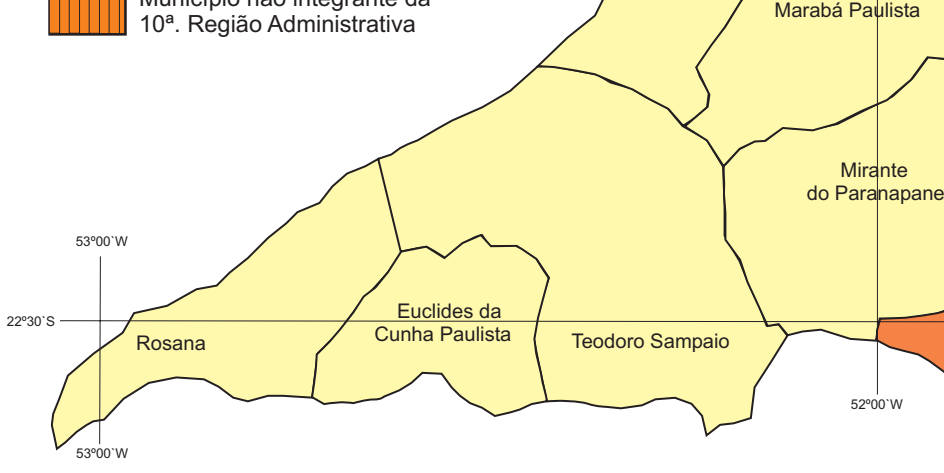

FONTE: Governo do Estado de São Paulo

- Instituto Geográfico e Cartográfico (IGC)

- Escritório Regional de Articulação e Planejamento (ERPLAN)

ORG: Célia Santos Medeiros

ESCALA

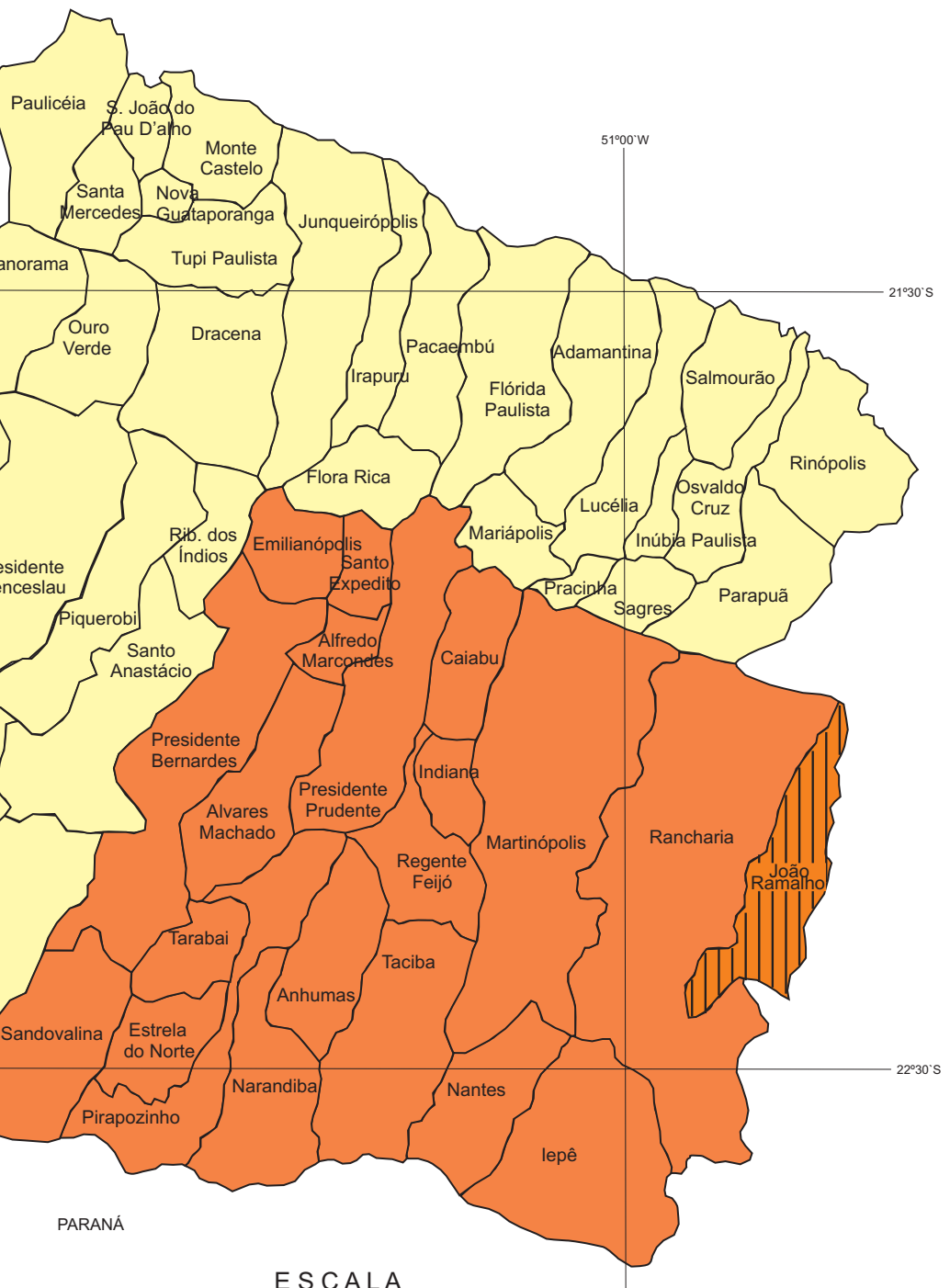

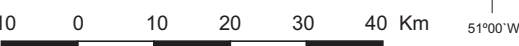


Assim, o que se observa é que a região, cuja principal atividade econômica é a atividade agropecuária, tem apresentado uma dinâmica econômica e social baixa.

Constatou-se que este universo, o da atividade agropecuária e do produtor rural, é bastante diverso e complexo. De um lado, encontram-se nesta região produtores rurais, proprietários, em sua maioria, de unidades de produção com áreas acima de 200 ha, cuja atividade principal é a pecuária bovina de corte; enfrentam dificuldades, seja com relação à comercialização, aos custos de produção, ao desgaste das pastagens e mesmo quanto à expansão de seus empreendimentos. Este tema foi tratado por essa pesquisadora em trabalho anterior 5 .

Por outro lado, neste mesmo espaço, comparecem também produtores rurais que exercem outras atividades, principalmente ligadas à agricultura e à pecuária leiteira, que têm enfrentado maiores limitações que aqueles, seja pelo fato de possuírem unidades produtivas menores, em média de 20 ha, ou por terem menor acesso a financiamentos e à tecnologia, etc..; estes se distinguem por aí residirem, por trabalharem com suas famílias e por utilizarem mão-de-obra temporária e sazonal. Além desses dois grupos acrescentam-se, aqueles que têm sido assentados através do programa de Reforma Agrária e aqueles que ainda não têm terra e que a reivindicam, fazendo parte de movimentos sociais, como o Movimento dos Trabalhadores Rurais Sem Terra (MST), entre outros.

Percebe-se, a complexidade deste espaço e de seus atores sociais; entretanto, interessa apreender neste trabalho a análise e a reflexão dos atores que se chama neste trabalho de produtores familiares, assim, aprofunda-se a abordagem teórica desse tema no capítulo 1.

Desta forma, ao aspirar por um maior dinamismo econômico e social, pergunta-se: qual é a importância deste grupo social para a região? Como este grupo tem se articulado para reivindicar mudanças na produção, na comercialização, na distribuição, etc.? E, com relação ao poder público: tem ele conseguido através de suas políticas, proporcionar mudanças onde fosse possível uma geração de renda mais justa, bem como a ampliação de postos de trabalho, tanto no campo como na cidade?

Em se tratando do desenvolvimento econômico e social de uma região, um fator importante é o montante dos recursos disponíveis para o investimento e o financiamento da produção, seja ela industrial, agropecuária, etc.

\footnotetext{
${ }^{5}$ MEDEIROS, Célia Maria Santos V. O tradicional e o moderno na atividade pecuária de corte: Produtores rurais pecuaristas residentes em Presidente Prudente. FCT/UNESP, 1997.
} 
Assim, com relação aos recursos públicos, o ICMS (Imposto sobre Circulação de Mercadorias e Serviços), é a principal fonte de receita do Estado e um dos parâmetros para medir o desenvolvimento econômico de uma região, embora sua fórmula de distribuição receba críticas por parte dos envolvidos com as administrações municipais.

Observando os dados da Fundação SEADE, com relação à arrecadação de ICMS na Região Administrativa de Presidente Prudente, pode-se notar um aumento na arrecadação nas últimas décadas. Entretanto, uma comparação com outras regiões do Estado de São Paulo, nos anos 1985 e 1995, conforme a tabela 1, demonstra que a RA de Presidente Prudente não tem conseguido diminuir a diferença de sua arrecadação, quando comparada as demais RAs.

TABELA 1. RECEITA MUNICIPAL - QUOTA PARTICIPAÇÃO ICMS (equivalente de reais de 1996)

\begin{tabular}{|l|c|c|}
\hline \multicolumn{1}{|c|}{ Região Administrativa } & 1985 & 1995 \\
\hline S.J. RIO PRETO & 62.006 .384 & 160.133 .169 \\
\hline BAURU & 60.314 .372 & 120.943 .870 \\
\hline MARÍLIA & 52.045 .076 & 118.614 .238 \\
\hline ARAÇATUBA & 36.147 .358 & 114.162 .950 \\
\hline PRES. PRUDENTE & 41.036 .114 & 98.812 .806 \\
\hline
\end{tabular}

Fonte: Fundação SEADE

Cabe esclarecer que a Constituição Federal determina que 25\% do total desse imposto arrecadado pelo Estado sejam destinados aos seus municípios, a chamada quota - parte do ICMS. Desta maneira, dentre os critérios desta distribuição está o de área cultivada, com o peso de 3\%. Este critério pode ser considerado pelo tipo de produtividade para minimizar distorções existentes nos índices de participação dos municípios agrícolas que possuem valor adicionado menor, ao se comparar com municípios industrializados, porque a produção agrícola é isenta da cobrança do ICMS e ou por ter seus produtos diferidos de cobrança.

Apesar de dados mais recentes apontarem para uma recuperação, onde Presidente Prudente aparece no grupo das dez cidades que mais tiveram crescimento percentual no repasse do ICMS na década de 1990-2000, o que significou mais investimentos para a região, conforme a Folha de São Paulo (27/3/00, 3-7), esses dados não revelam se 
houve também um aumento da produtividade agrícola desta área, o que possibilitaria o retorno de mais investimentos ao município, que se refletissem em melhorias sociais para o homem do campo.

Outro fator importante para o desenvolvimento econômico e social de uma região é o grau de mobilização política enquanto grupo social e produtivo; ao se organizar, ele tem um poder maior de reivindicar mudanças que certamente transformam o cenário atual. Cabe destacar, neste aspecto, a atuação do MST e da UDR, como forças antagônicas, no que diz respeito à questão agrária na região. Esses grupos, certamente, são importantes para impor transformações; contudo eles não serão aprofundados nesta pesquisa ${ }^{6}$.

Um olhar crítico sobre a área rural destacada neste trabalho aponta-se para uma realidade de possibilidades sociais e econômicas ainda limitadas, aliada ao descaso político com este setor, realidade esta justificada muitas vezes pelas condições de degradação ambiental provocada pelo uso indiscriminado do solo neste último quartel do século XX. A meu ver isso, também é fruto de uma ação/articulação política pouco ativa por parte deste grupo produtivo, bem como de toda a sociedade que valoriza mais as atividades e as produções urbanas.

Assim, torna-se imprescindível que os atores ligados às atividades agropecuárias, ao poder público, a empresários e à instituições de pesquisa busquem opções que visem melhorar esse quadro.

Desta forma, pareceu-me pertinente que este trabalho em Geografia Agrária procure analisar e revelar como as relações de produção, de comercialização, de financiamento da produção, de reprodução social têm ocorrido no campo, assim como compreender como os atores dessas relações, sejam eles grupos, associações, sindicatos, órgãos públicos ou privados, têm agido e indicar as possibilidades, limites e perspectivas de mudanças, trabalhando no sentido de desmistificar as aparências e tentando revelar as faces reais dos agentes que produzem este espaço.

\footnotetext{
${ }^{6}$ Cf. Leite (1998), Fernandes (1994) entre outros.
} 
PARTE I 


\section{CAPÍTULO 1 - PROCEDIMENTOS METODOLÓGICOS}

Para o desenvolvimento do estudo da dinâmica econômica e social do espaço rural do Sudoeste Paulista e a produção familiar foram feitas leituras onde se delineou o referencial teórico e este, juntamente com as disciplinas do curso de pós-graduação, possibilitaram compreender as relações dinâmicas e contraditórias do espaço rural.

Com relação aos procedimentos metodológicos adotados nessa pesquisa e como parte do esforço em compreender a realidade social e econômica que nos cerca, acredito que cabe ao pesquisador impor uma certa ordem entre objetos e pessoas, mesmo que, ao fim desta tarefa, notar-se que ela nunca poderá ser realizada como expressão completa da realidade; entretanto, é preciso que se busque o significado dos fatos e das relações sociais, em suas múltiplas formas, na sua posição na totalidade, pois, ao se apresentar de forma organizada, cada parte não pode ser compreendida sem a outra; contudo, deve-se estar consciente de que, ao realizar escolhas, vai-se ganhar e, ao mesmo tempo, perder aspectos da capacidade de compreensão da sociedade.

Nesse sentido,

A abordagem e interpretação da realidade pressupõem, portanto, a escolha de uma estruturação teórica que irá definir os princípios de articulação entre os componentes do sistema, ou seja, a maneira como abordaremos um tal grupo, uma dada sociedade. Não há estruturação mais verdadeira que a outra, tratam-se de alternativas que irão orientar nosso olhar de maneira a enfatizar ou, ao contrário, a menosprezar determinados aspectos da realidade. [...] Aceitar a relatividade ideológica de uma classificação tipológica não significa, porém, abolir o rigor conceptual metodológico mas estarmos atentos para os limites do conhecimento sobre a realidade. (CARNEIRO, 1999, p.326).

Assim, o melhor modelo ou a melhor estruturação seria aquele que possibilitasse a explicação do conjunto dos fatos levantados pela observação, bem como fosse passível de ser legitimado como a melhor representação da realidade.

A proposta para esta pesquisa - a dinâmica social e econômica no espaço rural do Sudoeste Paulista e a produção familiar - será a busca por dar visibilidade às unidades familiares da região de Presidente Prudente. Essa visibilidade será entendida neste trabalho, tanto através, de questões relacionadas à reprodução social deste grupo, quanto a, de 
sua inserção na economia, seja ela local, regional, etc., bem como de suas representações políticas e da atuação do Estado junto a esse setor.

Desta forma, antes de efetivar mais detalhadamente essa proposta é necessário esclarecer que usarei nesse trabalho a expressão produção familiar entendida em termos gerais, como aquela "unidade de produção agrícola onde propriedade e trabalho estão intimamente ligados à família”, conforme trata Lamarche (1993), embora tenha conhecimento de que esse termo possa englobar uma grande diversidade de produtores, o que torna impossível reconhecer um referencial empírico homogêneo, questão analisada por Moreira (1998), entre outros.

Sendo assim, o termo agricultura ou produção familiar indicaria grupos sociais que são heterogêneos e definições muitas vezes divergentes, portanto não caberia identificar o produtor familiar como uma classe social no sentido marxista do termo, pois não vou opor agricultor familiar á camponês ou a agricultura capitalista a não capitalista, debate assistido desde a década de 1970; ao contrário, respeitarei as diferentes posições teóricas.

Neste trabalho, ressalto que a expansão da agricultura capitalista não levou, necessariamente, ao desaparecimento das unidades de produção familiares, fossem elas pequenas ou médias, ou, tampouco, a uma homogeneização da produção. Preferencialmente, observei uma dinâmica que muitas vezes inclui múltiplos caminhos, os quais proporcionarão uma adaptação contraditória frente às novas circunstâncias de produção; neste sentido, ao analisar processos sociais concretos, deve-se principalmente tentar apreender a diversidade de possibilidades contidas neles.

Ao buscar entender o papel da produção familiar na dinâmica social e econômica no espaço rural da região de Presidente Prudente, tentarei captar mais as tendências desse grupo do que situações cristalizadas. Para tanto, além dos dados secundários e quantitativos, utilizei dados primários qualitativos, usando o recurso da observação participante e de entrevistas na pesquisa de campo, onde, conforme Cicourel (1980), esses dois procedimentos procuram ser complementares.

Nesse sentido, o autor esclarece que,

A participação intensiva restringe a padronização que as entrevistas permitem, mas a participação dá uma visão mais íntima do processo social. Sem algum tipo de sondagem sistemática e de perguntas durante a observação participante, o método seria de valor limitado para verificar hipóteses. A importância de uma teoria sistemática torna-se óbvia aqui para 
que o pesquisador possa ter controle sobre suas atividades enquanto observador participante. (CICOUREL, 1980. p.116).

Com relação às entrevistas, as mesmas foram feitas em duas etapas; na primeira, realizei uma conversa informal com os entrevistados; após essa conversa elaborei um roteiro de questões abertas, abrangendo tópicos relacionados ao tema da pesquisa. $\mathrm{Na}$ segunda etapa, optei pela técnica de gravador e registro da informação viva ${ }^{7}$, pois essa técnica possibilita desvendar questões inesperadas e leva-se a conhecer o "interior" de toda uma realidade social, partindo da experiência vivida pelo entrevistado, cuja maneira de ver e de sentir o mundo pode ser muito diferente da do entrevistador.

Após as entrevistas gravadas, fiz a transcrição das falas, quando tive a oportunidade de posicionar-me tanto no interior como no exterior dessa experiência, pois, segundo Queiroz (1991, p.85), “o cotidiano está sempre presente nas narrativas; a brevidade ou o exagero dos relatos, além de permitir o seu conhecimento, levam diretamente ao conhecimento das mentalidades, dos universos de pensamento, que também são objetos da pesquisa”.

Com relação aos dados secundários e quantitativos, utilizei dados da FIBGE, SEADE, Conjuntura Prudente 93, 97 da FCT/UNESP, IEA, SAA, Diagnósticos e relatórios do Escritório de Desenvolvimento Rural de Presidente Prudente (EDR), Prefeitura Municipal, SEBRAE, IPEA / PNUD, entre outros, que deram subsídios para análises. Além disso pesquisei a historicidade da mobilidade espacial da população e, da estrutura fundiária, através de dados da FIBGE, quando aprofundei a compreensão e a análise da ocupação do espaço, objeto desse estudo.

Os dados da FIBGE e do Levantamento de Unidades de Produção AgrícolaProjeto LUPA que foram analisados, revelaram dados sobre a capacidade disponível no espaço rural para que se possam implementar possíveis inovações, não apenas tecnológicas, mas também organizacionais e institucionais - legais.

Após a definição de algumas categorias como as áreas e os estratos de área, o número de produtores, de produtos agrícolas, da comercialização, do nível tecnológico, entre outras, fiz o levantamento empírico e de campo, entrevistando produtores rurais, técnicos e engenheiros agrônomos, associações e, visitando propriedades rurais, etc.

\footnotetext{
${ }^{7}$ Cf. Queiroz, M. I. P. (1991)
} 
Assim, como etapa final, efetuei a pesquisa de campo junto aos produtores familiares dos 21 municípios que compõem o EDR de Presidente Prudente, ou seja, produtores proprietários e (ou) arrendatários.

Selecionei 63 produtores familiares ${ }^{8}$, três em cada município, com unidades de produção de até 100 ha, tanto aleatoriamente quanto através de informações de engenheiros e técnicos da Coordenadoria de Assistência Técnica Integral - CATI e do Escritório de Desenvolvimento Rural de Presidente Prudente.

Construí material cartográfico através dos dados obtidos, espacializando geograficamente a produção, a produtividade, a estrutura fundiária, etc., para análise e críticas. Utilizei também programas como COREL DRAW9 (Figuras 1, 4, 5, 6 e 7), AutoCAD Map (Figuras 2 e 3) e sítios da Internet (Figura 8).

\footnotetext{
${ }^{8}$ Conforme Lamarche, 1993.
} 


\section{CAPÍTULO 2 - PRODUÇÃO FAMILIAR NO BRASIL - ABORDAGENS TEÓRICAS E PROCESSOS SOCIAIS E POLÍTICOS}

O processo histórico brasileiro demonstra que a grande propriedade ocupou sempre um lugar dominante, sendo um modelo socialmente reconhecido, tanto que, como se pode observar no capítulo 4, as políticas públicas para a agricultura sempre a privilegiaram, pois deram condições para sua modernização e conseqüente reprodução.

Por outro lado, a produção agrícola familiar teve um papel marginal na sociedade brasileira, diferentemente de países como a França, por exemplo, onde, segundo Wanderley (1995), ela é estimulada; no Brasil, o campesinato ${ }^{9}$ foi um grupo “bloqueado”, “impossibilitado de desenvolver suas potencialidades enquanto forma social específica de produção”. (WANDERLEY. 1995, p.38)

Desta forma, as abordagens teórico-metodológicas sobre a agricultura familiar nas Ciências Sociais passaram por variadas vertentes; e, na explanação que farei delas, poderei deixar de destacar algumas; contudo, isso não as torna excludentes em um todo maior sobre este assunto pois podem, inclusive, aparecer de forma articulada em uma mesma análise, e, ainda, algumas serão apenas citadas, para que assim se possa ter uma visão ampla desta temática.

O campesinato foi tema de importantes trabalhos realizados no Brasil, nas décadas de 1950, 1960 e $1970^{10}$. Entre os sociólogos rurais e antropólogos, o enfoque se dava no estudo do campesinato, das comunidades, na descrição e na caracterização da estrutura agrária brasileira. Entre os geógrafos, segundo Ferreira (1998), as análises eram pautadas pelo estudo do habitat rural, e abordavam de forma abrangente o trabalho e a produção familiar ${ }^{11}$.

\footnotetext{
9 Citando Cardoso (2002), esclareço que, “Na medida em que 'campesinato’ não é, em sua origem um conceito cientificamente construído mas, sim, uma generalização oriunda do sentido comum que, a posteriori, os que pesquisam as sociedades humanas tentam transformar em conceito, é preciso sempre recordar que aquilo que é aparentemente dado ou evidente na noção de campesinato pode ser altamente ilusório. Outrossim, nunca se deve esquecer a grande heterogeneidade, no tempo e no espaço, dos campesinatos que os pesquisadores escolham como objeto de análise.” (p. 31). Desta forma, o termo campesinato é usado aqui para referir-se ao produtor / agricultor familiar, proprietário ou não da terra, que organiza sua produção também para o mercado e que, diferentemente do camponês europeu, tem uma visão de mundo e relacionamentos políticos e sociais de características tradicionais.

${ }^{10}$ Lecoq-Müller (1951), Cândido (1964), Queiroz (1967), Fukui (1975), apenas para destacar alguns.

${ }^{11}$ Monbeig (1944 e 1984), Waibel (1958), Petrone (1961), entre outros.
} 
É importante destacar que, autores como Chayanov, Mendras, Tepicht, Lênin e Kautsky, realizaram trabalhos clássicos por suas abordagens e contribuições na compreensão da questão agrária e camponesa em outros países, e, serviram de base teórica fundamental nas análises sobre este tema entre os intelectuais brasileiros.

Dentre os trabalhos que deram relevância à questão camponesa, encontra-se também o livro “A questão agrária e o capitalismo”, de Samir Amin e Kostas Vergopoulos, que buscava debater no plano teórico, dentro da teoria marxista, o papel do pequeno produtor agrário e a necessidade de se mudar o olhar marxista clássico sobre a questão camponesa, sobretudo em países do "Terceiro Mundo". ${ }^{12}$

Na década de 1970, o enfoque teórico nas pesquisas brasileiras se deu, ora sob a perspectiva teórica do campesinato, entendido como uma relação não-capitalista, e ora como pequena produção, por estar estruturada com base no trabalho familiar, mais ligada à produção de subsistência.

Contudo, as análises sobre o campesinato ficavam ainda em um plano secundário nas pesquisas e debates acadêmicos, devido à discussão entre capitalistas e feudalistas que acreditavam na iminente proletarização desta categoria e seu caráter marginal no processo de desenvolvimento brasileiro sendo, portanto, considerados irrelevantes. Os camponeses, conforme observou Martins (1995), não eram incluídos nos debates sobre a questão agrária brasileira nos anos 1950, o que lhes dava pouca visibilidade política e social.

Como mencionei neste trabalho, a década de 1970 se destaca por transformações políticas, econômicas e sociais que vão marcar o processo de desenvolvimento brasileiro. Desta forma, no âmbito acadêmico, os trabalhos se orientavam, quer pela perspectiva teórica do campesinato, quer pela análise da pequena produção, fato devido às mudanças pelas quais passava a agricultura brasileira.

Assim, tinha-se com relação à pequena produção dois enfoques: um, como relação não-capitalista; e outro, como subordinação ao capital.

Com relação ao primeiro enfoque, destacam-se estudos de Oliveira (1976), Martins (1979, 1980), entre outros, nos quais conforme suas análises, as relações capitalistas no campo brasileiro se deram de forma heterogênea. Elas permitiram que formas nãocapitalistas de produção, isto é, o colonato, o pequeno arrendamento, a parceria, a posse, que

${ }^{12}$ Samir Amin e Kostas Vergopoulos. A questão agrária e o capitalismo. (1997) 
não separavam o produtor direto de seus meios de produção, pudessem, através de uma crescente oferta de excedentes para o consumo interno e externo, consolidar definitivamente o padrão urbano-industrial que se hegemonizava, tornando a pequena produção funcional e não oposta à acumulação de capital industrial. Por isso, vastas extensões de terra permaneciam improdutivas.

Somado a esses fatores, o Estado também vai permitir e incentivar a ocupação da fronteira agrícola por parte destes pequenos produtores, para amenizar conflitos pela posse de terra, através da implantação de projetos de colonização, fossem eles oficiais ou privados.

Desta maneira, devido à fragilidade com que a expansão do capital se deu na agricultura brasileira, a pequena produção era vista como forma de produção não capitalista. Para Martins (1975), as formas não capitalistas de produção vão se reproduzindo devido ao próprio desenvolvimento capitalista, quando este transforma a renda da terra, pré-capitalista, em renda capitalista.

Isto se dá, conforme Martins, porque o capital, ao controlar a produção na cidade e no campo, leva o agricultor familiar, mesmo não perdendo a posse da terra, a depender cada vez mais dos setores urbano-industriais, deixando, indiretamente, nessa relação, a renda da terra nestes setores. O que vai ocorrer então, não é a sujeição do trabalho ao capital, mas a sujeição da renda da terra ao capital. Martins (1995, p.171), justifica essa afirmação, ao esclarecer que,

[...] o modo capitalista de produção não se circunscreve à produção; ele é modo de produção e modo de circulação de mercadorias e de troca de mercadoria por dinheiro e de dinheiro por mercadoria. Isso justamente porque não é essencialmente um modo de produção de mercadoria, strictu sensu, mas sim um modo de produção de mais-valia. E a mais-valia não é o produto final do processo de produção, O produto final é a mercadoria que contém mais-valia; essa mais-valia precisa realizar-se e isso só é possível na circulação, quando finalmente o capitalista troca mercadoria concreta por dinheiro, o equivalente geral, que mede e representa o trabalho social [......]. Na produção a mais-valia é produzida e só na circulação ela se realiza. (Grifos do autor).

Nessa relação, vai ocorrer, então, a sujeição da renda da terra ao capital; dessa forma, essas concepções teóricas vão influenciar muitos trabalhos, entre eles os de Oliveira (1986 e 1991). A produção camponesa é vista, assim, como pequena produção que se organiza tendo como base relações de produção não-capitalistas, isto é, assentada na mão-de- 
obra familiar, que produz para sua subsistência e comercializa no mercado apenas o excedente.

Observa-se ainda, outros autores ${ }^{13}$ que, tomando a linha teórica do campesinato, segundo trabalhos clássicos de Shanin, Chayanov, entre outros, deram destaque às especificidades das unidades produtivas camponesas, ou seja, de um lado, analisavam a unidade de produção, e, de outro, a unidade de consumo e as relações que são estabelecidas entre elas. Estes trabalhos, apesar de terem aprofundado o entendimento da estrutura interna do campesinato, receberam críticas, pois, ao destacarem apenas as especificidades deixavam de analisar de forma mais ampla o seu significado teórico e seu conteúdo explicativo.

Já o enfoque da pequena produção subordinada ao capital industrial teve como expoentes pesquisas de Lopes (1977) e Tavares dos Santos (1978), trabalhos que abordaram a crescente articulação entre agricultura e indústria. Outro caminho foi o do Complexo Agroindustrial (CAI), como tratou Guimarães (1979), baseado na modernização conservadora do campo, que, conforme destaca Hespanhol (2000, p.44), se deu pelas seguintes características:

[...]a) decisiva ação do Estado, seja por intermédio das políticas creditícias, implementadas com a criação do Sistema Nacional de Crédito Rural (SNCR) em 1965; pelo incremento das atividades realizadas pelos órgãos oficiais de pesquisa e extensão rural, como a Empresa Brasileira de Pesquisa em Agropecuária (EMBRAPA) e a Empresa Brasileira de Assistência Técnica e Extensão Rural (EMATER); seja na própria organização produtiva de certos setores industriais, como o de fertilizantes; b) processo altamente seletivo e diferenciado em termos espaciais, concentrando-se no Centro-sul do país; de categoria de produtores, privilegiando médios e grandes e de produtos, contemplando os exportáveis e as matérias-primas industriais; c) representou a perda do antigo caráter autônomo da agricultura e da capacidade decisória dos grupos que a compõem; d) determinou uma maior articulação da agricultura com os demais setores da economia, especialmente com o industrial e financeiro.

Devido a essa realidade, estes trabalhos interpretariam ainda as mudanças da pequena produção com relação à inovação tecnológica e as conseqüências dessa aproximação com os setores industriais, fornecedores de equipamentos, insumos químicos e as agroindústrias.

${ }^{13}$ Garcia Junior (1976) e Heredia (1979). 
Esse enfoque levou também à percepção da subordinação formal da pequena produção ao setor industrial, pois, o produtor familiar não decide mais, por exemplo, qual é a extensão a ser plantada, nem o destino da produção apesar de continuar “dono” da terra.

Por outro lado, para os pequenos produtores que não puderam se integrar, ou mesmo participar desta "modernização" do campo, a saída foi migrar, fosse para outras regiões do país, como agricultor nas áreas de fronteira agrícola, ou para a periferia das áreas urbanas, como trabalhador assalariado.

A realidade instigará os estudiosos a reformular os referenciais teóricos que vigoravam com relação ao conceito de unidade produtiva familiar, pois se tinha a percepção da complexidade desse tema.

De toda maneira, os trabalhos sobre a pequena produção na década de 1980 têm que ser analisados em um contexto mais amplo, onde a abertura política, juntamente com a crise financeira do Estado brasileiro levou a uma possibilidade de maior mobilização social, tanto nas cidades quanto no campo.

Algumas abordagens teóricas incidiram, então, sobre as diferenciações que ocorriam entre os produtores e entre as regiões, no setor agrícola brasileiro, devido ao processo de modernização e à atuação do Estado que, neste período, devido à crise, recuava na sua política de subsídios que sustentara, até então, as mudanças tecnológicas no campo.

Assim, a importância dada à pequena produção como solução para a questão agrária, principalmente nos anos 1970, foi então revista nos anos 1980 através de enfoques que a enxergavam como subordinação, através da integração, ou como exclusão social.

Entretanto, trabalhos de Souza (1980), Kageyama (1985), Graziano da Silva (1987), Müller (1988), Abramovay (1992, 1993), entre outros, apontaram para outras facetas deste tema. Entre elas, surge a da redução do papel da pequena produção no processo de desenvolvimento capitalista, devido à perda de seu papel produtivo, face às mudanças no processo de urbanização e às mudanças no padrão alimentar brasileiro; além disso, alguns estudos revelavam que, sob o ponto de vista do valor da produção, o peso da pequena produção era muito baixo, representando pouca importância no nível de salários, como lhe atribuíram os "funcionalistas".

Neste sentido, Souza (1980, p. 94), expõe sua crítica, a meu ver equivocada de que, 
Os camponeses pobres, por seu lado, não conseguem sequer fixar os preços de seus produtos, estabelecidos pelo capital na intermediação e comercialização da produção; seria irônico admitir que sua renda possa servir de base de fixação de coisa alguma na economia, muito menos algo tão complicado como a taxa de salários.

Desta forma, segundo Abramovay (1994), a pequena produção adquiria, sob esta ótica, uma imagem parasitária, ao citar trabalho de Graziano da Silva e colaboradores (1978), entre outros. Kageyama (1985 e 1989/90), por sua vez, estudou, neste período os impactos da modernização da agricultura no emprego e na produtividade, analisando dados dos Censos Agropecuários de 1970 e 1980. Constatou que a mão-de-obra familiar atuava em, aproximadamente, dois terços das ocupações agrícolas, contudo no período analisado os trabalhadores assalariados tiveram taxas de crescimento maiores, o que demonstrava o caráter capitalista dessa agricultura.

Este trabalho também vai destacar a diferenciação que ocorria dentro da categoria de pequeno produtor, quando compara as diferenças entre produtores do sul, do sudeste, do norte e do nordeste do país, o que refletia a intensificação do caráter heterogêneo da produção familiar, ao longo do processo de modernização.

Nessa perspectiva, Graziano da Silva (1983, p. 50), ressalta que,

A questão fundamental no caso brasileiro é que a modernização dos pequenos produtores se deu sob um regime político-institucional caracterizado pelo arbítrio, o qual impediu as suas organizações de exercerem uma postura reivindicativa. Assim a tecnificação apenas garantiu a transferência de maiores excedentes do setor camponês para os capitais industriais e financeiros que o subordinavam. [....] a presença de um setor camponês tecnificado [....] não se traduziu num processo de diferenciação ascendente dessas unidades.

E, com relação às possibilidades de reprodução social desta categoria nas áreas de fronteira agrícola, também ocorreram mudanças, pois o Estado vai priorizar incentivos para as grandes propriedades, aumentando a especulação fundiária nas regiões Norte e Centro - Oeste do Brasil, conforme demonstram trabalhos de Wilkinson (1986) e Calaça (1983).

Importantes também neste período foram os trabalhos de antropólogos, sociólogos, entre outros, que trataram das lutas sociais e políticas das diversas categorias de 
trabalhadores no campo ${ }^{14}$, da constituição de suas “representações” e de suas atuações no cenário político.

A pequena produção passou a ser analisada sob outros enfoques, entendida por alguns como parte do capitalismo, e inserida nele de forma a se adequar aos movimentos do capital; e ressaltavam-se, contudo, críticas à modernização conservadora que levou a uma intensificação dos problemas sociais, regionais e ambientais advindos dela.

De toda maneira, observa-se que os trabalhos que tratam da produção familiar, a partir de então, vão retomar e aprofundar os enfoques teóricos já mencionados, como o perfil diferenciado que a pequena produção assumia frente ao desenvolvimento capitalista e sua viabilidade econômica, enfatizados, por exemplo, em Graziano da Silva (1983), Antuniazi (1987), Nakano (1981) e Moreira (1981).

Encontra-se, em alguns destes trabalhos, destaques para o produtor familiar modernizado; as formas de inserção ou exclusão das unidades familiares de produção; a busca por definir critérios que melhor as definissem, como o valor da produção agropecuária dessas unidades; a participação do capital financeiro na agricultura e suas conseqüências, em Delgado (1985); a identificação de classes e frações sociais neste segmento, em Müller (1981); e, mesmo, a classificação dos estabelecimentos pela composição da força de trabalho aí encontradas, em Kageyama \&Bergamasco (1989/90).

Pode-se destacar, ainda, as análises das relações entre a produção familiar e a indústria, em Sorj, Pompermayer e Coradini (1982); e as estratégias de reprodução dos produtores familiares, em estudos realizados por Wanderley (1985).

Esta autora, ao analisar a permanência do produtor familiar no campo, destacava seu caráter de trabalhador para o capital; entretanto, este trabalhador se distinguia do proletário em três aspectos: 1) o trabalho familiar, dentro da unidade reprodutiva, proporcionava o capital para a compra de terra e para a organização da atividade agrícola; 2) a transferência do sobretrabalho, nos produtos explorados, se dava através da mediação do mercado capitalista; 3) o fato de haver um desenvolvimento da agricultura capitalista não significava que ela se reproduziria de forma homogênea no setor agrícola, pois, se há a subordinação ao capital, ela se dá de forma heterogênea e em diferentes graus.

${ }^{14}$ Martins (1980 e 1981), Medeiros (1989), Grzybowski (1986). 
Uma outra questão que mereceu destaque nos estudos foi a percepção de que o conceito de pequena produção poderia incluir tanto aqueles produtores mais tecnificados, com maior acesso ao capital financeiro, com características de empresas familiares, quanto os mais tradicionais, sem associação com o capital financeiro ${ }^{15}$.

Concordo também, com a posição de que as denominações, agricultura familiar e agricultura camponesa podem ter significados e representações diferentes, dependendo das concepções teóricas e políticas escolhidas pelos estudiosos deste tema ${ }^{16}$.

Conforme Abramovay, seria necessário superar dois preconceitos para que se pudesse compreender, de maneira mais profunda, o campo brasileiro nos anos 1990; neste sentido,

[...] o primeiro é o que assimila, confunde, transforma em sinônimos "agricultura familiar" e expressões como "produção de baixa renda", "pequena produção" ou até mesmo "agricultura de subsistência"; e o segundo é o que considera as grandes extensões territoriais trabalhadas por assalariados como a expressão mais acabada do desenvolvimento agrícola. (ABRAMOVAY, 1997, p.73)

Este autor destaca que perdura ainda a visão de que a agricultura familiar só teria valor social, enquanto o seu caráter econômico seria tido como irrelevante e que conseqüentemente o destino do campo seria o esvaziamento; assim, seria necessário superar este posicionamento.

Neste período, houve também o destaque do papel da produção familiar dentro das propostas de sustentabilidade ambiental, onde uma agricultura sustentável, segundo Blum (1999, p. 75), teria, entre seus pressupostos básicos: a combinação de técnicas modernas, aliadas à prática de conservação do solo e da água, à rotação e à diversificação de culturas; o controle integrado de pragas, doenças e plantas daninhas; a integração lavoura e pecuária ao plantio direto; a geração dos próprios insumos internamente; a substituição dos agroquímicos e combustíveis por recursos encontrados na própria fazenda ou próximo dela, ou seja, a produção familiar daria respaldo à divulgação e à implementação dessas práticas.

Uma outra importante contribuição ao debate foram os estudos comparativos que analisaram a agricultura familiar em nível internacional ${ }^{17}$, ao demonstrarem

\footnotetext{
${ }^{15}$ Cf. Maria José Carneiro, 1999.

${ }^{16}$ Cf. Bernardo Mançano Fernandes, 2002.

${ }^{17}$ Lamarche (1993 e 1997).
} 
como as unidades produtivas familiares estão intimamente ligadas ao desenvolvimento econômico e social de países como a França e o Canadá, entre outros.

Enfatizo que, ao lado das discussões de âmbito acadêmico, deve-se alinhar sempre processos políticos e sociais; assim, processos que ocorreram no final dos anos 1980 e no início dos anos 1990, vão, juntamente com outras questões, colocar a agricultura familiar e a questão agrária brasileira em destaque.

Dentre estes aspectos, pode-se destacar aqueles de âmbito conjuntural, como a onda neoliberal, que levava à constante redução do papel do Estado na economia; os processos de globalização e de regionalização, com a formação de blocos econômicos; e, no âmbito nacional, pode-se ressaltar a pressão de movimentos sociais, com destaque para aqueles que reivindicavam uma política de reforma agrária.

Assim, o tema reforma agrária voltou a ser debatido no governo de José Sarney (1985-1989), quando foi elaborado o I Plano Nacional de Reforma Agrária. Houve, durante a elaboração das propostas, uma grande participação da sociedade organizada, representada, entre outros, pela Ordem dos Advogados do Brasil (OAB), a Associação Brasileira de Reforma Agrária (ABRA), a Confederação dos Bispos do Brasil (CNBB), a Comissão Pastoral da Terra (CPT) e o Conselho Indigenista Missionário (CIM). Contudo, apesar deste engajamento, os avanços foram lentos, embora embrionários de outros, que se seguiriam.

A Constituição de 1988 possibilitou, através das orientações de descentralização político-administrativa, que passava para os municípios atribuições que antes eram de âmbito estadual e federal, que as comunidades participassem mais efetivamente da gestão pública; tal oportunidade contou, por exemplo, com o apoio e participação das Comunidades Eclesiais de Base (CEBs), ligadas à Igreja Católica, que, incentivando movimentos sociais urbanos e rurais, vão ressaltar o importante papel que os grupos familiares tinham nos processos de decisão de suas comunidades.

Na década de 1990, em decorrência da evolução desses processos, as questões relativas à produção familiar emergem ao debate, inclusive através de exigências por políticas diferenciadas para este setor, pois o produtor familiar tinha que disputar recursos creditícios com outras categorias de agricultores; sendo assim, pode-se dizer que, pela primeira vez na história do Brasil, há uma política governamental inteiramente voltada à produção familiar, através do decreto 1.946, de 28 de junho de 1996, que criou o Programa de Fortalecimento da Agricultura Familiar (PRONAF). Mesmo assim, verifica-se que tal política 
ainda está muito aquém das necessidades deste setor. Com relação a estas reivindicações, destacou-se, entre outras, a atuação da Confederação Nacional dos Trabalhadores na Agricultura (CONTAG).

Contudo, Martins (2000), em análise mais aprofundada sobre a questão agrária, destaca que,

Poucos têm notado [...] que o Estado brasileiro, para corrigir erros relativos ao domínio do território e às suas funções na gestão do uso e da ocupação territorial, cometidos pelo Parlamento na elaboração da Lei de terras, de 1850, vem progressivamente, desde a Revolução de Trinta, agindo no sentido de recuperar ao menos parte de seus direitos dominiais. Nessa linha, a ação reformista do atual governo introduz nessa base estrutural da questão fundiária elementos novos, relativos sobretudo à definição e reconhecimento histórico da reforma [agrária], que é a agricultura familiar, uma inflexão na opção histórica preferencial pelo capitalismo rentista e pela política fundiária concentracionista, que vingou até anos recentes ${ }^{18}$.

No âmbito político, verifica-se então que, de um lado, houve pressões por mudanças, como já foi citado, no qual movimentos sociais de trabalhadores agrícolas, que, representados principalmente pelo Movimento dos Trabalhadores Sem Terra (MST), pressionassem o governo e reivindicassem uma reforma agrária ${ }^{19}$, estruturada em unidades produtivas familiares, através dos assentamentos; e, de outro, através dos sindicatos, liderados pela Confederação Nacional dos Trabalhadores na Agricultura (CONTAG), para que houvesse uma ampliação do Programa Nacional para Agricultura Familiar (PRONAF), colocando, definitivamente, esta categoria de produtores na agenda institucional.

Ressalto que apesar das diferentes propostas teóricas e abordagens analíticas aqui destacadas, em um aspecto todas convergem, ou seja, concordam que a produção familiar, tratada de forma ampla, se caracteriza por ser aquela em que a propriedade da terra e o trabalho nela realizado estão intimamente ligados à família.

Após estas considerações acerca de algumas correntes teóricas que refletiram sobre a produção familiar, juntamente com a exposição, em linhas gerais, dos principais aspectos relacionados aos processos institucionais e de reivindicações políticas dos produtores familiares e de setores ligados a eles, passarei a análise do desenvolvimento do capitalismo no campo brasileiro.

\footnotetext{
18 José de Souza Martins, 2000. p.41.

19 Apesar da reconhecida importância do tema "Reforma Agrária”, a mesma será tratada aqui como um referencial, por não se tratar do objetivo principal desta pesquisa. Cf. Revista Reforma Agrária, entre outros.
} 


\section{CAPÍTULO 3 - O DESENVOLVIMENTO DO CAPITALISMO NO CAMPO BRASILEIRO}

O desenvolvimento do capitalismo no campo brasileiro envolve posições e debates apaixonados por parte daqueles que buscam compreendê-lo; desta maneira, buscarei destacar algumas correntes de pensamento teórico que analisam o desenvolvimento do capitalismo no campo brasileiro.

Entre aqueles que desenvolveram uma interpretação do Brasil, distinguemse trabalhos de Caio Prado Júnior (1942, 1943, 1966, 1979), que ressaltam o processo da formação econômica brasileira, desde o período colonial, fundado na produção extensiva para mercados do exterior, baseado em um regime agrário de grandes propriedades. Entendia ele que o Brasil, desde sua condição como colônia, já fazia parte de um sistema capitalista mercantil plenamente globalizado, sistema dinâmico, em transformação, e asseverava sobre a economia brasileira naquele período onde, o que se destaca e lhe serve de característica fundamental é: de um lado, na
sua estrutura, um organismo meramente produtor, e constituído só para
isso: um pequeno número de empresários e dirigentes que senhoreiam tudo,
e a grande massa da população que lhe serve de mão-de-obra. Doutro lado,
no funcionamento, um fornecedor do comércio internacional dos gêneros
que este reclama e de que ela dispõe. Finalmente na sua evolução, e como
conseqüência daquelas feições, a exploração extensiva e simplesmente
especuladora, instável no tempo e no espaço dos recursos naturais do país.
(PRADO JÚNIOR, 2000, p. 127)

Entretanto, apontava ele que, ao lado da grande lavoura, voltada para a exportação, que empregava mão-de-obra numerosa e organização coletiva do trabalho, havia a agricultura de "subsistência”, onde predominavam tipos variáveis de estrutura agrária. Contudo, a ênfase de suas análises, baseadas na interpretação marxista, sobre a formação econômica do país, o faz colocar as relações sociais de produção como ponto principal, sendo que estas relações serão determinantes nas características da economia. Observava, ainda, que o problema na economia agrária brasileira não estava na estrutura fundiária e, sim, nas relações de emprego e condições de trabalho contraditórias. 
Outras obras importantes nessa área são as de Alberto Passos Guimarães (1964, 1979), nas quais aponta, em análises nos anos 1960 e 70, dentro de uma visão mais ampla que,

nesta atual fase do crescimento agrícola, que se destaca pelo mais amplo e mais rápido desenvolvimento da economia mundial - na qual a superacumulação e a centralização de capitais atingem a maior intensidade as atividades econômicas se concentram em gigantescas unidades empresariais, e é cada vez maior, no mundo capitalista o domínio exercido pelos conglomerados financeiros, pelos monopólios e corporações multinacionais. A atividade agrícola depois de tanto tempo separada da indústria, vai pouco a pouco voltando-se a ligar a esta, direta ou indiretamente, vertical ou horizontalmente, integrando-se subordinando-se ao poder econômico dominante na sociedade capitalista industrial. (p.14, 1979)

Ele continua a destacar que a formação do complexo agroindustrial no Brasil, bem como em outros países menos desenvolvidos, fez com que a agricultura desses países fosse um setor produtivo subordinado às empresas multinacionais, e que, por causa da influência de poderosas corporações, a estratégia de desenvolvimento rural, que era centrada nas políticas de reforma agrária, passa a ter outro centro de gravidade, representada pela implantação de grandes empresas rurais “modernizadas” sem, contudo, haver mudanças mais profundas nas relações de trabalho, no emprego da mão-de-obra, na distribuição de terras e, além disso, utilizando tecnologia sofisticada e cara, o que limitava o acesso a maioria dos produtores rurais.

Assim, na medida em que se industrializava, a agricultura foi perdendo sua autonomia e poder de decisão; a produção, sem dúvida, aumentava e também seus custos, e a lucratividade não era assim compensada, pois os produtos se tornaram menos competitivos e tenderiam a ser dominados por condições monopolísticas.

Com relação à fragmentação e à concentração da propriedade privada da terra, Guimarães (op.cit.) destacava que a irracionalidade das estruturas prejudicava muito a exploração agrícola, pois grandes explorações ao lado de pequenas possuem níveis de produtividade e lucratividade muito diferentes com relação à intensidade de trabalho e ou de capital empregados. Ele propunha, assim, que países como o nosso devessem, via Estado, promover a redistribuição da terra e dos meios de produção.

Reconhece, entretanto, que a problemática com relação à estrutura fundiária é complexa, e cita a obra clássica de Kautsky (1986), que trata a questão dos limites da 
exploração capitalista, isto é, tanto sua superioridade quanto suas limitações; e, com relação à convivência da pequena e da grande empresa na agricultura capitalista salienta que elas não se excluem, mas, sim, se apóiam; contudo, o pequeno camponês tem aí, segundo ele, o caráter de proletário.

Graziano da Silva (p.137,1994) também aponta para a rápida e profunda transformação ocorrida nos últimos 40 anos na agricultura brasileira, ou seja, a evolução dos complexos rurais - grandes propriedades que tinham nível de consumo interno e produção de subsistência interna na propriedade -, para o que ele chama de complexos agroindustriais, conceito este discutido de forma ampla no livro "A nova dinâmica da agricultura brasileira” (1996).

Ainda segundo Graziano da Silva (in: Delgado et al.,1990), o setor agrícola passou de setor autônomo da economia, convencionado de "modernização conservadora”, a setor altamente integrado, pois, após 1964, consolidaram-se em “complexos agroindustriais”, sendo que, em meados de 1970, já não é mais possível analisar-se a agricultura brasileira como uma unidade.

Esse autor ressalta duas características fundamentais nesse desenvolvimento, um processo profundamente desigual e excludente, em que a modernização foi um processo brutal de concentração da produção, da concentração de renda, e, ao mesmo tempo, da concentração da miséria.

Quando trata da industrialização e da urbanização da agricultura brasileira, ele destaca que o espaço rural brasileiro não se reduz mais apenas a sua dimensão agrícola e ou agrária, pois as atividades produtivas tradicionais não conseguem dar conta de explicar a dinâmica do emprego e da população rural do país, já que

é preciso incluir outras variáveis, como as atividades rurais não agrícolas decorrentes da crescente urbanização do meio rural (moradia, turismo, lazer e outros serviços), as atividades de preservação do meio ambiente, além de um conjunto de pequenos negócios agropecuários intensivos (piscicultura, horticultura, flores, fruticultura de mesa, criação de pequenos animais, tipo rã, canários e aves exóticas, plantas ornamentais, etc.) que buscam "nichos de mercado" muito específicos para sua inserção econômica. (GRAZIANO DA SILVA, p. 2, 1996)

A despeito do enfoque de Graziano da Silva, aponto que apesar das mudanças no campo brasileiro terem sido significativas, continua existindo um número de pequenos produtores familiares, cujo número total do pessoal ocupado, segundo os Censos 
Agropecuários da FIBGE de 1975, 1985 e 1995/6, tem apresentado variações de, respectivamente, 17 milhões para 18,5 milhões e 15,5 milhões. Não obstante observar-se uma diminuição nesses números, ainda há um número considerável de produtores que têm no trabalho e na produção agropecuária sua oportunidade de reprodução social .

Cabe salientar, também, que os dados sobre a produção agropecuária, conforme o Censo Agropecuário de 1985, demonstraram que as unidades de área inferior a 100 ha respondiam por mais de $48 \%$ do valor da produção animal e vegetal do país, e, contraditoriamente, representam apenas $21 \%$ da área ocupada total.

Os dados do Censo Agropecuário 1995/6, segundo nossas análises, revelaram que há 4,1 milhões de núcleos de agricultura familiar, representando 85,5\% do total de estabelecimentos, ocupando 30,5\% da área cultivada e representando 38\% da produção agrícola nacional.

Assim, existem no campo brasileiro aqueles produtores cuja produção agrícola já está integrada à indústria e, ao mesmo tempo aqueles produtores cuja produção é, na maioria das vezes, voltada diretamente ao mercado.

Frente a estes fatos, as questões que coloco são: O que tem sido feito para integrar, tanto no aspecto social quanto no econômico, esse pequeno produtor cuja participação na produção e na reprodução social é de reconhecida importância? Como ele tem acompanhado as mudanças técnicas e incorporado tecnologias? E como esse grupo tem participado do acesso aos recursos creditícios e de comercialização? Quais têm sido as formas de representação social deste grupo?

Para Oliveira, em textos de 1982 e 1994 (p.46, 1994), entre outros, o entendimento do campo brasileiro nas últimas décadas, tanto do ponto de vista da posse da terra quanto do que e como se produz no campo, passa pela compreensão da internacionalização da economia brasileira. E esse processo, no âmago do capitalismo mundializado, leva à compreensão do mecanismo da dívida externa, pois a expansão cada vez maior das culturas de produtos de exportação e as mudanças de hábitos alimentares em face da expansão destes produtos, além de ter provocado também o movimento de concentração da população nas cidades, visa atender às necessidades do equilíbrio das contas externas do país.

Assim, para esse autor, o processo de desenvolvimento do capitalismo na agricultura está intimamente relacionado a sua industrialização, a qual deve ser pensada internacionalmente, já que as alianças e fusões entre indústrias nacionais e internacionais são 
fato conhecido, sendo que o Estado participou e/ou permitiu tais alianças e fusões, tanto nos governos militares quanto nos civis.

Ele também acrescenta em suas análises (1981) que, o que ocorreu neste processo de reprodução capitalista ampliada do capital foi a intensificação da apropriação da renda da terra pelo capital, tanto na pequena como na grande propriedade.

Na pequena propriedade, o capital monopolizou o território, ou seja, a indústria subordinou ou se apropriou da renda de terra produzida pelos camponeses, transformando-a em capital através, por exemplo, da integração na avicultura e na suinocultura no Sul do Brasil; e na grande propriedade, através da garantia da propriedade e da posse da terra, que, segundo o autor, possibilitaria aos proprietários de terras e aos capitalistas / proprietários de terras o lucro de seus empreendimentos e da renda da terra, territorializando o capital.

Oliveira destaca ainda em suas análises, a questão da estrutura fundiária brasileira e seu caráter concentrador, ao lado do crescimento do campesinato brasileiro, que tem tido a característica de querer a terra e lutar para entrar nela, como já tratou José de Souza Martins (1979, 1980).

Ele aponta como tendência para o futuro que,

os agricultores capitalistas continuarão a produzir apenas aqueles produtos que lhes permitirão obter lucros certos nos mercados externos e internos. Os agricultores camponeses por sua vez, têm sido pressionados no rumo da especialização. Muitos autores progressistas têm apontado as cooperativas e a especialização como a alternativa aos camponeses que chegam à terra. (p.49, 1994)

e, a meu ver, para aqueles que já estão, a possibilidade de permanência nela.

Segundo meu ponto de vista, talvez esta possa ser uma possível solução para os agricultores familiares. Entretanto, para que as cooperativas, as associações e a especialização possam ser efetivadas, muitos arranjos devem ser feitos, pois, tão importante quanto querer terra, e poder entrar nela é poder mantê-la produtiva, tendo como financiar a produção, ter a segurança do preço pago pelo produzido, e poder comercializar essa produção, de maneira a obter rendimentos que possibilitem novos investimentos em sua área agrícola; e, enfim, provocar mudanças nas questões de gerenciamento da produção e da comercialização. 
Um outro enfoque de análise sobre as transformações do campo brasileiro é o de Muller. Este economista faz um esquema da organização agrária brasileira predominante em fases de nossa história. Desta forma, destaca que no período de 1870-1940,

as ligações entre os setores agrário e industrial ocorriam através da comunicação (trem e navegação) e do comércio [...] O avanço interno das fronteiras e o comércio internacional de bens agrários eram os mecanismos pelos quais as economias nacionais e internacionais supriam suas demandas por alimentos e matérias- primas . (1994, p. 10)

O período seguinte vai de 1940-1980, quando as ligações do setor agrário e o industrial ocorreram nas conexões entre os diversos setores da economia nacional e também da internacional; foi onde se deu a chamada "industrialização do campo". Segundo esse autor, esse termo designa as relações entre as indústrias que encontravam demanda na agricultura, de um lado e, de outro, a "agroindustrialização", ou seja, a "tendência da produção agrária ser beneficiada e transformada, e destinada a grandes centrais de abastecimento urbano e supermercados, bem como destinada ao comércio exterior”. Acrescenta ainda que esta agroindustrialização não significou transformar somente a produção, mas provocou, também, a modernização tecno-econômica dos setores de beneficiamento, transporte e marketing.

Desta maneira, segundo essa análise, as atividades agrárias passam a ser consideradas mais um setor econômico no conjunto das atividades industriais, comerciais e de serviços, e, ainda, são integradas em diversos níveis, isto é, local ou nacional, regional ou internacional. É importante ressaltar que esta nova organização do capitalismo no campo brasileiro, não ocorreu somente pelas forças do mercado e sem resistência, mas observaramse, nos anos 1950-60, conflitos e reivindicações pela reforma agrária, que foram abafados pelos governos militares que se seguiram.

Assim, conforme Muller (op.cit.), esta organização agrária que apresentava uma estrutura produtiva e distributiva diferente, provocou a exclusão social e econômica da maioria dos produtores e trabalhadores, que, atraídos pelos núcleos urbanos, foram incorporados à dinâmica dos novos negócios agrários somente como trabalhadores assalariados e como demanda por mão-de-obra nos ciclos produtivos agrícolas.

Em “De Camponeses a Agricultores - Paradigmas do Capitalismo Agrário em Questão”, Abramovay (1990), trata da relação entre o desenvolvimento do capitalismo no campo e a agricultura familiar, ressaltando a importância desta agricultura no progresso técnico no campo. 
Ele destaca que as políticas agrícolas "foram a condição para que a agricultura desempenhasse um papel fundamental no próprio desenvolvimento do mundo capitalista” (p. vi, 1990), em países de capitalismo avançado; e, no caso brasileiro, o capitalismo é desarticulado, pois a "dinâmica de seu crescimento vem ou das exportações ou do consumo de parte minoritária da sociedade, o problema social da concentração da renda adquire uma dimensão econômica crucial.” (p.327); e aponta ainda que, uma mudança na dinâmica social, provocaria uma dinâmica econômica similar à ocorrida nos países capitalistas centrais.

Desta forma, para esse autor, tão importante quanto estudar o desenvolvimento do capitalismo no campo seria o aprofundamento da contribuição que a agricultura pode dar a um padrão de desenvolvimento capitalista, em que os ganhos do trabalho sejam um elemento central do crescimento econômico.

Pode-se então observar que, para Prado Júnior, a questão principal é a regularização econômica e jurídica dos vários tipos de ocupação e das relações de trabalho na agricultura; já Guimarães aponta a redistribuição de terras e, em viés mais radical, a inviabilidade da agricultura capitalista no Brasil.

Graziano da Silva (p.139-140, 1994), indica que três tendências são importantes para se compreender o capitalismo no campo brasileiro: a crescente integração dos capitais na constituição dos complexos agroindustriais, a redução do papel da pequena produção nesse processo de desenvolvimento capitalista e a redução da sazonalidade do trabalho.

Para Oliveira (p.24-51,1994), a questão principal é que o processo de desenvolvimento do modo capitalista de produção no território é contraditório e combinado, ou seja, este desenvolvimento avança reproduzindo relações especificamente capitalistas (com o trabalho assalariado), assim como produz, simultaneamente, relações camponesas de produção (com o aumento do trabalho familiar no campo). Ele destaca ainda a importância do produtor rural camponês na produção de produtos básicos da população e de várias matériasprimas industriais.

Nos trabalhos de Muller, contudo, o destaque estava na perda da importância da própria agricultura e a sua substituição pelo complexo agroindustrial como unidade analítica fundamental; e, com relação a suas análises sobre a industrialização da agricultura, a ênfase se dava nas mudanças da base técnica e nos destinos dos produtos. 
Para Abramovay, a questão é se a atual estrutura produtiva do capitalismo agrário brasileiro poderá trazer mudanças no rebaixamento durável de preços alimentares, “ou se, para levar adiante uma política durável de redistribuição de renda, o próprio padrão de crescimento na agricultura terá que ser modificado”. (p.329)

Gostaria de ressaltar que nessa exposição sobre o pensamento destes autores muitas contribuições não foram consideradas; entretanto, tentei expor, de forma geral quais são suas linhas mestras de análise.

Nota-se assim que cada intelectual citado neste capítulo, que aborda as questões que envolvem o desenvolvimento do capitalismo no campo brasileiro, segue linhas teóricas diversas; contudo, eles concordam em um ponto: o aumento das diferenças e dos problemas sociais e econômicos advindos dele.

Desta forma, ao me posicionar frente à questão do desenvolvimento do capitalismo no campo brasileiro, concordo com os estudiosos citados de que houve, para uma grande maioria, um aprofundamento das desigualdades tanto sociais quanto econômicas, e que todos os pontos analisados são fundamentais para o estudo deste assunto. Mas, é preciso, contudo, um esforço intelectual para ajustar a realidade às teorias propostas e não o inverso. Muitas vezes, a realidade, ao ser analisada pelos teóricos, tem deixado de lado aspectos importantes de análise, pois a produção familiar no campo brasileiro não se dá de forma homogênea.

Neste contexto, este trabalho quer destacar a importância da agricultura familiar para o avanço social e econômico da região de Presidente Prudente, em particular, assim como do restante do país; e ao não inseri-la em uma análise mais ampla que inclua também o particular, é desconhecer a realidade. Reconheço que ela é multifacetada em um país com as dimensões do Brasil; contudo, é preciso muita pesquisa e reflexão antes de se fazer certas afirmações, pois o Brasil rural / agrário ultrapassa muito as estatísticas oficiais, fontes, às vezes únicas, de diversos trabalhos. 


\subsection{AGRICULTURA BRASILEIRA NAS DÉCADAS DE 1980 E DE 1990 - ASPECTOS FUNDIÁRIOS, ECONÔMICOS E POLÍTICOS}

Apresentarei, a seguir, alguns dados sobre a situação da agricultura brasileira nas últimas décadas do século XX.

Com relação à estrutura fundiária, segundo o Censo Agropecuário (1985), os estabelecimentos de até 10 ha (que chamaremos de minifúndios) somavam 3,064,822 unidades com área total de apenas 10 milhões de hectares e os estabelecimentos 10 a 100 ha somavam 2,160,340 estabelecimentos, ocupando um total de 70 milhões de hectares. Estes estabelecimentos, considerados pequenos são, na maioria, explorações familiares, responsáveis principais pelo abastecimento de gêneros alimentícios para o mercado interno.

TABELA 2. BRASIL - ESTRUTURA FUNDIÁRIA (1985)

\begin{tabular}{|l|c|c|c|c|c|c|c|}
\hline \multirow{2}{*}{ Área } & \multicolumn{2}{|c|}{ Pessoal ocupado } & \multicolumn{2}{c|}{ Área total } & \multicolumn{2}{c|}{ Número de propriedades } & $\begin{array}{c}\text { Participação na } \\
\text { produção }\end{array}$ \\
\cline { 2 - 8 } & pessoal & $\%$ & ha & $\%$ & & $\%$ \\
\hline em valor \\
\hline 100 a 500 há & $1,030,869$ & $4.72 \%$ & $90,601,489$ & 24.08 & 473,841 & 8.14 & $54 \%$ \\
\hline mais de 500 há & 427,658 & $1.96 \%$ & $205,976,368$ & 54.74 & 94,882 & 1.63 & $13 \%$ \\
\hline Total & $21,863,571$ & 100.00 & $376,286,575$ & 100.00 & $5,820,988$ & 100.00 & $100 \%$ \\
\hline
\end{tabular}

Fonte: Censo Agrícola - FIBGE. 1985

Os estabelecimentos de menos de 100 ha, segundo o Censo Agropecuário de 1985, apresentavam uma produtividade de 2.5 vezes a média nacional por hectare. Os estabelecimentos de 100 a 500 ha e aqueles considerados grandes latifúndios, com mais de 500 ha, se dedicam principalmente à pecuária de corte, culturas de exportação e produção de açúcar e álcool. A produtividade por hectare nas propriedades de 100 a 500 ha é de 1.4 vezes a média; entretanto, a produtividade dos latifúndios é baixa, ou seja, representa $24 \%$ da média nacional. 
Da área total declarada no cadastro do INCRA em 1992, cerca de 62.4\% estavam classificadas como improdutiva e, 23.3\%, como produtivas. Os minifúndios e áreas não classificadas representam 14.3\%.

A região Norte é a que apresenta maior percentual de imóveis classificados como improdutivos sobre a área declarada (78\%), seguida pela região Nordeste (70\%), a Centro-Oeste (63\%), a Sudeste (50\%) e a Sul (43\%).

Em 1996, existiam cerca de sete milhões de estabelecimentos agrícolas, sendo que 4 milhões com menos de 10 ha, 2.4 milhões de 10 a 100 ha e 600 mil com mais de 100 ha.

Ressalta-se que a concentração fundiária do país, medida pelo índice de Gini, está entre as maiores do mundo; na escala que vai de 0 a 1, a média brasileira está acima de 0.8 , desde a década de 1940 !

TABELA 3. BRASIL - ESTRUTURA FUNDIÁRIA (1995/96)

\begin{tabular}{|c|c|c|}
\hline $\begin{array}{c}\text { CLASSE DE ÁREA } \\
\text { (HÁ) }\end{array}$ & $\begin{array}{c}\text { \% NÚMERO DE } \\
\text { IMÓVEIS }\end{array}$ & \% ÁREA \\
\hline$<10$ & 32 & 1,3 \\
\hline $10<100$ & 54 & 16,4 \\
\hline $100<1000$ & 12,7 & 32,1 \\
\hline $1000<10.000$ & 1,2 & 30,3 \\
\hline$>10.000$ & 0,1 & 19,9 \\
\hline Total & $100 \%$ & $100 \%$ \\
\hline
\end{tabular}

Fonte: Sistema Nacional de Cadastro Rural do INCRA. (1996)

O Programa Nacional de Reforma Agrária, segundo dados do INCRA, assentou 94,026 famílias entre 1985 e 1991, compreendendo uma área de 4,713,910 ha (1\% da área agrícola), que responde por $0.8 \%$ da produção total de grãos.

Segundo estimativa do mesmo órgão, publicada na Folha de São Paulo “o governo FHC assentou 80 mil famílias em média por ano, contra 10 mil de média antes de 1994. Para este ano (2000) e o próximo (2001), o INCRA espera assentar 100 mil famílias” (Jornal FSP, A-11, 22/5/00), embora grupos ligados a movimentos sociais no campo, como o 
MST (Movimento dos Trabalhadores Rurais Sem Terra), contestem estes dados e o próprio INCRA não disponha de dados confiáveis sobre os assentamentos ${ }^{20}$.

Com relação às cooperativas, elas podem ser consideradas organizações importantes na estrutura agropecuária brasileira, representando associações de pequenos produtores que realizam várias transações, entre elas a compra de insumos e a comercialização da produção de maneira conjunta.

Conforme dados da Organização das Cooperativas Brasileiras (OCB), existiam, em 1998, 1,388 cooperativas agrícolas, responsáveis por 30\% da produção brasileira. Devido aos obstáculos para a obtenção de crédito nos bancos houve um rápido crescimento de cooperativas de crédito que, em 1998, somavam 859 unidades, e eles destacam que apenas 20\% dos agricultores têm acesso ao crédito oficial do governo.

Entretanto, vem ocorrendo um processo de redução tanto das cooperativas de comercialização quanto das de crédito, o que tem resultado na diminuição das unidades em atividade.

De maneira geral, nos países desenvolvidos, a participação da agricultura no PIB e no emprego diminui à medida que a renda de um país cresce. Neles, observa-se que somente 3\% da população acima de 15 anos encontram-se neste setor. Contudo, segundo o Relatório do Desenvolvimento Mundial (1995), este número é de 44\% para o conjunto dos países de renda mais baixa; o mesmo observa-se com relação à participação da agricultura no PIB.

Ao comparar-se as economias mais avançadas da América Latina, nota-se que a participação no PIB, conforme o mesmo relatório, era, em 1993 de 6\% na Argentina, 11\% no Brasil e 8\% no México; e, nas economias com renda per capita mais baixas, como a da Guatemala e a do Paraguai, essa participação era de, respectivamente, 25\% e 26\%.

No Brasil, conforme a Folha de São Paulo (B-8, 11/6/00), embora a participação do setor agrícola no PIB esteja diminuindo - em 1960, 18\%, em 1970, 12\%, em 1980, 10\%, em 2000, estava em torno de $8 \%$ e $10 \%$ - a renda do setor não tem aumentado; pelo contrário, a inadimplência do setor é alarmante. De acordo com a CNA (Confederação

\footnotetext{
20 "Quase metade dos recursos anuais que serviriam para viabilizar a reforma agrária não chega às famílias assentadas e aos micro e pequenos produtores rurais, o que leva muitos a deixar suas propriedades" cf. Jornal Folha de São Paulo, 27 de abril de 2002, p. A6.
} 
Nacional da Agricultura), em 1994, a inadimplência girava em torno de 18\%; já em 1999 avançou para 46\%, devido à queda da renda gerada pela agricultura brasileira.

Pode-se afirmar que, dentre todos os setores econômicos, a agricultura é o setor cujos agentes têm menor controle sobre as condições do mercado. Isto se dá pela extrema fragmentação da oferta; contudo, ela pode ser também influenciada por fatores climáticos (chuvas, geadas, secas), biológicos (pragas e doenças) e edáficos (topografia e fertilidade).

Assim, a maioria dos governos do mundo tem uma política agrícola que visa atenuar a extrema variabilidade que isto acarreta para a rentabilidade da agricultura, que garanta o abastecimento interno, que apóie tanto as lavouras de exportação quanto as de pequena produção familiar, na tentativa de resolver os problemas sociais daqueles pequenos produtores crescentemente destituídos de suas propriedades.

A Política Agrícola Comum (PAC), da União Européia, formalizada em 1962, surgiu devido à

necessidade de robustecer o sector primário europeu e de traçar um enquadramento econômico e social favorável e estimulante para a população agrícola, impunha a superação das divergências políticas e econômicas entre os Estados membros. (AZEVEDO, 1996, p. XII).

Esta política, segundo Jank,

teve por objetivo aumentar a produtividade da agricultura européia através do desenvolvimento racional do progresso técnico, assegurar um nível de vida eqüitativo para a população rural do bloco, estabilizar os mercados agrícolas e de alimentos, garantir a segurança alimentar e assegurar preços razoáveis aos consumidores. A auto-suficiência alimentar, por exemplo, foi obtida através de uma política draconiana de preços artificiais garantidos no nível da Comunidade. A PAC baseia-se no chamado Mercado Comum Agrícola, que garante a unicidade do mercado (livre circulação de produtos agropecuários e alimentos intra-bloco), a preferência comunitária (mecanismos de subsídios diretos à exportação e de taxação sobre importações) e solidariedade financeira (criação do Fundo Europeu de Orientação e Garantia da Agricultura, o FEOGA). (p. 8, 1999)

Assim, a PAC consome atualmente cerca de metade do orçamento da União Européia (Bruxelas), o que representa mais de U\$ 40 bilhões anuais em subsídios diretos aos agricultores e cerca de U\$ 70 bilhões em subsídios indiretos (via preços garantidos, pagos pelos consumidores). 
A Política Agrícola Norte Americana embora tenha forte orientação liberal também utiliza práticas protecionistas e tem como prioridade a agricultura familiar. Veiga (1994, p.85), destaca a importância deste setor, apontando a Lei Agrícola de 1977 que “não só volta a venerar as virtudes da agricultura familiar como passa a rejeitar outras formas de produção". 21

No caso brasileiro, a política agrária teve um cenário bem diferente. Durante muitos anos, a base da política agrícola ${ }^{22}$ foi o Sistema Nacional de Crédito Rural, formado por aplicações compulsórias dos bancos comerciais e recursos oficiais, que subsidiava os produtores através de empréstimos a juros reais negativos.

Entretanto, tal política não teve o resultado esperado, pois os maiores latifúndios (acima de 10,000 ha), por terem a característica de oferecerem garantias mais sólidas, foram os que receberam a maior parte dos financiamentos disponíveis (75\% em 1980) mesmo representando pouco mais de $1 \%$ da produção em valor; além disso, na maioria das vezes, eles não usaram os empréstimos captados na própria atividade, mas os desviaram para aplicações mais rentáveis ou para a compra de mais terras, o que agravou o problema da concentração, utilizando-as como reserva de valor.

Assim, alguns economistas apontam que uma das origens da crise na agricultura se deu pelos desdobramentos da ruptura do padrão de financiamento da economia brasileira que vigorou até a década de 1970, quando os subsídios agrícolas foram apontados como os causadores dos déficits das contas públicas. Desta maneira, foram implementadas mudanças que levaram à diminuição dos recursos destinados à agricultura.

Ainda segundo Jank (1999), os recursos destinados ao crédito rural no período entre 1975 e 1979 tiveram uma média anual de cerca de US\$ 19 bilhões; em período mais recente, estão em US\$ 4 bilhões / ano. Já os subsídios no crédito, que somavam, entre 1970 e 1985, em torno de US\$ 31,5 bilhões, desde 1985 desapareceram.

Verificou-se então, a partir da safra de 1986/ 87, uma maior ênfase por parte do governo à política de Preços Mínimos de Garantia, cujo compromisso era pagar a diferença entre o preço de mercado e o de garantia, possibilitando um mínimo de rentabilidade.

\footnotetext{
${ }^{21}$ Para um maior aprofundamento das políticas públicas americanas para o setor agrícola, ver Pinazza (1999).

${ }^{22}$ Tratamos com maior profundidade sobre Políticas Públicas para a agricultura no capítulo 4.
} 
O crédito agrícola passou a ser oferecido a taxas reais positivas, embora fossem inferiores às do mercado, ou seja, em 1993/94, 6\% a.a. para mini-produtores com renda até US\$ 5,200/ano; 9\% a.a. para pequenos produtores com renda até US\$ 15,600/ano e $12.5 \%$ a.a. para médios e grandes produtores. Este crédito agrícola era dimensionado através do adiantamento de um percentual dos Valores Básicos de Custeio - VBC; com isso, os pequenos produtores, aparentemente, passaram a ter mais prioridade, em contrapartida à limitação do acesso dos médios e grandes produtores ao crédito oficial.

Mas, na realidade, a prática foi outra pois, segundo artigo da Revista Globo Rural (Julho, 2000, p.54), “60\% do crédito rural ficam com 4 mil grandes propriedades e a agricultura familiar com apenas $25 \%$ do financiamento total, embora empregue $77 \%$ dos 17,3 milhões de brasileiros ocupados no campo”.

Pode-se afirmar que, com essas iniciativas, os problemas do setor agropecuário se agravaram ainda mais. Em tal conjuntura, o que se observou foi o endividamento crescente do setor agropecuário, principalmente entre médios e pequenos produtores, acompanhado pelo descaso do governo na busca por outras soluções.

Desta forma, o Censo Agropecuário do IBGE -1995/6, mostrou que houve a extinção de 940 mil estabelecimentos agrícolas desde 1985, sendo 94\% deles com áreas inferiores a 100 ha, dos quais 73\% até 10 ha.

Foram principalmente aqueles estabelecimentos dirigidos por parceiros, arrendatários e posseiros, pois, concomitantemente ao problema de crédito, a emergência, na década de 1980, de movimentos sociais que pressionam pela reforma agrária, levou proprietários de terra a estabelecer cada vez menos relações de produção como essas.

Como conseqüência, ocorreu também, respectivamente, a redução da área plantada no Brasil, pois, segundo o Censo Agropecuário de 1995/6, 21,3 milhões de hectares deixaram de ser cultivados entre 1985 e 1996; e a diminuição do número do pessoal ocupado na atividade agrícola, no mesmo período, foi de 5,5 milhões trabalhadores.

Por outro lado, os preços das terras agrícolas caíram pela metade na última década do século XX, segundo pesquisa do Centro de Estudos Agrícolas da Fundação Getúlio Vargas - FGV, devido à crise da agricultura, e, com o conseqüente endividamento dos produtores rurais e a estabilização da economia após o Plano Real, podemos afirmar que, com a estabilização da economia, a terra perdeu, em termos, sua função de reserva de valor; assim, 
as terras de pastagens tiveram uma desvalorização de 60,8\%, entre 1990 e 1999; e, as de lavoura, 50,3\%, segundo este levantamento.

A política de liberalização da agricultura se aprofundou mais ainda no atual governo, caminhando em sentido contrário ao dos países mais ricos, que protegem o setor agrícola com subsídios Em 1998, considerando-se todos os subsídios federais, os Estados Unidos liberaram US\$ 12,9 bilhões para socorrer o setor agrícola e, com relação á União Européia (UE) em 1999, os subsídios giraram em torno de US\$ 35 bilhões, conforme Pinazza. (p.32, 1999)

Observa-se, então, por um lado, uma política agrícola que privilegia as importações agrícolas, pois a média anual de importações do setor, que era de US\$ 3 bilhões no período de 1991/94, aumentou para US\$ 6,8 bilhões, na média de 1995/99, provocando, internamente, a queda de preços agrícolas e, de outro, a crescente concentração de terra e de renda.

Segundo estimativas da CNA (Confederação Nacional da Agricultura), no período de 1995/99 foram transferidos R \$24,5 bilhões do setor agrícola para os setores urbanos, e a renda agrícola também caiu, em preços reais, renda esta medida pelo conceito de valor bruto da produção, de R\$ 78,3 bilhões, em 1994, para R\$ 72,4 bilhões, em 1999.

Com relação à renda no campo, o trabalhador rural tem ficado mais pobre, pois, segundo análise do jornal Folha de São Paulo,

a partir de dados de pesquisa coordenada por Angela Jorge Corrêa, da Universidade Metodista de Piracicaba, a renda média das pessoas ocupadas na agricultura permaneceu praticamente estável em 1998 quando comparada a 1981- aumentou, em termos reais, 0,7\%. (FSP- A11, 22/5/00)

A situação da agricultura brasileira, a partir do governo FHC, encontra-se enfraquecida em sua capacidade produtiva, fruto de uma política agrícola e agrária negativa e socialmente excludente. Isso provocou a migração rural-urbana de cerca de 4 milhões de pessoas, entre 1995 e 1999. Ainda assim, o governo FHC comemora o assentamento, em projetos de reforma agrária, no mesmo período, de 1,8 milhões de pessoas.

Desta forma, observa-se que a agricultura brasileira se encontra diante de um quadro de crise onde faltam investimentos, políticas públicas agrícolas e agrárias que a apóiem, bem como a ausência de instrumentos que pudessem gerir novas oportunidades de expansão e / ou reconversão produtiva para o maior número possível de produtores, tanto 
aqueles que se encontravam em graus intermediários de modernização, quando foram atropelados pelo padrão de política agrícola adotado a partir do governo militar, quanto aqueles que têm sido reconduzidos à terra através de lutas sociais pela reforma agrária.

No entanto, a despeito dessa realidade, o produtor familiar é responsável, conforme dados recentes, por cerca de 4,2 milhões de propriedades no Brasil, emprega 14 milhões de pessoas e ocupa 77\% da mão-de-obra rural. A produção agropecuária desse setor responde, segundo o Jornal Folha de São Paulo (A-6, 17/02/03), por 38\% da produção agrícola e metade dos produtos que compõem a cesta básica.

O cenário que se apresenta até aqui na agricultura brasileira não consegue, contudo, escamotear a profunda herança colonial de nosso sistema agrário, que se mostra pouquíssimo alterado em suas bases, isto é, a concentração da propriedade da terra e de renda.

Conforme Linhares (2002), em dados fornecidos pelo Movimento dos Trabalhadores Rurais Sem Terra e pela Pastoral da Terra,

No Brasil, quinhentas famílias detêm $43 \%$ das terras agrícolas e correspondem a três por cento da população rural. Em contrapartida, 57\% da população rural dispõem de três por cento das terras; em 1995, registraramse 409 conflitos agrários, com 41 assassinatos entre os 318 mil trabalhadores rurais que disputam 3 milhões e 200 mil hectares de terras agrícolas. Já em 1996, os mesmos conflitos aumentaram para 750, com o assassinato de 54 lavradores e de pelo menos três jagunços a serviço de fazendeiros. 


\section{CAPÍTULO 4 - O ESTADO, A AgRICULTURA E AS POLÍTICAS PÚBLICAS NO BRASIL}

Para se compreender as transformações pelas quais passou o setor agropecuário brasileiro nos últimos 40 anos, faz-se necessária uma análise mais aprofundada sobre o papel do Estado na elaboração das políticas públicas para este setor, já que ele é o órgão que atua como regulador das formas de acumulação e de exploração econômica da sociedade.

\subsection{O ESTADO E SEU PAPEL NA SOCIEDADE}

Na discussão deste tópico, é preciso ter-se a compreensão de como o Estado atua e de como são elaboradas as decisões dentro dele. Desta forma, a discussão teórica se pautará por apontamentos de Karl Marx que, mesmo não tendo formulado uma teoria sobre o Estado, aproximou-se muito dela, ao inferir que a estrutura econômica está na base do Estado, sendo, portanto, o Estado uma representação superestrutural que refletiria as contradições e seria determinado pela infra-estrutura econômica.

Embora a discussão sobre o Estado enquanto aparelho de classe ampliou a compreensão de seu papel na sociedade, entendo que o debate entre os marxistas ficou no plano teórico, impossibilitando assim o entendimento, na prática, de seu mecanismo e funcionamento.

De toda maneira, as análises de Althusser (1980, p.31-9), revelam como o Estado é entendido por esta corrente teórica, ou seja, como um aparelho repressivo, compreendendo, no seu interior, o poder de Estado e o aparelho de Estado. O poder é desejado através da luta de classes para, uma vez que a classe trabalhadora tome o poder, destruir o aparelho do Estado burguês e o substitua, de início, por um Estado proletário, e, na seqüência, eliminar o próprio Estado.

Indo além na discussão teórica, Gonçalves Neto (1997,p.117),afirma que, 
O conflito que se estabelece entre as classes tem por origem a diferença de interesses entre elas: se a realização da acumulação burguesa requer a eliminação do poder de decisão da classe trabalhadora, é necessário vencê-la e submetê-la a seus desígnios. Mas esta luta não se esgota em batalhas e, talvez, mais importante que simplesmente vencer a classe trabalhadora seja garantir a continuidade da vitória, a dominação, sem o que cada luta e cada vitória acabam compondo um fim nelas mesmas. É neste processo de luta constante que a classe vencedora, dominante, procura desenvolver mecanismos que garantam a estabilidade e a manutenção de uma ordem que defenda os seus interesses. Esses mecanismos comporão o Estado, o qual terá por função a guarda da ordem dominante, no caso burguesa. Não se trata somente de garantir as condições atuais de produção mas também da garantia de que essas condições serão reproduzidas no futuro.

Um outro aspecto a ser apontado com relação ao papel do Estado, é a questão da defesa do capitalismo mesmo que, em certos momentos, aparentemente se oponha aos interesses da elite, como afirma Poulantzas (1985 p. 193-4),

O Estado pode cada vez menos calcar sua estratégia econômica sobre a política geral de organização da hegemonia. Ele deve continuar a tomar decisões absolutamente essenciais então para a reprodução do capital, mesmo quando isso cria graves problemas para sua hegemonia: essas disposições agudizam exatamente as contradições no seio do bloco no poder e entre este e as classes dominantes, e tornam-se um fator maior de crises que, por isso mesmo, ultrapassam a simples crise econômica.

Pode-se notar, contudo, que, apesar de ter a infra-estrutura econômica como base de formação, o Estado não deixa de apresentar certo dinamismo com relação ao seu caráter de poder e de decisão; assim, muitas vezes, ele altera essa infra-estrutura, mantendo, todavia, privilégios que busquem atender interesses mais amplos na manutenção do sistema. Por isso, alguns avanços conquistados pela classe trabalhadora, através da luta de classes, como estabilidade de emprego, diminuição da jornada de trabalho, aumento de salários, foram decisões tomadas pelo Estado para, de um lado, ceder, e de outro, manter as condições futuras de acumulação.

Sob uma aparência de neutralidade, de representação entre classes conflitantes, entre capital e trabalho, o Estado

desempenha seu papel.....síntese, sumário, comprehensio da sociedade civil considerado no seu relacionamento consigo próprio. Não se trata unicamente duma representação estática, que viesse espelhar o tecido resultante da luta de classes, mas dum processo sistemático de representar que realiza, no imaginário, uma conciliação impossível no real. (GIANOTTI, 1983, p. 294) 
Observa-se, assim, o papel conciliador que o Estado representa na articulação destas classes, que têm interesses opostos, sendo que tal papel só é possível através das leis do Direito, que são reconhecidas e aceitas pelas classes.

A classe trabalhadora, entretanto, tem ciência de que essas leis não a favorecem, mas asseguram sua continuidade como classe, isto é, a lei privilegia a proteção à propriedade privada e ao capital, mas, simultaneamente, dá condições para que a classe trabalhadora continue lutando por mudanças na sua realidade.

Compreendo, então, que o Estado e a sua representação junto à sociedade se dá como aparelho de dominação de classe, ora agindo como mediador "neutro", ora se opondo aos interesses da burguesia; contudo, a forma como ele atua na estrutura econômica, através de medidas políticas, revela que o poder e a representação exercidos por ele mantêm, no conjunto da economia, a classe trabalhadora como subordinada, tanto ao aparelho Estatal quanto aos interesses burgueses.

Ademais, deve-se ter claro que, embora o interesse na realização do capital seja um propósito comum, ocorre, dentro da classe dominante, uma luta intraclasse pela obtenção de maior poder e conseqüente influência nas decisões políticas.

Ora, neste raciocínio é possível observar-se como o setor agropecuário tem se situado no interior do Estado e da economia em relação a outros setores, garantindo uma certa atenção do Estado quando da formulação de planos de desenvolvimento da economia; nota-se assim que, mesmo com a perda de posição política e econômica do setor agropecuário frente ao setor industrial, esse não perdeu suas possibilidades de acumulação.

Contudo, mesmo dentro do setor agropecuário deve-se destacar que estas possibilidades de acumulação não ocorreram de forma homogênea, como visto no capítulo 3 que discorreu sobre o capitalismo no campo brasileiro e a agricultura nos anos 1980-90, nos aspectos econômicos e de estrutura fundiária.

Posto isso, pode-se entender que o papel do Estado e das políticas públicas na agricultura brasileira

instituídas....a partir da década de 1960, centrada no crédito subsidiado ao setor rural, procurará responder aos desafios criados pela necessidade de modernização da agricultura brasileira: seu objetivo é conceder à agricultura a acumulação requerida sem mexer no mecanismo dos preços, transferindo parte da mais-valia em seu poder (Estado) para o setor agrário. E a indústriasetor predominante-também mantém seu potencial acumulativo que é, até, ampliado, uma vez que o crédito subsidiado é estendido sobretudo para a 
compra de produtos industriais, dinamizando a produção de matérias-primas de origem rural e o abastecimento urbano sem pressões altistas nos seus preços. (GONÇALVES NETO, 1997. p. 122)

Em resumo, estas políticas foram implantadas sem que fossem feitas mudanças nas formas de acumulação da classe dominante, permitindo que coexistissem interesses desiguais entre os setores que desejam controlar os principais fatores econômicos. 
4.2. NOTAS SOBRE A POLÍTICA AGRÍCOLA BRASILEIRA - DÉCADAS DE 1960-1980

A análise dos planos de governo do período 1960 a 1980, demonstra que os mesmos permaneceram apenas nas intenções, como bem observou Gonçalves Neto (op. cit.). E, apesar de que os mesmos não tenham se materializado completamente a ponto de transformarem a realidade, eles servem para se entender e analisar o quadro políticoeconômico desse período.

Destaco a seguir os planos governamentais nos aspectos ligados à agricultura; assim, no período de 1963-1965, tivemos o Plano Trienal de Desenvolvimento Econômico e Social, que apontava mudanças na estrutura de custos agrícolas, e ressaltava como problema principal da agricultura brasileira o fato de que,

Todos estudos e investigações sobre as causas do atraso relativo da agricultura brasileira, da sua baixa produtividade e da pobreza das populações rurais conduzem unânime e inevitavelmente, à identificação das suas origens na deficiente estrutura agrária do País, a qual se constitui no mais sério obstáculo à exploração racional da terra, em bases capitalistas e de permanente aprimoramento tecnológico da atividade agrícola, que viriam a emprestar à produção a flexibilidade reclamada pelo processo de desenvolvimento da economia nacional e pelo rápido crescimento da população ${ }^{23}$.

Nesse plano, a reforma agrária aparece como fundamental para a alteração da estrutura fundiária, que, ao limitar o desenvolvimento, impossibilitaria uma conseqüente modernização da agricultura.

A expansão da produção de alimentos, compatível com o estímulo da demanda, a correção de distorções e deficiências no setor de produtos de exportação, e a produção de matérias-primas para o mercado interno ${ }^{24}$, foram os três objetivos do plano neste setor. Reconhecia-se, ainda, a participação fundamental do governo na consecução dos mesmos. Trazia também para a discussão, a questão do crédito agrícola, da política de preços mínimos, da produção de equipamentos agrícolas, dos fertilizantes, dos defensivos, do

\footnotetext{
${ }^{23}$ Brasil. Presidência da República. Plano trienal de desenvolvimento econômico e social 1963-1965 (síntese), p.140.

${ }^{24}$ Ibid.,p.149-50.
} 
armazenamento e silagem da produção, além de incentivar a interligação de rodovias de potencial econômico, rodovias de penetração e adequação dos ramais ferroviários.

O plano seguinte, chamado de Programa de Ação Econômica do Governo (1964-1966), foi proposto pelo então governo militar, tendo por base a reformulação da estrutura econômica nacional e a retomada do crescimento econômico e social. Com relação ao setor agropecuário, este plano iria reproduzir o Plano Trienal, ao afirmar que a agricultura era atrasada, apresentando baixa produtividade e que, por isso, provocava seguidas crises no abastecimento e conseqüentes altas de $\operatorname{preços~}^{25}$.

Privilegiando o crescimento econômico era necessário, então, que houvesse mudanças profundas no setor agrícola, para que ele sustentasse o papel que lhe cabia no processo de desenvolvimento do país.

Dentre os principais fatores levantados como limitadores se destacam os rendimentos e a produtividade agrícolas, que se apresentavam sem aumento expressivo, aliados à dificuldade de difusão dos procedimentos modernos, seja pela dispersão física das unidades de produção, seja pela baixa escolaridade do homem do campo.

Ressaltava ainda o problema da estrutura agrária ${ }^{26}$, mostrando os limitantes: de um lado, a alta concentração fundiária brasileira, que reduzia a otimização do uso do solo e de mão-de-obra; e, de outro, os minifúndios, pelas dificuldades de utilização de máquinas. Contudo, este plano apresentava uma proposta modesta de reforma agrária, entendendo que não havia excedente de mão-de-obra, face aos sistemas e técnicas que predominavam no uso da terra; e apontava então, como ponto mais importante, a regulamentação das relações contratuais do trabalhador rural.

O documento enxergava que uma Reforma Agrária

de sentido tradicional não pode remediar a queda de produto derivado do declínio da produtividade do trabalho e do solo; segue-se que o tipo de reforma que o País deve realizar não pode considerar a redistribuição em termos do imóvel rural. Terá de incorporar a esse processo de mudança econômico-social elevado conteúdo de política agrícola, traduzido em medidas tais como educação, novos esquemas de distribuição da terra, organização cooperativa e melhoria do sistema de crédito rural ${ }^{27}$.

\footnotetext{
25 Brasil. Ministério do Planejamento e Coordenação Econômica, Programa de ação econômica do governo 1964-1966 (síntese), p.15.

${ }^{26}$ Texto do Estatuto da Terra, cf. Brasil. Leis, decretos, etc. "Lei n 4.504 de 30 de novembro de 1964”. In: Campanhole, Hilton Lobo. Legislação agrária. São Paulo: Atlas, 1980, p. 9-65.

27 Ibid., p. 106.
} 
Assim, as metas propostas direcionavam-se para um aumento da produtividade de alimentos, de matérias-primas e produtos exportáveis; e, por outro lado, a diminuição de importações agrícolas, em especial a do trigo. Outro aspecto que comparecia nas metas era a questão de colonizar ${ }^{28}$ áreas vazias e ociosas à produção, bem como poderia resolver o problema da concentração demográfica de algumas regiões.

Havia também no plano a intenção de eliminar o controle de preços e de facilitar a exportação; de ampliação da política de preços mínimos, do crédito agrícola, e da capacidade de armazenagem; da intensificação do uso de adubos, sementes melhoradas e corretivos; de investimento em mecanização, pesquisa etc. ${ }^{29}$

As Diretrizes do Governo de Costa e Silva ${ }^{30}$, juntamente com a elaboração do Programa Estratégico de Desenvolvimento, resultariam no Plano Trienal (1968-1970), que tinha por metas para a política econômica acelerar o desenvolvimento e conter a inflação.

Essas Diretrizes de Governo revelam, que entre outras áreas estratégicas, quais são os principais objetivos para o setor agrícola que pudessem auxiliar no alcance dessa meta: o aumento da produção e da produtividade agrícola, ligada à mudança tecnológica, e a modernização do sistema de abastecimento. Com relação aos primeiros, acrescentam-se como estratégias o fortalecimento e a especialização do crédito rural e o incentivo à industrialização no meio rural.

No que diz respeito à reforma agrária, o documento a coloca como forma de estabelecer uma melhor organização no meio rural, que deveria ser alcançada através de processos democráticos em "colônias auto-administráveis”. 31

Desta forma, devido a novas alianças e orientações técnicas que alcançavam os ministérios econômicos, o projeto de reforma agrária passa gradativamente para o grupo de mudanças secundárias. Os recursos e os esforços para a transformação do setor rural ficariam cada vez mais centrados na modernização da agricultura.

O plano Metas e Bases para a Ação de Governo (1970-1973) foi implantado no governo de Emílio Garrastazu Médici, que sucedeu o de Costa e Silva.

\footnotetext{
28 Ibid., p.115-8.

29 Ibid., p. 151-4.

30 Brasil. Ministério do Planejamento e Coordenação Geral. Diretrizes de governo. Programa estratégico de desenvolvimento.Brasília, 1967.

31 Ibid., p.79.
} 
No contexto do chamado "milagre brasileiro", esse documento tinha como intenção principal o progresso social e a distribuição de renda, propondo uma "Revolução da Agricultura e Abastecimento”, assim expressa:

na década de 70 [...] dotar a Agricultura brasileira de um sistema de apoio, financeiro e fiscal, capaz de produzir a transformação tecnológica e o fortalecimento acelerado de uma agricultura de mercado, sensível aos estímulos de preços; realizar a expansão de áreas, principalmente de espaços vazios, no Centro-Oeste (zona dos 'Cerrados'), no Norte e nos vales úmidos do Nordeste; converter em realidade a Reforma Agrária, nas áreas em que o sistema de propriedade da terra se constituir obstáculo ao aumento de produtividade e à melhoria de condições do trabalhador rural; transformar 0 Brasil em importante exportador de carne e outros produtos agrícolas não tradicionais; efetivar a modernização do sistema de comercialização de produtos agrícolas, notadamente nos grandes centros urbanos ${ }^{32}$.

Ainda no governo de Médici, foi elaborado o I Plano Nacional de Desenvolvimento - PND (1972-1974). Com uma proposta ainda mais arrojada, apoiada no “milagre brasileiro”, esse plano tinha como objetivos principais colocar o Brasil, no espaço de uma geração, na categoria dos países desenvolvidos; duplicar a renda per capita (comparativamente a 1969) e expandir a economia, garantindo taxas de crescimento da ordem de $8 \%$ a $10 \%$ anuais $^{33}$.

O que vai diferenciar esse plano dos anteriores é que, ao propor modernizar e dinamizar setores, ele não aponta para os problemas estruturais da agricultura nem para seu caráter complexo.

Contudo, com relação ao tema reforma agrária, nota-se que essa expressão não aparece no documento; antes, ela é tratada, principalmente com referência ao Nordeste, como redistribuição de terras ou mesmo desapropriações, com indenizações.

No âmbito nacional, há, no período seguinte, o esgotamento do “milagre brasileiro” e, no âmbito internacional, com a crise do petróleo, ocorrem profundas mudanças na conjuntura econômica mundial.

Neste cenário, é editado, no governo de Ernesto Geisel, o II Plano Nacional de Desenvolvimento (1975-1979), que se diferenciaria dos planos anteriores nos seus principais objetivos, com destaque para o problema do balanço de pagamentos, que se direcionavam para a manutenção do crescimento acelerado dos últimos anos e reafirmavam a

\footnotetext{
32 Brasil. Presidência da República. Metas Bases Para a Ação do Governo, p. 89.

33 Brasil. Presidência da República. I Plano Nacional de Desenvolvimento (PND) - 1972/74
} 
política gradualista de contenção da inflação, a manutenção em relativo equilíbrio do balanço de pagamentos, a realização política da melhoria da distribuição de renda, a preservação da ordem política e social, a realização do desenvolvimento sem deteriorização da qualidade de vida e sem a devastação dos recursos naturais ${ }^{34}$.

O tema reforma agrária volta à pauta nesse documento; entretanto, os movimentos de reivindicação já haviam reduzido sua pressão.

A agricultura e a pecuária passam, então, a ter neste cenário uma maior exigência de desempenho, pois assumem uma posição de destaque na estratégia de desenvolvimento, assim proposta:

O objetivo é levar a capacidade empresarial, que já se mostrou apta a desenvolver a indústria e outros setores urbanos, à atividade agropecuária nacional. através da ampla disseminação da empresa rural - pequena, média e grande -, principalmente pelo apoio financeiro e fiscal do Governo, que melhor equacionarão problemas como o de induzir ao uso de projetos, de levar em conta os cálculos de rentabilidade e estímulos de preços, de empregar a mais moderna tecnologia, considerando a relação entre preços de insumos e produtos ${ }^{35}$.

Ao buscar, após estas notas, destacar o propósito desses planos, em especial no que diz respeito à agricultura, fica ainda mais claro que ela passou a ocupar um papel subordinado, seja no nível econômico ou no de decisões, sendo o comando vindo do setor urbano-industrial.

Acrescenta-se que, mesmo sendo colocado nesta posição, o setor agrícola, por vezes, teve, em alguns planos estatais, um papel de destaque no processo de desenvolvimento, não sem antes ter tirado de cena a participação popular e, por outro lado, ter mantido uma política de alianças ligadas principalmente ao grande capital nacional e internacional.

Já no final da década de 1970, podiam-se notar indícios de uma enorme crise, pois a inflação superara o patamar de 40\%, as taxas de crescimento do PIB declinavam ano a ano e a dívida externa alcançava US\$ 60 bilhões.

Em linhas gerais, pode-se afirmar que, o início dos anos 1980 marcou um período fortemente recessivo, que, após a moratória do México, agravou-se, havendo a

\footnotetext{
34 Brasil. Presidência da República. II Plano Nacional de Desenvolvimento (1975-1979), p. 28-9.

${ }^{35}$ Ibid., p. 43.
} 
redução drástica do fluxo de capitais externos ao país, com quedas expressivas do PIB em 1981 e 1983.

Conforme ressalta Delgado (1988, p. 79-80), os países da América Latina, com as mudanças nas condições de financiamento da dívida externa, buscaram políticas que pudessem garantir saldos comerciais crescentes para cobrir os custos da dívida.

O governo brasileiro buscou esses saldos comerciais crescentes principalmente no setor agrícola e nos ramos agroindustriais processadores, e,

pode-se afirmar que no período 1981/85 foram particularmente importantes as políticas de câmbio e de salários, pois permitiram redimensionar a produção agrícola para a obtenção de excedentes exportáveis. Em termos de política agrícola propriamente dita, os preços mínimos foram ganhando destaque com o objetivo claro de compensar o papel declinante do crédito rural $^{36}$.

Contudo, conforme assinala Buainain (1987), houve mudanças na orientação das políticas agrícolas após 1985, com um aumento real de quase 30\% na política de crédito rural; os valores básicos de custo foram reajustados 20\%, em média; e os preços mínimos, melhor remunerados. Por outro lado, o governo estabeleceu condições diferenciadas para a concessão do crédito rural, que favoreceu, por um tempo, pequenos produtores, bem como a produção de alimentos básicos.

Todavia, devido à inflação, que se elevava desde 1984, foi decretado, em fevereiro de 1986 o Programa de Estabilização Econômica - Plano Cruzado, que se apoiou na desindexação e no tabelamento de preços por um ano. No período do congelamento, para manter os preços estáveis, o governo realizou importações vultosas, sobretudo de alimentos, para atender a demanda; reduziu, então, o saldo da balança de pagamentos, instituiu subsídios e reduziu alíquotas. A política fiscal se tornou então um apêndice do controle de preços, provocando um maior agravamento do caixa do setor público.

A princípio, as condições favoráveis oferecidas pela estabilização levaram os agricultores a novos investimentos, contudo, no final de 1986, a volta da inflação fez com que esses empréstimos, principalmente aqueles do crédito para investimento, se tornassem escorchantes. Assim,

O resultado foi um crescimento acentuado do grau de endividamento do setor, especialmente dos pequenos produtores [grifos meus], muitos dos

${ }^{36}$ Silva, José Graziano da, A nova dinâmica da agricultura brasileira. 1996, p. 113. 
quais acabaram por perder seus bens, inclusive as terras que possuíam, obrigando o governo a um perdão generalizado das dívidas financeiras contraídas para plantar a grande safra de 1986/87. (GRAZIANO DA SILVA, 1996. p.115)

Conforme analisou Rezende (1990, p. 510), o setor agrícola brasileiro foi profundamente afetado "pelo agravamento do quadro macroeconômico e, em particular, pelas estratégias - seja via ‘choques', seja via 'moeda indexada' - adotadas pelo governo para controlar a inflação”. Neste aspecto, pode-se dizer que a instabilidade financeira do período tratado tornou inviável a proposta de política agrícola que combinava crédito rural sem subsídios com preços mínimos compensadores, embora não se possa inferir que as políticas públicas dos anos 1980 tenham sido maléficas para todos os segmentos da agropecuária brasileira $^{37}$.

Importante destacar, neste período, a proposta do Plano Nacional de Reforma Agrária, no governo Sarney, que atingiu o patronato rural em um momento de indefinição de representação, pois havia disputa entre a Confederação Nacional da Agricultura e os setores representados pelos fazendeiros de café, usineiros, produtores de trigo e soja entre outros. Contudo,

[...] essa dicotomia na representação do patronato rural seria rapidamente superada no que diz respeito ao enfrentamento do PNRA. [...] em razão do surgimento de uma organização que se propunha a representar os proprietários rurais no plano da luta política, a truculenta União Democrática Ruralista - UDR. (GRAZIANO DA SILVA, 1996, p. 120)

Por outro lado, outras entidades “progressistas”, tinham como proposta uma política agrícola que englobasse a política agrária. Ocorreu, então, que simultaneamente à assinatura do PNRA, houve a exposição que criou o Plano Nacional de Desenvolvimento Rural, tendo por objetivo "reduzir a reforma agrária a um capítulo de uma política agrícola que garantisse 'um desenvolvimento harmônico'. O programa de reforma agrária voltava assim ao seu âmbito original [...]” (GRAZIANO DA SILVA, 1996, p,121), isto é, limitada pelas transformações conservadoras da Nova República.

Se o patronato rural estava fortalecido, amparado pelo aparelho do Estado e com ampla representação legislativa, integrados na estrutura agroindustrial e nos circuitos econômicos, industriais e financeiros, a situação dos pequenos agricultores e proletários rurais

${ }^{37}$ Cf. José Graziano da Silva, 1996, p.118. 
evoluía no sentido contrário. A crise da pequena produção, desde meados dos anos 1970, entrou em estado crônico, provocando um crescimento organizativo e político-ideológico representado pela corrente sindical ligada à CUT, à CONTAG - sindicalismo ligado ao estado e à esquerda moderada - e o Movimento dos Trabalhadores Rurais Sem Terra (MST), constituído como organização autônoma em $1985^{38}$.

Ainda com relação às políticas agrícolas, Graziano da Silva (1996) salienta que, embora o PNRA enfatizasse a necessidade de criar um conjunto de políticas de apoio aos assentamentos, isso nunca ocorreu e ressalta que,

A política de reforma agrária da Nova República, enquanto existiu, se fez de forma independente e, poderíamos até dizer, apesar das políticas agrícolas vigentes: as mesmas razões que sempre excluíram os pequenos produtores com muito mais razão excluíram os assentados do seu rol de beneficiários [...] quando precisaram de crédito foi necessário desenhar um sistema à parte para os assentamentos: o PROCERA, gerido pelo BNDES. (GRAZIANO DA SILVA, 1996. p.123)

38 Para um maior aprofundamento desse processo representativo, confira em Fernandes (1994), Stédile (1994) entre outros. 


\subsection{AS POLÍTICAS PÚBLICAS ECONÔMICAS E SOCIAIS - DÉCADA DE $1990^{39}$}

A década de 90 foi marcada por muitas mudanças, tomando-se em conta a forma de inserção da economia brasileira na economia internacional, ou seja, uma economia voltada para o mercado externo.

Pode-se destacar que esse processo de abertura comercial, no governo Collor, teve como objetivo uma nova política industrial que estimulasse a modernização da indústria nacional, através da concorrência externa. Entretanto, essa abertura ocorreu sem o acompanhamento de políticas que considerassem novos investimentos em infra-estrutura, problemas regionais, linhas de financiamento, etc., e, por conseguinte, seu principal impacto foi colocar muitos setores em dificuldades maiores do que as já existentes.

Juntamente com essa mudança ocorreu o início de um processo de redefinições das funções do Estado, sendo o de privatizações seu aspecto mais relevante. Aqui, é importante ressaltar que esse processo também foi colocado em prática sem nenhuma visão estratégica; ele se justificava por argumentos como a esperada eficiência dos setores produtivos e a possibilidade dos investimentos serem retomados através de recursos privados; e, paralelamente, persistia a crise fiscal do Estado.

A relação intra-setor público foi também outra importante mudança, pois, até a Constituição de 1988, tal setor se caracterizava pela forte centralização de recursos públicos e de decisões do governo federal, levando estados e municípios a se financiarem através do endividamento com diferentes fontes.

Os estados, então, recorreram aos bancos estaduais que possibilitaram uma maior flexibilização dos governos com relação aos recursos e, assim, possibilitando a possível realização de projetos. Os bancos estaduais e o Banco Central tinham uma relação que facilitava o desequilíbrio das contas, pois os primeiros, em dificuldades, recorriam à ajuda do segundo, aumentando os gastos do governo.

39 Esta exposição sobre políticas públicas está baseada em um levantamento efetuado pela Faculdade de Economia, Administração e Contabilidade, Departamento de Economia da Universidade de São Paulo denominado "Perspectivas para a micro e pequena empresa no desenvolvimento da Região Administrativa de Presidente Prudente”, de maio de 1998. 
A descentralização da arrecadação, provocada pela Constituição de 1988, não foi, entretanto, acompanhada da descentralização de gastos, trazendo à tona profundos desequilíbrios, assim como as dificuldades financeiras de Estados e Municípios. As elevadas taxas de juros praticadas ao longo da década de 90 e a diminuição das transferências devido à aprovação do Fundo Social de Emergência (FSE) - depois denominado de Fundo de Estabilização Fiscal (FEF) - aprofundaram ainda mais a crise já instalada.

A preocupação do governo federal foi a de estabilização econômica, e a estratégia de estabilização adotada restringiu o crescimento econômico e agravou a questão do desemprego.

O conjunto de medidas denominado "Brasil em Ação" propôs alguns investimentos em infra-estrutura e alguns programas de incentivos à geração de emprego; estas foram algumas das ações do governo federal, embora seja importante destacar que grande parte dessas ações sociais do "Brasil em Ação" foi executada, em última instância, pelos municípios. Este programa recebeu, posteriormente, o nome de “Avança Brasil”. 40

Tal conjuntura direcionou os estados e municípios a formularem políticas de atração de investimentos, pois a questão do desemprego e de problemas sociais que se aprofundavam, associadas à busca dos estados pela ampliação de suas receitas, levou à chamada "guerra fiscal”, entendida como a relocalização de investimentos.

Entretanto, a capacidade dos estados implementarem tais políticas ainda é bastante restrita, pois os condicionantes macroeconômicos básicos são delineados pelas políticas do governo federal, assim como a política tributária está atrelada à apreciação do conjunto dos Secretários da Fazenda dos Estados no CONFAZ (Conselho Nacional de Política Fazendária).

Contudo, apesar das restrições, muitos estados concederam benefícios fiscais, como por exemplo prazos maiores para o recolhimento do ICMS, financiamentos

\footnotetext{
40 Nome dado ao Plano Plurianual 2000-2003, contendo um conjunto de 377 programas governamentais planejados para serem implantados entre janeiro de 2000 e dezembro de 2003. A verba vem do orçamento da União, de agências oficiais de créditos, de fundos, da iniciativa privada, de estados e municípios. De acordo com a última revisão publicada no "Diário Oficial da União", em 6 de agosto [de 2002], deveria ser aplicado R\$ 1,29 trilhão nos projetos de janeiro de 2001 até o final de 2003. Os programas e metas são revistos periodicamente e já foram alterados por quatro leis, entre janeiro de 2001 e agosto de 2002, e pelas leis orçamentárias de 2000, 2001 e 2002. Decorridos 50\% do plano (2000 e 2001), R\$ 53,3 bilhões foram executados - 36,7\% da meta vigente. Fonte: Jornal Folha de São Paulo, 16/9/02. p.A5 e Decreto 4.322 de 5 de agosto de 2002, publicado no Diário Oficial da União.
} 
vantajosos para as empresas, comprometimento com investimentos para adequação de infraestrutura, participação acionária, etc.

A crítica que se faz com relação à racionalidade desta política é que, ao abrir mão de grande parte do fluxo de receita de impostos, ainda se expõe à possibilidade de piorar as contas públicas estaduais. É possível que a expectativa de retorno dos investimentos ocorra de fato em alguns estados; mas, se todos adotarem essa estratégia, os seus fatores determinantes passam a ser a proximidade do mercado consumidor, das fontes de matériasprimas, a dotação de infra-estrutura, a qualificação da mão-de-obra, entre outros, tornando esses benefícios fiscais irrelevantes, além de transferirem renda pública para capitais privados.

Existe, também, a questão do desequilíbrio regional provocado por tal política, pois alguns receberam e receberão mais investimentos em detrimento de outros e onde as perdas maiores foram e serão sempre as sociais.

Destas tentativas de atrair investimentos também participaram os governos municipais, nos mesmos moldes dos estaduais; contudo, aqueles apresentam maiores restrições com relação aos instrumentos, pois seus orçamentos são mais restritos e se apresentam com grandes dificuldades fiscais, limitando, desta forma, uma atuação que dinamizasse estes espaços.

O aumento do desemprego levou o governo FHC a adotar medidas que pudessem atenuar tal quadro. O programa "Brasil em Ação" constituiu-se em uma série de projetos em infra-estrutura (energia elétrica, gás natural, telecomunicações, transportes rodoviário, hidroviário -, modernização dos portos e saneamento básico) que contam com o apoio financeiro do setor público e do privado. Previa também ações sociais, nas quais se destacava a reforma agrária, um novo modelo de irrigação, o PRONAF (Programa Nacional de Fortalecimento da Agricultura Familiar), o PROCERA (Programa Especial de Crédito para a Reforma Agrária), o combate à mortalidade infantil, o habitar-Brasil, a carta de crédito, o pró-moradia, o pró-emprego, o PROEP (educação profissional), o crédito produtivo popular e PROGER (Programa de Geração de Emprego e Renda).

Destaco, a seguir, alguns programas que tiveram relações mais próximas com o objeto de estudo aqui proposto.

O PROGER é uma linha de financiamento destinada a recém formados e às micro e pequenas empresas (MPE). Esses recursos têm origem no FAT (Fundo de Amparo do Trabalhador), envolvendo, para sua operacionalização, além do CODEFAT (Conselho 
Deliberativo do FAT), mais três agentes: a comissão municipal de emprego (CME), o agente financeiro (AF) e a entidade credenciada (EC). Para a operacionalização do PROGER, é fundamental a existência da CME, cujas funções são articular-se com instituições e organizações envolvidas no programa, integrando suas ações e indicar áreas e setores prioritários para a alocação de recursos. Aos municípios cabe a iniciativa de montar a CME, que deve ser sancionada pela Secretaria de Emprego e Relações de Trabalho (SERT).

A elaboração de projetos cabe à entidade credenciada, que pode ser a universidade, o SEBRAE ou outras, que acompanha a execução e a capacitação gerencial dos beneficiários. A concessão do financiamento e a prestação de contas ao CODEFAT fica a cargo do agente financeiro.

O PROGER pode ser urbano e rural este último se destina a pequenos produtores e cooperativas rurais e ambos possuem condições semelhantes. Os investimentos financiados devem proporcionar a geração e a manutenção de emprego e renda. O risco do crédito é do AF, que presta contas ao CODEFAT. O repasse de recursos é interrompido quando a inadimplência atinge determinado nível que comprometa a devolução de recursos ao BNDES; assim, a taxa de inadimplência é muito baixa, isto é, inferior a 1\% dos empréstimos concedidos.

Esta taxa de inadimplência baixa leva a um impasse, pois o risco é do agente financeiro e a sua remuneração é muito baixa, não o estimulando a empenhar-se na liberação dos recursos por essa linha, ao lado de outras mais rentáveis para o banco; o oposto ocorre com o tomador, sendo as condições muito atraentes, se comparadas com outras alternativas. O AF acaba ampliando a burocracia necessária para a obtenção desses recursos, aumentando a demora no processo, e, conseqüentemente, desestimulando a demanda por não acreditar na possibilidade de obter os recursos.

O Programa de Educação Profissional (PROEP) tem por objetivo oferecer cursos de qualificação aos trabalhadores, principalmente os desempregados, facilitando seu retorno ao trabalho e também para aqueles que se encontram trabalhando, mas que necessitam de requalificação, sob o risco de perder o emprego. Esses cursos podem ser oferecidos por: instituições de ensino, sindicatos e organizações não governamentais; as propostas serão avaliadas tanto pela comissão Municipal de Emprego como pela Secretaria Estadual de Emprego e Relações de Trabalho, que julgam o mérito do curso, assim como sua qualidade e 
o credencial da instituição proponente para oferecê-lo. Após esta fase, credencia-se a instituição para a execução do curso.

As verbas do FAT para este fim são repassadas por meio das Secretarias de Emprego e Relações de Trabalho e serão destinadas a cobrir custos da entidade credenciada para a provisão do curso, com pessoal, equipamentos e também para viabilizar o transporte e a alimentação do trabalhador.

O PROCERA (Programa Especial de Crédito para a Reforma Agrária) foi uma linha de financiamento destinada aos produtores rurais assentados pelo programa de reforma agrária. Os limites de financiamento eram de $\mathrm{R} \$ 9.000,00$ por família, e se destinavam tanto para investimentos como para custeio. O forte subsídio - juros de 6,5\%, com carência de três anos para o início do pagamento, o prazo de sete anos para o pagamento e a não necessidade de oferecer garantias para obter o empréstimo - possibilitou uma capitalização significativa dos assentados, ampliando a chance de sucesso econômico. Todavia, este programa foi extinto e o financiamento para assentados é feito atualmente através do PRONAF.

O PRONAF (Programa Nacional de Fortalecimento da Agricultura Familiar) é outra linha de financiamento para o agricultor familiar proprietário, assentado, arrendatário, posseiro, parceiro ou meeiro. Foi institucionalizado e regulamentado pelo Decreto Presidencial $n^{0}$ 1.946, de 28 de junho de 1996, passando a integrar o Orçamento Geral da União. Esse programa tem por base a noção de gestão social fundamentada na descentralização, na participação e no estabelecimento de parcerias entre os agricultores familiares e os Conselhos Municipais de Desenvolvimento Rural. Aos conselhos municipais cabe analisar e aprovar o Plano Municipal de Desenvolvimento Rural ${ }^{41}$, assim como propor mudanças nas políticas do município, no que diz respeito ao setor agropecuário e, ainda, acompanhar e fiscalizar a aplicação dos recursos públicos.

O programa consiste em três linhas de atuação: PRONAF Crédito Rural; PRONAF Infra-Estrutura e Serviços nos Municípios; PRONAF Capacitação e Profissionalização e Negociação de Políticas Públicas.

No caso do agricultor familiar proprietário, por exemplo, com renda bruta

\footnotetext{
${ }^{41}$ O CMDR e o PMDR fazem parte do processo de descentralização implantado pela Constituição Federal de 1988 e, no âmbito estadual, pela Constituição Estadual de São Paulo em 1989.
} 
anual de até R\$ 27 mil, para custeio, as taxas de juro são de 4\% ao ano e o limite varia de R\$ 500 até R\$ 5.000,00, com um prazo de financiamento de dois anos.

Os créditos do PRONAF são concedidos tanto de forma individual como coletiva (grupo de produtores com finalidades coletivas) e grupal (grupos de produtores com finalidades individuais $)^{42}$.

\section{QUADRO 1. PRONAF - CARACTERÍSTICAS PRINCIPAIS DOS BENEFICIÁRIOS}

\begin{tabular}{|c|c|c|c|}
\hline GRUPOS & MÃO-DE-OBRA & RENDA FAMILIAR & PÚBLICO ALVO \\
\hline A & $\begin{array}{l}\text { Exclusivamente } \\
\text { familiar }\end{array}$ & $\begin{array}{l}\text { Não determina percentual de renda } \\
\text { mínima dentro do estabelecimento }\end{array}$ & $\begin{array}{l}\text { Agricultores familiares assentados } \\
\text { pelo Programa Nacional de } \\
\text { Reforma Agrária }\end{array}$ \\
\hline B & $\begin{array}{l}\text { Exclusivamente } \\
\text { familiar }\end{array}$ & $\begin{array}{l}\text { Não determina percentual de renda } \\
\text { mínima dentro do estabelecimento. Renda } \\
\text { de até R\$ 1,500.00 (excluída a } \\
\text { aposentadoria rural) }\end{array}$ & $\begin{array}{l}\text { Agricultores familiares } \\
\text { descapitalizados ou trabalhadores } \\
\text { rurais descapitalizados com } \\
\text { atividades não agropecuárias em } \\
\text { estabelecimento rural } \\
\end{array}$ \\
\hline $\mathrm{C}$ & $\begin{array}{l}\text { Trabalho familiar } \\
\text { predominantemente } \\
\text { com possibilidade de } \\
\text { contratação eventual } \\
\text { de terceiros }\end{array}$ & $\begin{array}{l}\text { Renda de } \mathrm{R} \$ 1.500,00 \text { até } \mathrm{R} \$ 8.000,00 \\
\text { sendo } 80 \% \text { no mínimo, proveniente da } \\
\text { exploração agrícola e não-agrícola do } \\
\text { estabelecimento, podendo atingir até R\$ } \\
16.000,00 \text { para as atividades de } \\
\text { avicultura, bovinocultura de leite, } \\
\begin{array}{l}\text { aqüicultura, caprinocultura, ovinocultura, } \\
\text { fruticultura, olericultura, sericicultura e } \\
\text { suinocultura }\end{array}\end{array}$ & $\begin{array}{lrr}\text { Agricultores familiares } & \text { ou } \\
\text { trabalhadores } & & \text { rurais } \\
\text { descapitalizados com atividades } \\
\text { não agropecuárias r em } \\
\text { estabelecimento rural }\end{array}$ \\
\hline $\mathrm{D}$ & $\begin{array}{l}\text { Utilização de mão- } \\
\text { de-obra familiar e } \\
\text { até dois empregados } \\
\text { permanentes }\end{array}$ & $\begin{array}{l}\text { 80\% da renda familiar devem provir do } \\
\text { estabelecimento de } \quad \text { exploração } \\
\text { agropecuária ou não agropecuária. Renda } \\
\text { bruta anual entre } \mathrm{R} \$ 8.000,00 \text { até } \mathrm{R} \$ \\
27.000,00\end{array}$ & $\begin{array}{l}\text { Agricultores familiares e } \\
\text { trabalhadores rurais } \\
\text { descapitalizados com maior nível } \\
\text { de capitalização que exerçam } \\
\text { atividades agropecuárias ou não } \\
\text { agropecuárias em estabelecimento } \\
\text { rural. }\end{array}$ \\
\hline
\end{tabular}

Fonte: DESER (1999)

Embora as propostas aqui apresentadas possam ser consideradas adequadas às necessidades sociais, muitos destes projetos têm ficado somente no papel, segundo a Folha de São Paulo (11/10/99, p. A-5). Em levantamento realizado pela Câmara, através do SIAF (Sistema Informatizado de Acompanhamento dos Gastos Federais), constatou-se que, "se no conjunto de mais de 60 empreendimentos, o Brasil em Ação não está parado, seu ritmo é

\footnotetext{
42 Informações atualizadas: Cf. Política Agrícola: Novas Regras do PRONAF. Disponível em: www.incra.gov.br/fao/diretrizes.htm, 2000.
} 
bastante lento [...] o SIAF registrava apenas 34,66\% de liberação dos recursos previstos no Orçamento de R\$ 5,7 bilhões”. 43

Desta forma, com relação ao PRONAF, que tem por objetivo priorizar o produtor familiar, observa-se que os princípios norteadores do programa são limitantes e excludentes no que diz respeito a benefícios para os produtores familiares e, embora diversos ajustes tenham sido realizados desde sua implementação, ele não tem sido adequado às demandas dos agricultores e muito menos revertido a lógica da política agrícola brasileira que sempre privilegiou o latifúndio. Assim, as “ações” por parte do poder público têm sido, na prática, ineficientes e excludentes.

43 Cf. Artigo Folha de São Paulo, 16/09/02, p. A4-5; 23/9/02, p. A4.; Hespanhol (2000, p.97-109), Pereira (2002). 


\subsection{POLÍTICAS PÚBLICAS ESTADUAIS - GOVERNO DO ESTADO DE SÃO PAULO}

De fato, na guerra fiscal desencadeada nos últimos anos, provocada por fatores como a ausência de política desenvolvimentista por parte do governo federal, o aumento do desemprego, as pressões sociais e os problemas fiscais, o Estado de São Paulo teve pouca atuação neste processo.

Isto se deu pelo fato de o Estado de São Paulo ser responsável pela maior parte da produção industrial, ao lado de sua concentração populacional e níveis de renda, que o tornam o maior mercado consumidor do País.

Além desses fatores, há ainda no Estado a melhor infra-estrutura nos aspectos físicos, social e de ciência e de tecnologia, ou seja a melhor malha rodoviária do país, aeroportos, universidades, centros de pesquisa, órgãos financiadores de pesquisa, níveis de saneamento, habitação, saúde, educação, maior disponibilidade de mão-de-obra qualificada, entre outros, o que atrairia naturalmente novos investimentos.

O gasoduto Brasil-Bolívia e a hidrovia Tiête-Paraná, visaram consolidar ainda mais a qualidade desta infra-estrutura, pois a primeira ampliou a oferta de energia a um custo menor para as indústrias e, a segunda, poderá facilitar o escoamento da produção e a obtenção de matérias-primas de outras regiões. Aliado a esses aspectos, iniciou-se também no Estado um amplo processo de privatizações dos setores energético, ferroviário e de concessão de ferrovias, objetivado pelo governo para ampliar investimentos e a melhoria dos serviços de infra-estrutura.

Entretanto, o Estado de São Paulo recentemente deu início à utilização de outros instrumentos para apoiar investimentos industriais. Dentre esses instrumentos destacam-se a criação do Fundo Estadual de Incentivo ao Desenvolvimento Social (FIDES) e do Fundo Estadual de Incentivo ao Desenvolvimento Econômico (FIDEC), com a lei 9.363 de 24/07/1996, regulamentada pelo Decreto 41.610, de 04/03/1997, que foi depois alterada pelo Decreto 42.696, de 23/12/1997, quando foram definidas as finalidades do Programa Estadual de Incentivo Econômico, a composição e atribuições do Conselho Estadual de Desenvolvimento Econômico e Social (CEDES) e as regras do FIDES e do FIDEC. 
Estes fundos têm condições de financiamentos favoráveis, oferecendo por estes fundos taxa de juro de 5\% a.a., mais correção monetária, que pode ficar abaixo do índice oficial, até no mínimo de 50\% deste índice, no caso do FIDES, e, 75\%, no caso do FIDEC; o prazo de financiamento de até 12 anos, podendo ter até 3 anos de carência, e a participação do financiamento no valor total do investimento, variando de $25 \%$ a $50 \%$. O CEDES delimitou seis grupos de prioridades, sendo ele quem determina o enquadramento do projeto.

O FIDES prioriza projetos industriais geradores de emprego, de, no mínimo, 100 empregados, que sejam econômicos sob o aspecto do consumo de energia e que preservem o meio ambiente, entre outros requisitos. São considerados setores prioritários para esse fundo a agroindústria, alimentos, têxtil e vestuário, calçados e autopeças. O FIDEC apóia projetos industriais de acordo com as características tecnológicas e a relevância do projeto para o Estado de São Paulo em termos econômicos; são eles: eletrônica e informática, biotecnologia, material de transporte, química, petroquímica, plásticos e metal-mecânica.

Ficou definido pelo CEDES, para operacionalizar estes fundos, que a Nossa Caixa-Nosso Banco seria o agente financeiro responsável. Devido à baixa atividade econômica, foram definidas como regiões prioritárias, para dar início ao processo, o Oeste Paulista, o Meio - Oeste Paulista e o Sul Paulista.

A inclusão da Região Administrativa de Presidente Prudente se deu através do diagnóstico realizado na fase inicial do levantamento, descrito no início deste capítulo. Tal levantamento apontou que, para que essas medidas possam contribuir de forma eficaz para o desenvolvimento econômico e social do Estado, é necessário que ajustes fiscais possam otimizar uma significativa dotação de recursos.

Também foram criados o Programa de Inovação Tecnológica e o Programa de Apoio à Capacitação Tecnológica, ambos da FAPESP (Fundo de Amparo à Pesquisa do Estado de São Paulo), em colaboração com a FINEP (Financiadora de Estudos e Projetos). Visando a aproximação entre empresas e universidade, estes programas financiam o desenvolvimento de projetos de interesse empresarial nas universidades, além de intensificar o desenvolvimento tecnológico no Estado, criando novos diferenciais para a atração de investimentos industriais.

A criação de câmaras setoriais e regionais também foi iniciativa do governo estadual; tais câmaras foram definidas de acordo com as dificuldades pelas quais passam certos setores e regiões do Estado, como a Câmara do Setor têxtil e Vestuário, a Câmara do 
Setor Sucro-Alcooleiro, a Câmara do Setor de Calçados, a Câmara do Setor da Citricultura, a Câmara do Setor Portuário, a Câmara do Setor Florestal, a Câmara do Setor de Comunicação e Informática e a Câmara Regional do Grande ABC. As duas primeiras e a última já foram implantadas; quanto as demais, estão em fase de implantação. O Programa de Desenvolvimento e Competitividade do Estado de São Paulo (PDC), do qual fazem parte estas Câmaras Paulistas de Desenvolvimento, foi criado em 03/10/1995.

As Câmaras Setoriais têm por objetivo a geração de emprego, a ampliação da competitividade das industrias paulistas, a mobilização dos setores organizados da sociedade, além da formação de uma cultura de parcerias entre os atores envolvidos.

A representação destas câmaras tem sido tripartite com representantes do governo, trabalhadores e empresários, que devem desenvolver diagnósticos consensuais a respeito da situação dos respectivos setores, e também propor ações que serão desenvolvidas pelos diversos atores assim como as formas de implementação.

Existe também o Plano de Estratégia Competitiva, cujas ações são: seminários regionais, fórum de representantes regionais, agências de desenvolvimento local, incubadoras, condomínios industriais e de serviços, pólos e parques tecnológicos, apoio aos municípios, etc.

Entretanto deve-se ressaltar que este conjunto de medidas que o governo do Estado de São Paulo adotou não possui qualquer coordenação, nem fica especificado os setores prioritários ou regiões, são desta maneira medidas isoladas, não configurando uma política industrial integrada. 


\subsection{PROGRAMAS DE OUTRAS ENTIDADES}

Pode-se destacar alguns projetos de outras entidades, ao lado destas ações do governo federal e das políticas estaduais, sendo eles o do SEBRAE, o da FIESP, o do BNDES, o do PNUD, e de outras entidades voltadas ao desenvolvimento e à geração de emprego. Dentre as ações destacadas, se objetiva, principalmente, o fortalecimento das micro e pequenas empresas.

Alguns estudos ressaltaram uma série de fatores que levam as micro e pequenas empresas ao fracasso, nos primeiros anos de existência, tais como a falta de capacidade gerencial, dificuldades para se inserir no mercado, o desconhecimento do setor de atuação, a falta de conhecimento técnico e a ausência de financiamento adequado, principalmente para capital de giro, entre outras.

Assim, entre as linhas de financiamento que têm por objetivo o desenvolvimento tecnológico e a capacitação gerencial estão a MIPEM (Micro e Pequena Empresa) SEBRAE e o Banco do Brasil, o AMPEG (Apoio à Micro e Pequena Empresa com Fundo de Garantia de Crédito) SEBRAE-FINEP.

Ao lado destas linhas existem outras específicas para cooperativas, produtores rurais e setor informal como o PRODEM-FAT, o PROGER RURAL, o BB-Giro incremental, o PROGER- Setor informal, etc.. O BNDES tem também um projeto de autogestão e co-gestão que visa financiar investimentos para empresas em funcionamento e para novas associações de trabalhadores que adotem os princípios citados de gestão.

Outro projeto de destaque voltado ao pequeno empresário do meio rural é o SEBRAE - Volta ao campo, que tem por objetivo assessorar tecnicamente pequenos produtores rurais tanto na parte da produção como na gestão dos negócios, em parcerias com as prefeituras.

O PNFC (Projeto Novas Fronteiras da Cooperação para o Desenvolvimento Sustentável) é outro projeto importante para o meio rural, dando-lhe apoio técnico, com o intuito de cooperar para maior eficiência na gestão e no fortalecimento das estruturas de integração econômica e social de instituições associativas, que executam o projeto e operam 
com base na auto-gestão. Ele tem o objetivo de ampliar a renda líquida dos associados, seja nas atividades agrícolas ou não agrícolas.

Dentro do PNFC, podemos destacar o PROINF (Programa de Integração na Agricultura Familiar), o qual tem por objetivo atuar junto às comunidades de agricultores familiares para uma otimização de recursos humanos, materiais, físicos e financeiros. Este programa tem a preocupação de respeitar as diversas características sócio- econômicas e culturais da clientela do programa, sendo que, em cada projeto, deve ser contemplado um grupo de 150 a 200 pequenos produtores familiares que devem se organizar na forma de associações ou cooperativas, em áreas de assentamentos de reforma agrária.

Tal programa pretende então, com a adoção de técnicas adequadas, possibilitar o aproveitamento total e racional das pequenas propriedades, tornando-as viáveis economicamente, além de contribuir para a diminuição de outros problemas sociais, econômicos e ambientais.

Por último, dentre os programas destacados neste trabalho, aparece o Programa de Modernização das Administrações Tributárias Municipais do BNDES, que tem como meta principal o aperfeiçoamento dos sistemas de arrecadação das prefeituras das capitais e municípios que apresentem potencial de receita própria economicamente explorável.

Para se candidatarem a este financiamento, os municípios devem constituir um Núcleo Especial de Trabalho e Modernização da Administração Tributária (NEMAT), vinculado ao Secretário de Finanças e com a participação de profissionais com conhecimento nesta área, e encaminharem o projeto de modernização tributária ao BNDES, para que se possa identificar, analisar e acompanhar o conjunto de ações para o aumento da eficiência fiscal na arrecadação. 


\subsection{POLÍTICAS PÚBLICAS E OS MUNICÍPIOS DA REGIÃO ADMINISTRATIVA DE PRESIDENTE PRUDENTE}

Foram selecionados, para a realização deste estudo ${ }^{44}$, os municípios de Presidente Prudente, Presidente Venceslau, Adamantina, Dracena, Osvaldo Cruz, Rancharia e Presidente Epitácio. Nele foi feito o levantamento dos tipos de incentivos concedidos e das ações voltadas tanto para o desenvolvimento do setor industrial como para o setor agropecuário e para a geração de emprego.

Contudo, neste trabalho destacar-se-á apenas dados relativos ao município de Presidente Prudente. Desta forma, quanto a incentivos aos investimentos industriais, Presidente Prudente conta com três distritos industriais, instalados em uma área de 45 alqueires, com um núcleo industrial que serve para qualquer tipo de indústria, e dois distritos industriais não poluentes; outro núcleo industrial está em fase de implantação.

As firmas que se instalarem nestes distritos poderão ter, como benefícios, a doação do terreno, a isenção de todos os impostos (IPTU e ITBI) e taxas municipais (Licença para execução da obra, localização do Estabelecimento, coleta de lixo, etc.) e a devolução de $50 \%$ da quota-parte do ICMS do município, arrecadado pela empresa. Já se encontram instaladas cerca de 100 empresas industriais, a maioria de pequeno porte. A definição dos benefícios consta na lei 4.545/97, que implantou a política de desenvolvimento industrial do Município de Presidente Prudente.

Ocorre que outros municípios têm a maioria dos incentivos e legislação muito semelhantes, e, no conjunto, os incentivos são pouco eficazes na atração de investimentos. Desta maneira, o local de implantação da empresa acaba sendo escolhido pela facilidade de escoamento da produção, da proximidade do mercado consumidor e/ou das fontes de matéria-prima, e da qualificação de mão-de-obra. Por outro lado, a capacidade dos municípios em se articularem de forma isolada é muito limitada, devido à escassez de recursos e instrumentos disponíveis.

\footnotetext{
${ }^{44}$ Efetuado pela Faculdade de Economia, Administração e Contabilidade, Departamento de Economia da Universidade de São Paulo denominado "Perspectivas para micro e pequena empresa no desenvolvimento da Região Administrativa de Presidente Prudente”, de maio de 1998.
} 
O município de Presidente Prudente já constituiu sua Comissão Municipal de Emprego, sendo credenciado para a liberação de recursos do PROGER. Contudo, a demanda por tais recursos na região tem sido pequena, pois se verificou que, além das comissões terem se constituído recentemente, muitas dificuldades a para liberação destes recursos são também colocadas pelos agentes financeiros, além das baixas oportunidades de investimentos na região, o que faz com que a demanda das pequenas e micro empresas por este tipo de financiamento seja muito baixa. Em Presidente Prudente, que é o maior município da região, no período de setembro de 1997 a abril de 1998, por exemplo, foram liberados apenas R\$ 144.348,52, sendo que R\$ 125.967 .08 para investimentos e R\$18.381,44 para capital de giro. Destes recursos liberados, cerca de 50\% foram para recém formados, e o restante para micro e pequenas empresas.

Pode-se destacar, com relação à qualificação profissional em Presidente Prudente a Escola de Curtimento de Couro (ECC), projeto inicialmente criado pelo SESI/SIESP, com o intuito de implantar, no município, um centro de qualificação que ensinasse ao aluno as etapas que envolvem o trabalho com couro, isto é, desde o abate, o curtimento, até a elaboração de produtos finais, como calçados, bolsas, etc. Aos alunos com perfil empreendedor seria possível instalar seu próprio negócio nas incubadoras para uma alavancagem, e, mais tarde estes, se deslocariam para instalações próprias.

A prefeitura de Presidente Prudente, na gestão 1997/2000, participou deste projeto e, para completar as obras, apresentou o projeto da escola ao PROEP (Programa de Expansão e Educação Profissional) do MEC / BID; foram obtidos, inicialmente, cerca de R\$ 2 milhões para sua execução e, na impossibilidade destas verbas serem repassadas para a prefeitura, foi criada uma fundação privada - Fundação Educacional Presidente Prudente, com a participação da prefeitura, da FIESP, do SENAI, entre outras entidades ${ }^{45}$.

Na administração 2001/2004, foi constituída nova fundação denominada Escola de Ensino Técnico Profissionalizante de Presidente Prudente.

Essa nova fundação renovou o convênio MEC/BID, nos mesmos moldes do anterior, recebendo também cerca de $\mathrm{R} \$ 2$ milhões para dar continuidade ao projeto e à montagem dos laboratórios. Está ainda em processo de licitação a aquisição de equipamentos de informática, de curtimento, de equipamentos laboratoriais, etc, bem como está em

${ }^{45}$ Essa fundação se desfez em Janeiro de 2001. 
discussão a proposta pedagógica, o plano e o regimento interno do curso que atenderá, a princípio, cerca de 40 alunos no período noturno. Além da Educação Profissionalizante, com cursos técnicos, haverá outros cursos de nível básico de qualificação, como, por exemplo, aqueles ligados à confecção de artefatos de couro ${ }^{46}$.

Outras ações dos municípios são a promoção de feiras e festas para a exposição e divulgação de produtos regionais e atração de turistas. É realizado em Presidente Prudente, a organização dos seminários TECNOCARNE e TECNOLEITE, onde se reúnem especialistas destes segmentos; eles discutem novas tecnologias e técnicas de gestão e potenciais de mercado, contribuindo, assim, para a divulgação regional e colaborando com o desenvolvimento de empresas regionais, através do contato com novas técnicas e com profissionais qualificados.

Além destes programas, outros que também se destacam são aqueles voltados para o campo. Presidente Venceslau é o único município do Estado de São Paulo engajado em um programa piloto que inclui outros sete, no Brasil, a implantar o PROINF ${ }^{47}$.

Dracena e Rancharia utilizaram o Projeto Volta ao Campo, do SEBRAE ${ }^{48}$.

E, naqueles municípios onde existem assentamentos de reforma agrária, como Teodoro Sampaio, Presidente Venceslau e Rancharia, houve a utilização de recursos do PROCERA.

Ao destacar, neste capítulo, o papel do Estado, a agricultura e as políticas públicas no Brasil, é possível compreender-se a lógica que comanda a política agrícola brasileira e o lugar ainda periférico ocupado pela produção agrícola familiar e pelo trabalhador rural.

A retórica liberal adotada pelo Estado, nos últimos 30 anos, levou a uma concentração maior da terra e da renda no campo; a pobreza aumentou e se acentuou, situação essa que leva a emergência de políticas sociais para o campo que proponham um enfoque

\footnotetext{
${ }^{46}$ Segundo informações da diretoria da Fundação Escola de Ensino Técnico e Profissionalizante de Presidente Prudente em maio de 2002.

${ }^{47}$ Programa de Integração na Agricultura Familiar- Tem por objetivo atuar junto às comunidades de agricultores familiares para uma otimização de recursos humanos, materiais, físicos e financeiros. Este programa tem a preocupação de respeitar as diversas características sócio-econômicas e culturais da clientela do programa, sendo que, em cada projeto, deve ser contemplado um grupo de 150-200 pequenos produtores familiares, que devem se organizar na forma de associações ou cooperativas, em áreas de assentamentos de reforma agrária.

${ }^{48}$ Tem por objetivo assessorar tecnicamente pequenos produtores rurais, tanto na parte da produção como na gestão dos negócios, em parcerias com as prefeituras.
} 
mais centrado no homem e não na economia. Possibilitando que o homem do campo seja sujeito de sua história.

Enquanto estudiosa das questões que afligem o campo brasileiro em suas múltiplas dimensões, procurei compreendê-las e mostrá-las através da realidade por nós pesquisada. 


\section{CAPÍTULO 5 - CONSIDERAÇÕES TEÓRICAS SOBRE O CONCEITO DE REGIÃO}

Frente à proposta de analisar e a refletir sobre o espaço rural do Sudoeste Paulista surge naturalmente o termo "região”, pois, ao estudar-se esse espaço estarei tratando da "Região de Presidente Prudente”. Entretanto, é fato que a questão do pluralismo conceitual com relação ao termo região, é entre os geógrafos, uma tradição de longa data.

A região é analisada por Corrêa (1997), como sendo caracterizada pela tradição geográfica e pelo pluralismo conceitual. O espaço era visto como sendo uma diferenciação de área e o debate era focado na busca de um conceito e de um método que dessem identidade à Geografia.

A partir de 1875 até a década de 70, no século XX, houve três grandes concepções de região. A primeira privilegiava dados da natureza, ou região natural; destacavam-se aí a Geografia Física e o determinismo ambiental, com uma visão darwinista/ neo-lamarkiana, usada para justificar a expansão colonial do período 1870-1920. Todavia, ela hoje não serve de referência, pois não explica o desenvolvimento econômico e social que o mundo experimenta desde então.

Uma segunda acepção usada era o historicismo, de base neokantiana, que propunha a separação entre ciências naturais e ciências sociais. A terceira é a região como paisagem cultural ou região paisagem, havendo, então, sob esta perspectiva, a transformação de paisagem natural em paisagem cultural, dando-se destaque aos traços culturais e gênero de vida; tal forma de se pensar a região como sendo região - paisagem ocorreu entre 1920-1950.

Já na década de 1950, nos países de língua inglesa, ocorreu a chamada revolução teorético-quantitativa, de base lógico - positivista. A região era, então, analisada a partir de propósitos específicos de regionalização, ou seja planejamento regional. Na década de 70, novas mudanças ocorreriam com o conceito de região, passando a ser analisado sob o domínio do movimento crítico na geografia, fundamentado na materialidade históricodialética marxista, ao lado da geografia humanista e da geografia cultural.

Anne Gilbert (1988), aponta três conceitos de região. Primeiro, o de região como organização espacial dos processos sociais, regionalização da divisão social do trabalho, 
associada ao modo de produção capitalista, o qual compreende processo acumulativo de capital, reprodução da força de trabalho e processos políticos e ideológicos, embora outros autores apontem ainda para a região como um resultado específico de classe, ou de uma cultura distinta, assim como de um regionalismo. Essa autora cita, entre outros, Corragio, Massey e Smith, autores que utilizam o conceito de região, segundo uma abordagem fundada no marxismo.

Segundo, a região como foco de identificação, ou seja, “conjunto específico de relações culturais entre um grupo e lugares particulares”, “apropriação simbólica de uma porção do espaço por um determinado grupo" e, assim, “um elemento constituinte de uma identidade”. Destacam-se, nesta abordagem, a geografia humanista, que trabalha com a filosofia do significado, analisando a região como o espaço vivido, e a geografia cultural (renovada), que faz um estudo das paisagens, e, nessa linha, aponta geógrafos alemães, franceses e anglo-saxões, como Pivetau, Tuan e Frémont.

E, terceiro, a região como meio de interações sociais, onde se tem uma visão política com base na idéia de dominação e poder, que são fatores fundamentais na diferenciação de áreas, conceitos defendidos por autores como Pred, Gregori e Raffestin.

Nota-se assim que o pluralismo conceitual se torna cada vez mais complexo. Correa $^{49}$ observa que os conceitos de região pós - anos 1970 estão apoiados na idéia de diferenciação de áreas, e não admitindo a tese da homogeneização mundial e do desaparecimento da região; todavia, tal discussão surge quando o mundo já se encontra dominado pelo capitalismo industrial, conforme autores como Eric Hobsbawn, em obra intitulada “A Era do Capital 1848-1875”50 . Como, então, pensar a região?

A economia é cada vez menos autônoma e mais dependente através dos processos gerais universais. Podemos dizer que, a partir da II Guerra Mundial, houve uma etapa superior da espacialidade capitalista com o processo mais intenso de globalização, aumentando a complexidade da fragmentação articulada da superfície terrestre, assim como a divisão territorial do trabalho, com suas especializações produtivas, e com características sociais, culturais e políticas, espacialmente variáveis.

Segundo Milton Santos (1997), as articulações se exprimem através dos

\footnotetext{
49 Roberto Lobato Correa. Trajetórias geográficas. Rio de Janeiro; Bertrand Brasil, 1997 .

${ }^{50}$ Eric Hobsbawn. A era do capital 1848-1875. Rio de Janeiro: Paz e Terra, 1997.
} 
fluxos materiais e imateriais que percorrem a superfície terrestre, fazendo a integração de pontos e áreas diversas; contudo, não acorreu a homogeneização global, pois as diferenças espaciais podem ter se acentuado ou mudado, criado ou recriado unidades regionais; outras áreas, entretanto, podem ser regiões de reserva, que poderão mudar no futuro.

As articulações dessas regiões preexistentes, refeitas ou recém-criadas, acentuaram a complexidade das mesmas em suas dimensões, formas e conteúdos, tudo isto dentro de uma economia mundial, que era posta em um único mosaico, até a segunda metade do século XIX.

Atualmente, este mosaico é irregularmente superposto; por isso, dependendo do ângulo de análise, pode-se privilegiar um dos diversos mosaicos superpostos.

Podemos, então, falar em rede.

Com relação às redes que articulavam as diversas regiões, o processo é similar, pois os fluxos são muito mais densos, variados e multidirecionados; as redes são atualmente planejadas e espontâneas, formais e informais, temporárias e permanentes, materiais e imateriais, regulares e irregulares. (CORREA, 1997).

A partir do pós-guerra, o espaço do homem viveu um processo rápido de reconstituição das diferenças espaciais, sendo esta uma das características da economia global, mesmo com a permanência das diferencialidades espaço-temporais. Desta forma, o espaço brasileiro representa um campo de estudo vasto neste processo de criação e do fazer, desfazer e refazer das regiões.

Nota-se assim que, nos diversos conceitos de região desenvolvidos pelos geógrafos, há uma resposta a observações passadas e presentes, formando um prisma com diversos ângulos do mundo real, já fragmentado e articulado e que tal quadro se acentuou com a globalização, tornando possível observá-lo de muitas formas.

Corrêa $^{51}$ afirma ser a diferenciação de áreas através de processos sociais e da natureza, que permite aos geógrafos falar em região, pois a geografia é um saber dotado de certa autonomia. Entretanto, este enfoque está dissociado da noção de unicidade hartshorniana, em que a singularidade está vinculada ao conceito de lugar, mas está associada a uma mediação entre o universal (processos gerais, dentre eles a globalização) e o singular.

${ }^{51}$ Op. Cit. 
Desta maneira, a particularidade se situa no plano espacial dando contorno à região, onde a ação das especificidades herdadas do passado e fincadas no espaço, juntamente com a coesão ou economias regionais de aglomeração, resultarão em concentração espacial de elementos comuns, em dada porção do espaço. E, a difusão destes fatores espalhará os elementos de diferenciação e seus limites espaciais impostos pela natureza e/ou criadas socialmente.

Assim, o caráter particular de região, com a globalização, não é mais autônomo dando, desta maneira, um destaque à categoria da particularidade, com suas inúmeras possibilidades de recortes espaciais, onde a realidade vai direcionar o conceito de região.

Para Santos (1997), as mudanças com relação à noção de região clássica se dão com a internacionalização do capital produtivo, paralela à fase técnico-científica atual do imperialismo, onde o ritmo no processo de acumulação se acelera, e ocorre uma seletividade maior da localização das atividades mais rentáveis.

Desta forma, os países do centro do sistema apresentam uma concentração econômica e espacial de capitais, gerais e particulares, esta, apesar da distribuição de equipamentos coletivos, acentua antigas desigualdades, através da desigualdade na criação de empregos "produtivos”, com suas subseqüentes conseqüências, trazendo empobrecimento para algumas áreas e dando uma nova feição à questão regional.

Nos países que estão à margem do centro, o caráter interno da divisão internacional do trabalho causa uma divisão interna do trabalho, a criação de valores de troca, a especialização mercantil dos subespaços. Simultaneamente, o processo de centralização econômica e geográfica se limita em determinadas áreas, ocasionando, com o restante do país, relações obrigatórias e assimétricas com o “centro”.

Este processo de decisões envolve não só a produção de bens, mas também serviços tradicionais ou modernos, e informação, incluindo aí decisões, o que torna a região polar do país um intermediário privilegiado, tanto nas relações internas quanto nas externas; a noção de região, fica então seriamente comprometida.

Santos $^{52}$ propõe, então, uma nova conceituação, entendendo que a região é locus de determinadas funções da sociedade total em um determinado momento, cujo

52 Op. Cit. 
passado, entretanto, já determinou divisões espaciais do trabalho criando, ao mesmo tempo, instrumentos de trabalho fixos que estão ligados a diferentes escalas do processo produtivo, onde novos instrumentos de trabalho se agregam a novas e renovadas atividades do presente.

Destaca também que, em uma região, esses bens imóveis (capitais fixos) ${ }^{53}$ são geografizados segundo uma lógica que ocorreu no momento de sua criação, não se podendo negar seu caráter de inércia. Esses capitais fixos, mesmo ficando envelhecidos diante de novas formas técnicas, não provocam, necessariamente, uma perda relativa de seu valor produtivo ou de sua capacidade de participar no processo de acumulação geral e dentro do ramo respectivo.

Conforme Santos ressalta, é a incidência das relações sociais sobre essas formas envelhecidas, que lhes assegura um lugar na hierarquia dos papéis. Tal aspecto é fundamental para a análise da questão, e está ligado à lógica do funcionamento da formação social nacional como um todo.

Desta maneira, Santos define região como sendo,

o resultado das possibilidades ligadas a uma certa presença, nela, de capitais fixos exercendo determinado papel ou determinadas funções técnicas e das condições do seu funcionamento econômico, dadas pela rede de relações acima indicadas ${ }^{54}$, existindo assim uma dialética entre esses fatores concretos, onde um fator influencia e modifica o outro.

O regional seria constituído de formas-conteúdo, isto é, um sistema de relações ligado à lógica interna de firmas e/ou instituições, que opõe resistências à lógica mais ampla, ou seja, nacional. Santos ressalta ainda que, a lógica espacial dessas várias produções e firmas tornam a análise mais complicada pois, cada produção organiza seu espaço segundo uma característica própria, podendo, a partir disso, surgirem conflitos localizados, ora periódicos, ora permanentes.

Quanto às firmas e suas instâncias de produção, há o destaque para os chamados “círculos de cooperação”, pois estes são difíceis de se limitar espacialmente, além de que este esforço de análise serviria, entre outras coisas, para a constatação da ausência de autonomia, ao se tratar de região como lugar de realização de atividades produtivas diversas.

\footnotetext{
53 Santos, 1997. p.67.

54 Ibid.
} 
Tem-se ainda que os agentes dificilmente podem se bastar com os processos, por assim dizer, puramente regionais pois, ao se analisar do ponto de vista espacial, o consumo de bens e mercadorias envolveria um circuito mais amplo.

Então, segundo Santos, deve-se considerar não somente a produção propriamente dita, mas também outras instâncias dela, pois os bens imóveis (fixos) vão caracterizar a área de uma forma particular, com autonomia de existência; entretanto, os mesmos não têm autonomia de funcionamento. Assim, a região e o lugar são lugares funcionais do todo.

O que complica esta abordagem é a dificuldade em se dividir socialmente a totalidade sob um olhar geográfico. Todavia, tal complexidade pode ser amenizada se tomarmos um ponto no tempo.

Ainda conforme Santos, mesmo com o dinamismo global e sua incidência sobre diversas áreas, algumas estão mais aptas a receberem

o impacto das novas relações sem determinar mudanças na organização espacial das formas-conteúdo precedentes....”e outras de receberem “o impacto das novas relações e encontrar um novo arranjo interno que permita a reprodução das condições anteriores ("reprodução" aqui não sendo um sinônimo de reprodução das relações técnicas, mas de reprodução das relações sociais que, naturalmente encontrarão outra "lei" e outros (novos) contornos na fase que, então, se inaugura). ${ }^{55}$

Para Lencioni (1999), a discussão da noção de região conduz à questão fundamental da disciplina geográfica, ou seja, a unidade entre a Geografia Física e Humana, onde a Geografia Regional, por vezes tentou tornar possível esta unidade, e também nos leva a refletir sobre os elementos conceituais que servem ao conhecimento em Geografia.

Assim como Corrêa (op.cit), Lencioni ${ }^{56}$ assevera que,

a idéia de região apresenta-se como particularidade, como mediação entre o universal e o singular, como mediação entre o global e local.......como parte de uma totalidade", pois, "viver significa conhecer o espaço circundante e produzir interpretações a partir das mais simples experiências. Significa perceber o espaço circundante como ordem próxima e produzir interpretações sobre o mundo como ordem distante.

\footnotetext{
55 Ibid., p.69.

${ }^{56}$ Lencioni, 1999, p.198.
} 
Desta forma, calcada neste referencial teórico que privilegia tanto o universal, através dos processos gerais decorrentes da globalização, quanto o singular, através do local e suas especificidades, é que analisarei o Sudoeste Paulista (a região de Presidente Prudente). Tomarei como recorte temporal as décadas de 1980 e 90, e o recorte espacial se dará nos 21 municípios do EDR - Presidente Prudente. Quando da análise dos dados secundários, trabalharei tanto com dados da SAA-SP para o EDR, mais recentes, quanto utilizarei dados da FIBGE, para fazer as análises de períodos mais longos. 
PARTE II 


\section{CAPÍTULO 6 - PROCESSO HISTÓRICO DA OCUPAÇÃO DA REGIÃO DE PRESIDENTE PRUDENTE}

A região de Presidente Prudente teve sua formação histórica baseada na ocupação da terra, no fim do século XIX, pelos precursores mineiros; conforme Monbeig (1984. p.133) “onde poderiam mais facilmente continuar a viver, conforme seus hábitos de criadores, acostumados aos grandes espaços, suficientemente à distância dos poderes constituídos”.

Este povoamento foi iniciado por José Teodoro de Souza, no território compreendido entre os Rio Tietê, ao norte, Paraná, a oeste e Paranapanema, ao sul (Figura 2). Os interessados em adquirir terras foram atraídos, segundo Cobra (1923, p.35), pela “qualidade do solo, o preço ínfimo que se pagava por um córrego, por um ribeirão, com todas as vertentes” e acrescenta que foi a Guerra do Paraguai o acontecimento que veio apressar a vinda de grande parcela de povoadores, principalmente mineiros, de 1865 em diante.

Conforme Abreu (1972, p. 24),

além de pequenas lavouras de feijão, milho, arroz, batatas e mandioca para o consumo, a principal atividade econômica dos pioneiros vindos de Minas Gerais foi a criação. Os animais eram soltos no campo, aproveitando-se a vegetação natural [...] Os mineiros não contavam com outra fonte de recursos além desta. O café, que vinha fazendo a fortuna de São Paulo, era na época, impraticável devido a distância e a dificuldade de transporte.

Apesar dos períodos de crise e prosperidade atravessados pela economia brasileira e pela economia paulista no fim do Império e no início da República, a expansão da frente pioneira era favorável aos precursores mineiros, advindos do grupo de pioneiros cafeicultores, entre 1880 e 1910.

A despeito das dificuldades, aos poucos se organizou uma modesta rede urbana e, no início do século XX, a expansão da cultura cafeeira veio mudar o perfil do extremo oeste do Planalto Ocidental, com seus espigões, onde os agricultores se beneficiariam do trabalho dos mineiros, “já [que] havia caminhos abertos, os índios quase todos dizimados ou escorraçados e alguns núcleos urbanos que serviam de ponto de apoio às plantações. A atividade de criação fornecia alimentação e animais de trabalho” (ABREU, op. cit. p. 25) 


\section{ESTADO SÃO PAULO - SUDOESTE \\ FIGURA 02 - A PENETRAÇÃO E A POSSE DOS MINEIROS NO VALE DO PARANAPANEMA EM MEADOS DO SÉCULO XIX}
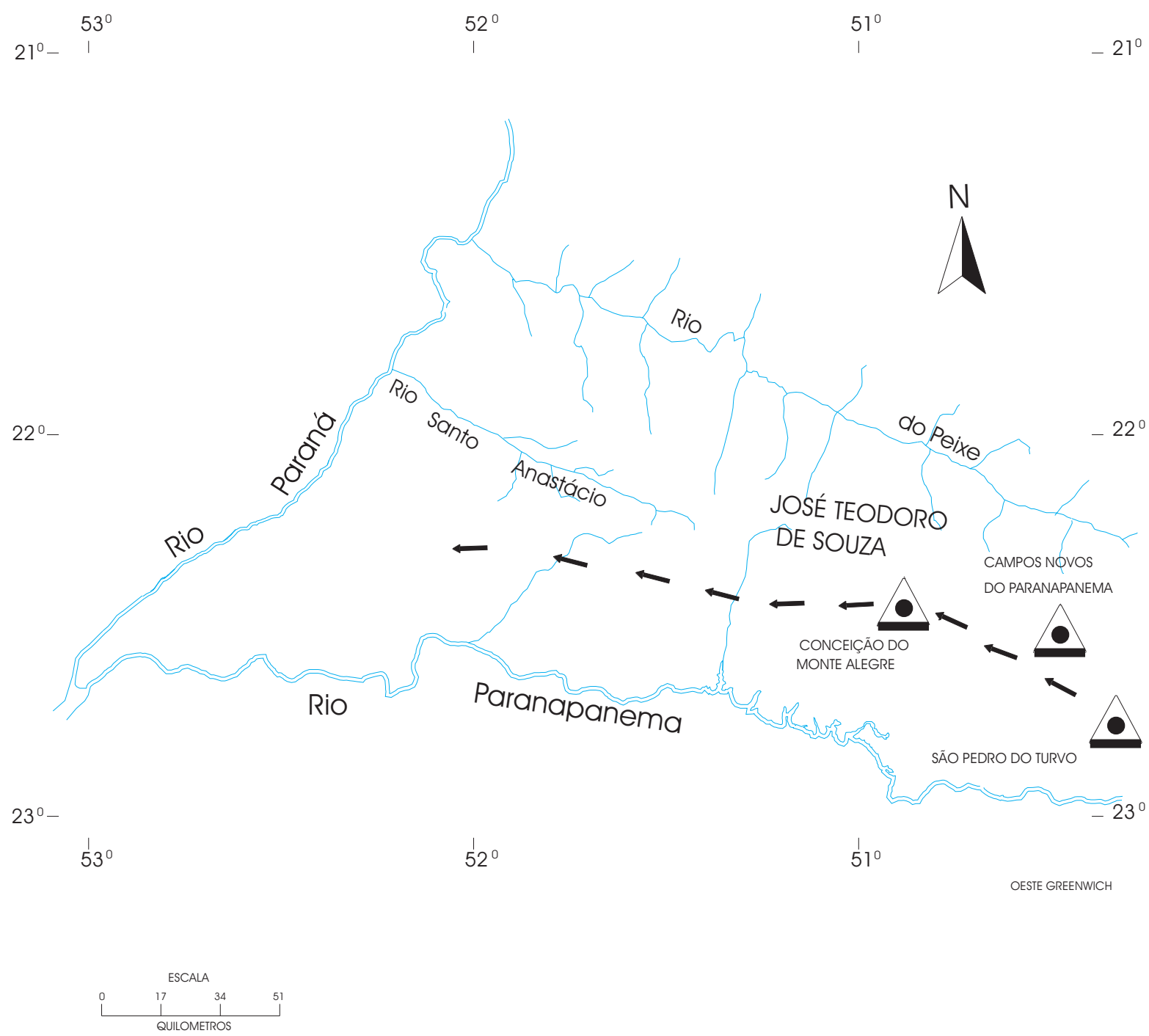

LOCALIZAÇÃO DA ÁREA

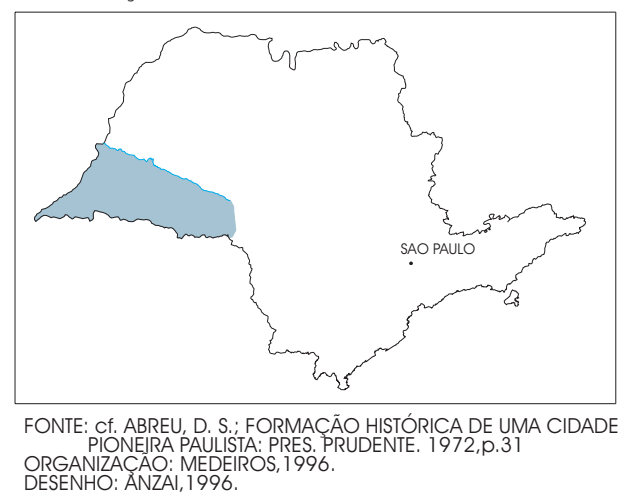

LEGENDA:

- CIDADES FUNDADAS POR

- JOSÉ TEODORO DE SOUZA

— PENETRAÇÃO MINEIRA 
Entretanto, não foi sem resistência que os precursores mineiros receberam os agricultores de café, dificultando a posse da terra. Mas essa resistência aos poucos foi diminuindo, através de negociações, demandando ou expulsando os antigos moradores.

A marcha de povoamento teve como principal impulso o transporte ferroviário, servido pela Estrada de Ferro Sorocabana, sendo que, em janeiro de 1919, foram inauguradas as estações de Presidente Prudente e de Regente Feijó.

A estruturação na forma de rosário, ditada pelas cidades ao longo da estrada de ferro, impõe-se com as empresas loteadoras e os proprietários cafeicultores se instalando próximos deste eixo. O futuro cafeicultor, "ao escolher sua terra evitava sempre os solos baixos dos vales, que canalizavam com facilidade os ventos frios e sujeitavam o cafezal ao perigo das geadas” (MONBEIG, 1957 p.107).

Enquanto isso, a atividade pecuária, baseada na grande propriedade, já se estabelecera nos vales e espigões dos afluentes dos rios do Peixe, Santo Anastácio e Paranapanema. (Figura 3)

A estrutura agrária, conforme Abreu (op. cit. p. 97), embora se reportando ao município de Presidente Prudente, “organizou-se não só em função da pequena propriedade resultante da política de venda de terras de Marcondes e Goulart, mas também em função de grandes latifúndios”, o que também caracteriza outras áreas da região.

Ao tratar das relações de produção na agricultura do Oeste paulista, Ianni (1981) descreve o contexto econômico-social, no qual o imigrante se transformou em colono, ou seja, um tipo especial de trabalhador que vende sua força de trabalho; as relações de produção basearam-se, assim, no regime de colonato. Embora esse estudo fosse sobre a cafeicultura, na região de Sertãozinho, podemos afirmar que o mesmo ocorreu na região de Presidente Prudente.

A coexistência do latifúndio com a pequena propriedade fica patente nos resultados de levantamentos realizados pelo Cartório de Registro de Imóveis ${ }^{57}$, onde, numericamente, os pequenos proprietários perdem em área possuída para os latifundiários.

Empréstimos facilitados pelos bancos estrangeiros aos grandes proprietários, a aparente prosperidade da cultura cafeeira, os solos férteis, a especulação com terras e a colonização de grandes áreas através de loteamento, formaram a conjuntura do

${ }^{57}$ Abreu, op.cit. p.97-8. 


\section{ESTADO DE SÃO PAULO - SUDOESTE \\ FIGURA 03 - O MUNICIIPIO DE PRESIDENTE PRUDENTE - 1921 \\ AREAS DE AGRICULTURA E DE PECUARIA \\ POR PREDOMINÂNCIA}
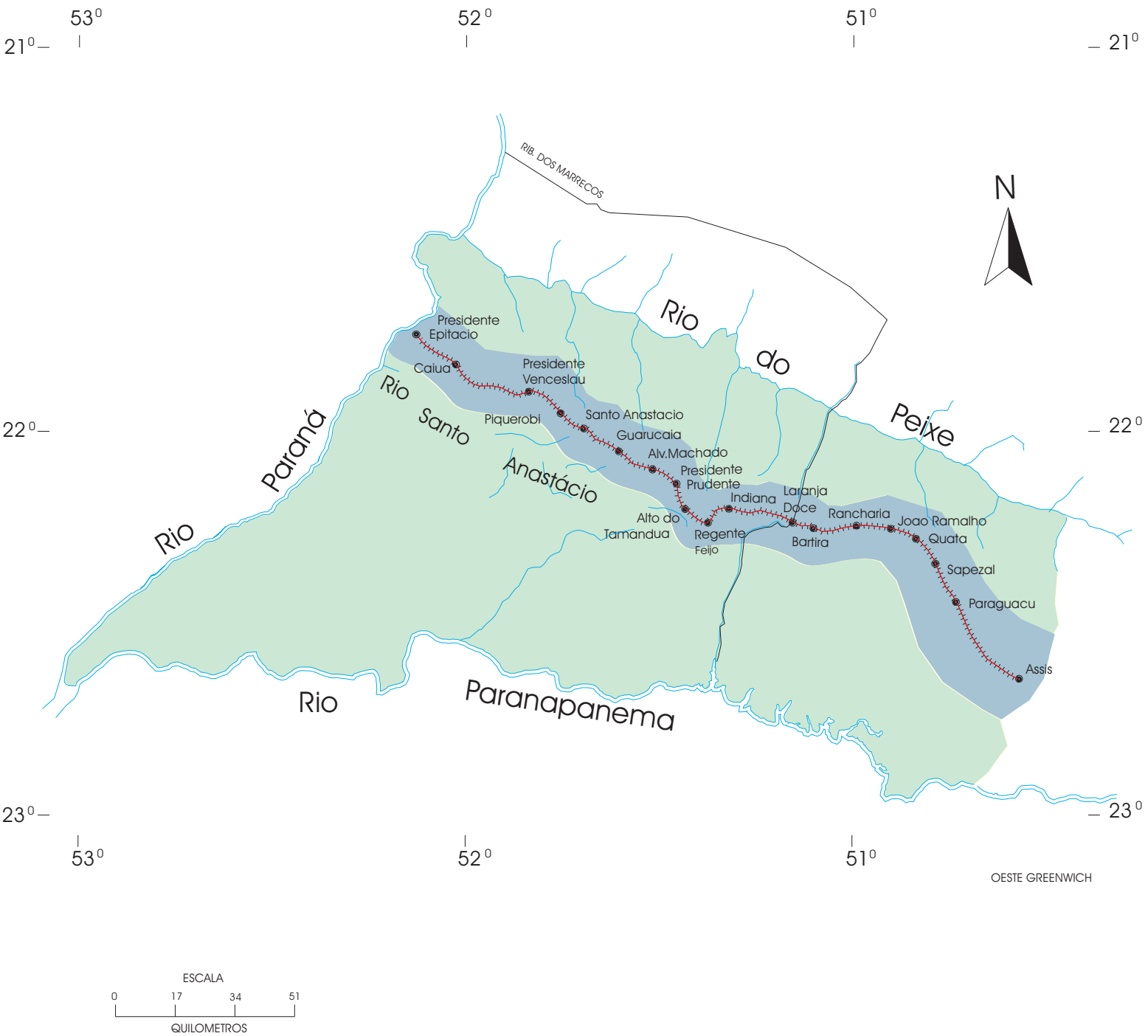

LOCALIZAÇÃO DA ÁREA

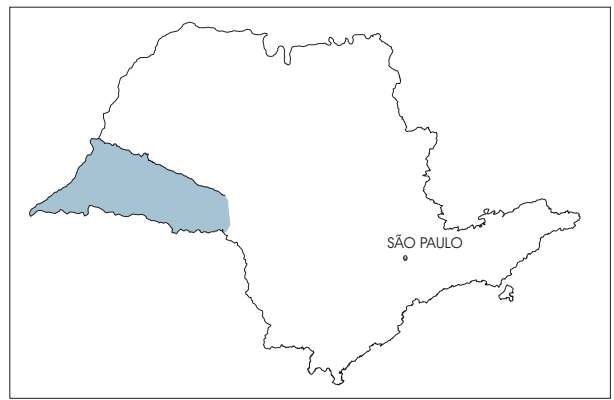

LEGENDA:

FONTE: Cf. ABREU, D. S.; FORMAÇÃO HISTÓRICA DE UMA CIDADE PIONEIRA PAULISTA: PRES. PRUDENTE. 1972, p.95 ORGANIZAÇAO: CELIA SANTOS MEDEIROS, 2002 DESENHO: ANZAI, 1996. 
povoamento do interior paulista e, conseqüentemente, da Alta Sorocabana ${ }^{58}$. Contudo, pequenos lavradores entrevistados por Abreu (op.cit. p.102), afirmaram que a produção agrícola não tinha financiamento bancário, portanto não contavam com eles.

“O movimento pioneiro paulista era cada vez mais um negócio mundial” (MONBEIG, op. cit. p. 112), e, apesar da crise cafeeira, com a superprodução do café, a marcha para o oeste não cessou; apenas deixou de ser exclusivamente "marcha do café" para ser, simultaneamente, “marcha da pecuária”, associando os cafezais às pastagens.

Assim, ao lado do café, nas décadas de 20 e 30; do algodão, a partir de 1922; e de culturas como arroz, feijão, milho, batata e cana, cultivados em estabelecimentos com áreas menores, sempre houve, entre os produtores rurais da Alta Sorocabana, um desvelo em formar pastos. Essa atividade não foi somente atributo de grandes proprietários, existindo também fazendas de criação que possuíam de 100 a 300, alqueires que associavam a atividade pecuária a alguma cultura de subsistência, e vendiam sua criação de pequeno número a açougueiros ou a compradores que trabalhavam para frigoríficos.

Segundo Abreu (op. cit. p. 137),

o núcleo urbano fundado para dar arrimo aos negócios de terra e a exploração agrícola vai paulatinamente suplantando a dependência que mantinha da zona rural do município para se constituir num centro comercial de beneficiamento de produtos agrícolas e de prestação de serviços de toda a Alta Sorocabana, desfrutando cada vez mais de foros de capital regional.

${ }^{58}$ Alta Sorocabana, conforme Abreu (op. cit 1972). 


\subsection{A EXPANSÃO DA ATIVIDADE PECUÁRIA NA REGIÃO DE PRESIDENTE PRUDENTE}

As terras desgastadas pelos cafezais antigos, impróprias para o algodão, um mercado consumidor avultado pelo crescimento da população urbana regional e pela capital do Estado, além de fatores externos vão delineando, a partir da década de 30, a tendência agro-pastoril da região. E, a partir de 1940, a criação de gado, ao lado do algodão, vai, definitivamente, substituir o café.

Transformar o cafezal deficiente, que já dava prejuízos, em pastagem foi visto como a solução mais econômica para o produtor rural.

Visando também resolver o problema da mão-de-obra, causado pela atração que a cidade exercia nos trabalhadores rurais, com os salários mais altos da indústria, a criação de gado oferecia mais vantagens do que a cultura do algodão.

Outro fator importante para explicar a expansão da atividade pecuária de corte no Planalto Paulista foi, segundo Monbeig (op. cit. p. 303), a facilidade encontrada pelos produtores rurais com relação ao crédito junto ao Banco do Brasil e ao Banco do Estado de São Paulo, que era mais acessível aos criadores do que aos lavradores.

Em 1940, a estrada de ferro transportava as primeiras boiadas engordadas na região para os frigoríficos de São Paulo, Sorocaba e Cotia, conforme Leite (op. cit. p.103), e cujo frete ferroviário era mais barato para transportar gado do que para transportar café.

O preço sempre alto do gado também atraía os produtores rurais, e a partir de 1942, a opinião corrente entre os fazendeiros era que a criação "protegia-os melhor do que o café contra eventuais prejuízos”.(MONBEIG, op. cit. p. 303)

As condições geográficas foram assim descritas por França (1960, p. 23), que relata o aspecto do relevo como "na grande área sedimentar e de expansão das eruptivas básicas refletem pouca movimentação do relevo.

Formas tabulares predominam e nenhum obstáculo importante se antepôs aos desbravadores e povoadores do planalto”; no aspecto climático, “o predomínio de condições tropicais, aparecem atenuadas com temperaturas mais brandas e pluviosidades mais bem distribuídas” (FRANÇA, op. cit. p. 32); e, dos solos, “as terras arenosas, originárias das camadas cretáceas da formação Bauru, no Planalto Ocidental foram enriquecidas pela 
decomposição e desagregação de material proveniente das eruptivas básicas” (FRANÇA, op. cit. p.37).

Eles demonstram o aproveitamento dos campos naturais, que consolidam os fatores que influenciaram a expansão da atividade pecuária na Alta Sorocabana, e, indissociados de fatores políticos e econômicos, transformaram os desbravadores paulistas em especialistas na engorda do gado.

Entretanto, pode-se afirmar concordando com Monbeig que, a criação de gado, muito mais do que atribuída pela natureza e pela tradição pastoril, resultou da estrutura econômica e social vigente ${ }^{59}$.

Os animais vinham de longas distâncias, de Mato Grosso, de Minas Gerais e de Goiás; chegavam aqui em péssimo estado, e tinham que esperar, muitas vezes, durante semanas até que as estradas estivessem em condições melhores ou que houvesse vagões disponíveis nas ferrovias.

Sendo assim, era necessário que o gado descansasse nas “invernadas” da região, menos expostas aos rigores da seca. Vindos pelo Porto Quinze de Novembro, os animais permaneciam nestas invernadas e campos, desde Presidente Epitácio até Assis, até serem embarcados para frigoríficos de São Paulo.

Abreu (op. cit. p. 136) relata que apesar da criação de novos municípios, a área de pastagens foi sempre aumentando. Os produtores rurais reservavam cada vez mais áreas para a criação. Na década de 40, a Alta Sorocabana contava com um rebanho de 350.000 cabeças (MONBEIG, op. cit. p. 307), ocupando o segundo lugar entre as zonas de criação da franja pioneira paulista.

\subsubsection{As pastagens}

Nos pastos que iam sendo formados, devido a insuficiência dos campos para suportar o rebanho bovino, plantava-se o capim Rhodes (Chloris gayama Kunth) e o Jaraguá (Hyparrhenia rufa).

${ }^{59}$ Cf. José Ferrari Leite. A ocupação do Pontal do Paranapanema (1981). 
Em 1931 surgiam as primeiras mudas de capim Elefante (Pennisetum purpureum Schum) e de Colonião, sendo que este último acabou sendo o mais utilizado nas pastagens por ter alta capacidade de engorda e suportar maior lotação da pastagem.

Para se formar um pasto ou uma invernada, a técnica era a mesma; derrubar a floresta onde ainda havia e, em seguida, plantar forrageiras ${ }^{60}$; durante dois anos plantavam algodão e, depois de queimadas as últimas plantas, a terra era transformada em pastagem. As sementes, então, eram plantadas ou eram utilizadas mudas dispostas a dois metros umas das outras.

No período das chuvas, elas cresciam rapidamente e os animais podiam entrar nas pastagens que ainda não estavam bem formadas. As queimadas eram uma prática comum, pois contribuíam para que os tufos de capim tivessem certa uniformidade.

Notava-se uma preocupação dos proprietários das grandes fazendas, segundo Monbeig (op.cit. p.309), em deixar as pastagens descansarem e preparar mudas para formar novas invernadas. E já havia, conforme o mesmo autor, interesse por parte dos criadores paulistas em buscar novas técnicas, pois conheciam as deficiências da criação nas regiões tropicais, como também a mediocridade das pastagens, que sofriam com a seca e o fogo, assim como a baixa lotação e a subnutrição dos animais.

O Pangola, o Jaraguá, o gordura e o Colonião estão entre os capins mais difundidos nas pastagens brasileiras. Esses capins, que exigem solos mais férteis, sustentaram a pecuária brasileira nos últimos 500 anos, pois chegaram nos navios negreiros juntos com os escravos.

Os três primeiros foram praticamente esquecidos pelos pecuaristas e pesquisadores, enquanto o Colonião foi sendo menos plantado, por ser muito exigente com relação à fertilidade do solo e de difícil manejo, principalmente nos períodos de seca prolongada.

Deste modo, eles cederam espaço a um capim rústico, produtivo, que se adapta bem em solos menos férteis, a Brachiária, que foi introduzida no Brasil em 1962, e que tomou conta do país.

A expansão das pastagens na região, em detrimento de culturas agrícolas, provocou preocupação junto ao poder público, com relação aos problemas sociais que

${ }^{60}$ Qualquer planta ou grão para a alimentação do gado (Aurélio p.305, 1975). 
poderiam advir da saída dos trabalhadores rurais para as cidades, acentuando o êxodo rural e o desemprego.

Entretanto, Leite (op. cit, p. 104-105), afirma que, “a extraordinária evolução das áreas de pastagens não provocou o colapso das lavouras [...], embora as invernadas tenham aumentado” de 1940 até 1967, em 123\%.

Observa-se através do Quadro 2, a evolução da área agrícola e de pastagens da década de 1940 a 1980. Leite (1972) reconhece que, embora houvesse aumento da área de pastagem e diminuição da população rural em algumas áreas, a Alta Sorocabana se manteve entre as regiões do Estado e do país que mais se destacaram na produção das principais plantas oleaginosas; e, com relação à criação de gado de corte e carnes frigorificadas tal fato se repete.

\section{QUADRO 2. EVOLUÇÃO DA ÁREA AGRÍCOLA E DE PASTAGENS}

DRA - PRESIDENTE PRUDENTE

\begin{tabular}{|l|c|c|c|c|}
\hline \multicolumn{1}{|c|}{ ANO } & $\begin{array}{c}\text { PASTAGEM } \\
\text { (ha) }\end{array}$ & $\begin{array}{c}\text { LAVOURAS } \\
\text { TOTAL (ha) }\end{array}$ & \multicolumn{2}{c|}{ LAVOURAS (ha) } \\
\hline 1940 & 172,974 & 227,995 & 65,778 & 162,217 \\
\hline 1950 & 410,542 & 338,221 & 39,242 & 298,979 \\
\hline 1960 & 718,392 & 314,547 & 27,684 & 286,863 \\
\hline 1970 & $1.221,994$ & 235,968 & 11,885 & 169,260 \\
\hline 1975 & $1.352,273$ & 182,601 & 13,341 & 191,060 \\
\hline 1980 & $1.306,457$ & 210,994 & 19,934 & 245,664 \\
\hline 1985 & $1.252,739$ & 259,215 & 13,551 & 137,244 \\
\hline $1995 / 96$ & $1.225,050$ & 146,283 & 9,039 & 2 \\
\hline
\end{tabular}

Fonte: IBGE - Censos Agrícolas de 1940, 1950, 1960 e Censos Agropecuários de Estado de São Paulo de1970, 1980, 1985, 1995/96.

Contudo, apesar da manutenção da produção agrícola e pecuária, com a elevação da produtividade, não se verificou um investimento de capital por parte destes produtores nos setores urbanos produtivos da região e, tampouco, houve a diminuição do êxodo rural e da concentração fundiária. 


\subsubsection{As raças do rebanho de corte}

O rebanho de corte era constituído na década de 60, na região da Alta Sorocabana, segundo Leite (1972, p. 106), por mestiços de raças zebuínas, sobretudo o Nelore; porém, podia-se encontrar também nas invernadas as raças Zebu-mocho, a Gir, a Indubrasil e a Guzerá.

O gado Zebu, natural das regiões tropicais dos continentes asiático e africano, foi a raça que melhor se adaptou às condições climáticas e edáficas. Nota-se que desde a introdução da raça zebuína, no fim do século XIX, no Triângulo Mineiro, houve mestiçagem com raças locais, o que produziu um animal magro, mas resistente aos parasitas dos campos naturais, o Caracu.

Data de 1930 a entrada do Nelore nas fazendas de gado de corte da média Sorocabana, segundo Santiago (1987, p. 161), o mesmo ocorrendo na Alta Sorocabana. O baixo rendimento do rebanho, entretanto, levava os criadores a buscar técnicas como inseminação artificial com genes de raças européias; na Alta Sorocabana, alguns produtores rurais pecuaristas se destacaram na seleção de bons reprodutores importados, e ocorreu um avanço nas décadas posteriores, com o cruzamento de raças tanto para corte como para leite.

\subsubsection{A indústria de carne bovina}

Em Presidente Prudente, na década de 1950/60, houve a instalação de alguns frigoríficos, acentuando-se o interesse pela criação e engorda de bovinos na Alta Sorocabana, atraindo as atenções de produtores rurais da região e de outras para essa cidade.

Reportando-se à história da indústria animal no Brasil, segundo Mamigonian (1976, p. 9), “O primeiro frigorífico brasileiro começou a funcionar em 1913, em Barretos”, tendo como objetivo abastecer o mercado paulistano, que contava com escassos abatedouros. E, na América Latina, já "nos fins do século XIX, companhias européias e americanas haviam se estabelecido na Argentina, com o objetivo de exportar carnes” (MAMIGONIAN, op. cit.). 
Com a I Guerra Mundial, essas mesmas companhias investiram no Brasil, pois o governo brasileiro estimulava investimentos neste setor, visando aumentar as exportações para compensar a queda do comércio do café.

Conforme Benites (1978, p. 3), “é preciso destacar o papel desempenhado pelo poder público, com leis e incentivos fiscais que favoreceram a expansão desta atividade industrial”; todavia, com relação ao Estado de São Paulo, tal fato só beneficiou os primeiros frigoríficos, sendo que a iniciativa privada não necessitou "de qualquer interferência supletiva do poder público neste setor com a construção dos estabelecimentos.” (BENITES, op. cit. p. 34).

Em 1923, os frigoríficos Armour e Wilson abriram estabelecimentos na Grande São Paulo e arredores, espaço de forte mercado consumidor e centro de comando, tanto para investimentos como de desenvolvimento tecnológico, ligados à pecuária. Desta forma, a Alta Sorocabana foi considerada por eles a área potencial de engorda para o gado bovino magro proveniente do Mato Grosso, pois esses frigoríficos haviam comprado terras de mata na década de 1920-30, para futuras invernadas.

Este fato levou, desta maneira as ferrovias paulistas e, nesse caso, a E. F. Sorocabana, a propiciarem o aparecimento de áreas de engorda entre o centro de criação, Mato Grosso, e os frigoríficos da capital paulista. Contudo, o transporte por ferrovia foi entrando em declínio, a partir de 1940, até que o transporte rodoviário de carnes frigorificadas para os grandes centros, São Paulo e Rio de Janeiro, foi facilitado pela conclusão do asfaltamento da Rodovia Raposo Tavares até Presidente Epitácio, na década de 1950/60, iniciando a descentralização da atividade frigorífica.

Segundo ressalta Benites (1995, p.354), houve campanhas organizadas pelos invernistas pela construção de estabelecimentos frigoríficos na Alta Sorocabana. Na disputa pela localização de unidades entre as cidades de Presidente Prudente e de Assis, de início, venceu o interesse dos grandes frigoríficos anglo-americanos em protelar a concorrência de estabelecimentos localizados no interior ${ }^{61}$, para, definitivamente, perderem espaço para novos e melhor aparelhados estabelecimentos nacionais, que já se localizavam perto das áreas de engorda ${ }^{62}$.

\footnotetext{
${ }^{61}$ Para aprofundamento sobre o tema confira Benites (1995).

${ }^{62}$ Cf. Informações atualizadas no Relatório PRODER-SEBRAE (1998, v.1)
} 


\subsection{A ATIVIDADE PECUÁRIA NA REGIÃO DE PRESIDENTE PRUDENTE}

A partir da década de 1950, a atividade pecuária de corte se amplia na região de Presidente Prudente, sobretudo devido à crise do setor agrícola, relacionada aos baixos preços alcançados pelas safras produzidas, principalmente de algodão e café, os quais eram regulados pelo mercado externo.

Em relação ao gado de corte, segundo dados técnicos da Fundação SEADE $\left(1988\right.$, p.26) ${ }^{63}$,

[...] As mudanças ocorridas no comércio e na produção [da bovinocultura], levaram a integração vertical na produção de alguns Estados, como Mato Grosso e Goiás, que assumem as características de centros de cria e recria. Em São Paulo, a ênfase dada é na engorda e abate em regiões próximas a esses Estados. [...] Em 1960, as DIRAs que mais se destacavam em participação no total de pastagens artificiais foram as do Oeste paulista, onde juntamente se desenvolveram e instalaram as grandes fazendas de engorda de gado de corte. [...] o rebanho se concentrou no Oeste do Estado: São José do Rio Preto participava com 16,5\% dos efetivos, Presidente Prudente com 13,4\%, Araçatuba, 18,8\% e Marília, 8,2\% , totalizando 56,9\% do rebanho paulista.

Observou-se assim, que a pecuária extensiva levou a um aumento das pastagens artificiais em áreas que eram antes utilizadas para lavoura, e mesmo através de desmatamento e da ocupação do Pontal do Paranapanema. Essa ocupação através de grandes propriedades reproduzia o caráter mais especulativo do que produtivo da pecuária extensiva, tanto regional, quanto do restante do território brasileiro.

Pode-se constatar, através do quadro 2, a evolução da área de pastagens na região de Presidente Prudente. Da década de 1940 até a de 1970, houve um aumento significativo na área de pastagens, que passou de 172,974 hectares para 1.221,994 hectares. Assim, desde a década de 1950, ela permanece dominante sobre a área agrícola que, em 1950, era de 338,221 hectares, e, em 1995/96, diminuiu para 146,283 hectares.

Nas áreas de pastagens, conforme o relatório PRODER - SEBRAE (1998), predominam os capins do gênero Brachiaria, que se adaptam bem a solos de baixa fertilidade;

${ }^{63}$ A Interiorização do Desenvolvimento Econômico no Estado de São Paulo, 1920-1980. Fundação SEADE (1988). 
contudo, possuem baixos valores nutritivos, limitando os ganhos de peso nos animais e, conseqüentemente, a produção, por área, de carne e de leite. A capacidade de lotação estimada, em unidade animal por hectare, no EDR de Presidente Prudente, foi de 1,08, quando a do Estado de São Paulo era de 1,18, conforme dados do LUPA-IEA (1995/6).

Para a análise de um período maior, a tabela 4 apresenta os dados da FIBGE para o índice de lotação das pastagens e efetivo bovino na Microrregião Geográfica de Presidente Prudente e do Estado de São Paulo, 1950-1995/95. Nela é possível observar-se o crescimento do rebanho bovino, sendo que esse aumento ocorreu devido, principalmente, às mudanças feitas pelos produtores nas fases criatórias, que foram sendo cada vez mais realizadas na própria região.

Porém, a possibilidade de adquirir mais áreas, isto é, de uma maior concentração fundiária, também deu aos produtores rurais pecuaristas a oportunidade de aumentar suas pastagens e seus rebanhos.

TABELA 4. ÍNDICE DE LOTAÇÃO DAS PASTAGENS E EFETIVO BOVINO NA MRG DE PRESIDENTE PRUDENTE E DO ESTADO DE SÃO PAULO, 19501995/96

\begin{tabular}{|c|c|c|c|c|c|c|c|}
\hline \multirow[b]{2}{*}{ Anos } & \multicolumn{3}{|c|}{ MRG DE PRESIDENTE PRUDENTE } & \multicolumn{3}{|c|}{ ESTADO DE SÃO PAULO } & \multirow{2}{*}{$\begin{array}{c}\text { MRG } \\
\text { Pres.Prudente/ } \\
\text { Est São Paulo } \\
\text { (\%) }\end{array}$} \\
\hline & $\begin{array}{c}\text { Efetivo bovino } \\
\text { (cabeças) }\end{array}$ & $\begin{array}{c}\text { Índice } \\
1950=100\end{array}$ & $\begin{array}{l}\text { Cabeças / } \\
\text { Hectares }\end{array}$ & $\begin{array}{l}\text { Efetivo } \\
\text { bovino }\end{array}$ & $\begin{array}{c}\text { Índice } \\
1950=100\end{array}$ & $\begin{array}{l}\text { Cabeças / } \\
\text { Hectares }\end{array}$ & \\
\hline 1950 & 388.336 & 100 & 0,9 & 5.721 .977 & 100 & 0,7 & 6,7 \\
\hline 1960 & 653.813 & 168 & 0,9 & 7.131 .024 & 124 & 0,7 & 9,1 \\
\hline 1970 & 1.028.164 & 264 & 0,8 & 9.110 .633 & 159 & 0,8 & 11,2 \\
\hline 1975 & 1.379 .809 & 355 & 1,0 & 11.451 .139 & 200 & 1,0 & 12,0 \\
\hline 1980 & 1.529 .774 & 393 & 1,1 & 11.685 .216 & 204 & 1,1 & 13,1 \\
\hline 1985 & 1.557 .007 & 400 & 1,2 & 12.210 .369 & 213 & 1,2 & 12,7 \\
\hline $1995 / 96$ & 1.672 .025 & 430 & 1,3 & 12.306.790 & 215 & 1,3 & 13,5 \\
\hline
\end{tabular}

Fonte: F.I.B.G. E. - Censos Agrícolas do Estado de São Paulo de 1950 e 1960; Censos Agropecuários do Estado de São Paulo de 1970, 1975, 1980, 1985 e 1995/96. 
Do efetivo rebanho bovino na Microrregião Geográfica de Presidente Prudente, segundo dados da FIBGE em 1995/6, 51,5\% encontravam-se em estabelecimentos de áreas superiores a 500 hectares; 27,0\% , naqueles de 100 a menos de 500 hectares; 21,5\%, em estabelecimentos com área inferior a 100 hectares. Acrescenta-se que, nos estabelecimentos dirigidos pelos proprietários, concentram-se 96,9\% do rebanho bovino, sendo que os arrendatários eram responsáveis por 1,9\%; os ocupantes por 0,9\% e os parceiros por $0,3 \%$.

Pode-se afirmar que as características da atividade pecuária bovina diferem entre os estabelecimentos de áreas até 100 hectares e os com áreas superiores a 100 hectares.

Nas propriedades com até 100 hectares, destacam-se aquelas dirigidas pelo produtor familiar que têm a atividade pecuária como secundária, já que não é possível obter maiores rendimentos em uma produção pecuária de corte de pequena escala. Desta maneira, o produtor familiar associa a atividade agrícola com um rebanho de gado misto, para corte e produção de leite, servindo mesmo como uma "poupança", no caso da necessidade de uma despesa inesperada.

Já para os grandes estabelecimentos, a pecuária significa a apropriação da renda e a garantia da propriedade privada da terra. Acrescenta-se que, na maioria das vezes, nos grandes estabelecimentos não são necessários muitos investimentos e o número de mão de obra empregada é pequeno.

Com relação às inovações e tecnologias adotadas pelos produtores, de acordo com o relatório PRODER - SEBRAE (1998, v. 1, p. 6), a pecuária na região administrativa de Presidente Prudente é marcada pela heterogeneidade tecnológica, desta maneira, “estabelecimentos modernos que empregam técnicas de manejo e rebanhos de alto padrão zootécnico, convivem com estabelecimentos que não fazem uso das tecnologias mais rudimentares, como adubação e rotação de pastagens”. E acrescenta que há uma tendência a mudanças, pois as propriedades que não avançarem no uso de tecnologia poderão fracassar economicamente.

No que diz respeito à pecuária de leite no Brasil, na década de 1960, (PIRES apud SEADE,1988, p.29), ela

[...] é uma atividade secundária da pecuária extensiva de corte, com produtividade média das vacas ordenhadas ficando a um quinto dos países com produção intensiva e mecanizada. A produção de leite sofre quedas 
sensíveis com as variações climáticas entre o inverno e o verão e que provocam redução das pastagens. No período não se aplicavam técnicas para amenizar ou mesmo eliminar o problema.

Assim, observa-se que a partir da década de 1960, com a diminuição das áreas agrícolas, há um aumento da produção de leite na região de Presidente Prudente. Isto pode ser explicado pelo fato de que muitos produtores passaram a se dedicar à pecuária leiteira, como uma forma de diversificar suas atividades.

\section{TABELA 5. EVOLUÇÃO DA PRODUÇÃO DE LEITE NA MRG DE PRESIDENTE PRUDENTE E ESTADO DO SÃO PAULO - 1950-1996 (em mil litros)}

\begin{tabular}{|c|c|c|c|c|c|}
\hline Ano & $\begin{array}{c}\text { MRG de Pres. } \\
\text { Prudente }\end{array}$ & $\begin{array}{c}\text { Índice } \\
1950=100\end{array}$ & $\begin{array}{c}\text { Estado de } \\
\text { São Paulo }\end{array}$ & $\begin{array}{c}\text { Índice } \\
1950=100\end{array}$ & \multicolumn{2}{c|}{$\begin{array}{c}\text { MRG de Pres. Prudente/ } \\
\text { Estado de São Paulo (\%) }\end{array}$} \\
\hline 1950 & 17.325 & 100 & 514.710 & 100 & 3,4 \\
\hline 1960 & 12.971 & 75 & 676.257 & 131 & 3,9 \\
\hline 1970 & 35.401 & 104 & 1.117 .143 & 170 & 3,8 \\
\hline 1975 & 56.329 & 225 & 1.468 .041 & 185 & 4,7 \\
\hline 1980 & 81.891 & 373 & 1.723 .610 & 234 & 4,6 \\
\hline 1985 & 82.618 & 377 & 1.810 .408 & 251 & 5,6 \\
\hline 1996 & 104.306 & 502 & 1.847069 & 259 & 3,1 \\
\hline
\end{tabular}

Fonte: F.I.B.G.E. Censos Agrícolas do Estado de São Paulo de 1950 e 1960; Censos Agropecuários do Estado de São Paulo de 1970, 1975, 1980 e 1985 e Pesquisa Pecuária Municipal de 1996.

Contudo, observa-se ainda que,

A produção de leite da região é um retrato do Brasil. Pequenos produtores, que retiram sua renda mensal desta atividade, convivem com médios e grandes produtores. Como ponto em comum, a exceção de alguns poucos produtores, todos consorciam a pecuária de leite com outras atividades agropecuárias, sobretudo culturas anuais, ou com a venda da força de trabalho para outras finalidades. Também guardando semelhança com o padrão de pecuária leiteira do Brasil, o rebanho tem baixa produtividade média, cerca de 2 litros / dia por vaca ordenhada, enquanto na Argentina, por exemplo, a produção por vaca ultrapassa os 20 litros diários. [...] Grande parte das propriedades é voltada para a produção mista, tendo o leite como atividade que garante o custeio da atividade de corte, uma vez que a renda é regular e bem distribuída ao longo do ano. (PRODER - SEBRAE, 1998, v. 1, p. 24) 
Ainda com relação à produção leiteira e a renda obtida é demonstrada no quadro 3, obtido através de dados da FIBGE e da $\operatorname{COOLVAP}^{64}$, presente no relatório PRODER - SEBRAE (1998), a importância social da atividade leiteira na região de Presidente Prudente, representada por 4380 produtores, ao mesmo tempo em que revela a baixa renda e produção mensal da atividade leiteira entre os produtores que retiram até 100 litros/dia.

QUADRO 3. PRODUÇÃO LEITEIRA E RENDA POR TIPO DE PRODUTOR

\begin{tabular}{|l|c|c|c|c|}
\hline ITEM & PEQUENOS* & MÉDIOS* & GRANDES* & TOTAL \\
\hline N $^{\circ}$ de produtores & 4.380 & 815 & 145 & 5.340 \\
\hline Participação n ${ }^{\circ}$ de produtores & $82 \%$ & $16 \%$ & $3 \%$ & $100 \%$ \\
\hline Produção (mil litros) & 63.954 & 47.594 & 37.183 & 148.731 \\
\hline Participação na produção & $43 \%$ & $32 \%$ & $25 \%$ & $100 \%$ \\
\hline Produção média diária (litros) & 40 & 160 & 704 & 79 \\
\hline Renda mensal por propriedade (em reais) & 300 & 1.200 & 5.280 & 593 \\
\hline
\end{tabular}

Fonte: F.I.B.G.E., 95/96 e extrapolação a partir de dados da COOLVAP.

* Obs: Pequenos: até 100 litros/dia

Médios: de 101 a 300 litros/dia

Grandes: acima de 300 litros/dia

Fica evidente que, $81 \%$ dos produtores produziam menos de 100 litros diários, e, apenas 3\%, acima de 300 litros diários. Entretanto, diante da tendência logística de transporte em caminhões tanque (a granel), exige-se a escala mínima de produção de 300-500 litros/dia, o que excluiria uma parcela relevante de pequenos produtores.

A COOLVAP tem buscado agrupar os pequenos produtores para viabilizar o transporte a granel; contudo, há pouca receptividade, devido à elevação dos custos de produção por parte dos produtores, na compra de resfriador para armazenar o leite.

Desta maneira, frente a essas mudanças, a COOLVAP tem buscado se adequar às exigências do mercado; contudo, conforme Hespanhol (2000, p.181),

Para esses pequenos produtores de leite, a continuidade na atividade depende de exigências técnicas da cooperativa, já que a produção de leite constitui-se, na maior parte das vezes, numa atividade complementar ao cultivo agrícola

\footnotetext{
64 A Cooperativa de Laticínios do Vale do Paranapanema é a responsável pela captação de 40\% da produção de leite na região de Presidente Prudente. Outros laticínios, Líder, Parmalat e Leco, são responsáveis por 20\%, e embora seja uma estimativa, o restante, ou seja, cerca de $40 \%$, é vendido informalmente.
} 
ou à pecuária de corte, não compensando em virtude da escala de produção, dispêndios econômicos com a introdução de inovações tecnológicas. No caso dos médios e grandes produtores, apesar da adoção de algumas melhorias tecnológicas como a inseminação artificial, o confinamento e a ordenhadeira mecânica, o preço final recebido pelo leite é insuficiente para cobrir os gastos elevados [...]

Pode-se observar, então, que, para a maioria dos produtores de leite não há motivo para implementar e adotar mudanças na forma com que vêm trabalhando até aqui, por outro lado também não conseguem aumentar seus ganhos.

Outra atividade que merece destaque regional, ao lado da pecuária bovina, é a avicultura de postura e de corte.

Desta forma, segundo a FIBGE (1995/6), a produção avícola estava assim distribuída: 39,7\% em estabelecimentos com áreas superiores a 500 hectares; 27,5\%, naqueles com área de 100 a menos de 500 hectares; e, 32,8\%, em estabelecimentos com área inferior a 100 hectares.

O efetivo de galinhas, galos, frangas, frangos e pintos somavam 3.062.651 cabeças em 1995/96, representando 1,8\% do total do Estado de São Paulo.

A produção se dá de forma dispersa na região; contudo, destaca-se o efetivo de frangos nos municípios de João Ramalho, com 24,3\%, e de Rancharia, com 44,8\%; podese inferir que esses números se devam à proximidade desses municípios com a região de Bastos, fornecedora da matéria - prima, ou seja, pintainhos e grãos, necessária à atividade avícola. Tanto para corte, como de postura.

Importante ressaltar que nesta atividade há um grande contingente de descendentes de imigrantes japoneses ligados à avicultura.

Observa-se, então, que a avicultura de postura na Microrregião de Presidente Prudente é realizada, principalmente, em propriedades pequenas, de descendentes de imigrantes japoneses, com intensiva ocupação de mão de obra e de investimentos.

Assim, como já demonstrado nesta pesquisa, a atividade pecuária é sob o aspecto econômico e fundiário dominante, porém a atividade agrícola mesmo secundária é importante para a dinâmica econômica e social da região porque representa fonte de renda e trabalho para os produtores familiares, arrendatários e parceiros, bem como a oportunidade de trabalho para a mão-de-obra assalariada, necessária nas diversas etapas do processo produtivo agrícola. 
Desta maneira, exporei a seguir as características da agricultura regional destacando a evolução da atividade agrícola e a área cultivada, a condição do produtor, bem como, o montante produzido, o volume e o valor da produção. 


\subsection{A ATIVIDADE AGRÍCOLA NA REGIÃO DE PRESIDENTE PRUDENTE}

Pode-se dizer que, concordando com Hespanhol (2000), com relação a sua importância econômica, a produção agrícola passou, na década de $1950^{65}$, a ter um papel secundário em relação à pecuária bovina de corte.

Contudo, as atividades agrícolas sempre tiveram um papel importante pois, através delas, muitas famílias ${ }^{66}$, que dela dependiam, puderam se reproduzir socialmente, assim como pela absorção de mão-de-obra da população da região que a atividade agrícola proporcionava.

Ao examinar, então, como se deu o desenvolvimento da agricultura na região, as análises de períodos mais longos são feitas através de dados da FIBGE, para a Microrregião Geográfica de Presidente Prudente, na qual estão contidos os municípios do EDR de Presidente Prudente, ou seja, a área de estudo desta pesquisa.

E, para as principais culturas por área cultivada de cada município pesquisado, trabalhei com os dados do LUPA, agrupados no anexo 2, que também estão representados nas figuras 4, 5 e 6 em mapas síntese.

Dentre as principais culturas, por área cultivada, dos municípios do EDR pode-se destacar a braquiária, a cana-de-açúcar, o milho, o algodão, o feijão, o amendoim, a bata-doce, a mandioca, o café, o eucalipto e a fruticultura de mesa. As frutas mais representativas, por área cultivada, são o abacate, o abacaxi, a laranja, a manga e a melancia.

Contudo, ao analisar os dados dos mapas sínteses e do anexo 2, observa-se que muitas outras culturas são plantadas na região. Na tabela 6, com dados da FIBGE, nota-se o crescente aumento das pastagens desde a década de 1960; percebe-se que, em 1980, elas representavam 78,9\%; e, em 1995/96, 81,7\%.

Em contrapartida, a utilização de terra com lavouras, permanentes e temporárias, que representavam, em 1960, 25,7\% da área, em 1980, ela era de 12,7 \% e em 1995/96, somente de $9,7 \%$.

\footnotetext{
${ }^{65}$ Ver Quadro 2.

${ }^{66}$ Colonos, parceiros, arrendatários.
} 
FIGURA 4 - PRODUÇÃO TOTAL DAS CULTURAS DE BRAQUIÁRIA, CANA DE AÇUCAR, MILHO E EUCALIPTO DO EDR DE PRESIDENTE PRUDENTE, SEGUNDO ÁREA PLANTADA ha
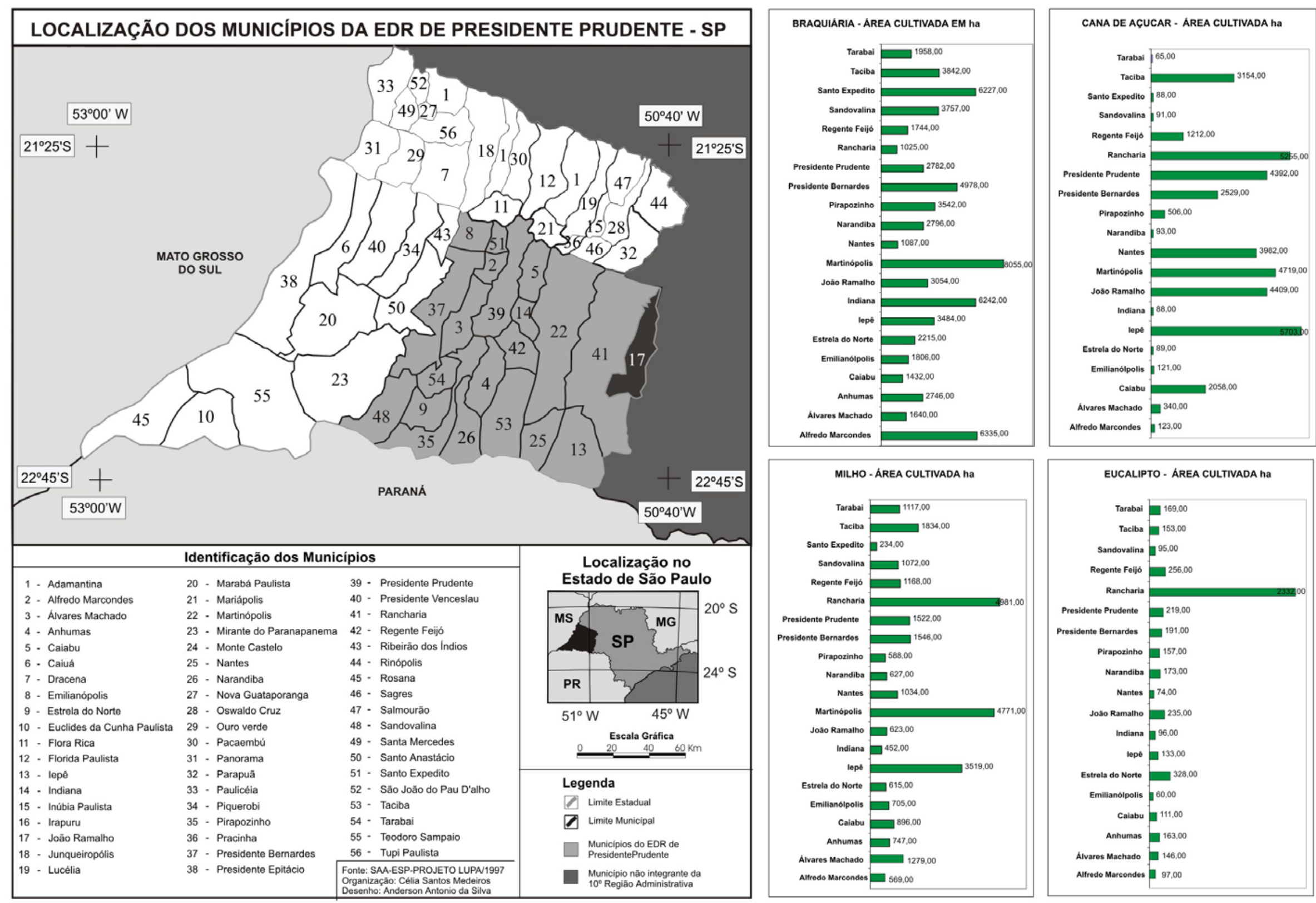
FIGURA 5 - PRODUÇÃO TOTAL DAS CULTURAS DE ALGODÃO, FEIJÃO, SOJA, SORGO E MELANCIA DO EDR DE PRESIDENTE PRUDENTE, SEGUNDO ÁREA PLANTADA ha
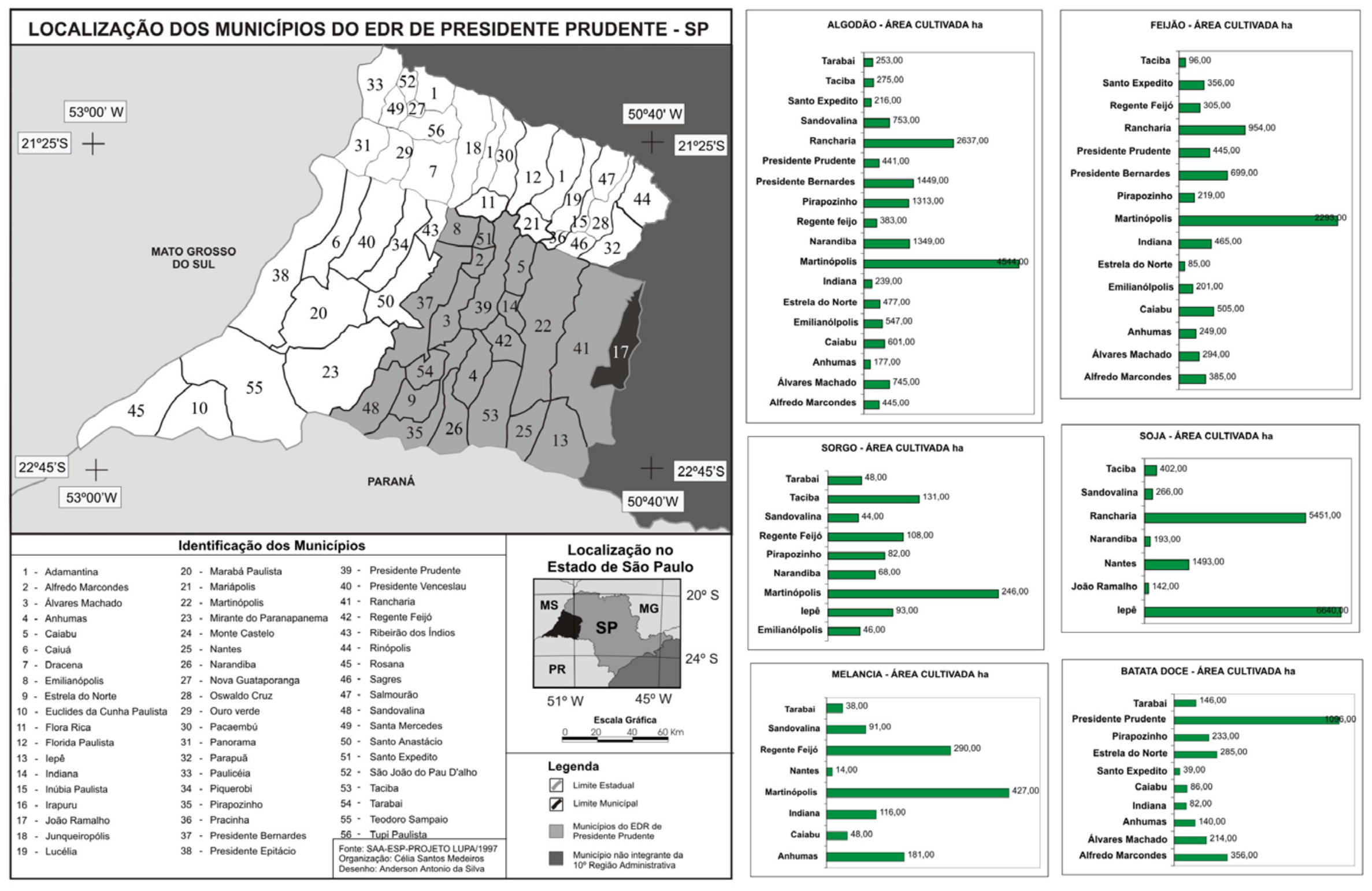
FIGURA 6 - PRODUÇÃO TOTAL DAS CULTURAS DE AMENDOIN, CAFÉ, CAPIM COLONIÃO, CAPIM NAPIER MANDIOCA, AMORA, SERINQUEIRA, ABÓBORA, TOMATE E OUTROS CAPINS DO EDR DE PRESIDENTE PRUDENTE, SEGUNDO ÁREA PLANTADA ha
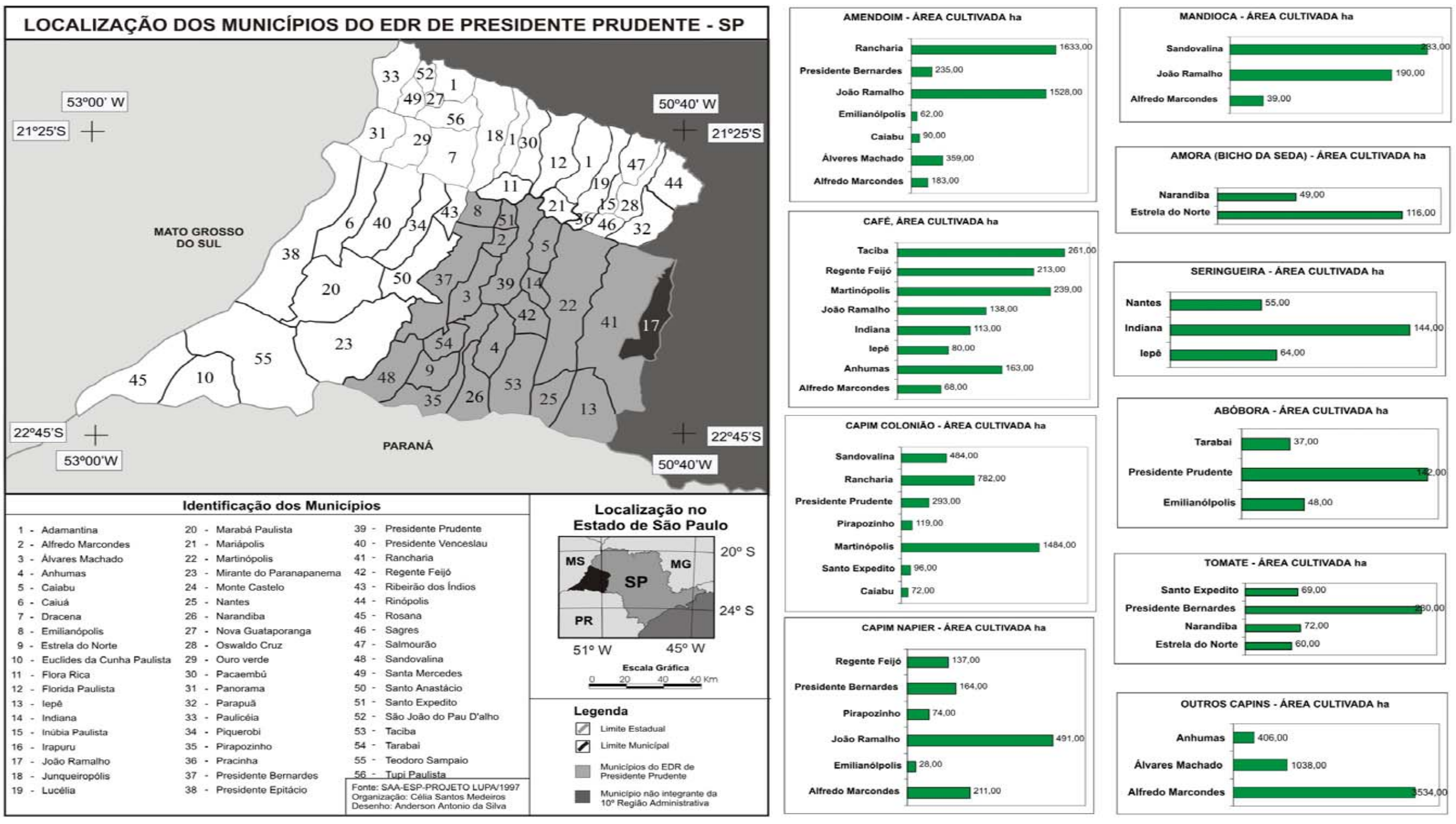
TABELA 6. UTILIZAÇÃO DAS TERRAS NOS ESTABELECIMENTOS AGROPECUÁRIOS DA MRG DE PRESIDENTE PRUDENTE 1950 - 1995/1996

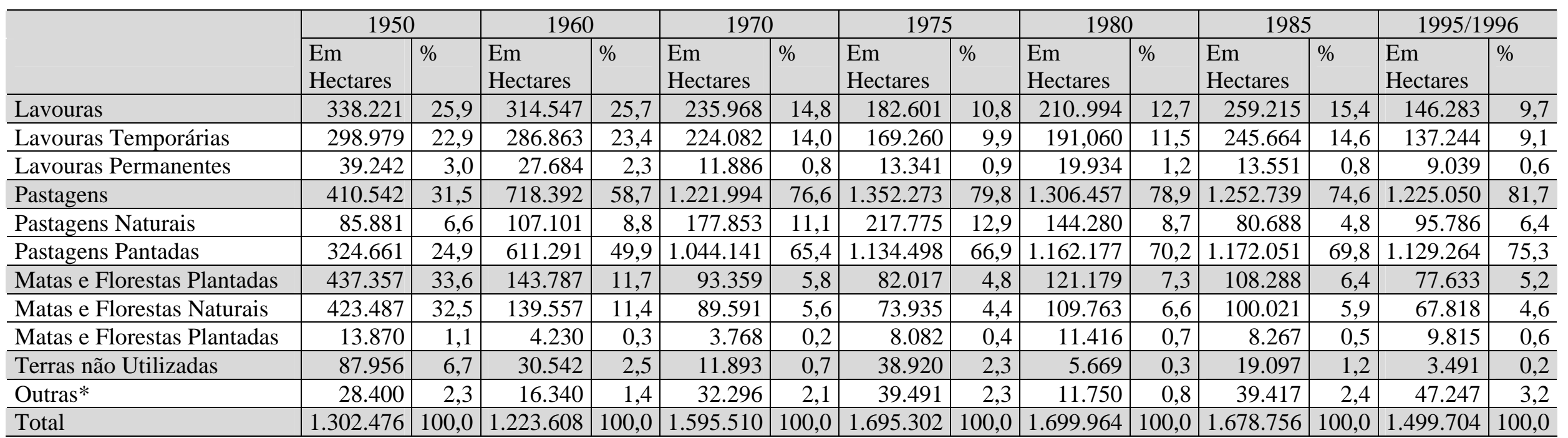

(*) Inclui terras não aproveitáveis.

Fonte: F. I. B. G. E. - Censos Agrícolas do Estado de São Paulo de 1950 a 1960; Censos Agropecuários do Estado de São Paulo de 1970, 1975 , 1980,1985 e 1995/1996. 
Desta maneira, conforme Dados Prudente-1998 (p.10-1), ocorreram distintas fases econômicas nesta região, desde a fase de extração da madeira, a da criação de gado, a fase do café (década de 1920-30), a do algodão (década de 1930-40), a da menta, a do amendoim e a do predomínio da criação pecuária de corte, até hoje.

CAFÉ - A fase do café foi muito próspera, trazendo para a região de Presidente Prudente, entre outras áreas do estado de São Paulo, um crescimento econômico acentuado, proporcionado pelos lucros da monocultura cafeeira; além disso, a necessidade grande de quantidade de mão-de-obra atraiu muitas pessoas, povoando esta área.

Entretanto, a partir do final dos anos 1920, ocorreu a decadência da monocultura cafeeira no Brasil, bem como na região de Presidente Prudente; ela foi provocada pela crise econômica de 1929, e fez com que os preços do café no mercado ficassem muito abaixo do desejado pelos produtores, tornando assim seu cultivo pouco atraente. Verificou-se, então, uma perda de importância econômica cada vez mais acentuada desta cultura; assim, desde a década de 1960, houve uma gradual erradicação dos antigos cafezais.

Ocorreu que, com a diminuição dos cafezais, trabalhadores rurais, ou seja, colonos e parceiros, que eram ocupados nas lavouras, migraram para as cidades; e, por outro lado, o acesso à terra cada vez mais limitado para os pequenos produtores, agravou o problema do êxodo rural, do desemprego e da exclusão social.

Cabe destacar que a cultura do café era produzida, principalmente, pela categoria de proprietários, e em estabelecimentos com área inferior a 100 hectares.

A cultura do café foi sendo, assim, substituída por outras atividades agrícolas; entre elas, destacou-se a da cultura do algodão, que já era cultivado, e torna mais expressiva a partir da década de 1930.

A partir de 1970, constata-se a diminuição da produção e da área cultivada com o café. E, em 1995/96, os dados da FIBGE mostram que havia apenas 1.458 hectares ocupados, e 78,7\% desta cultura concentravam-se em estabelecimentos com áreas menores que 100 hectares e, 21,3\% naqueles acima de 100 hectares. Os municípios de Anhumas, Martinópolis, Regente Feijó e Taciba totalizavam 58,1\% da produção regional.

Com relação ao valor total entre as outras culturas, o café representava 1,4\% desse total. Segundo a condição do produtor, 93,5\% das lavouras eram realizadas pelo proprietário; 3,1\% pelos parceiros; 2,1\% pelos arrendatários e 1,3\% por ocupantes. 
É possível comparar, através da tabela 7, quais culturas eram praticadas na década de 1970 e na década de 1990, segundo dados da Divisão Regional Agrícola de Presidente Prudente.

Dentre as mudanças na área cultivada e na produção agropecuária neste período, ressalta-se que a cana para indústria não era produzida em 1974/75, o mesmo se deu com a batata-doce. Essas culturas, embora tivessem finalidades comerciais diferentes e fossem realizadas por categorias diferentes de produtores, foram destaques na produção regional no levantamento realizado em 1995/96.

TABELA 7. ÁREA E PRODUÇÃO DAS PRINCIPAIS ATIVIDADES AGROPECUÁRIAS $1974 / 5$ e $1996 / 7$

\begin{tabular}{|c|c|c|c|c|c|c|}
\hline \multirow[b]{2}{*}{ CULTURA } & \multirow[b]{2}{*}{ ha } & \multirow{2}{*}{$\frac{1974 / 75}{\text { Produção }}$} & \multirow[b]{2}{*}{ Unid } & \multirow[b]{2}{*}{ ha } & $1996 / 97$ & \multirow[b]{2}{*}{ Unid } \\
\hline & & & & & Produção & \\
\hline Algodão & 32.613 & 23.007 & ton. & 5.578 & $8.600,70$ & ton. \\
\hline Amendoim & 57.060 & 2.954 .760 & SC & 5.540 & 408.580 & SC \\
\hline Feijão & 4.630 & 53.080 & $\mathrm{SC}$ & 7.672 & 106.172 & SC \\
\hline Milho & 35.722 & 871.485 & SC & 13.320 & 606.900 & SC \\
\hline Soja & 8.660 & 292.200 & $\mathrm{SC}$ & 9.962 & 399.130 & SC \\
\hline Batata-doce & - & - & cX. & 1.347 & 1.121 .200 & cX. \\
\hline Café & 5.008 & 123.072 & SC & 1.721 & 12.680 & SC \\
\hline Mandioca indústria & - & - & ton. & 960 & 19.200 & ton. \\
\hline Cana industria & - & - & ton. & 34.714 & 2.433 .200 & ton. \\
\hline Sericicultura & - & - & $\mathrm{kg}$ & 310 & 57.860 & $\mathrm{~kg}$ \\
\hline Seringueira & - & - & litro & 514 & 130 & litro \\
\hline Abacate & - & - & CX. & 355 & 30.000 & cx. \\
\hline Coco & - & - & & 78 & - & - \\
\hline Banana & - & - & ton. & 130 & 2.000 & ton. \\
\hline Goiaba & - & - & & 59 & 20.000 & cx. \\
\hline Maracujá & - & - & & 590 & 50.000 & CX. \\
\hline Abacaxi & - & - & CX. & 140 & 200.000 & $\mathrm{dz}$ \\
\hline Pastagem & 675.117 & - & & 710.619 & & \\
\hline Gado de Leite & $126.037 \mathrm{cab}$ & - & & $72.084 \mathrm{cab}$ & 56.056 .000 & litro \\
\hline Gado de Corte & $483.881 \mathrm{cab}$ & - & & $126.178 \mathrm{cab}$ & 29.262.838,24 & ton. \\
\hline
\end{tabular}

Fonte: Ano Agrícola DIRA-1974/5-1996/7 
Por outro lado, culturas que eram importantes em 1974/75, tiveram uma diminuição significativa tanto em área quanto em produção, como por exemplo o algodão, o amendoim e o milho.

Na tabela 8, estão relacionadas, por um período mais longo, as mudanças na produção das principais culturas na MRG de Presidente Prudente, bem como a área ocupada por cada uma delas. Podemos observar a produção e a área ocupada com as principais lavouras na Microrregião Geográfica de Presidente Prudente, no período de 1950-1995/96.

ALGODÃO - O algodão vai ser cultivado principalmente por arrendatários, em áreas de pecuária extensiva, para reforma das pastagens. A cultura do algodão proporcionou um impulso econômico para a região, principalmente com a introdução do algodão de fibra longa, que tinha preços atrativos no mercado internacional; houve, também, a instalação de indústrias para beneficiamento do produto.

Todavia, no período compreendido entre 1950-1975, com o aparecimento da fibra sintética, ocorre o declínio da cotonicultura. É importante citar, sem desprezar os fatores econômicos, que os solos, já utilizados pela cultura cafeeira, e que recebiam, na fase posterior, o algodão, são formados por arenito dos grupos Bauru e Caiuá, se apresentavam mais, enfraquecidos, sendo este um fator que, pode-se dizer, também contribuiu para a retração desta cultura.

Na década de 1970, a área cultivada com a cultura do algodão, era de 50.000 ha aproximadamente, segundo dados da SAA-CATI, e oferecia cerca de 16.000 empregos diretos, durante 5 meses por ano. Entretanto, observa-se que na safra de 1996/97, para os municípios do EDR, a área plantada era de 5.578 ha, reduzindo-se também a oferta de empregos a 1.600 no período. Buscando reativar esta cultura, a SAA do Estado de São Paulo desenvolveu um programa de bolsa de arrendamento para pequenos e médios produtores.

Nos anos 1980, houve uma recuperação da área plantada; contudo, não atingiu a área e a produção dos anos 1950. Desta forma, esta cultura foi economicamente viável até o início dos anos 1990, quando entra novamente em declínio devido a fatores como a importação de matérias primas pelo setor têxtil; o deslocamento desta atividade para o Centro - Oeste, mais favorável diante da possibilidade de produção mecanizada e em maior escala; e fatores biológicos (praga do bicudo). Da mesma maneira que o café, a cotonicultura era realizada em grande parte por proprietários e arrendatários, em estabelecimentos com área inferior a 100 hectares, segundo dados da FIBGE. 
TABELA 8. EVOLUÇÃO DA PRODUÇÃO E DA ÁREA OCUPADA COM AS PRINCIPAIS LAVOURAS NA MRG DE PRESIDENTE PRUDENTE, 1950 - 1995/1996

Produção em Toneladas

\begin{tabular}{|c|c|c|c|c|c|c|c|c|c|c|c|c|c|}
\hline Anos & Algodão & Amendoim* & Arroz & $\begin{array}{c}\text { Batata- } \\
\text { Doce }\end{array}$ & Café & $\begin{array}{c}\text { Cana-de- } \\
\text { açúcar }\end{array}$ & $\begin{array}{c}\text { Cana } \\
\text { Forrageira }\end{array}$ & Feijão** & Mamona & Mandioca & $\begin{array}{l}\text { Milho } \\
\text { Forrag. }\end{array}$ & $\begin{array}{c}\text { Milho } \\
\text { em } \\
\text { grão }\end{array}$ & Tomate \\
\hline 1950 & 142.739 & 12.621 & 11.163 & - & 18.555 & 3.818 & 68 & 4.850 & 587 & - & - & 45.033 & 203 \\
\hline 1960 & 128.197 & 72.440 & 4.136 & 104 & 16.123 & 4.732 & - & 1.237 & 102 & 2.620 & - & 19.193 & 476 \\
\hline 1970 & 78.166 & 136.731 & 7.381 & 97 & 2.379 & 29.891 & 8.396 & 1.618 & 9.280 & 7.009 & - & 33.122 & 1.332 \\
\hline 1975 & 37.439 & 55.671 & 13.604 & - & 14.173 & 7.739 & 17.424 & 1.667 & - & 4.356 & - & 56.751 & 13.969 \\
\hline 1980 & 37.698 & 48.005 & 4.329 & 452 & 14.651 & 841.113 & 96.719 & 11.084 & 6.263 & 10.832 & 6.850 & 31.546 & 56.851 \\
\hline 1985 & 89.871 & 32.082 & 3.300 & 933 & 12.011 & 2.267 .154 & 62.299 & 6.075 & 9.593 & 11.070 & 24.421 & 60.729 & 38.037 \\
\hline 1990 & 82.119 & 5.455 & 5.228 & - & 6.319 & 3.223 .657 & 201.950 & 23.831 & 12.271 & 19.900 & - & 64.749 & 20.000 \\
\hline 1995/1996 & 21.281 & 2.535 & 2.254 & 17.979 & 1.458 & 2.696.646 & 25.718 & 7.109 & 76 & 14.190 & 166.645 & 64.259 & 20.499 \\
\hline
\end{tabular}

Área (em ha.)

\begin{tabular}{|c|c|c|c|c|c|c|c|c|c|c|c|c|c|}
\hline Anos & Algodão & Amendoim* & Arroz & $\begin{array}{c}\text { Batata- } \\
\text { Doce }\end{array}$ & Café & $\begin{array}{c}\text { Cana- } \\
\text { de- } \\
\text { açúcar }\end{array}$ & \begin{tabular}{|c|} 
Cana \\
Forrageira
\end{tabular} & Feijão** & Mamona & Mandioca & $\begin{array}{l}\text { Milho } \\
\text { Forrag. }\end{array}$ & $\begin{array}{c}\text { Milho } \\
\text { em grão }\end{array}$ & Tomate \\
\hline 1950 & 177.009 & - & 14.838 & - & 31.364 & 139 & - & 10.626 & - & - & - & 38.570 & - \\
\hline 1960 & 129.045 & 46.284 & 3.479 & - & 21.009 & 141 & - & 2.822 & - & - & - & 19.030 & - \\
\hline 1970 & 82.819 & 121.712 & 7.493 & - & 6.381 & 373 & - & 4.396 & 33.071 & - & - & 33.071 & - \\
\hline 1975 & 40.391 & 48.981 & 12.208 & - & 8.582 & 348 & - & 3.918 & 41.589 & - & - & 41.589 & 2.822 \\
\hline 1980 & 33.579 & 34.490 & 4.692 & - & 14.103 & 15.198 & - & 23.789 & - & 889 & - & 47.282 & 2.103 \\
\hline 1985 & 62.118 & 19.339 & 2.758 & 115 & 9.516 & 37.671 & 1.476 & 12.181 & 11.099 & 965 & 1.705 & 35.544 & 1.307 \\
\hline 1990 & 69.229 & 3.340 & 3.801 & - & 3.911 & 51.659 & 4.790 & 42.971 & 8.763 & 920 & - & 34.760 & 585 \\
\hline $1995 / 1996$ & 18.015 & 1.490 & 1.358 & 3.010 & 1.261 & 40.476 & 949 & 11.461 & 143 & 1.275 & 15.105 & 26.951 & 698 \\
\hline
\end{tabular}

Fonte: F. I. B. G. E. - Censos Agrícolas do Estado de São Paulo de 1950 a 1960; Censos Agropecuários do Estado de São Paulo de 1970, 1975, 1980,1985 e 1995/1996 e Produção Agrícola Municipal de 1990.

(-) Dado não Disponível

* primeira e segunda safras

** primeira, segunda e terceira safras 
Em 1995/96, 63,3\% das áreas plantadas com algodão se localizavam em estabelecimentos menores de 100 hectares; e, 36,7\%, em estabelecimentos, acima de 100 hectares. Embora essa cultura esteja presente em toda a Microrregião, 50\% da produção estava assentada principalmente nos municípios de Martinópolis, Mirante do Paranapanema, Narandiba, Presidente Bernardes, Presidente Venceslau, Rancharia ${ }^{67}$ e Santo Anastácio.

Acerca do valor da produção, o algodão foi responsável por 9,0\% do valor total das culturas. Os arrendatários respondiam por 48,7\% do total da produção; os proprietários, por 45,7\%; e, os parceiros e ocupantes, respectivamente por 1,2\% e por 4,3\%.

Deve-se ressaltar que, juntamente com o algodão e outras atividades agrícolas, houve a continuidade da pecuária de corte na região, que mudou para uma fase mais comercial, ao contrário da época da colonização.

AMENDOIM - A cultura do amendoim também merece destaque, pois, segundo o Plano Diretor de Presidente Prudente - 1996, tal cultura "permitiu a região tornarse um dos maiores centros produtores do Brasil na década de 1960”. Um dos pontos favoráveis ao produtor era a possibilidade de se fazer duas colheitas anuais, e esta foi uma alternativa para as empresas processadoras de óleo que, instaladas na região desde a década de 1940, substituíram o óleo de algodão pelo óleo de amendoim.

Contudo, observou-se, a partir dos anos 1970, uma redução da produção e da área cultivada com amendoim, devido à disseminação da cultura da soja em outras regiões, bem como do aumento do consumo desse óleo, o que levou as empresas a, gradualmente, deixarem de processá-lo e, conseqüentemente, os agricultores de plantá-lo.

Segundo dados da FIBGE, os estabelecimentos de até 100 hectares, em 1995/96, respondiam por $81,5 \%$ do total de amendoim colhido na região, sendo que o estrato de menos de 20 hectares foi responsável por 41,3\% do volume produzido, dentro das áreas

67 Conforme o Relatório PRODER-SEBRAE (1998, v.2, p.47), as seis beneficiadoras que funcionavam em Presidente Prudente fecharam nos últimos anos. O maior produtor de Martinópolis, que tinha máquinas próprias, mudou-se para Sapezal, MS. Permaneceram firmas grandes, que tinham os segmentos de extração de óleo e fiação integrados verticalmente, como a Algodoeira Palmeirense S. A. e a Algoeste, ambas no município de Rancharia, ou firmas com amplas redes nas regiões produtoras dedicadas à comercialização do algodão em pluma, como a Brascotton, [...] que adquiriu diversas máquinas de beneficiamento na região e arrendou as instalações da Cooperativa de Cotia no município de Martinópolis. Por falta de matéria-prima, a capacidade ociosa na indústria é elevada (80\%); a Algodoeira Palmeirense empregava em 1998, 17 pessoas na fiação, mas, se funcionasse com a capacidade plena, demandaria 330 trabalhadores; no beneficiamento do algodão e na extração de óleo trabalham 103 pessoas; contudo, o emprego potencial nesse setor ultrapassa a cifra de 600 postos de trabalho. 
com menos de 100 hectares (81,5\%), e os estabelecimentos com áreas acima de 100 hectares, por 18,5\%. Os proprietários e arrendatários foram os responsáveis pela produção do amendoim na região, representando, respectivamente, 58,1\% e 30,1\% da condição de produtor.

Dentre os municípios produtores se destacam Álvares Machado, Alfredo Marcondes, Caiabu e João Ramalho que juntos significavam 54,8\%, nas duas safras anuais, produzidas na região. Entretanto, o valor da produção foi de apenas 0,7\% do total das culturas. Estas foram administradas principalmente pelos proprietários, perfazendo 58,1\%, seguidos pelos arrendatários, com 30,1\% e pelos ocupantes e parceiros, com, respectivamente, $8,5 \%$ e $3,3 \%$.

MILHO EM GRÃO - Outro destaque entre as culturas da região é o milho em grão, pois o mesmo serve tanto como complemento na alimentação do rebanho bovino, nos períodos de pastagem insuficientes ${ }^{68}$, como para comercialização. Ressalta-se que o cultivo do milho sempre esteve entre as lavouras de maior expressividade na região, sendo que, desde a década de 1950, sua produção era superior à do amendoim e a do café. Através dos dados, nota-se um crescimento no volume, produzido no período de 1950-1995/96, de 42,7\%; entretanto, a área plantada foi reduzida em 30,2\%, devido à introdução de outras forrageiras para o rebanho bovino.

Com relação à distribuição da produção de milho na região, por ser a atividade pecuária uma atividade exercida em todos os estratos de área, observa-se que, em 1995/96, estabelecimentos com áreas inferiores a 100 hectares representavam 38,4\% do volume produzido; aqueles acima de 1000 hectares, 20,7\%; os de 200 a 500 hectares, 15,6\%; os de 500 a 1000 hectares, 13,7\% e os de 100 a 200 hectares, 11,6\%. Distinguem-se, entre os municípios produtores, Martinópolis, Mirante do Paranapanema, Presidente Bernardes, Rancharia e Taciba, com 44,4\% do volume da produção de milho em grão.

No que diz respeito ao valor da produção, esta cultura representou $8,7 \%$ do valor da produção das principais culturas. Os proprietários foram responsáveis por 87,2\% do montante produzido, os arrendatários por 9,3\%, os ocupantes por 2,9\% e os parceiros por $0,6 \%$.

${ }^{68}$ Sobre alimentação de bovinos de corte ver Medeiros op. cit. (p. 67-74). 
TABELA 9. MRG DE PRESIDENTE PRUDENTE: VOLUME DA PRODUÇÃO AGRÍCOLA POR ESTRATO DE ÁREA , $1995 / 96$.

\begin{tabular}{|c|c|c|c|c|c|c|c|c|c|c|c|c|c|c|c|c|c|c|}
\hline \multirow[b]{2}{*}{ Produtos } & \multicolumn{2}{|c|}{$\begin{array}{l}\text { Menos de } \\
20 \text { ha }\end{array}$} & \multicolumn{2}{|c|}{$\begin{array}{c}20 \text { a menos } \\
\text { de } 50 \text { ha }\end{array}$} & \multicolumn{2}{|c|}{$\begin{array}{c}50 \text { a menos de } \\
100 \text { ha }\end{array}$} & \multicolumn{2}{|c|}{$\begin{array}{c}\text { Menos de } \\
100 \text { ha }\end{array}$} & \multicolumn{2}{|c|}{$\begin{array}{l}100 \text { a menos de } \\
200 \text { ha }\end{array}$} & \multicolumn{2}{|c|}{$\begin{array}{c}200 \text { a menos de } \\
500 \text { ha }\end{array}$} & \multicolumn{2}{|c|}{$\begin{array}{c}500 \text { a menos de } \\
1.000 \text { ha }\end{array}$} & \multicolumn{2}{|c|}{$\begin{array}{l}1.000 \text { ha } \\
\text { e mais }\end{array}$} & \multicolumn{2}{|c|}{ Total } \\
\hline & Produção & $\%$ & Produção & $\%$ & Produção & $\%$ & Produção & $\%$ & Produção & $\%$ & Produção & $\%$ & Produção & $\%$ & Produção & $\%$ & Produção & $\%$ \\
\hline Algodão & 4.021 & 18,9 & 5.286 & 24,8 & 4.164 & 19,6 & 13.471 & 63,3 & 2.311 & 10,8 & 3.171 & 14,9 & 1.253 & 5,9 & 1.084 & 5,1 & 21.281 & 100,0 \\
\hline Amendoim & 1.048 & 41,3 & 665 & 26,3 & 353 & 13,9 & 2.066 & 81,5 & 374 & 14,7 & 95 & 3,8 & - & - & - & - & 2.535 & 100,0 \\
\hline Arroz & 564 & 25,0 & 300 & 13,3 & 167 & 7,4 & 1.031 & 45,7 & 422 & 18,7 & 638 & 28,3 & 39 & 1,7 & 124 & 5,6 & 2.254 & 100,0 \\
\hline $\begin{array}{c}\text { Batata- } \\
\text { doce }\end{array}$ & 5.759 & 32,1 & 6.087 & 33,8 & 4.487 & 24,9 & 16.333 & 90,8 & 1.294 & 7,3 & 352 & 1,9 & - & - & - & - & 17.979 & 100,0 \\
\hline Café & 368 & 25,2 & 416 & 28,6 & 363 & 24,9 & 1.147 & 78,7 & 283 & 19,4 & 28 & 1,9 & - & - & - & - & 1.458 & 100,0 \\
\hline $\begin{array}{l}\text { Cana-de- } \\
\text { Açúcar }\end{array}$ & 20.017 & 0,7 & 21.876 & 0,8 & 22.146 & 0,9 & 64.039 & 2,4 & 65.593 & 2,4 & 233.638 & 8,7 & 458.572 & 17,0 & 1.874 .810 & 69,5 & 2.696 .646 & 100,0 \\
\hline $\begin{array}{c}\text { Cana } \\
\text { forrageira }\end{array}$ & 1.501 & 5,8 & 2.907 & 11,3 & 2.789 & 10,8 & 197 & 27,9 & 3.434 & 13,3 & 5.287 & 20,6 & 4.027 & 15,7 & 5.773 & 22,5 & 25.718 & 100,0 \\
\hline Feijão & 1.306 & 18,4 & 1.740 & 24,5 & 1.030 & 14,5 & 4.076 & 57,4 & 1.056 & 14,8 & 1.463 & 20,6 & 402 & 5,6 & 112 & 1,6 & 7.109 & 100,0 \\
\hline Laranja* & 5.339 & 35,5 & 3.875 & 25,4 & 1.781 & 11,8 & 10.995 & 72,2 & 1.389 & 9,2 & 1.190 & 7,7 & 1.080 & 7,1 & 577 & 3,8 & 15.231 & 100,0 \\
\hline Mamona & 57 & 73,1 & 01 & 1,3 & 20 & 25,6 & 78 & 100,0 & - & - & - & - & - & - & - & - & 78 & 100,0 \\
\hline Mandioca & 10.398 & 73,3 & 1.346 & 9,5 & 423 & 2,9 & 12.167 & 85,7 & 310 & 2,2 & 678 & 4,8 & 478 & 3,4 & 557 & 3,9 & 14.190 & 100,0 \\
\hline Manga* & 2.080 & 29,9 & 2.016 & 29,0 & 1.053 & 15,2 & 5.149 & 74,1 & 421 & 6,1 & 516 & 7,4 & 147 & 2,2 & 712 & 10,2 & 6.945 & 100,0 \\
\hline Maracujá* & 1.926 & 45,4 & 1.607 & 37,9 & 375 & 8,8 & 3.908 & 92,2 & 222 & 5,2 & 100 & 2,3 & 12 & 0,3 & - & - & 4.242 & 100,0 \\
\hline Melancia* & 871 & 9,4 & 4.253 & 45,9 & 2.357 & 25,5 & 7.481 & 80,9 & 1.295 & 14,0 & 472 & 5,1 & - & - & - & - & 9.248 & 100,0 \\
\hline $\begin{array}{l}\text { Milho em } \\
\text { grão }\end{array}$ & 7.043 & 10,9 & 9.075 & 14,1 & 8.576 & 13,3 & 24.694 & 38,4 & 7.482 & 11,6 & 10.052 & 15,6 & 8.749 & 13,7 & 13.282 & 20,7 & 64.259 & 100,0 \\
\hline $\begin{array}{c}\text { Milho } \\
\text { forrageiro }\end{array}$ & 2.832 & 1,7 & 5.564 & 3,3 & 6.673 & 4,0 & 15.069 & 9,0 & 11.433 & 6,8 & 13.133 & 7,9 & 3.540 & 2,1 & 123.470 & 74,0 & 166.645 & 100,0 \\
\hline Tomate & 6.960 & 33,9 & 8.350 & 40,7 & 2.952 & 14,5 & 18.262 & 89,1 & 729 & 3,6 & 08 & 0,1 & 1.500 & 7,2 & - & - & 20.499 & 100,0 \\
\hline $\begin{array}{l}\text { Uva para } \\
\text { mesa }\end{array}$ & 265 & 36,7 & 341 & 47,4 & 53 & 7,4 & 659 & 91,6 & 60 & 8,4 & - & - & - & - & - & - & 719 & 100,0 \\
\hline
\end{tabular}

(*) Quantidade em mil frutos, os demais produtos em toneladas.

Fonte: F. I. B. G. E. - Censo Agropecuário do Estado de São Paulo de 1995/96 
FORRAGENS - Milho e a cana para forragem também estão diretamente ligadas à atividade pecuária; desta forma, constata-se, através dos dados da FIBGE, no período 1980-1995/96, que o milho forrageiro apresentou um aumento de 2.332,7\% no volume de produção; e, com relação à área cultivada, houve um aumento de 785,9\%. O município de Presidente Bernardes teve destaque, com 75,1\% do volume produzido na região.

Acrescente-se que, com relação ao valor total das lavouras, o mesmo foi responsável por 3,0\%. Vale ressaltar que, conforme os dados analisados, o milho forrageiro é cultivado principalmente em estabelecimentos com área superior a 100 hectares, representando 91,0\%; e, que os com área superior a 1.000 hectares, foram responsáveis por $74,0 \%$ do volume produzido, sendo que a maior parte da produção do milho é originada em estabelecimentos conduzidos pelos proprietários, ou seja, 98,8\%.

CANA FORRAGEIRA - Em 1995/96, a cana forrageira foi responsável por $1,3 \%$ do valor total das lavouras, sendo que, do volume produzido, 27,9\% tinham como origem estabelecimentos com área inferior a 100 hectares; 22,7\%, naqueles com área superior a 1000 hectares; 20,6\%, nos de 200 a menos de 500 hectares; 15,7\%, em estabelecimentos de 500 a menos de 1000 hectares e 13,3\% de estabelecimentos com área entre 100 e menos de 200 hectares. Na produção da cana forrageira, neste mesmo período, as explorações conduzidas pelos proprietários representaram 99,2\%; por outro lado, os ocupantes representavam apenas $0,6 \%$ e, os arrendatários, $0,2 \%$.

MANDIOCA - Cultura que vem apresentando crescimento tanto em área quanto em produção; por conseguinte, os dados revelam que, no período compreendido entre 1975-1995/96, houve um crescimento da produção em 225\%. Tida usualmente como lavoura de subsistência, a mandioca é uma cultura que requer baixos investimentos, necessita de poucos cuidados por parte do agricultor e pode ser utilizada também na alimentação de animais, o que a torna uma alternativa para agricultores com menores recursos financeiros.

A expansão da mandioca na região se deve, também, conforme o PRODER/SEBRAE (1998), a fatores como a substituição da cultura do algodão, cujo preço se apresentava em queda na região; a presença de unidades processadoras de mandioca ${ }^{69}$, bem como a elevação dos preços recebidos pelos agricultores no Estado de São Paulo. Os

\footnotetext{
${ }^{69}$ Segundo Hespanhol (2000), o município de Sandovalina conta, desde os anos 1990, com uma fecularia e uma farinheira para processamento industrial da mandioca produzida na região, a COCAMP também possui uma, no município de Teodoro Sampaio, para processar a produção dos assentamentos rurais.
} 
estabelecimentos com área inferior a 100 hectares são responsáveis por 85,7\% da produção da região, sendo esta realizada principalmente pela categoria dos proprietários, que representam 87\%. Apesar da produção de mandioca estar distribuída por todos os municípios da região, os municípios de Euclides da Cunha, Mirante do Paranapanema, Rosana e Teodoro Sampaio somam $71,8 \%$ do total produzido.

FEIJÃO - O feijão, que é uma cultura adotada tanto para comercialização quanto para consumo, teve a partir do projeto PROOESTE ${ }^{70}$, nos anos 1980, um crescimento significativo, contudo irregular. Mas, nos anos 1990, houve uma diminuição tanto na área como na produção; mesmo assim, nos dados de 1995/96, ele foi o responsável por 4,6\% do valor da produção agrícola. A produção do feijão provém, 57,4\%, de estabelecimentos em estratos de área menores de 100 hectares; e, aqueles em áreas acima de 100 hectares, representavam $42,6 \%$ dela.

Na cultura do feijão, merecem destaque, por serem responsáveis por 46,7\% da produção total da região, os municípios de Caiuá, Martinópolis, Mirante do Paranapanema, Presidente Bernardes, Presidente Epitácio e Presidente Venceslau.

Com relação aos responsáveis pelo volume da produção do feijão, os proprietários representavam 55,1\%; os arrendatários, 37,5\%; os ocupantes e parceiros, 6,4\% e $1,0 \%$, respectivamente.

CANA-DE-AÇÚCAR - É uma cultura presente desde o processo de ocupação da região; contudo, sua importância econômica sofreu grandes transformações desde então. Assim, a cana-de-açúcar, no início da ocupação, era basicamente utilizada para subsistência, na produção de açúcar mascavo e rapadura; ela se transformou, em meados dos anos 1970, com o PROÁLCOOL, em uma atividade expressiva para a produção de combustível. Deste modo, em 1980, sua produção foi de 841.113 toneladas, em uma área ocupada de 15.198 hectares.

Na década de 1980, muitas destilarias foram implantadas na região, o que provocou uma expansão mais acentuada desta cultura, em áreas que eram utilizadas por pastagens, sendo que, entre 1980-1985, a produção ampliou-se em 169,5\% e, a área cultivada, em $147,8 \%$.

${ }^{70}$ O Governo do Estado de São Paulo, em 1979, instituiu através da Secretaria da Agricultura e Abastecimento, o Programa de Desenvolvimento do Oeste Paulista - PROOESTE. Sobre o assunto, consultar Ferreira \& Bray, 1984; e Hespanhol, 2000, p. 130-1. 
Cabe destacar que, neste período foi estimulada a produção de açúcar em detrimento do álcool combustível ${ }^{71}$; contudo, no período seguinte, 1990-1995, houve uma diminuição deste ritmo, devido, principalmente, à desregulamentação do setor sucroalcooleiro, à diminuição dos subsídios e aos baixos preços do álcool, levando à paralisação temporária da produção de algumas usinas e, mesmo, o posterior fechamento de empresas da região.

Entretanto, apesar dos fatores descritos acima, a cana-de-açúcar ainda representava, em 1995/96, 41,1\% do valor da produção agrícola da região.

Deve-se observar, entretanto, que as usinas, ao se instalarem, ofereceram oportunidade para que os produtores rurais pecuaristas pudessem arrendar suas terras, dandolhes um caráter mais "produtivo”, todavia esta oportunidade não foi estendida para todo o grupo dos produtores ${ }^{72}$, pois os dados de 1995/96 demonstram que 86,5\% da produção de cana são provenientes de estabelecimentos com áreas entre 500 e mais de 1000 hectares; e, aqueles com área inferior a 100 hectares foram responsáveis por apenas 2,4\% da produção.

Os arrendamentos e parcerias representavam $65,7 \%$ do volume total produzido, sendo que são as próprias usinas que fazem os arrendamentos nas proximidades da agroindústria, e a categoria dos proprietários, chamados de fornecedores, representam 34,2\% do total da produção.

Assim, como ressaltado por Hespanhol (2000, p.131),

[...] a implementação desses programas como o de Desenvolvimento do Pontal do Paranapanema e o PROOESTE, pelo governo estadual, ao direcionarem-se apenas para amenizar os problemas sociais decorrentes da falta de dinamismo econômico da Microrregião de Presidente Prudente, através da construção de usinas hidrelétricas ou do estímulo à expansão de determinadas lavouras, como a cana-de-açúcar, sem terem por objetivo, alterar a estrutura fundiária pré-existente e marcadamente concentrada, acabaram agravando a questão social na região.

${ }^{71}$ [...] em virtude da redução dos preços do petróleo no mercado internacional e da crise fiscal do Estado brasileiro, o governo federal passou a restringir a produção de álcool combustível, através da retirada de parte significativa dos incentivos até então concedidos e do estabelecimento de preços pouco remuneradores ao combustível renovável, provocando desestímulo à produção. A expansão da demanda e a elevação dos preços do açúcar no mercado internacional provocaram o direcionamento do processo produtivo, passando a ser estimulada a produção de açúcar em detrimento do álcool combustível. (Hespanhol, op.cit. p.130)

72 As usinas preferem arrendar ou ter como fornecedor aqueles estabelecimentos onde sejam mais viáveis o plantio, a colheita, a circulação de caminhões de transporte e próximos à agroindústria; além disso, elas mesmas preferem se responsabilizar pela organização do processo produtivo, pois, assim, detêm um melhor controle sobre toda a produção. 
TABELA 9.1. MRG DE PRESIDENTE PRUDENTE: VALOR DA PRODUÇÃO AGRÍCOLA POR ESTRATO DE ÁREA, 1995/96. (EM MIL REAIS)

\begin{tabular}{|c|c|c|c|c|c|c|c|c|c|c|c|c|c|c|c|c|c|c|}
\hline Produtos & \multicolumn{2}{|c|}{$\begin{array}{l}\text { Menos de } \\
20 \text { ha }\end{array}$} & \multicolumn{2}{|c|}{$\begin{array}{l}20 \text { a menos } \\
\text { de } 50 \text { ha }\end{array}$} & \multicolumn{2}{|c|}{$\begin{array}{c}50 \text { a menos } \\
\text { de } 100 \text { ha }\end{array}$} & \multicolumn{2}{|c|}{$\begin{array}{l}\text { Menos de } \\
100 \text { ha }\end{array}$} & \multicolumn{2}{|c|}{$\begin{array}{c}100 \text { a menos } \\
\text { de } 200 \text { ha }\end{array}$} & \multicolumn{2}{|c|}{$\begin{array}{c}200 \text { a menos } \\
\text { de } 500 \text { ha }\end{array}$} & \multicolumn{2}{|c|}{$\begin{array}{c}500 \text { a menos } \\
\text { de } 1.000 \text { ha }\end{array}$} & \multicolumn{2}{|c|}{$\begin{array}{l}1.000 \text { ha } \\
\text { e mais }\end{array}$} & \multicolumn{2}{|c|}{ Total } \\
\hline Amendoim & 89 & 39,3 & 186 & 25,3 & 130 & 17,8 & 605 & 82,4 & 97 & 13,1 & 33 & 4,5 & - & - & - & - & 735 & 00,0 \\
\hline Arroz & 33 & 28,3 & 58 & 12,4 & 27 & 5,8 & 218 & 46,5 & 84 & 17,9 & 122 & 26,0 & 12 & 2,5 & 33 & 7,1 & 469 & 100,0 \\
\hline $\begin{array}{l}\text { Batata- } \\
\text { doce }\end{array}$ & 715 & 32,9 & 708 & 32,5 & 515 & 23,6 & 1.938 & 89,1 & 187 & 8,6 & 50 & 2,3 & - & - & - & - & 2.175 & 100,0 \\
\hline $\begin{array}{l}\text { Cana-de- } \\
\text { Açúcar }\end{array}$ & 129 & 2,8 & 884 & 2,2 & 813 & 2,0 & 2.826 & 7,0 & 879 & 2,3 & 3.276 & 8,3 & 798 & 17,1 & 5.883 & 65,3 & 662 & 100,0 \\
\hline $\begin{array}{c}\text { Cana } \\
\text { forrageira }\end{array}$ & 19 & 16,5 & 155 & 11,7 & 70 & 5,2 & 44 & 33,4 & 101 & 7,7 & 332 & 25,0 & 299 & 22,6 & 149 & 11,3 & 1.325 & 100,0 \\
\hline 10 & & 2,7 & 03 & 3,5 & 654 & 2,1 & & 8,3 & 592 & 1,9 & 982 & 3,2 & 257 & 0,9 & 6.391 & 85,7 & & \\
\hline Laranja & 196 & 41,5 & 101 & 21,2 & 62 & 13,0 & 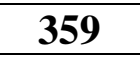 & 75,7 & 32 & 6,9 & 42 & 8,9 & 38 & 8,2 & 2 & 0,3 & 473 & 100,0 \\
\hline Melancia & 372 & 12,9 & 985 & 34,5 & 538 & 18,8 & 1.895 & 66,2 & 866 & 30,2 & 104 & 3,6 & - & - & - & - & 2.865 & 100,0 \\
\hline $\begin{array}{l}\text { Milho em } \\
\text { grão }\end{array}$ & 1.015 & 15,2 & 1.205 & 18,0 & 1.084 & 16,2 & 3.304 & 49,4 & 871 & 13,0 & 1.302 & 19,4 & 219 & 18,2 & - & - & 6.696 & 100,0 \\
\hline $\begin{array}{c}\text { Milho } \\
\text { forrageiro }\end{array}$ & 175 & 5,9 & 332 & 11,4 & 581 & 19,8 & 1.088 & 37,1 & 667 & 22,9 & 550 & 18,8 & 258 & 8,9 & 357 & 12,3 & 2.920 & 100,0 \\
\hline Tomate & 643 & 20,6 & 1.397 & 44,6 & 202 & 8,3 & $2.00<$ & (10, & 63 & 2,2 & 10 & 0,4 & 750 & 23,9 & - & - & 3.125 & 100,0 \\
\hline $\begin{array}{l}\text { Uva para } \\
\text { mesa }\end{array}$ & 246 & 34,9 & 371 & 52,7 & 52 & 7,3 & 669 & 94,9 & 37 & 5,1 & - & - & - & - & - & - & 706 & 100,0 \\
\hline
\end{tabular}

Fonte: F. I. B. G. E. - Censo Agropecuário do Estado de São Paulo de 1995/96. 
TOMATE - Uma outra cultura que se destacou na região a partir da década de 1970 foi o tomate; anteriormente produzido em pequena escala para consumo in natura, com a instalação, em 1974, da indústria CICA - Companhia Industrial de Conservas Alimentícias - passou a ser incrementada à produção do tomate rasteiro. A prática desta cultura também possibilitou aos proprietários de terras pecuaristas uma oportunidade para renovarem as pastagens, através do sistema de arrendamento.

Já no fim da década de 1970, a indústria processadora passou a pressionar os produtores para que estes seguissem um padrão de produção que elevasse o nível de produtividade, ou seja, irrigação e variedades específicas entre outras; selecionaram então, produtores com maiores recursos financeiros e que respondessem aos requisitos exigidos; isso impossibilitou que pequenos produtores continuassem nesta atividade. Entre 1975 e 1980, segundo dados da FIBGE, a produção de tomate ${ }^{73}$ aumentou em 306,9\%; contudo, a área cultivada teve uma redução de 25,5\%.

Esse quadro passou por mudanças em meados da década de 1980, quando problemas advindos da escassez de recursos para financiamento da produção, dos preços elevados dos arrendamentos e dos custos de transporte da produção, aliados a questões econômicas com o Grupo Bonfiglioli, detentor de grande parte das ações da CICA, levaram ao fechamento desta indústria em Presidente Prudente.

Houve, então, no período subseqüente, 1980-1995/96, tanto a redução da área cultivada em 66,9\%, como a do volume produzido em 64,0\%. Não obstante, o tomate continuou sendo produzido.

Entretanto, ocorreram mudanças no perfil do produtor e da produção; em 1995/96, 89,1\% da produção foram provenientes de estabelecimentos com áreas inferiores a 100 hectares, sendo que no estrato de 20 a 50 hectares estavam $40,7 \%$ do volume produzido, e, 10,9\% se distribuíam nos estabelecimentos com áreas superiores a 100 hectares.

Os municípios com produção mais significativa foram Álvares Machado, Martinópolis, Narandiba, Pirapózinho e Presidente Bernardes, com 65,9\% do total produzido na região. Mesmo com uma redução da área plantada, verificou-se, em 1995/96, que essa

\footnotetext{
73 Os dados da FIBGE relativos á produção do tomate envarado (para consumo in natura) e do rasteiro (para indústria) aparecem, juntos nos Censos.
} 
cultura representou 3,2\% do valor total da produção vegetal na região. Os arrendatários ${ }^{74}$ foram responsáveis por 59,5\% da produção, seguidos pelos proprietários, com 28,6\% e ocupantes, com 11,8\%.

Segundo Hespanhol (2000, p.161), "aproveitando-se dos equipamentos disponíveis como o aparelho de irrigação e da experiência adquirida na lavoura de tomate”, alguns antigos tomaticultores passaram a se dedicar ao cultivo do tomate envarado e ao da batata-doce, outros ainda, à produção de legumes e verduras para o abastecimento urbano.

BATATA-DOCE - A batata-doce, conforme os dados apontam, é uma cultura que vem ocupando uma área cada vez maior na região, por ser uma alternativa econômica para os pequenos e médios produtores ${ }^{75}$, principalmente os agricultores familiares, que substituíram culturas como o feijão, o algodão e o amendoim. Em décadas anteriores a de 1990, a produção da batata-doce se apresentava irregular e tinha pouca expressividade econômica, atendendo principalmente mercados regionais; contudo, apresentou, no decorrer deste período, um crescimento de $1.827,0 \%$.

Ressalta-se que esta cultura requeria investimentos baixos e apresentava condições favoráveis de comercialização, seja através do entreposto da CEAGESP ou de intermediários que pagavam preços compensadores.

Desta maneira, a produção de batata-doce se dava, principalmente, em estabelecimentos com área de até 100 hectares, que totalizavam 90,8\%, enquanto os estabelecimentos com área acima de 100 hectares representavam 9,2\%. A batata-doce era produzida, principalmente nos municípios de Álvares Machado, Pirapózinho e Presidente Prudente, somando 65,0\%; o restante estava distribuído pelos municípios da região.

A produção da batata-doce foi responsável por 2,2\% do valor total da produção agrícola regional neste período. Segundo a condição dos produtores, os proprietários respondiam por 74,6\% do volume da produção regional em 1995/96, e os arrendatários e ocupantes, por $17,4 \%$ e por $6,8 \%$ respectivamente.

ARROZ - A cultura do arroz pode ser considerada pouco significativa em termos de valor de produção, sendo de 0,5\% em 1995/96; contudo, com relação à condição do

\footnotetext{
74 Por ser uma cultura muito suscetível às pragas e doenças, é necessária uma rotação freqüente das áreas de cultivo, o que pode ser considerado uma outra razão da presença significativa de arrendatários.

75 Proprietários, arrendatários e parceiros.
} 
produtor, ela foi uma alternativa para os arrendatários, que conduziram $51,4 \%$ das explorações; os proprietários, 37,5\%; os ocupantes, 10,7\%; e, os parceiros, 1,0\%.

Quanto ao volume produzido por estrato de área, os estabelecimentos com área inferior a 100 hectares foram responsáveis por 45,7\% do volume regional, em que se destacaram aqueles com menos de 20 hectares, com 25,0 \% da produção. O município de Rosana foi representativo no volume da produção de arroz, detendo 57,6\% da produção regional.

Observa-se através dos dados da FIBGE, que a região de Presidente Prudente apresentou um aumento na produção de frutas desde a década de 1980.

A fruticultura foi apontada, segundo o relatório PRODER-SEBRAE (1998), como adequada a pequenas se médias propriedades rurais, conforme se pode observar nas análises que se seguem.

Destaca-se, a seguir, as principais frutas cultivadas na Microrregião Geográfica de Presidente Prudente, ou seja, os estratos de área, os principais municípios produtores, o valor da produção, bem como a condição do produtor.

TABELA 10. ÁREA E PRODUÇÃO DAS PRINCIPAIS FRUTÍFERAS NA MRG DE PRESIDENTE PRUDENTE, 1980 - 1995/96

\begin{tabular}{|c|c|c|c|c|c|c|c|c|c|c|}
\hline & \multicolumn{2}{|c|}{ MELANCIA } & \multicolumn{2}{c|}{ MANGA } & \multicolumn{2}{c|}{ UVA } & \multicolumn{2}{c|}{ LARANJA } & \multicolumn{2}{c|}{ MARACUJÁ } \\
\hline Ano & $\begin{array}{c}\text { área } \\
\text { (ha) }\end{array}$ & $\begin{array}{c}\text { Produção } \\
\text { (mil } \\
\text { frutos) }\end{array}$ & $\begin{array}{c}\text { área } \\
\text { (ha) }\end{array}$ & $\begin{array}{c}\text { Produção } \\
\text { (mil } \\
\text { frutos) }\end{array}$ & $\begin{array}{c}\text { área } \\
\text { (ha) }\end{array}$ & $\begin{array}{c}\text { Produção } \\
\text { (ton.) }\end{array}$ & $\begin{array}{c}\text { área } \\
\text { (ha) }\end{array}$ & $\begin{array}{c}\text { Produção } \\
\text { (mil } \\
\text { frutos) }\end{array}$ & $\begin{array}{c}\text { área } \\
\text { (ha) }\end{array}$ & $\begin{array}{c}\text { Produção } \\
\text { (mil } \\
\text { frutos) }\end{array}$ \\
\hline 1980 & n.d. & 1860 & n.d. & 1.421 & 89 & 321 & 16 & 1.213 & n.d. & 5.831 \\
\hline 1985 & n.d. & n.d. & 78 & 2.220 & 70 & 307 & 17 & 1.782 & 96 & 11.631 \\
\hline 1990 & 982 & 3.501 & 39 & 939 & 29 & 642 & 127 & 6.737 & 3 & 120 \\
\hline $1995 / 96$ & 1.676 & 9.248 & 476,6 & 6.945 & 103,4 & 719 & 466,5 & 15.231 & 85,5 & 4.242 \\
\hline
\end{tabular}

Fonte: F.I.B.G. E. - Censos Agropecuários do Estado de São Paulo de 1980, 1985 e 1995/96; Produção Agrícola Municipal de 1990.

(*) n.d. - não disponível 
MELANCIA - A melancia vem sendo cultivada na Microrregião de Presidente Prudente, como se observa na tabela 10, principalmente em estabelecimentos com estrato de área menores que 100 hectares, que representou em 1995/96, 80,9\% da produção regional.

Já nos estabelecimentos com áreas de 20 a menos de 50 hectares, ela somou 45,9\%; e, nas áreas superiores a 100 hectares, representou 19,1\%. Quanto a sua distribuição espacial, essa cultura temporária foi cultivada principalmente nos municípios de Martinópolis, Rancharia e Regente Feijó, que somaram 52,0\% do total regional.

A produção de melancia foi responsável por 2,9\% do valor da produção total da região. Os arrendatários, conforme a condição de produtor, foram responsáveis por 71,3\% das lavouras de melancia, seguidos pelos proprietários, com 26,4\% e pelos ocupantes, com $2,3 \%$.

MANGA - Outra frutífera que destaco é a manga, produzida na safra de 1995/96, em 74,1\% dos estabelecimentos, com estratos de área inferiores a 100 hectares e em 25,9\% naqueles com áreas superiores a 100 hectares. Essa cultura permanente se distribuía espacialmente pela quase totalidade dos municípios da região, com exceção do município de João Ramalho.

Desta forma, Álvares Machado, Presidente Prudente, Regente Feijó e Santo Anastácio representaram 51,3\% do total da produção da região. Os estabelecimentos administrados pelos proprietários representaram 96,0\% da produção da manga, enquanto os ocupantes, os arrendatários e os parceiros responderam por 2,3\%, 1,6\% e 0,04\%, respectivamente.

UVA-DE-MESA - A produção de uva de mesa, que é uma cultura permanente, foi também significativa, destacando-se nos estabelecimentos com áreas inferiores a 100 hectares; representaram a produção de 91,5\% da produção total da região, sendo que os demais estabelecimentos, em estratos de área acima desta dimensão, somaram somente $8,3 \%$.

A produção estava concentrada nos municípios de Álvares Machado, Alfredo Marcondes e Presidente Bernardes, que representaram 55,8\% da produção, totalizando $0,7 \%$ do valor da produção agrícola regional. Os produtores proprietários significaram 95,0\%, os arrendatários, 3,5\% e os parceiros, 1,5\% da produção. 
LARANJA - Outra cultura que apresentou um aumento em produção e em área foi a da Iaranja. Essa cultura permanente, embora pouco significativa no contexto da produção estadual (0,02\% em 1995/96), representa também uma opção para os produtores familiares. Deste modo, a produção dessa cultura atingia, no período citado, 72,2\%, em estabelecimentos com área inferior a 100 hectares; e, os estabelecimentos com área superior representavam $27,8 \%$.

Com relação aos municípios produtores mais significativos destacam-se Álvares Machado, Caiuá, Euclides da Cunha, Martinópolis, Presidente Prudente e Regente Feijó, embora a produção ocorra em toda a região.

A laranja representou, no valor de produção, 0,5\% da produção regional agrícola. Os responsáveis pela produção na região foram principalmente os proprietários, com $97,2 \%$ do volume produzido, seguidos pelos ocupantes e pelos arrendatários, com 2,2\% e $0,4 \%$, respectivamente.

MARACUJÁ - O maracujá é também outra frutífera cultivada na Microrregião de Presidente Prudente, cultivada em 1995/96, principalmente em estabelecimentos com área inferior a 100 hectares, sua produção que significou 92,2\% do volume total cultivado; ressaltando-se aqueles com menos de 20 hectares, com 45,4\%; os demais estabelecimentos, ou seja aqueles com áreas superiores a 100 hectares, representaram a soma de $7,8 \%$.

Os municípios de Álvares Machado, Presidente Bernardes, Presidente Epitácio e Martinópolis concentraram 55,5\% do cultivo do maracujá. Com relação ao valor da produção, essa fruta significou, $0,3 \%$ do valor da produção agrícola. Com respeito à condição do produtor, os proprietários representaram 58\%, os ocupantes, 26\%, os arrendatários 9,6\% e os parceiros $5,5 \%$.

Após a exposição dos dados sobre a fruticultura, pode-se afirmar que ela representa uma atividade que consegue agregar valor e renda para os produtores e para a região; entretanto, de acordo com o relatório PRODER-SEBRAE (1998, v.2) ${ }^{76}$, existem alguns limitantes para a expansão dessa atividade.

\footnotetext{
76 Segundo esse mesmo relatório, o CEAGESP (centro de comercialização local) é um pólo caracterizado intensamente pela importação (de outras regiões) de produtos agrícolas; desta maneira, a população da região é pouco abastecida pela produção regional, antes o é pela importação de frutas, legumes e verduras.
} 
Dentre eles, ressalta-se o problema decorrente da deficiente comercialização; assim, a possibilidade de expansão dos mercados e a diversificação de produtos são variáveis tidas como importantes para a consolidação da fruticultura regional.

E, com relação à produção agrícola regional para os produtos destacados aqui, pode-se dizer que todos eles são importantes para a dinâmica social, através da geração de renda e trabalho, bem como para a economia regional.

Embora, a produção animal represente $63,7 \%$ do valor total produzido na região e a produção vegetal 36,3\%, nos estabelecimentos com áreas menores que 100 hectares dirigidos principalmente por produtores familiares, pode-se vislumbrar as possibilidades dessas áreas se os produtores conseguirem superar restrições como, pouca capacitação técnica; falta de organização da oferta, seja por meio de associações e/ou cooperativas; uma política de investimentos mais adequada e uma estrutura de comercialização mais conveniente. 


\title{
CAPÍTULO 7 - O PRODUTOR FAMILIAR DA REGIÃO DE PRESIDENTE PRUDENTE
}

\author{
7.1. A DINÂMICA SOCIAL DO ESPAÇO RURAL DO SUDOESTE PAULISTA - ANOS 80- \\ 90
}

No capítulo anterior, demonstrou-se como se deu o processo histórico de ocupação do espaço rural desta região, bem como se analisou, a área ocupada e a produção das principais atividades agropecuárias, e o valor da produção em período mais recente. Desta maneira, este espaço foi ocupado de um lado, pela grande propriedade pecuária, e, de outro, por aquelas propriedades menores, ocupadas principalmente por culturas que variaram conforme as vantagens econômicas e as de mercado, de cada período já mencionado neste trabalho.

Assim, fatores tais como empréstimos bancários, fossem eles para os produtores rurais pecuaristas e / ou para os agricultores; a aparente prosperidade das culturas, fossem elas para o mercado externo ou interno; solos férteis; a especulação com terras e a colonização de grandes áreas através de loteamento, formaram a conjuntura do povoamento do interior paulista e conseqüentemente, da Alta Sorocabana ${ }^{77}$.

Constatou-se que os incentivos econômicos, as ações políticas e os conseqüentes avanços sociais não alcançaram, desde então, de forma eqüitativa, a totalidade dos produtores rurais da região, fato que se verificou também no nível estadual e no nacional.

Observou-se que, apesar das desigualdades de oportunidades entre aqueles produtores que não se enquadravam nestes grupos mais privilegiados, estes atores têm conseguido permanecer na atividade agropecuária, mesmo com todo tipo de limitações.

Detêm os seus meios de produção, embora com uma renda, às vezes aquém de suas necessidades de reprodução, e têm sua produção e seu trabalho dominados pela lógica do mercado.

${ }^{77}$ Abreu, op. cit, 1972. 
Os produtores rurais pecuaristas residentes em Presidente Prudente foram objeto de minha pesquisa de mestrado (MEDEIROS, 1997); porém, neste trabalho, interessa compreender uma outra parte deste universo, ou seja, os agricultores familiares e suas relações sociais, de produção, o nível tecnológico, os agentes financiadores, suas representações e a atuação de associações, sindicatos e outras entidades, bem como a questão da assistência técnica, da comercialização e de seus planos futuros relacionados ao trabalho e à família.

Assim, após a descrição do processo histórico de ocupação da região e da produção agropecuária da Microrregião Geográfica de Presidente Prudente, apresento uma análise sobre a mobilidade populacional, a estrutura fundiária, as características dos estabelecimentos rurais dos municípios selecionados e dos produtores entrevistados.

Na Figura 1 (p. 15) destaca-se a localização da 10a Região Administrativa do Estado de São Paulo e também os municípios que compõem o EDR de Presidente Prudente.

Como já ressaltado na introdução deste estudo, será analisado, a seguir, a dinâmica do espaço rural, e, para melhor sistematizar o levantamento empírico, serão utilizados, como dados secundários, os dados agropecuários do Levantamento Censitário de Unidades de Produção Agrícola do Estado de São Paulo, 1997, realizado pela Secretaria de Agricultura e Abastecimento do Estado de São Paulo e dos Censos Agropecuários da FIBGE 1995/96.

Esclareço que, em 1997, a estrutura da rede da Secretaria de Agricultura e Abastecimento do Estado de São Paulo (SAA), no interior, foi alterada, (Decreto Estadual 41.559/97); desta maneira, os municípios foram então agrupados para comporem 40 regionais, conforme demonstrado na Figura 7. No Quadro 4, encontram-se os nomes dos municípios sedes correspondentes a cada regional.

Cada uma delas corresponde a um Escritório de Desenvolvimento Rural (EDR), da Coordenadoria de Assistência Técnica Integral (CATI). A Secretaria de Agricultura e Abastecimento do Estado de São Paulo (SAA) realizou, em 1995, o censo agropecuário conhecido como Projeto LUPA (Levantamento Censitário de Unidades de Produção Agrícola), com o intuito de auxiliar a atuação regional da SAA.

Ao entrar em contato com esses dados, pareceu-me que eles poderiam ser valiosos na análise proposta neste trabalho, pois são dados atualizados da atividade 


\section{FIGURA 7. REGIONAIS AGRÍCOLAS DO ESTADO DE SÃO PAULO}

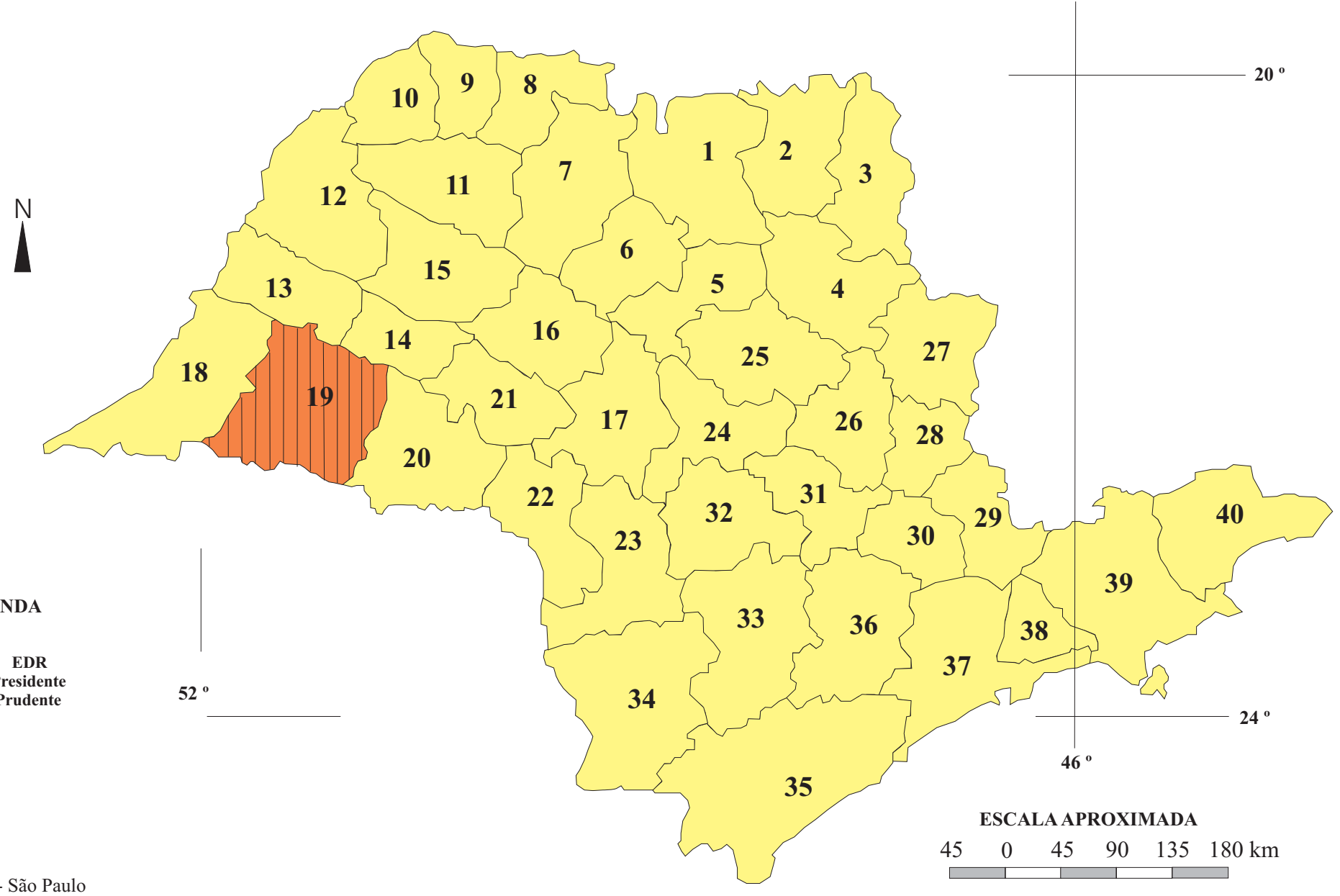


QUADRO 4. REGIONAIS AGRÍCOLAS DO ESTADO DE SÃO PAULO

\begin{tabular}{|c|l|l|l|}
\hline $\mathbf{N}^{\mathbf{0}}$ & EDR & $\mathrm{N}^{\mathrm{o}}$ & EDR \\
\hline 1 & BARRETOS & 21 & MARÍLIA \\
\hline 2 & ORLÂNDIA & 22 & OURINHOS \\
\hline 3 & FRANCA & 23 & AVARÉ \\
\hline 4 & RIBEIRÃO PRETO & 24 & JAÚ \\
\hline 5 & JABOTICABAL & 25 & ARARAQUARA \\
\hline 6 & CATANDUVA & 26 & LIMEIRA \\
\hline 7 & SÃO JOSÉ DO RIO PRETO & 27 & SÃO JOÃO DA BOA VISTA \\
\hline 8 & VOTUPORANGA & 28 & MOGI MIRIM \\
\hline 9 & FERNANDÓPOLIS & 29 & BRAGANÇA PAULISTA \\
\hline 10 & JALES & 30 & CAMPINAS \\
\hline 11 & GENERAL SALGADO & 31 & PIRACICABA \\
\hline 12 & ANDRADINA & 32 & BOTUCATU \\
\hline 13 & DRACENA & 33 & ITAPETININGA \\
\hline 14 & TUPÃ & 34 & ITAPEVA \\
\hline 15 & ARAÇATUBA & 35 & REGISTRO \\
\hline 16 & LINS & 36 & SOROCABA \\
\hline 17 & BAURU & 38 & MOGI DAS CRUZES \\
\hline 18 & PRESIDENTE VENCESLAU & 39 & PINDAMONHANGABA \\
\hline $\mathbf{1 9}$ & PRESIDENTE PRUDENTE & GUALO \\
\hline 20 & ASSIS & & \\
\hline
\end{tabular}

FONTE: CATI - São Paulo

ORGANIZAÇÃO: Célia Santos Medeiros, 2002. 
agropecuária paulista; portanto, são fontes de análises tanto da produção agrícola quanto das relações de produção, que podem, inclusive ser cruzados com dados da FIBGE.

O EDR de Presidente Prudente é constituído por 21 municípios, representados na Figura 8.

São eles: Alfredo Marcondes, Álvares Machado, Anhumas, Caiabu, Emilianópolis, Estrela do Norte, Iepê, Indiana, João Ramalho, Martinópolis, Nantes, Narandiba, Pirapozinho, Presidente Bernardes, Presidente Prudente, Rancharia, Regente Feijó, Sandovalina, Santo Expedito, Taciba e Tarabai.

Estes municípios têm uma área total de 963.000 ha e contam com uma população de 352.124 habitantes, sendo 37.684 destes residentes na área rural, segundo o censo do IBGE -1995/96. (Tabela 11)

Com relação à regionalização proposta pela FIBGE, a Microrregião Geográfica de Presidente Prudente, depois de passar por várias divisões, conta com 30 municípios, em uma área de $17.526 \mathrm{Km}^{2}$, correspondendo a 7,0\% do território paulista, e em 1996, concentrava uma população de 516.390 habitantes, ou seja, 1,5\% da população do Estado de São Paulo.

Estes municípios são polarizados pela cidade de Presidente Prudente, que detém a sede de 58\% de indústrias da região associadas à FIESP/CIESP, entre outros indicadores, fato que, segundo Sposito (1997. p.69), confirma esta polarização; entretanto, a produção agrícola local e regional tem mantido sua modesta participação no contexto da produção estadual, "levando-se em conta os principais produtos regionais em termos de área plantada e volumes de produção, para os três anos agrícolas analisados”. Ele destaca, ainda, a prioridade do uso do solo da região para a atividade pecuária.

Os demais municípios citados acima têm por base econômica a atividade pecuária e apresentam características econômicas e sociais bastante homogêneas, conforme pode-se verificar nas tabelas de população rural e a urbana, e nas relacionadas à estrutura fundiária.

No Anexo 2, como já citado anteriormente, comparecem as 10 (dez) principais culturas por estrato de área cultivada, por município do EDR de Presidente Prudente. 
1 - Emilianópolis

2 - Presidente Bernardes

3 - Sandovalina

4 - Pirapozinho

5 - Estrela do Norte

6 - Tarabai

7 - Álvares Machado

8 - Alfredo Marcondes

9 - Santo Expedito

10 - Presidente Prudente

11 - Anhumas

12 - Narandiba

13 - Taciba

14 - Regente Feijó

15 - Indiana

16 - Caiabu

17 - Martinópolis

18 - Nantes

19 - lepé

20 - Rancharia

21 - Joăo Ramalho

\section{Regional Agrícola de Presidente Prudente}

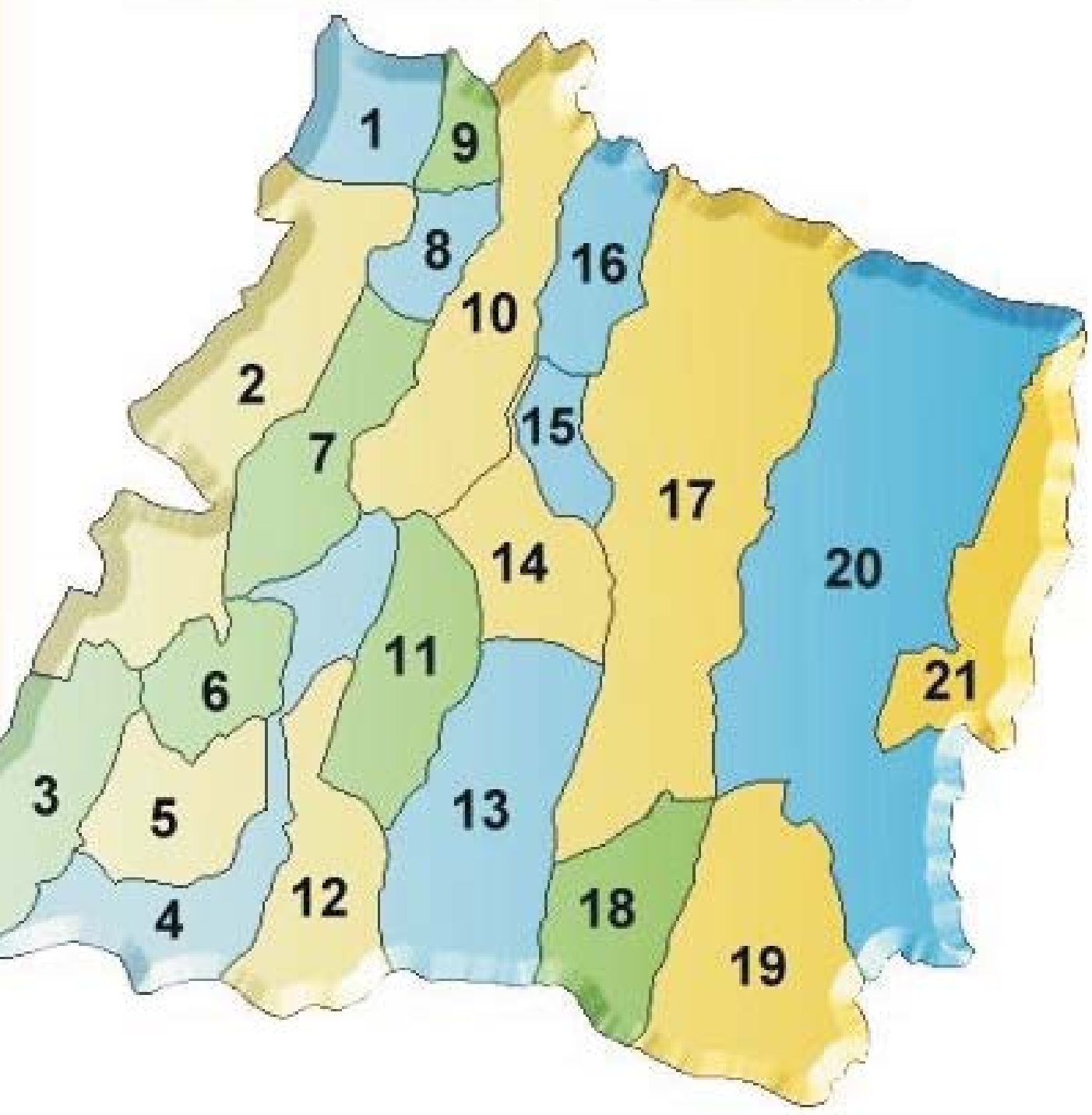




\subsection{MOBILIDADE POPULACIONAL - REGIÃO DE PRESIDENTE PRUDENTE}

Conforme abordado no capítulo 6.2, a expansão da atividade pecuária de corte extensiva provocou uma acentuação da concentração fundiária, através da incorporação de áreas, como as do Pontal do Paranapanema.

Juntamente com a crise econômica pela qual passaram as culturas que eram tradicionalmente cultivadas na região, como, por exemplo, o café, o algodão, o amendoim, entre outras, houve uma diminuição da renda dos agricultores familiares e uma diminuição da absorção de mão-de-obra, que provocou a expulsão de expressivo contingente populacional.

A mudança no perfil agropecuário e o fraco desempenho da economia regional, especialmente no que diz respeito ao setor industrial, fizeram com que a região não conseguisse reter parcela da população, passando a caracterizar-se como uma área de expulsão populacional. (HESPANHOl, 2000. p. 124)

Ressalta-se, contudo, que este fato também se deu em outras áreas do Oeste Paulista, como Araçatuba, Marília e São José do Rio Preto.

O esvaziamento populacional do extremo oeste do estado, para Leite (1981, p.129), ocorreu também pela atração exercida pela região metropolitana de São Paulo, que concentrava as principais atividades econômicas do país, ocasionando "uma recessão econômica que perdura há cerca de duas décadas [....] a população procura novas áreas em busca de trabalho.”

Entretanto, segundo Singer, para se entender a questão da mobilidade populacional, tão importante como a análise dos fatores de atração, é a análise dos fatores de expulsão da população de uma área. Desta maneira,

os fatores de expulsão que levam às migrações são de duas ordens: fatores de mudança, que decorrem da introdução de relações de produção capitalista nestas áreas, as quais acarretam a expropriação de camponeses, a expulsão de agregados, parceiros e de outros agricultores não proprietários, tendo por objetivo o aumento da produtividade do trabalho e a conseqüente redução do nível de emprego [...]; e fatores de estagnação, que se manifestam sob a forma de uma crescente pressão populacional sobre uma disponibilidade de áreas cultiváveis, que pode ser limitada tanto pela insuficiência física de terra aproveitável,como pela monopolização de grande parte da mesma, pelos grandes proprietários [....]. (SINGER, 1974, p. 33). 
Assim, percebe-se que os fatores de estagnação e de mudança se encaixam muito bem na realidade desta região, onde, expropriados dos meios de produção e de trabalho, pequenos produtores, inclusive arrendatários, parceiros, meeiros, etc. e trabalhadores rurais, foram obrigados a se deslocar, ora para a periferia de cidades maiores da região, ora para regiões com maior dinamismo econômico, fossem elas no próprio estado de São Paulo, ou mesmo em outras regiões do Brasil.

Desta maneira, a região de Presidente Prudente apresenta, desde a década de 1960, uma grande evasão populacional, que se acentuou nas décadas de 1970 e 1980, conforme se observa na Tabela 11.

Se, na década de 1950, predominava na região a população rural (76,3\%), em 1996, ela é, segundo dados da FIBGE, principalmente urbana ${ }^{78}$, com 85,3\% do total.

O esvaziamento do campo, pelos motivos expostos acima, provocou, então, um aumento da população urbana da região, principalmente na cidade de Presidente Prudente, fortalecida como centro regional pelos serviços e pela infra-estrutura oferecidos; entretanto, as ofertas de trabalho são insuficientes, tanto na área urbana quanto na rural, sendo que, quando elas existem, são de caráter informal e requerem pouca qualificação. 78 Essa afirmação é aceita aqui com restrições, pois discordo de algumas metodologias e critérios adotados pela
FIBGE, com relação ao termo “urbana”. 
TABELA 11. POPULAÇÃO URBANA E RURAL DA MRG DE PRESIDENTE PRUDENTE E ESTADO DE SÃO PAULO - 1950 - 1996

MRG - PRESIDENTE PRUDENTE

\begin{tabular}{|l|c|c|c|c|c|}
\hline Ano & $\begin{array}{l}\text { População } \\
\text { Urbana }\end{array}$ & $\%$ & $\begin{array}{l}\text { População } \\
\text { Rural }\end{array}$ & $\%$ & $\begin{array}{l}\text { População } \\
\text { Total }\end{array}$ \\
\hline 1950 & 82.969 & 23,7 & 266.786 & 76,3 & 349.755 \\
\hline 1960 & 156.295 & 40,0 & 234.357 & 60,0 & 390.652 \\
\hline 1970 & 233.423 & 53,8 & 199.663 & 46,2 & 433.086 \\
\hline 1980 & 320.172 & 74,5 & 109.321 & 25,5 & 429.493 \\
\hline 1991 & 416.918 & 83,6 & 81.972 & 16,4 & 498.890 \\
\hline 1996 & 448.290 & 85,3 & 77.482 & 14,7 & 525.772 \\
\hline
\end{tabular}

ESTADO DE SÃO PAULO

\begin{tabular}{|l|l|l|l|l|l|}
\hline Ano & $\begin{array}{l}\text { População } \\
\text { Urbana }\end{array}$ & $\%$ & $\begin{array}{l}\text { População } \\
\text { Rural }\end{array}$ & $\begin{array}{l}\text { População } \\
\text { Total }\end{array}$ \\
\hline 1950 & 4.904 .711 & 54,0 & 4.330 .212 & 46,0 & 9.134 .429 \\
\hline 1960 & 8.149 .979 & 62,8 & 4.824 .720 & 37,2 & 12.974 .699 \\
\hline 1970 & 14.436 .244 & 80,3 & 3.526 .449 & 19,7 & 17.958 .693 \\
\hline 1980 & 22.195 .330 & 88,6 & 2.845 .368 & 11,3 & 25.375 .199 \\
\hline 1991 & 29.314 .861 & 92,8 & 2.274 .064 & 7,2 & 31.588 .925 \\
\hline 1996 & 31.769 .219 & 93,1 & 2.351 .667 & 6,9 & 34.120 .886 \\
\hline
\end{tabular}

Fonte: F.I.B.G. E. Censos Demográficos de 1950, 1960, 1970, 1975, 1980, 1991 e Contagem Nacional da População de 1996.

Por outro lado, enquanto Presidente Prudente crescia em população, na década de 1970, outras cidades dos municípios da região viram-se em dificuldades, causadas pelo empobrecimento e pela saída da população, porque a economia, baseada na agricultura, se estagnava.

As administrações municipais enfrentaram limites para se estruturarem, o que dificultava ainda mais as condições para a permanência dessa população. 
Devido a esta situação econômica e social, o governo do Estado de São Paulo implanta programas de desenvolvimento regional ${ }^{79}$, no final da década de 1970; entretanto, eles não contribuíram muito, pois a manutenção da estrutura fundiária concentrada aprofundou a questão social na região.

Assim, conforme observou Hespanhol (2000. p.127),

[...] com o aprofundamento da crise econômica que atingiu a esfera federal e estadual no decorrer dos anos 1980, houve a diminuição no ritmo das obras públicas que, associada à expansão da cultura da cana-de-açúcar nas grandes propriedades, agravaram os conflitos sociais pela terra, especialmente no Pontal do Paranapanema ${ }^{80}$.

Esses conflitos, contudo, impulsionam a criação de assentamentos e reassentamentos rurais ${ }^{81}$, que retomam, no âmbito político, econômico, social e acadêmico, a questão da importância da luta pela terra, da produção agrícola familiar e seu fortalecimento, incluindo nela os agricultores familiares, arrendatários, parceiros, etc., que ainda permanecem no campo, bem como aqueles que têm lutado pela dignidade e pelo direito de serem sujeitos de sua história.

Desta forma, ao se comparar a média de crescimento populacional do Estado de São Paulo, a 10 ${ }^{\text {a }}$ Região Administrativa continua apresentando um baixo crescimento.

Entre 1990 e 1996, a população cresceu, em média, 0,66\% ao ano, contra a taxa média de 1,71\% ao ano do Estado de São Paulo, embora, como já vimos, essa tendência se verificasse desde a década de 1970, com a queda sistemática da participação relativa da sua

\footnotetext{
79 O Programa de Desenvolvimento do Pontal do Paranapanema, que foi lançado em 1978, pelo governador Paulo Egydio Martins, consistia no aproveitamento do potencial hidrelétrico dos rios Paraná e Paranapanema, com a construção de usinas, bem como dinamizar a área com a criação de 30 mil empregos diretos.(HESPANHOL, 2000, p. 128). Outro programa foi o PROOESTE - Programa de Desenvolvimento do Oeste Paulista, de 1979, que beneficiou também outras regiões. Visava aproveitar a infra-estrutura, inversão do fluxo migratório, o fortalecimento das economias regionais e a inserção do setor agropecuário paulista na pauta de exportações. Dele faziam parte, entre outros, o Programa de Expansão da Canavicultura para a Produção de Combustível do Estado de São Paulo - PROCANA -, Programa de Feijão Irrigado - PROFEIJÃO -, Programa de Aproveitamento de Várzeas Irrigadas - PROVÁRZEA.

80 As obras de construção das usinas de Porto Primavera, (atual UHE Sérgio Motta), Rosana eTaquaruçu, foram iniciadas em 1980.

${ }^{81}$ Sobre questões de luta pela terra e implantação de assentamentos e reassentamentos: LEITE, 1981; KALIL, 1984; ANTONIO, 1990; SILVEIRA, 1990; FERNANDES, 1994; SOUZA, 1996 e MENDES, 1998, entre outros.
} 
população no total da população do Estado, ou seja, de 3,85\% em 1970, para 2,65\% em 1980; de 2,36\% em 1990, atingindo 2,2\% em 1996.

E, através dos dados das Tabelas 12 e 13, para os anos de 1980 e de 1996, pode-se comparar a relação entre a população rural e a urbana, destacando os municípios que compõem atualmente o EDR, confirmando a migração populacional já demonstrada.

TABELA 12. POPULAÇÃO URBANA E RURAL-1980

\begin{tabular}{|c|c|c|c|c|}
\hline MUNICÍPIOS & $\begin{array}{l}\text { POPULAÇÃO } \\
\text { TOTAL }\end{array}$ & $\begin{array}{c}\text { POPULAÇÃO } \\
\text { URBANA }\end{array}$ & $\begin{array}{l}\text { POPULAÇÃO } \\
\text { RURAL }\end{array}$ & $\begin{array}{c}\text { PORCENTAGEM } \\
\text { POPULAÇÃO RURAL }\end{array}$ \\
\hline TOTAL DA REGIÃO & 293.452 & 228.817 & 64.635 & $22 \%$ \\
\hline Alfredo Marcondes & 4.313 & 2.103 & 2.210 & $51 \%$ \\
\hline Álvares Machado & 14.789 & 9.020 & 5.769 & $39 \%$ \\
\hline Anhumas & 3.418 & 1.438 & 1.980 & $53 \%$ \\
\hline Caiabu & 3.718 & 1.184 & 2.534 & $68 \%$ \\
\hline Estrela do Norte & 3.395 & 1.070 & 2.325 & $69 \%$ \\
\hline Iepê & 9.497 & 6.097 & 3.400 & $36 \%$ \\
\hline Indiana & 4.385 & 2.893 & 1.492 & $34 \%$ \\
\hline João Ramalho & 2.884 & 852 & 2.032 & $70 \%$ \\
\hline Martinópolis & 19.967 & 12.845 & 7.122 & $36 \%$ \\
\hline Narandiba & 3.538 & 1.518 & 2.020 & $57 \%$ \\
\hline Pirapozinho & 18.065 & 14.437 & 3.628 & $20 \%$ \\
\hline Presidente Bernardes & 15.867 & 8.428 & 7.439 & $47 \%$ \\
\hline Presidente Prudente & 141.129 & 133.510 & 7.619 & $5 \%$ \\
\hline Rancharia & 23.883 & 18.413 & 5.470 & $23 \%$ \\
\hline Regente Feijó & 11.187 & 8.128 & 3.059 & $27 \%$ \\
\hline Sandovalina & 3.023 & 1.129 & 1.894 & $62 \%$ \\
\hline Santo Expedito & 2.259 & 1.277 & 982 & $43 \%$ \\
\hline Taciba & 4.548 & 2.302 & 2.246 & $50 \%$ \\
\hline Tarabai & 3.587 & 2.173 & 1.414 & $40 \%$ \\
\hline
\end{tabular}

Fonte: Censo IBGE- 1980 * não haviam sido criados os municípios de Emilianópolis e de Nantes.

Dos 21 municípios pesquisados observa-se que, em 1980, muitos deles tinham mais de $50 \%$ da população no campo, como os municípios de João Ramalho, com 70\%, Estrela do Norte, com 69\%, Caiabu, com 68\%, Sandovalina, com 62\%, Narandiba, com 57\%, Anhumas, com 53\%, Alfredo Marcondes, com 51\% e Taciba, com 50\%.

Entretanto, conforme o gráfico 1 e a tabela 13, em 1996, nota-se a grande evasão populacional do campo para as cidades. A população rural representava $11 \%$ da população total, e a urbana, 89\% dos municípios estudados. 
GRÁFICO 1 
Por outro lado, alguns municípios apresentaram uma queda menor, devido a áreas com assentamentos rurais, implantados de 1984 a 2000.

TABELA 13. POPULAÇÃO URBANA E RURAL - 1996

\begin{tabular}{|c|c|c|c|c|}
\hline MUNICÍPIOS & $\begin{array}{l}\text { POPULAÇÃO } \\
\text { TOTAL }\end{array}$ & $\begin{array}{l}\text { POPULAÇÃO } \\
\text { URBANA }\end{array}$ & $\begin{array}{l}\text { POPULAÇÃO } \\
\text { RURAL }\end{array}$ & $\begin{array}{c}\text { PORCENTAGEM } \\
\text { POPULAÇÃO RURAL }\end{array}$ \\
\hline & 352.124 & 314.440 & 37.684 & $11 \%$ \\
\hline Alfredo Marcondes & 3.630 & 2.594 & 1.036 & $29 \%$ \\
\hline Álvares Machado & 21.431 & 18.707 & 2.724 & $13 \%$ \\
\hline Anhumas & 3.136 & 2.212 & 924 & $29 \%$ \\
\hline Caiabu & 3.709 & 2.594 & 1.115 & $30 \%$ \\
\hline Emilianópolis & 2.777 & 1.940 & 837 & $30 \%$ \\
\hline Estrela do Norte & 2.786 & 1.872 & 914 & $33 \%$ \\
\hline Iepê & 9.382 & 7.533 & 1.849 & $20 \%$ \\
\hline Indiana & 4.733 & 3.874 & 859 & $18 \%$ \\
\hline João Ramalho & 3.619 & 2,748 & 871 & $24 \%$ \\
\hline Martinópolis & 21.361 & 17.352 & 4.009 & $19 \%$ \\
\hline Nantes* & - & - & - & - \\
\hline Narandiba & 3.784 & 2.104 & 1.680 & $44 \%$ \\
\hline Pirapozinho & 21.963 & 19.469 & 2.494 & $11 \%$ \\
\hline Presidente Bernardes & 12.210 & 8.169 & 4.041 & $33 \%$ \\
\hline Presidente Prudente & 177.367 & 173.339 & 4.028 & $2 \%$ \\
\hline Rancharia & 28.282 & 24.174 & 4.108 & $15 \%$ \\
\hline Regente Feijó & 16.276 & 13.521 & 2.755 & $17 \%$ \\
\hline Sandovalina & 2.680 & 1.543 & 1.137 & $42 \%$ \\
\hline Santo Expedito & 2.312 & 1.691 & 621 & $27 \%$ \\
\hline Taciba & 5.051 & 3.970 & 1.081 & $21 \%$ \\
\hline Tarabai & 5.635 & 5.034 & 601 & $11 \%$ \\
\hline
\end{tabular}

Fonte: Censo Populacional - IBGE-1996.

* não há dados para o município de Nantes.

Conforme Fernandes e Ramalho (2001, p.248), no município de Martinópolis há 2 assentamentos, com 124 famílias, em 2.364 ha.

O município de Presidente Bernardes conta com 8 assentamentos, com 266 famílias, ocupando uma área de 7.189 há; no de Rancharia há 1 assentamento, com 124 
famílias, em 2.493 ha e o de Sandovalina, também com 1 assentamento, com 130 famílias, que ocupam uma área de 2.628 ha ${ }^{82}$.

Não obstante, com relação à população total, pode-se afirmar que essa queda se explica também devido à atuação fraca dos sujeitos sociais pela criação de oportunidades de negócios e de emprego no ritmo e quantidade adequados para absorver e fixar sua população urbana; e, quanto à população rural, por uma organização deficiente por parte destes grupos e de ações e políticas voltadas para o setor que efetivamente provocassem avanços sociais e econômicos .

Conforme o relatório PRODER/SEBRAE (1999, p.9),

[...] as regiões situadas no Oeste Paulista que apresentam baixo grau de dinamismo em virtude de continuarem estritamente vinculadas e dependentes da agricultura com baixo grau de integração agroindustrial têm apresentado baixas taxas de crescimento populacional, não conseguindo gerar empregos e condições de sobrevivência nem mesmo para a população originária da região, que, em conseqüência, desloca-se para as zonas que oferecem maiores possibilidades de inserção no mercado de trabalho.

Outro aspecto a ser destacado é a tendência de envelhecimento de sua estrutura populacional, pois os dados do Censo Populacional do IBGE revelam um movimento migratório de mão-de-obra entre a população com idade até de 24 anos, fato que pôde ser constatado na pesquisa de campo, com relação também à população rural. 82 Embora nesta pesquisa não fosse possível aprofundar as análises sobre os assentamentos rurais, pode-se inferir
que eles têm fortalecido a produção familiar na área pesquisada. 


\subsection{RELAÇÕES DE PRODUÇÃO NA AGRICULTURA NA MRG DE PRESIDENTE PRUDENTE}

Acredito que o acesso ou a permanência na terra seja condição básica para que os produtores familiares possam continuar na atividade agropecuária, pois é através dela que o produtor rural pode se diferenciar de um trabalhador assalariado, é também a garantia de que será possível dar segurança para si e sua família.

A tabela 14 apresenta a condição do produtor na MRG de Presidente Prudente, na qual utilizei dados da FIBGE, pois é possível analisar-se um período mais longo. Entretanto, a tabela 14.2 traz informações sobre a condição do produtor somente para os 21 municípios do EDR.

Verifica-se que, em 1980, os proprietários representavam 60,0\% dos estabelecimentos e 92,5\% da área total ocupada; os arrendatários, por outro lado, detinham 22,1\% dos estabelecimentos em apenas 4,9\% da área. A categoria de parceiros e ocupantes estava representada em $6,7 \%$ e $10,6 \%$ dos estabelecimentos respectivamente e, com relação à área, em $0,9 \%$ e $1,7 \%$.

Em 1995/96, os proprietários concentravam 82,2\% dos estabelecimentos e detinham 93,3\% da área. Os arrendatários, por sua vez, representavam 7,4\% da condição de produtor no número de estabelecimentos e ocupavam 3,9\% da área, os parceiros e ocupantes representavam respectivamente, $1,0 \%$ e 9,4\% dos estabelecimentos em uma área de 1,6\% e $1,2 \%$ do total.

Constata-se, através dos dados, o aumento do número de produtores na condição de proprietários e a redução na área ocupada por eles, o que pode revelar uma maior concentração. Já o produtor rural na condição de arrendatário apresentou uma grande redução no levantamento de 1995/96, situação que já foi ressaltada nesse trabalho e será analisada também no capítulo 8. 
TABELA 14. CONDIÇÃO DO PRODUTOR NA MRG DE PRESIDENTE PRUDENTE, 1980 - 1995/1996

Número de Estabelecimentos

\begin{tabular}{c|c|c|c|c|c|c|c|c|c|c|c|c}
\hline \multirow{2}{*}{ Anos } & \multicolumn{2}{|c|}{ Proprietário } & \multicolumn{2}{c|}{ Arrendatário } & \multicolumn{2}{c|}{ Parceiro } & \multicolumn{2}{c|}{ Ocupante } & \multicolumn{2}{c|}{ Outros } & \multicolumn{2}{c}{ Total } \\
\cline { 2 - 14 } & $\mathrm{N}^{\mathrm{o}}$ & $\%$ & $\mathrm{~N}^{\mathrm{o}}$ & $\%$ & $\mathrm{~N}^{\mathrm{o}}$ & $\%$ & $\mathrm{~N}^{\mathrm{o}}$ & $\%$ & $\mathrm{~N}^{\mathrm{o}}$ & $\%$ & $\mathrm{~N}^{\mathrm{o}}$ & $\%$ \\
\hline 1980 & 8.307 & 60,6 & 3.048 & 22,1 & 929 & 6,7 & 1.469 & 10,6 & 83 & 0,6 & 13.863 & 100,0 \\
\hline 1985 & 9.497 & 60,7 & 3.519 & 22,6 & 644 & 4,1 & 1.978 & 12,6 & - & - & 15.638 & 100,0 \\
\hline $1995 / 1996$ & 11.182 & 82,2 & 1.005 & 7,4 & 135 & 1,0 & 1.278 & 9,4 & - & - & 13.600 & 100,0 \\
\hline
\end{tabular}

Fonte: F. I. B. G. E. - Censos Agropecuários do Estado de São Paulo de 1980,1985 e 1995/1996.

Área (em ha.)

\begin{tabular}{c|c|c|c|c|c|c|c|c|c|c|c|c}
\hline \multirow{2}{*}{ Anos } & \multicolumn{2}{|c|}{ Proprietário } & \multicolumn{2}{c|}{ Arrendatário } & \multicolumn{2}{c|}{ Parceiro } & \multicolumn{2}{c|}{ Ocupante } & \multicolumn{2}{c|}{ Outros } & \multicolumn{2}{c}{ Total } \\
\cline { 2 - 30 } & em ha & $\%$ & em ha & $\%$ & em ha & $\%$ & em ha & $\%$ & em ha & $\%$ & em ha & $\%$ \\
\hline 1980 & 1.572 .766 & 92,5 & 84.359 & 4,9 & 14.621 & 0,9 & 28.047 & 1,7 & & & 1.699 .964 & 100,0 \\
\hline 1985 & 1.509 .128 & 89,9 & 124.129 & 7,4 & 11.253 & 0,7 & 34.251 & 2,0 & - & - & 100,0 \\
\hline $1995 / 1996$ & 1.399 .514 & 93,3 & 54.447 & 3,9 & 23.826 & 1,6 & 17.884 & 1,2 & - & - & 100,0 \\
\hline
\end{tabular}

Fonte: F. I. B. G. E. - Censos Agropecuários do Estado de São Paulo de 1980,1985 e 1995/1996. 
TABELA 14.1. PESSOAL OCUPADO NOS ESTABELECIMENTOS AGROPECUÁRIOS DO ESTADO DE SÃO PAULO E DA MRG DE PRESIDENTE PRUDENTE, 1980 - 1995/96

\begin{tabular}{|c|c|c|c|c|c|c|c|c|c|c|c|c|c|}
\hline \multirow[b]{2}{*}{ Anos } & \multirow[b]{2}{*}{ Regiões } & \multicolumn{2}{|c|}{$\begin{array}{c}\text { Responsáveis } \\
\text { e Membros } \\
\text { não- } \\
\text { remunerados }\end{array}$} & \multicolumn{2}{|c|}{$\begin{array}{l}\text { Empregados } \\
\text { Permanentes }\end{array}$} & \multicolumn{2}{|c|}{$\begin{array}{l}\text { Empregados } \\
\text { Temporários }\end{array}$} & \multicolumn{2}{|c|}{ Parceiros } & \multicolumn{2}{|c|}{$\begin{array}{c}\text { Outra } \\
\text { Condição }\end{array}$} & \multicolumn{2}{|c|}{ Total } \\
\hline & & $\mathrm{N}^{0}$ & $\%$ & $\mathrm{~N}^{0}$ & $\%$ & $\mathrm{~N}^{0}$ & $\%$ & $\mathrm{~N}^{0}$ & $\%$ & $\mathrm{~N}^{0}$ & $\%$ & $\mathrm{~N}^{0}$ & $\%$ \\
\hline \multirow[t]{2}{*}{1980} & SP & 662.401 & 48,1 & 386.103 & 28,0 & 278.264 & 20,2 & 44.299 & 3,3 & 5.396 & 0,4 & 1.376 .463 & 100,0 \\
\hline & MRGPP & 38.894 & 57,9 & 10.695 & 15,9 & 17.244 & 25,6 & 179 & 0,3 & 203 & 0,3 & 67.215 & 100,0 \\
\hline \multirow[t]{2}{*}{1985} & SP & 653.781 & 48,2 & 410.466 & 30,3 & 240.433 & 17,7 & 36.080 & 2,6 & 16.353 & 1,2 & 1.357 .113 & 100,0 \\
\hline & MRGPP & 39.024 & 55,7 & 11.929 & 17,1 & 18.717 & 26,8 & 215 & 0,3 & 90 & 0,1 & 69.975 & 100,0 \\
\hline \multirow[t]{2}{*}{ 1995/1996 } & 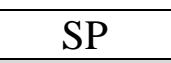 & 438.660 & 47,9 & 343.863 & 37,6 & 71.824 & 7,8 & 26.489 & 2,9 & 34.118 & 3,8 & 914.954 & 100,0 \\
\hline & MRGPP & 29.862 & 65,1 & 10.137 & 22,2 & 4.319 & 9,4 & 210 & 0,4 & 1.363 & 2,9 & 45.891 & 100,0 \\
\hline
\end{tabular}

Fonte: F. I. B. G. E. - Censos Agropecuários do Estado de São Paulo de 1980,1985 e 1995/1996. 
TABELA 14.2. CONDIÇÃO DO PRODUTOR POR MUNICÍPIO DO EDR DE PRESIDENTE PRUDENTE - $1995 / 96$

\begin{tabular}{|c|c|c|c|c|c|c|c|c|c|c|c|c|c|c|c|c|c|c|c|c|}
\hline & \multicolumn{4}{|c|}{ PROPRIETÁRIO } & \multicolumn{4}{|c|}{ ARRENDATÁRIO } & \multicolumn{4}{|c|}{ PARCEIRO } & \multicolumn{4}{|c|}{ OCUPANTE } & \multicolumn{4}{|c|}{ TOTAL } \\
\hline MUNICÍPIOS & $\mathbf{N}^{\mathbf{0}}$ & $\%$ & ÁREA ha & $\%$ & $\mathbf{N}^{\mathbf{0}}$ & $\%$ & ÁREA ha & $\%$ & $\mathrm{~N}^{\mathrm{O}}$ & $\%$ & ÁREA ha & $\%$ & $\mathbf{N}^{\mathbf{0}}$ & $\%$ & ÁREA ha & $\%$ & ÁREA ha & $\%$ & ÁREA ha & $\%$ \\
\hline Alfredo Marcondes & 260 & 4 & 10322 & 1 & 13 & 2 & 451 & 1 & 5 & 5 & 42 & 0 & 16 & 3 & 362 & 4 & 294 & 4 & 11.177 & 1 \\
\hline Álvares Machado & 653 & 9 & 27485 & 4 & 72 & 10 & 1327 & 3 & 3 & 3 & 15 & 0 & 14 & 3 & 102 & 1 & 742 & 9 & 28.929 & 4 \\
\hline Anhumas & 239 & 3 & 29782 & 4 & 16 & 2 & 1248 & 3 & \begin{tabular}{l|l}
0 \\
\end{tabular} & - & 0 & - & 3 & 1 & 125 & 1 & 258 & 3 & 31.155 & 4 \\
\hline Caiabu & 334 & 5 & 20535 & 3 & 45 & 6 & 476 & 1 & 38 & 39 & 191 & 2 & 25 & 5 & 192 & 2 & 442 & 5 & 21.394 & 3 \\
\hline Emilianópolis & 220 & 3 & 19520 & 3 & 36 & 5 & 770 & 2 & 0 & - & 0 & - & 9 & 2 & 102 & 1 & 265 & 3 & 20.392 & 2 \\
\hline Estrela do Norte & 174 & 3 & 27235 & 4 & 10 & 1 & 737 & 2 & 4 & 4 & 276 & 3 & 9 & 2 & 676 & 7 & 197 & 2 & 28.924 & 4 \\
\hline Iepê & 374 & 5 & 63749 & 8 & 53 & 7 & 4357 & 11 & 0 & 3 & 664 & 6 & 6 & 1 & 526 & 5 & 433 & 5 & 69.296 & 8 \\
\hline Indiana & 181 & 3 & 8602 & 1 & 21 & 3 & 938 & 2 & 3 & 3 & 501 & 5 & 2 & 0 & 2 & 0 & 207 & 3 & 10.043 & 1 \\
\hline João Ramalho & 208 & 3 & 33596 & 4 & 29 & 4 & 1578 & 4 & 6 & 6 & 1975 & 18 & 3 & 1 & 16 & 0 & 246 & 3 & 37.165 & 5 \\
\hline Martinópolis & 622 & 9 & 105104 & 14 & 71 & 10 & 6554 & 16 & 7 & 7 & 337 & 3 & 53 & 12 & 1175 & 12 & 753 & 9 & 113.170 & 14 \\
\hline Nantes & & & & & & & & & & & & & & & & & & & & \\
\hline Narandiba & 193 & 3 & 313 & 0 & 28 & 4 & 1769 & 4 & 10 & 1 & 4 & 0 & 27 & 6 & 128 & 1 & 249 & 3 & 2.214 & 0 \\
\hline Pirapozinho & 261 & 4 & 35920 & 5 & 22 & 3 & 1400 & 3 & \begin{tabular}{|l|}
2 \\
\end{tabular} & 2 & 15 & 0 & 15 & 3 & 495 & 5 & 300 & 4 & 37.830 & 5 \\
\hline Presidente Bernardes & 688 & 10 & 69067 & 9 & 71 & 10 & 5423 & 13 & 9 & 9 & 64 & 1 & 65 & 14 & 1826 & 19 & 833 & 10 & 76.380 & 9 \\
\hline Presidente Prudente & 785 & 11 & 39146 & 5 & 53 & 7 & 1414 & 3 & \begin{tabular}{|l|}
3 \\
\end{tabular} & 3 & 16 & 0 & 74 & 16 & 1157 & 12 & 915 & 11 & 41.733 & 5 \\
\hline Rancharia & 519 & 8 & 127016 & 17 & 64 & 9 & 6584 & 16 & 4 & 4 & 6384 & 59 & 106 & 23 & 1875 & 19 & 693 & 8 & 141.859 & 17 \\
\hline Regente Feijó & 364 & 5 & 24167 & 3 & 38 & 5 & 1199 & 3 & 4 & 4 & 24 & 0 & 0 & - & 0 & - & 406 & 5 & 25.390 & 3 \\
\hline Sandovalina & 92 & 1 & 39782 & 5 & 9 & 1 & 869 & 2 & 1 & 1 & 121 & 1 & 3 & 1 & 9 & 0 & 105 & 1 & 40.781 & 5 \\
\hline Santo Expedito & 118 & 2 & 9153 & 1 & 16 & 2 & 289 & 1 & \begin{tabular}{|l|}
2 \\
\end{tabular} & 2 & 36 & 0 & 0 & - & 0 & - & 136 & 2 & 9.478 & 1 \\
\hline Taciba & 297 & 4 & 48786 & 6 & 35 & 5 & 2493 & 6 & \begin{tabular}{|l|}
5 \\
\end{tabular} & 5 & 132 & 1 & 19 & 4 & 456 & 5 & 356 & 4 & 51.867 & 6 \\
\hline Tarabai & 135 & 2 & 16660 & 2 & 26 & 4 & 1153 & 3 & \begin{tabular}{|l|}
0 \\
\end{tabular} & - & 0 & - & 9 & 2 & 489 & 5 & 170 & 2 & 18.302 & 2 \\
\hline TOTAL & 6910 & 100 & 755940 & 100 & 728 & 100 & 41029 & 100 & 97 & 100 & 10797 & 100 & 458 & 100 & 9713 & 100 & 8.193 & 100 & 817.479 & 100 \\
\hline
\end{tabular}

Fonte: F.I.B.G.E. - Censos Agropecuários do Estado de São Paulo de 1995/96. 
De maneira geral, a redução observada com relação aos arrendatários, entre 1980 e 1995/96, se deve então, principalmente, ao declínio da cultura do algodão na região nas últimas décadas.

Entretanto verificam-se muitos tipos de arrendamento, inclusive de arrendatários capitalistas que não residem na área rural e que investem em agricultura. Esses arrendatários, com maiores recursos financeiros, podem utilizar sementes melhoradas, adubos, máquinas agrícolas, etc..

Enquanto os arrendatários com menores recursos, ao se utilizarem, basicamente, da força de trabalho da família, ao usar técnicas agrícolas muitas vezes precárias, têm enfrentado muitas dificuldades de acesso à terra, pois o proprietário que arrenda sua terra quer garantias, entre elas a de conservação, que aqueles não conseguem oferecer.

Na categoria dos parceiros, observou-se uma diminuição com relação ao número de estabelecimentos; contudo, houve um aumento da porcentagem em área ocupada por esses produtores, embora muito aquém da área ocupada em 1950, que somava 5,8\% do total.

Os ocupantes, por sua vez, passaram também por uma diminuição, tanto no número de estabelecimentos como em área. Pode-se inferir, ainda, que esta categoria pode ter se beneficiado dos assentamentos e reassentamentos implantados na região desde a década de 1980. 


\subsection{REPRESENTAÇÃO SOCIAL DOS PRODUTORES RURAIS}

A produção familiar é caracterizada por ser, no seu conjunto, um grande número de unidades produtivas que, freqüentemente, apresentam um nível de organização fraca. Para a maioria dos produtores, a terra e o dinheiro são fatores que podem limitar o desenvolvimento das unidades familiares.

Por outro lado, essas unidades podem se relacionar com mercados de insumos agropecuários, de processamento ou de distribuição da produção que são fortemente concentrados, além de que, na produção agrícola, por sua perecibilidade e sazonalidade, o produtor pode enfrentar problemas de comercialização.

Assim, as formas de representação social dos produtores são muito importantes, pois, através delas eles poderão ganhar, tanto no tamanho, nos processos de compra e venda da produção, quanto pela divisão, isto é, do uso comunitário, entre vários produtores, de máquinas, equipamentos, armazéns, etc..

As associações e cooperativas representam, para os produtores familiares, possibilidades de ganhos com melhores preços nas compras e nas vendas, seja em produtos, insumos ou máquinas e na obtenção de financiamentos governamentais. Podem também ter, através delas, a introdução de novas tecnologias e formas de agregar valor ao seu produto.

Desta forma, o Censo Agropecuário da FIBGE - 1995/96, registrou, no Estado de São Paulo, 65,9 mil filiações às cooperativas, correspondendo a 36,7\% do total dos estabelecimentos. Na MRG de Presidente Prudente, ela representou 34,4\% do total dos informantes.

Conforme o relatório PRODER/SEBRAE (1998), as cooperativas agropecuárias têm como principais produtos o leite, beneficiado pela COOLVAP (a maior cooperativa regional, que conta também com uma cooperativa de crédito); o café, comercializado por 6 cooperativas regionais; o algodão, comercializado por 2 cooperativas; e a batata-doce, o abacaxi, o maracujá, a manga e a goiaba.

Com relação às Associações, dados do Instituto de Cooperativismo e Associativismo - ICA, e a CATI (1998), o EDR de Presidente Prudente conta com 32 Associações, que representam 7,34\% do total estadual. 
Com relação ao número de associados, conta com 1252 produtores. A maioria das Associações foi implantada no fim da década de 1980 e na de 1990, ressaltandose a de Tarabai, com 122 associados, a de Alfredo Marcondes, com 100 associados, a de Estrela do Norte, com 118 e as de Álvares Machado, que conta com 12 associações, totalizando 233 filiados.

Apesar desses dados, a região ainda apresenta um nível incipiente de organização da produção. Existem também associações e cooperativas que estão ligadas aos assentamentos, contribuindo assim para mudar o perfil da organização regional deste grupo.

Não obstante a necessidade de haver um aumento de novas associações é necessário um cuidado com as que já existem, através de um treinamento gerencial adequado aos seus dirigentes, e que elas possam, depois, atingir status de cooperativas.

As cooperativas e as associações são organizações que não visam lucro. $\mathrm{O}$ processo de decisão ocorre por meio de uma assembléia geral e o monitoramento da eficácia da gestão é efetuado pelo conselho fiscal, composto por associados.

Essas organizações podem, então, possibilitar um aumento no nível de renda dos produtores familiares. Entretanto, conforme se pode observar na pesquisa de campo, há muita resistência dos produtores em se organizarem. 


\subsection{A ESTRUTURA FUNDIÁRIA}

Conforme já foi tratado no capítulo 6, é possível constatar-se que, desde o início da ocupação dessa região, a estrutura fundiária se apresentou muito concentrada, embora também sempre houvesse a presença de pequenas propriedades.

Com relação à estrutura fundiária, a Mesorregião de Presidente Prudente, que corresponde aos municípios da $10^{\mathrm{a}}$ Região Administrativa, segundo dados da FIBGE, apresenta uma concentração fundiária maior que a média do Estado de São Paulo.

Enquanto no conjunto das demais Mesorregiões do estado os estabelecimentos com menos de mil hectares cobrem 73,6\% da área destinada a atividades agropecuárias, na Mesorregião de Presidente Prudente, esse percentual é de 62,2\%; já na área agrícola do Estado, as propriedades com menos de mil hectares correspondem a 71,8\%.

A região em questão detém 12,1\% da área agrícola do Estado de São Paulo e 12,5\% da área das propriedades. A área de arrendamentos é de 7,1\%; a área de parcerias, de 10,7\%; e, as controladas por ocupantes, é de 13,3\%.

Observa-se, assim, um baixo nível de arrendamentos e de parcerias, e do número de ocupações, o que pode estar relacionado aos problemas de titulação das terras na região, assim como à falta de estímulo do produtor, frente às dificuldades com relação ao crédito rural (custeio e investimento) ${ }^{83}$, aos preços e à comercialização.

Pode-se afirmar que a questão fundiária induz ao aparecimento de um padrão de ocupação do solo pouco eficiente do ponto de vista social, deixando de dar oportunidades de reprodução a um grande número de pessoas; e, do tecnológico, provocado pela insegurança do retorno de investimentos, nota-se a ocorrência de mais áreas de lavouras temporárias e de pecuária extensiva, e menos de culturas permanentes.

Desta forma, o volume de investimentos fixos pode ficar aquém do ótimo, assim como a incerteza quanto ao controle das terras pode diminuir investimentos de longo prazo.

${ }^{83}$ Cf. Pereira, 2000. 
As tabelas 15 e 16 mostram a estrutura fundiária da região; a primeira em 1985, segundo dados do Censo Agropecuário do IBGE; e, a segunda, com dados do projeto LUPA, ligado à SAA, levantados no ano agrícola de 1995/96.

Esses dados têm algumas diferenças de metodologia e de conceitos que merecem esclarecimentos. Assim, Estabelecimento rural é um critério usado pelo IBGE para cálculo de área cultivada; e, UPA é a unidade de produção agropecuária, critério usado pela Secretaria de Abastecimento e Agricultura do Estado de São Paulo, no Projeto LUPA.

Encontram-se, ainda, nos documentos analisados para essa pesquisa, os termos Propriedade rural, significando área contínua registrada em cartório (unidade de propriedade); e, ainda, Imóvel Rural, como sendo o conjunto de propriedades contíguas do(s) mesmo(s) proprietário(s), conceito utilizado pelo Ministério da Agricultura e do Abastecimento (MAA) e pelo INCRA; e, Estabelecimento agropecuário, estabelecimento este subordinado a um único produtor, onde se processa a exploração agropecuária.

Adotei tais termos na análise dos dados, cada um segundo sua fonte. Utilizei também, por vezes, o termo agricultor ou produtor rural para determinar o responsável (proprietário ou não) por um ou mais estabelecimento(s) rural (ais).

Serão analisados os dados das tabelas abaixo, observando-se, entretanto, essas diferenças.

Na tabela 15, estão os dados que comparam a estrutura fundiária da Delegacia Agrícola de Presidente Prudente, que contava, naquele período, com 12 municípios; os da Alta Sorocabana, somando 30 municípios, e os do Estado de São Paulo.

Com relação aos municípios da Alta Sorocabana, constata-se que os estabelecimentos com área de até 100 hectares representavam 20\% do total, enquanto aqueles, com área de 100 a mais de 1000 hectares, representavam 80\% do total; e, o número dos estabelecimentos, por sua vez, representava, respectivamente, $85 \%$ e $15 \%$, o que demonstra a grande concentração fundiária nesta região. 
TABELA 15. ESTRUTURA FUNDIÁRIA - 1985

\begin{tabular}{|l|r|r|r|r|r|r|}
\hline & \multicolumn{2}{|c|}{ DAPP ${ }^{*} 1$} & \multicolumn{2}{c|}{ Alta Sorocabana*2 } & \multicolumn{2}{c|}{ Estado de São Paulo } \\
\cline { 2 - 8 } & $\begin{array}{l}\text { Número de } \\
\text { Estabeleci- } \\
\text { mentos }\end{array}$ & \multicolumn{1}{|c|}{$\begin{array}{l}\text { Área } \\
\text { (ha) }\end{array}$} & $\begin{array}{l}\text { Número de } \\
\text { Estabeleci- } \\
\text { mentos }\end{array}$ & $\begin{array}{c}\text { Área } \\
\text { (ha) }\end{array}$ & $\begin{array}{l}\text { Número de } \\
\text { Estabeleci- } \\
\text { mentos }\end{array}$ & $\begin{array}{c}\text { Área } \\
\text { (ha) }\end{array}$ \\
\hline Menos de 1 ha & 30 & 14 & 75 & 27 & 8.480 & 4.130 \\
\hline 1 a menos de 10 ha & 1.409 & 8.553 & 3.549 & 20.673 & 91.718 & 479.527 \\
\hline 10 a menos de 100 ha & 3.094 & 99.589 & 7.405 & 244.627 & 143.763 & 4.878 .042 \\
\hline 100 a menos de 500 ha & 468 & 88.170 & 1.501 & 308.954 & 31.329 & 6.494 .546 \\
\hline 500 a menos de 1000 ha & 78 & 55.102 & 257 & 181.038 & 3.978 & 2.759 .009 \\
\hline 1000 a mais ha & 50 & 117.403 & 244 & 535.972 & 2.590 & 5.630 .029 \\
\hline TOTAL & 5.129 & 368.831 & 13.031 & 1.291 .291 & 281.858 & 20.245 .283 \\
\hline
\end{tabular}

FONTE: Censo Agropecuário FIBGE, n. ํ 21, 1985.

*1- DELEGACIA AGRÍCOLA DE PRESIDENTE PRUDENTE (12 municípios)

*2 - ALTA SOROCABANA (30 municípios)

Nos dados da tabela 16, relativos a 21 municípios do Escritório de Desenvolvimento Rural de Presidente Prudente, coletados no ano agrícola de 1995/96, tem-se o número de propriedades por estrato de área, o que mostra a forte presença das unidades com área até 100 hectares, conforme já foi comentado em capítulo anterior.

Isso revela que as mesmas têm resistido, e, mesmo em alguns municípios, têm aumentado ${ }^{84}$, conseguindo manter sua reprodução social e econômica, apesar das dificuldades encontradas, como aquelas relatadas nos depoimentos dos produtores entrevistados, que serão tratados no próximo capítulo.

Reconheço, porém, que essas propriedades não se caracterizam por serem, na sua totalidade, baseadas na produção familiar; faltam-me, ainda, dados mais concretos; contudo, pode-se afirmar que ela é bastante significativa.

84 No Pontal do Paranapanema, houve um aumento no período 1984-2000, em 79 assentamentos, que representam 4597 famílias. Cf. Fernandes, 2001. 
TABELA 16. EDR DE PRESIDENTE PRUDENTE - NÚMERO DE PROPRIEDADES POR ESTRATO DE ÁREA, 1995/96

\begin{tabular}{|c|c|c|c|c|c|c|c|}
\hline MUNICIPIOS & 0-10 ha & 11-50 ha & 51-100 ha & 101-500 ha & 501-1.000ha & $>1.000$ ha & TOTAL \\
\hline Alfredo Marcondes & 136 & 292 & 41 & 13 & 2 & - & 484 \\
\hline Álvares Machado & 220 & 555 & 82 & 60 & 3 & - & 920 \\
\hline Anhumas & 15 & 157 & 50 & 50 & 6 & - & 283 \\
\hline Caiabu & 105 & 195 & 36 & 31 & 3 & 5 & 375 \\
\hline Emilianópolis & 24 & 133 & 50 & 47 & 6 & 2 & 262 \\
\hline Estrela do Norte & 3 & 148 & 9 & 26 & 9 & 6 & 201 \\
\hline Iepê & 84 & 190 & 71 & 87 & 30 & 14 & 476 \\
\hline Indiana & 66 & 146 & 28 & 24 & 2 & - & 266 \\
\hline João Ramalho & 34 & 116 & 32 & 57 & 9 & 2 & 250 \\
\hline Martinópolis & 154 & 286 & 112 & 146 & 24 & 22 & 744 \\
\hline Nantes* & - & - & - & - & - & - & - \\
\hline Narandiba & 13 & 57 & 21 & 20 & 5 & 6 & 122 \\
\hline Pirapozinho & 82 & 149 & 39 & 40 & 15 & 9 & 334 \\
\hline Presidente Bernardes & 120 & 413 & 84 & 106 & 12 & 11 & 746 \\
\hline \begin{tabular}{|l} 
Presidente Prudente \\
\end{tabular} & 320 & 605 & 119 & 68 & 3 & 5 & 1120 \\
\hline Rancharia & 58 & 260 & 137 & 197 & 30 & 27 & 709 \\
\hline Regente Feijó & 93 & 203 & 58 & 46 & 3 & 2 & 405 \\
\hline Sandovalina & 5 & 23 & 10 & 49 & 12 & 12 & 111 \\
\hline SantoExpedito & 28 & 100 & 222 & 12 & 3 & 1 & 166 \\
\hline Taciba & 34 & 137 & 67 & 55 & 16 & 9 & 318 \\
\hline \begin{tabular}{|l|} 
Tarabai \\
\end{tabular} & 33 & 108 & 29 & 26 & 7 & 3 & 206 \\
\hline TOTAL & 1627 & 4273 & 1097 & 1160 & 200 & 141 & 8498 \\
\hline
\end{tabular}

Fonte: Projeto LUPA/1997

* o município de Nantes não era emancipado à época do levantamento.

As áreas com até 100 hectares representam, assim, 82,34\% do total do EDR. Em alguns municípios, elas chegam a representar mais de 90\%, como Alfredo Marcondes, com 96,90\%, Álvares Machado, com 93,15\%, Indiana, com 90,23\%, Presidente Prudente, com 93,21 e Santo Expedito, com 90,36\%.

Por outro lado, no município de Sandovalina, as propriedades com até 100 hectares significam apenas 34,23\%, no de Rancharia 64,17\%, o que caracteriza, nestes municípios uma forte concentração de propriedades com áreas acima de 100 hectares, ou seja, $65,77 \%$ e $35,83 \%$ respectivamente. 
TABELA 16.1 EDR DE PRESIDENTE PRUDENTE - NÚMERO DE PROPRIEDADES COM ÁREA ATÉ 100 HA, 1995/1996

\begin{tabular}{|l|r|r|r|r|r|}
\hline \multicolumn{1}{|c|}{ MUNICÍPIOS } & \multicolumn{1}{c|}{$0-10$ ha } & \multicolumn{1}{c|}{$11-50$ ha } & \multicolumn{1}{c|}{$51-100$ ha } & \multicolumn{1}{c|}{ TOTAL } & $\begin{array}{c}\text { \% total entre áreas até } 100 \text { ha } \\
\text { / e maiores de 100 ha }\end{array}$ \\
\hline Alfredo Marcondes & 136 & 292 & 41 & 469 & 96,90 \\
\hline Álvares Machado & 220 & 555 & 82 & 857 & 93,15 \\
\hline Anhumas & 15 & 157 & 50 & 222 & 78,45 \\
\hline Caiabu & 105 & 195 & 36 & 336 & 89,60 \\
\hline Emilianópolis & 24 & 133 & 50 & 207 & 79.01 \\
\hline Estrela do Norte & 3 & 148 & 9 & 160 & 79,60 \\
\hline Iepê & 84 & 190 & 71 & 345 & 72,48 \\
\hline Indiana & 66 & 146 & 28 & 240 & 90,23 \\
\hline João Ramalho & 34 & 116 & 32 & 182 & 72,80 \\
\hline Martinópolis & 154 & 286 & 112 & 552 & 74,19 \\
\hline Nantes* & - & - & - & - & 74,59 \\
\hline Narandiba & 13 & 57 & 21 & 91 & 80,84 \\
\hline Pirapozinho & 82 & 149 & 39 & 270 & 82,71 \\
\hline Presidente Bernardes & 120 & 413 & 84 & 617 & 93,21 \\
\hline Presidente Prudente & 320 & 605 & 119 & 1044 & 64,17 \\
\hline Rancharia & 58 & 260 & 137 & 455 & 87,41 \\
\hline Regente Feijó & 93 & 203 & 58 & 354 & 34,23 \\
\hline Sandovalina & 5 & 23 & 10 & 38 & 90,36 \\
\hline Santo Expedito & 28 & 100 & 222 & 150 & 74,84 \\
\hline Taciba & 34 & 137 & 67 & 238 & 82,52 \\
\hline Tarabai & 33 & 108 & 29 & 170 & 82,34 \\
\hline TOTAL & 1627 & 4273 & 1097 & 6997 & \\
\hline
\end{tabular}

Fonte: Projeto LUPA/1997.

Nas figuras 9 e 10 estão agrupadas em mapas sínteses as informações contidas nas tabelas 16 e 16.1, com a localização de cada município, para melhor representar a estrutura fundiária do EDR de Presidente Prudente.

No período compreendido entre 1975 e 1995, é possível comparar, através da tabela 17, segundo os censos agrícolas do IBGE, a variação no número de estabelecimentos rurais por município do EDR pesquisado. 


\section{FIGURA 9 - ESTRUTURA FUNDIÁRIA - MUNICÍPIOS DO EDR DE PRESIDENTE PRUDENTE - SP}
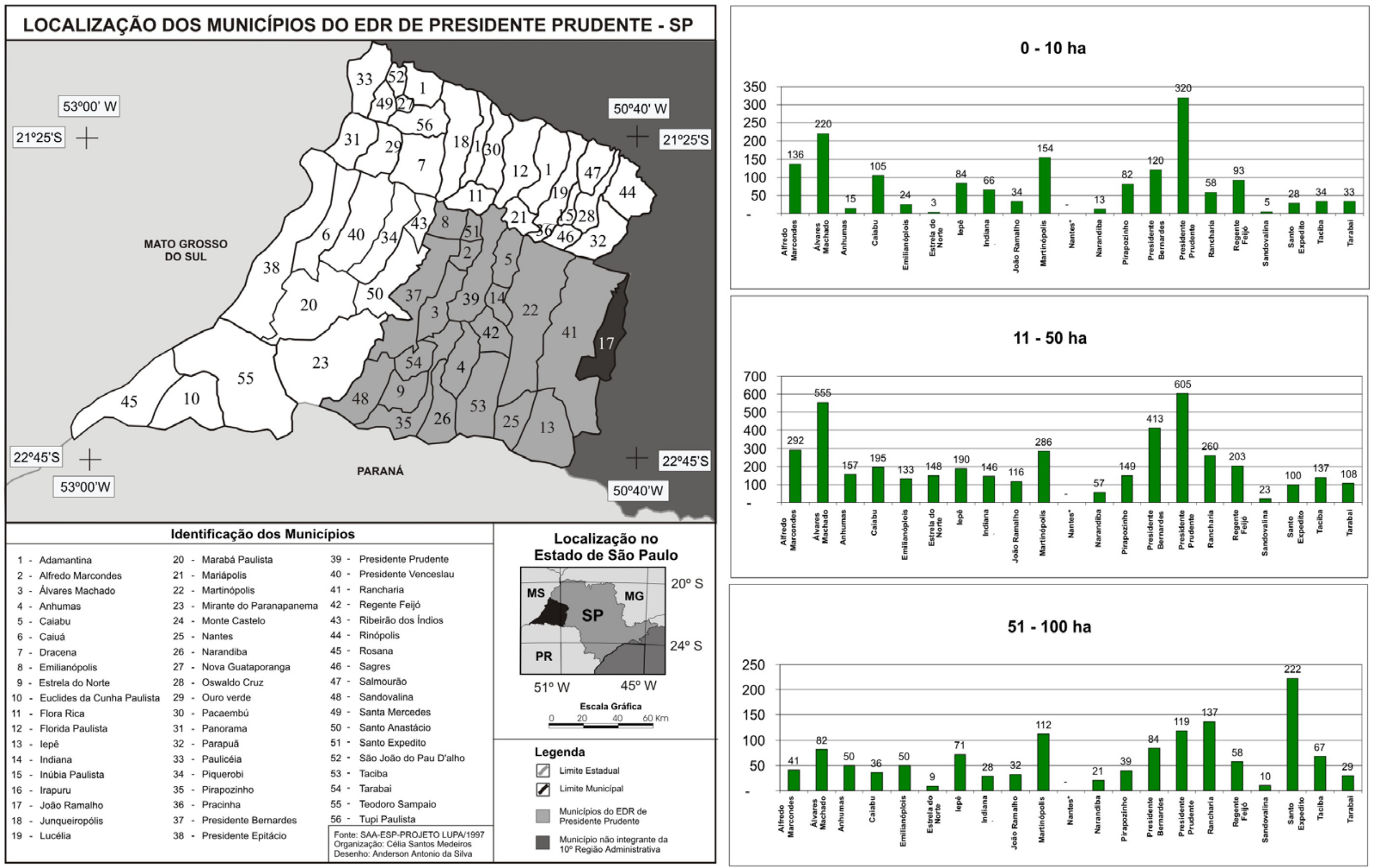


\section{FIGURA 10 - ESTRUTURA FUNDIÁRIA - MUNICÍPIOS DO EDR DE PRESIDENTE PRUDENTE - SP}

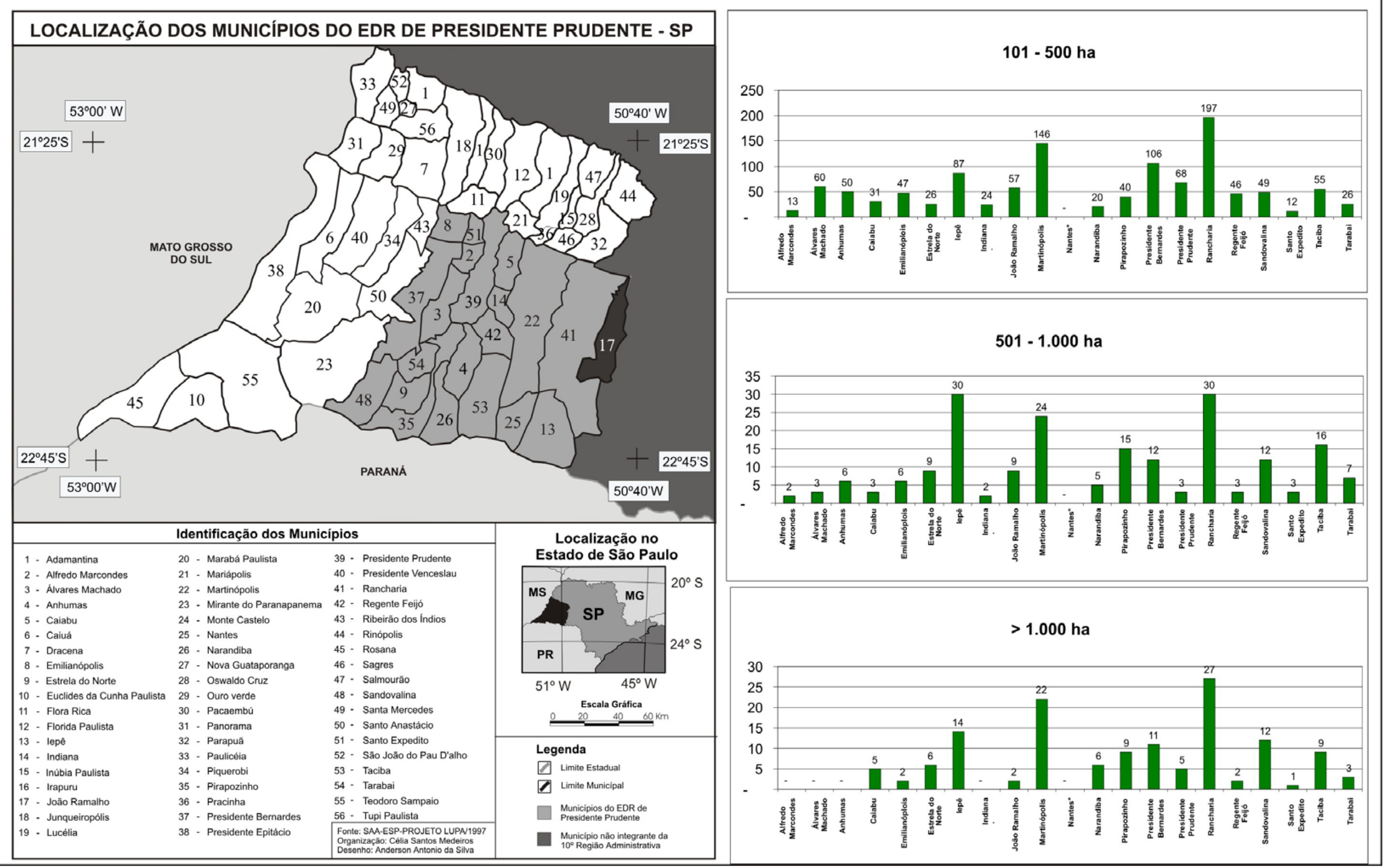


Desta maneira, houve uma diminuição, em números absolutos, de 2113 estabelecimentos nesse período; mais uma vez é apontada a concentração fundiária na maioria dos municípios analisados, exceto naqueles onde ocorreram desapropriação e posteriormente, assentamentos rurais, como por exemplo, demonstrado abaixo, para o município de Rancharia.

\section{TABELA 17. NÚMERO DE ESTABELECIMENTOS* RURAIS POR MUNICÍPIOS - EDR DE PRESIDENTE PRUDENTE} 1975 E 1995/96

\begin{tabular}{|l|r|c|}
\hline MUNICÍPIOS & 1975 & $1995 / 96$ \\
\hline Alfredo Marcondes & 471 & 484 \\
\hline Álvares Machado & 1.232 & 920 \\
\hline Anhumas & 310 & 283 \\
\hline Caiabu & 558 & 375 \\
\hline Estrela do norte & 294 & 201 \\
\hline Iepê & 589 & 476 \\
\hline Nantes & - & - \\
\hline Indiana & 303 & 266 \\
\hline João Ramalho & - & 255 \\
\hline Martinópolis & 1.177 & 744 \\
\hline Narandiba & 265 & 122 \\
\hline Pirapozinho & 591 & 334 \\
\hline Presidente Bernardes & 1.298 & 746 \\
\hline Emilianópolis & - & 262 \\
\hline Presidente Prudente & 1.165 & 1.120 \\
\hline Rancharia & 84 & 709 \\
\hline Regente Feijó & 488 & 405 \\
\hline Sandovalina & 169 & 111 \\
\hline Santo Expedito & 234 & 166 \\
\hline Taciba & 391 & 318 \\
\hline Tarabai & 239 & 8.503 \\
\hline TOTAL & & 206 \\
\hline & & \\
\hline
\end{tabular}

Fonte: Censo Agropecuário FIBGE-1975 e 1995/6

* relativa à unidade econômica (área cultivada) e não à unidade jurídica da terra

De fato, a concentração fundiária pode ser considerada um grande obstáculo para um dinamismo social e econômico da região, na medida em que impossibilita o acesso a terra por um número maior de pessoas que poderiam ter, então, a possibilidade de se reproduzir socialmente. 


\subsection{FORMAS DE CRÉDITO E FINANCIAMENTO DA PRODUÇÃO}

Como já foi tratado nessa pesquisa, os recursos financeiros disponíveis aos produtores rurais através do Sistema Nacional de Crédito Rural, implantado na década de 1960, não alcançaram, de forma semelhante, todos os níveis do setor agropecuário.

Ao contrário, eles privilegiaram, principalmente, os médios e os grandes produtores rurais, acentuando uma modernização desigual e excludente.

Essa política foi, então, a base da modernização da agricultura, como um instrumento de articulação e de convergência desses produtores rurais com o grande capital com interesses na agricultura, principalmente ramos industriais fornecedores e processadores da produção agrícola; os capitais de origem urbana, desejosos de aplicar capital produtivo na agricultura e na especulação de terras; os bancos e o Estado.

Como conseqüência dessa política, houve um aumento da concentração da propriedade da terra, e uma redução dos espaços ocupados pelos arrendatários, posseiros e outros pequenos produtores, trazendo com resultado uma migração rural sem precedentes, na qual cerca de 32 milhões de pessoas deixaram o campo, entre 1965 e 1985.

O cenário começou a mudar a partir da pressão de movimentos sociais e da Confederação dos Trabalhadores na Agricultura - CONTAG, culminando, em 1996, com a criação do Programa Nacional de Fortalecimento da Agricultura Familiar - PRONAF.

Após diversos ajustes e reformulações, as diretrizes e linhas de ação desse programa buscam contemplar a diversidade existente no interior da produção familiar, e é a principal política pública de apoio a esses produtores.

Ainda assim, o PRONAF não tem conseguido diminuir as diferenças sociais e econômicas no setor agrícola nacional, pois ele tem mantido uma lógica similar à de 1970, ao liberar o crédito por região, produtos e produtores.

Isso tem levado a uma concentração do volume de crédito na Região Sul, 50,7\% em 2000. Com relação aos produtos são privilegiados o fumo, com 12\%, e o milho, com 14,8\% dos investimentos (Anuário Estatístico do Crédito Rural do Banco do Brasil, 2000). 
O setor rural brasileiro, sempre marcado por interesses conflitantes, tem resistido a uma organização mais racional, na qual fossem privilegiados os protagonistas desse programa, ou seja, os produtores familiares.

Ao analisar-se o orçamento destinado ao crédito agrícola, os setores que fazem mais pressão, via entidades corporativas e extracorporativas, são os que conseguem ter acesso direto ao dinheiro disponível; por outro lado, os produtores familiares, que não fazem parte desses setores, não têm acesso ao dinheiro que lhes deveria ser destinado.

Outro aspecto a ser ressaltado é que os bancos que atuam com o crédito rural apresentam pouca tradição no atendimento às comunidades rurais, além de que a falta de informações sobre as regras do Programa e das normas operacionais acentuam as dificuldades de implantação dos financiamentos.

Dessa maneira, em 2002, dos 21 municípios que compõem o EDR de Presidente Prudente, foram priorizados com recursos para investimento em infra-estrutura somente 4 do total, a saber, Alfredo Marcondes, Álvares Machado, Emilianópolis e Presidente Bernardes.

Frente a essa realidade se faz urgente à realização de mudanças nesse sistema de crédito que o tornasse mais justo e adequado para os produtores familiares. 


\section{CAPÍTULO 8 - CARACTERÍSTICAS E DEPOIMENTOS DOS PRODUTORES FAMILIARES ENTREVISTADOS}

Ao propor a realização dessa pesquisa junto aos produtores familiares formulei dezesseis questões abertas (Anexo I) como um roteiro, nas quais busquei apreender características tanto voltadas para a família, como unidade social, que administra a reprodução social de seus membros em situações materiais e culturais distintas, quanto para aspectos como as formas de ocupação e o tempo na atividade agrícola; o uso da terra; o sistema de produção agrícola escolhido; técnicas e tecnologia; assistência técnica; formas de comercialização e destino da produção; uso de máquinas e equipamentos; formas de financiamento; as relações de produção; a renda familiar; o número de famílias que residem na propriedade; formas de organização social dos agricultores; fatores que facilitam e / ou dificultam a atividade agrícola; planos futuros com relação à atividade que desenvolvem; que serviços são utilizados fora da propriedade, com que freqüência e em qual cidade.

Procurei, desta maneira, levantar questões ligadas à unidade de produção, bem como à unidade social dos agricultores familiares.

Por tratar-se de questões abertas, muitas vezes não obtive respostas a elas, pois os informantes davam outras informações no decorrer da conversa e não voltavam àquele assunto; e, para não atrapalhar o relato, não os interrompia; por isso, algumas vezes, aparecem nas tabelas abaixo como "não respondidas”, não significando isso recusa deles em respondêlas.

Desta maneira, apresento, nesse capítulo, dados gerais relacionados aos entrevistados, e destaco algumas “falas”, mais significativas, dos entrevistados, que revelam, de maneira mais aprofundada, a realidade vivida por eles. As entrevistas estão disponíveis, na íntegra, também por produtor no Anexo 1.

Assim, após a análise dos dados gerais e das informações coletadas, tem-se, com relação à idade dos informantes: 
TABELA 18. IDADE DOS INFORMANTES

\begin{tabular}{|l|c|c|}
\hline IDADE DOS INFORMANTES & $\mathbf{N}^{\circ}$ & $\mathbf{\%}$ \\
\hline 20-40 anos & 17 & 27 \\
\hline $41-60$ anos & 32 & 51 \\
\hline mais de 60 anos & 14 & 22 \\
\hline TOTAL & $\mathbf{6 3}$ & $\mathbf{1 0 0}$ \\
\hline
\end{tabular}

Fonte: Trabalho de Campo, 2001.

Quando questionados sobre a idade e o tempo em que exerciam a atividade agrícola, mais da metade dos produtores entrevistados demonstraram, através de seus relatos, que dedicaram, praticamente, toda uma vida à prática agrícola,

Eu nasci na atividade [agrícola], meu pai era empregado... eu... [trabalho na agricultura] desde pequeno, estou há 18 anos por conta própria..., estou com 41 anos... e, foi aonde eu comprei aqui [município de Presidente Prudente]. Ele [o pai] trabalhava na agricultura, naquela época ele plantava amendoim, aí depois eu casei, né?...e aí eu comecei a plantar batata, aqui eu comprei com a batata, nós morávamos no $\mathrm{km} \mathrm{6}$, aqui pertinho, aqui tem 2 alqueires [A residência está nessa área]. (Produtor)

"Desde que nasci, desde pequenininho, né? Há 30 anos mais ou menos...” (Produtor), ou outro ainda: “Há uns 25 anos que eu trabalho na agricultura” (Produtor), ou ainda: “Desde que nascemos [são três irmãos], eu comecei a trabalhar com 8 anos, [tenho] ...30 anos já, ia à escola cedo, né? Vinha na escola e na parte da tarde...ajudava o pai”.

Assim, 51\% dos informantes têm entre 41 e 60 anos; os informantes entre 20 e 40, anos são 27\%; e, os acima de 60, anos representam 22\%. Observei que esses dados revelam um número considerável de mão de obra acima de 40 anos, 73\% do total, ou seja, a ausência de agricultores jovens e, conseqüentemente, um certo envelhecimento populacional no campo.

Essa realidade leva a estratégias familiares como, por exemplo, a necessidade de contratar mão de obra assalariada, embora isso dependa também de outros fatores. Ela pode ser permanente ou eventual para auxiliar na organização do processo produtivo, além da ajuda dos filhos, que, muitas vezes, ainda permanecem na propriedade.

A mão-de-obra fora a da família, é composta, geralmente, por trabalhadores que residem nas áreas “urbanas” próximas às propriedades, conforme se verá no item sobre relações de trabalho. 
Segundo relatado nas entrevistas, muitos produtores mostram-se descrentes ao relacionar a adoção de novas práticas e cultivos, de novas técnicas e tecnologia, às mudanças efetivas, sejam elas ligadas à produção ou ao preço na comercialização, pois o preço dos insumos é alto e a produção agrícola, quando comercializada, muitas vezes, não atinge o preço necessário para cobrir os custos da produção.

Com relação ao tempo em que estão atuando na agricultura, tem-se:

TABELA 19. TEMPO NA ATIVIDADE

\begin{tabular}{|l|c|c|}
\hline ANOS & $\mathbf{N}^{\circ}$ & $\mathbf{\%}$ \\
\hline $0-10$ & 8 & 13 \\
\hline $11-30$ & 17 & 27 \\
\hline $31-50$ & 25 & 40 \\
\hline mais de 50 & 13 & 20 \\
\hline TOTAL & $\mathbf{6 3}$ & $\mathbf{1 0 0}$ \\
\hline
\end{tabular}

Fonte: Trabalho de Campo, 2001.

“...trabalhamos de empregados mais ou menos trinta anos num sítio..., depois compramos e viemos pra cá, acho que daqui.., só carregado”. (Produtor, 64 anos)

Percebe-se trajetórias dos produtores que já foram trabalhadores assalariados e, posteriormente, por terem “acertado com a lavoura”, adquiriram uma área própria e nunca pensaram em mudar de atividade, tanto que do "sítio" só saem, como disse o produtor acima, “carregado”, isto é, morto.

"Eu estava na cidade e deu vontade de vim para o sítio, né? E eu enraizei e fiquei 20 anos, né? Eu tinha comércio de roupas, mais ou menos 10 anos.” (Produtor). Também ocorreu casos de pessoas entrevistadas que tiveram outra atividade na cidade durante um período de suas vidas, e que se mudaram pelo sonho de morar na área rural; outros tinham lembranças da origem familiar no campo e retornaram.

Nesta atividade [atual] eu já estou praticamente há 1 ano e 4 meses, estou hoje aqui por vários fatores que aconteceram na minha vida, né? E um dos maiores fatores é que eu gosto de plantar horta, eu sempre morei no sítio e a vida inteira eu andava nas hortas e admirava..., meu maior sonho era um dia plantar horta. (Produtor) 
O relato desse produtor, que nasceu no campo e ajudou o pai nessa atividade até a adolescência, mostra que o mesmo exercia a profissão de torneiro mecânico e por ter sofrido um acidente que o fez abandonar essa profissão, voltou a ser horticultor .

Pode-se então, através dos dados da tabela 18, verificar que $60 \%$ dos informantes exercem esse trabalho há mais de 30 anos, portanto, com muita experiência no que diz respeito a práticas e métodos, o que, por outro lado, pode revelar uma resistência à mudanças.

Ainda cabe destacar que a experiência na agricultura, contudo, muitas vezes não possibilita a superação dos limites encontrados pelo preço que a produção alcança na comercialização e mesmo como garantia para a obtenção de empréstimos.

\section{TABELA 20. ESCOLARIDADE DO INFORMANTE}

\begin{tabular}{|l|c|c|}
\hline ESCOLARIDADE & $\mathbf{N}^{\circ}$ & $\mathbf{\%}$ \\
\hline Superior completo & 1 & 1 \\
\hline Ensino médio & 5 & 7 \\
\hline Ensino médio incompleto & 7 & 12 \\
\hline Ensino fundamental & 15 & 24 \\
\hline Ensino fundamental incompleto & 10 & 16 \\
\hline Não respondeu & 25 & 40 \\
\hline TOTAL & $\mathbf{6 3}$ & $\mathbf{1 0 0}$ \\
\hline
\end{tabular}

Fonte: Trabalho de Campo, 2001.

Eu estudei até a $4^{\text {a }}$ série do primário, a gente morava aqui no sítio vizinho, eu terminei aqui numa escolinha de sítio que é até só a $4^{\mathrm{a}}$ série do primário, aí, na época que terminamos o primário, a mãe foi na cidade e comprou o uniforme, comprou o material e cruzamos os braços e ficamos esperando o ônibus que o prefeito prometeu que ia mandar..., e ficamos esperando um bom tempo e nunca veio, o meu pai não tinha condição de levar todo dia, a gente num tinha meios, somos 6 [irmãos]. (Produtor, 37 anos)

Através da "fala” deste produtor, pode-se notar as dificuldades encontradas pelas famílias em proporcionar aos filhos uma escolaridade mais elevada e, nesse caso, elas revelam o descaso da administração pública municipal em atender a solicitação dos cidadãos.

Assim, no que diz respeito à escolaridade dos informantes, nota-se que a mesma é baixa, pois somente um deles tem curso superior; 7\% dos entrevistados possuem o ensino médio completo; $12 \%$ não terminaram o ensino médio; 24 \% completaram o ensino fundamental; e, 16\% não o completaram. 
Essa baixa escolaridade foi justificada também pelos entrevistados mais velhos pela necessidade de ajudar os pais na unidade de produção na infância e juventude, e mesmo pela pouca valorização que era dada, então, aos estudos. Entretanto, entre os mais jovens, percebemos que todos os filhos estão estudando ou já terminaram, pelo menos, o ensino médio.

Algumas vezes ouvi que era fundamental que o filho tivesse um "diploma” que o ajudasse no futuro, caso o trabalho na agricultura não fosse suficiente para o seu sustento; e, outras vezes, eles relataram que já tinham filhos (jovens) que trabalhavam na cidade e que não tinham planos de retomar ou seguir a profissão dos pais.

TABELA 21. FORMAS DE ACESSO À TERRA

\begin{tabular}{|l|l|l|}
\hline FORMAS DE ACESSO À TERRA & $\mathbf{N}^{\circ}$ & $\mathbf{\%}$ \\
\hline Compra & $28^{*}$ & 44 \\
\hline Herança & 24 & 38 \\
\hline Compra e herança & 11 & 18 \\
\hline TOTAL & $\mathbf{6 3}$ & $\mathbf{1 0 0}$ \\
\hline
\end{tabular}

Fonte: Trabalho de Campo, 2001.

*Dos informantes que relataram terem comprado suas terras, sete declararam que possuem, simultaneamente, arrendamento.

A forma de acesso à terra pode ter sido por herança, que, com a divisão da propriedade, possibilitou a permanência dos herdeiros numerosos, ainda que em áreas menores, conforme o relatado a seguir,

É herança, pegamos do avô, que veio de Minas [Gerais], Guaxupé, toda a fazenda acho que era 200 alqueires, dividida entre os herdeiros, 42 hectares para cada um. Nós [três irmãos casados e suas famílias] estamos trabalhando nesta área desde então, desde mocinhos..... faz uns 13 anos que nós começamos a arrendar terra [de] fora. (Produtor, 42 anos)

Nota-se, nesse relato, a evidência de que a dimensão de unidade de produção foi durante um período suficiente para garantir o sustento das famílias e que, posteriormente, a divisão por herança, acarretando uma diminuição das áreas produtivas, levou os produtores familiares a arrendarem terra, para aumentar de produção.

Esse aumento só foi possível através do arrendamento de terras que, se por um lado, possibilitava um aumento da área plantada por parte do agricultor, por outro, era conveniente ao pecuarista que tinha, com essa prática, sua pastagem reformada, sem despesas. 
[...] meu avô se estabeleceu aqui na região, daí ele foi ficando e trabalhando conseguiu comprar esse sítio e criou toda família aqui, sempre na região de Prudente, sempre vivemos da agricultura, o que ele tem hoje foi tudo da agricultura, criou os filhos agora se aposentou.[..] (Produtor)

Neste depoimento, o avô do produtor familiar era trabalhador assalariado e, posteriormente, comprou o sítio e “criou toda família”, sempre através do trabalho na agricultura.

Outros entrevistados sempre foram arrendatários e só recentemente, com a renda da produção, puderam adquirir terra própria, “...esse ano [2001] consegui comprar uma [área], fui juntando, juntando e consegui comprar uma propriedade, 10 alqueires [24 hectares], agora vou passar a plantar nela.” (Produtor)

[...] Isso aqui meu pai comprou há mais ou menos 25 anos..., a gente morava no Paraná, plantávamos café lá e foi quando a gente conseguiu dinheiro, e compramos aqui, ele já tinha morado antes na região [de Presidente Prudente], [o pai] nasceu aqui, foi para o Paraná e depois voltou. Na década de 70, [aqui] era café e pasto. (Produtor)

Pode-se destacar aqui a mobilidade dos produtores, que saíram da região de Presidente Prudente, movidos pela possibilidade de melhores oportunidades. Eles vão para outros estados trabalhar na lavoura e posteriormente, retornam e compram uma propriedade, onde os filhos permanecem até hoje. Esse fato revela que, em outros lugares, eles encontraram condições mais favoráveis para sua reprodução social naquele período do que encontrariam na região de origem.

Fica evidente, assim, a questão da mobilidade como propulsora da estratégia de desenvolvimento capitalista que, ao separar o trabalhador de seus meios de existência, leva-o a sair em busca de trabalho. O assalariamento é, assim, uma das etapas de seu processo de reprodução, e como já foi ressaltado neste trabalho, destacam-se o papel do Estado e de suas políticas nesse processo.

No total dos entrevistados, pode-se observar que, nas formas de acesso à terra, $44 \%$ as adquiriram e 38\% receberam por herança. É possível afirmar que esses 28 agricultores familiares que compraram terras são, na maioria, aqueles mais velhos, ainda responsáveis pela unidade de produção. Por outro lado, os 24 agricultores que a receberam como herança, caracterizam-se por serem aqueles que deram continuidade à atividade, 
possibilitando a reprodução social familiar na unidade de produção. Muitas vezes, na mesma unidade, residem mais de uma família, como se pode notar na tabela 21.

\section{TABELA 22. FAMÍLIAS QUE RESIDEM NA UNIDADE DE PRODUÇÃO}

\begin{tabular}{|l|c|c|}
\hline NÚMERO DE FAMÍLIAS & $\mathbf{N}^{\circ}$ & $\mathbf{\%}$ \\
\hline 1 & 29 & 46 \\
\hline 2 a 3 & 31 & 49 \\
\hline mais de 3 & 3 & 5 \\
\hline TOTAL & $\mathbf{6 3}$ & $\mathbf{1 0 0}$ \\
\hline
\end{tabular}

Fonte: Trabalho de Campo, 2001.

Conforme o número de famílias que residem na unidade de produção, a faixa de 2 a 3 famílias representou 49\% do total, enquanto não menos significativas são aquelas unidades de produção em que somente uma família é residente. Tal fato se dá, segundo o relatado, devido à saída dos filhos ou por ser a área insuficiente para dar sustento a mais de uma família, ou mesmo pela opção do(s) filho(s) em seguir (em) outra profissão.

Com relação à renda familiar, os produtores entrevistados relataram que a maior parte dela vem da agricultura; entretanto, existem também aqueles que recebem aposentadoria, ou algum familiar exerce outras funções nas áreas urbanas próximas, para complementar a renda.

TABELA 23. PRINCIPAL FONTE DE RENDA FAMILIAR

\begin{tabular}{|l|c|c|}
\hline PRINCIPAL FONTE DE RENDA FAMILIAR & NÚMERO & $\mathbf{\%}$ \\
\hline Comercialização da produção e aposentadoria & 24 & 39 \\
\hline Comercialização da produção & 22 & 35 \\
\hline Comercialização da produção e outra atividade & 2 & 3 \\
\hline Outra profissão & 6 & 9 \\
\hline Não respondeu & 9 & 14 \\
\hline TOTAL & $\mathbf{6 3}$ & $\mathbf{1 0 0}$ \\
\hline
\end{tabular}

Fonte: Trabalho de Campo, 2001.

Somos 3 famílias, eu, meu irmão e um filho casado [morando na propriedade]. Uma das fontes de renda que a gente tem mesmo de mensalidade mais ou menos é só o leite, porque a roça é..., só na colheita, ...[Pergunto se dá pra guardar algum dinheiro].... Guardar dinheiro... não, não. Médico, nós usamos pela cooperativa [COOLVAP], nós pagamos UNIMED pra todo mundo, a gente às vezes tem de arrumar dinheiro pra tocar..., a agricultura não está se pagando ela mesma, não está. 
Agora a senhora podia fazer uma pergunta: Por que não pára? Aqui são 3 famílias se eu parar... eu acho que o bicho pega se eu correr..., a gente só sabe fazer isso daqui, então, vamos arriscando até um dia... vamos perder o que temos ou vamos dar uma acertada em alguma coisa que a gente tenha ou dar uma equilibrada, mas que a situação é..... Isso da gente sobreviver, isso eu acho bom porque a gente tem fartura de tudo, quer dizer aqui ninguém tem luxo de nada, de roupa boa, de sapato, vai meio de qualquer jeito, né?(Produtor)

Percebe-se, através deste relato, o quanto de incerteza o produtor familiar demonstra com relação aos fatores que possibilitem a sua reprodução social.

“Tudo [a renda familiar] vem da agricultura e do leite, eu tenho um menino que já está fora, 17 anos, mora com a avó dele lá em Anhumas, trabalha lá, num escritório... A mãe e o pai são aposentados,[ao todo são] 4 famílias, com meu pai” (Produtor).

Nesse caso, um dos filhos já está exercendo uma atividade fora da unidade produtiva; conforme o relatado, nem sempre é possível atrair o jovem para dar continuidade ao trabalho familiar no campo, ou nem mesmo o pai acredita que o filho possa "sobreviver" desse trabalho. Outras vezes, a esposa contribui com uma parte da renda ao exercer outra atividade, fora da atividade agrícola:

“A minha esposa ajuda [com] uns $20 \%$, o resto, $80 \%$ é [proveniente] da agricultura mesmo, no caso hoje eu estou trabalhando com batata doce” (Produtor).

A dimensão da propriedade e a dificuldade em aumentar a área plantada são fatores que limitam a permanência de muitas famílias nas unidades de produção ou na atividade agrícola:

[Trabalham nesta área] Meu pai e eu, meus irmãos já estão fora, porque a propriedade do meu pai é pequena, não tem como trabalhar em cima dela, dependendo da atividade que vai desenvolver até funciona (morar mais gente na propriedade) né? Agora, no caso, a gente planta a batata e a batata precisa de bastante terra, porque não é tão rentável, então você tem que ter [terra] em quantidade, tem que plantar bastante para ter um volume de produção e daí ter lucro, e... sem contar que podemos fazer no máximo 2 plantas na mesma terra, depois tem que já trocar de cultura, plantar um capim pra descansar...e então acaba que tem que estar sempre mudando, então a propriedade pequena pra esse tipo de lavoura não funciona, a gente tem que estar sempre mudando... [a área plantada] (Produtor).

Outros relatam que só têm como fonte de renda a comercialização da produção. Assim, 
Trabalhamos tudo em cima da agricultura [a renda vem toda da agricultura],a nossa compra, a nossa roça... [os insumos] tudo vem da agricultura. Aqui onde nós moramos, somos eu e o meu irmão [com suas famílias], o meu pai é vizinho, meus irmãos moram fora, só a gente mesmo que mora aqui. (Produtor)

A aposentadoria é destacada, às vezes, como a renda principal, entre outras:

O que ajuda mais [na renda] é a aposentadoria do meu marido porque a minha é um salário só, também tinha casa de aluguel (duas), tinha telefone... em 6 anos foi tudo aí... [na atividade agrícola], a renda daqui é muito pouca, nós ficamos aqui até agora porque tem aposentadoria e tem essa casa aqui, mas agora nós vendemos a casa também e estamos aplicando [o dinheiro] (Produtor).

Esses produtores estão de mudança, arrendaram o sítio para ser usado como área de lazer e vão residir na cidade de Prudente; os filhos, que moram em São Paulo, estão preocupados com os pais, devido à idade deles.

Já para esse produtor familiar,

A participação [da agricultura na renda familiar] é praticamente toda da horta... tudo que a gente compra aqui é [com a renda] da horta, por exemplo: material [escolar] para as crianças, a despesa com a perua [Kombi, usada para transportar a produção], gasolina, empregados, energia elétrica, adubo, semente..., tudo a gente consegue através da venda que a gente faz das verduras aqui da horta, não tenho outra atividade, nem outra renda. (Produtor)

Quanto às áreas das unidades visitadas obtive o seguinte quadro:

TABELA 24. ÁREA DAS UNIDADES DE PRODUÇÃO VISITADAS

\begin{tabular}{|l|l|l|}
\hline ÁREA - ha & $\mathbf{N}^{\circ}$ & $\mathbf{\%}$ \\
\hline Até 20 & 17 & 27 \\
\hline $21-40$ & 19 & 30 \\
\hline $41-60$ & 11 & 17 \\
\hline $61-80$ & 6 & 10 \\
\hline mais de 80 & 10 & 16 \\
\hline TOTAL & $\mathbf{6 3}$ & $\mathbf{1 0 0}$ \\
\hline
\end{tabular}

Fonte: Trabalho de Campo, 2001.

Desta forma, pode-se observar que 27\% delas possuem até 20 hectares; $30 \%$ se situam entre 21 e 40 hectares; $17 \%$ estão entre 41 e 60 hectares e, $26 \%$, têm mais de 60 hectares. Tal realidade demonstra que, inclusive em áreas consideradas pequenas, estes 
agricultores têm conseguido produzir e se reproduzir, mesmo diante das limitações relatadas nas entrevistas; entretanto, todos gostariam de contar com mais área para suas atividades produtivas.

A prática do arrendamento, dependendo da cultura adotada, é a maneira mais usual que o produtor familiar encontra para aumentar a área produzida.

Conforme declarações dadas nas entrevistas, alguns deles não encontram dificuldades para arrendar; entretanto, outros disseram que terras para arrendamento têm se tornado cada vez mais escassas.

A diminuição dessa forma de produção, já tratada no capítulo 6, ressalta mais uma limitação para o produtor familiar, que se vê pressionado pela necessidade de aumentar a área plantada, mas enfrenta problemas de ordem fundiária, de ordem financeira, aliados à falta de organização, enquanto grupo, e de políticas públicas para a agricultura, que pudessem modificar esse quadro.

A aquisição de terra é outra forma de aumentar a área; contudo, seu preço é elevado e, muitas vezes, a característica do solo e o seu potencial agrícola não compensam o preço que se pede por ela. Por outro lado, o produtor, muitas vezes, não dispõe de capital necessário para adquiri-la.

O sistema de produção será tratado aqui como o modo pelo qual se organiza a produção agrícola, isto é, como produzem, quais são e os porquês das escolhas feitas pelos produtores familiares.

Assim, na tabela 24, têm-se os tipos de atividades exercidas pelos produtores entrevistados; embora estejam colocadas de forma separada, o produtor pratica várias delas simultaneamente, como é possível ler nos relatos citados. 
TABELA 25. SISTEMA DE PRODUÇÃO

\begin{tabular}{|l|c|}
\hline ATIVIDADE & N $^{\circ}$ DE PRODUTORES \\
\hline Pecuária de leite & 37 \\
\hline Pecuária mista corte e leite & 1 \\
\hline Laticínios & 1 \\
\hline Fruticultura & 4 \\
\hline Horticultura & 3 \\
\hline Melancia & 1 \\
\hline Floricultura & 4 \\
\hline Feijão & 18 \\
\hline Milho & 2 \\
\hline Soja & 7 \\
\hline Batata doce & 2 \\
\hline Mandioca & 6 \\
\hline Cana de açúcar & 5 \\
\hline Café & 1 \\
\hline Uva & 5 \\
\hline Outros* & 2 \\
\hline
\end{tabular}

Fonte: Trabalho de Campo, 2001.

* Cabotchã, Napie, Criação de Cavalos, Arroz, Algodão, Mudas, Bicho-da-Seda, Escargot, flores,etc.

A terra é assim... ultimamente plantei tudo capim, mas depois a gente
quis plantar uma lavourinha não achamos terra por fora, então acabei
mexendo aqui mesmo, e acho que nós temos uns quatro alqueires
tombados, e o resto é pastagem [para gado de leite], mas só que nós
pegamos terra fora, né? [Arrendam]... No passado estava até melhor
porque hoje não está fácil [arrendar terra], porque eu acho que o
fazendeiro tem até razão porque ele precisa da terra, né, a fazendeira
(vizinha) “me deu terra" este ano e até a gente não ganha... dinheiro, nós
[até que] fizemos bastante, mas não ganhamos [mais] por causa dos
insumos, das coisas que são muito caras, né? E no fim não tem preco o o
que a gente vende... Aqui são vinte cinco hectares, a gente usa assim
talvez uma planta [cultura agrícola] e volta o capim outra vez, né? Hoje
tem uns 4 alqueires mexidos, né? Plantei tomate, depois plantei um
pedaço de feijão e vou plantar tomate outra vez. Um pedaço que tem de
tomate é na fazenda aqui que nós tomamos conta, a dona é de
Piracicaba... Aqui tudo é aproveitado [a área toda]. (Produtor)

É interessante notar no relato dos entrevistados as relações de subordinação ao produtor pecuarista por este ter mais terra, podendo "dar de renda" ao pequeno produtor que, visto de forma superficial, esconde nesta relação um custo, seja em dinheiro, pelo aluguel da terra, seja em trabalho, ao deixar a pastagem reformada depois da colheita. 
Outras “falas” revelam um "planejamento" da produção por parte de alguns produtores familiares entrevistados, como pode ser observado a seguir:

Nós plantamos um pedacinho de tomate [ciclo de 90 dias] lá no sítio, então a gente começou em janeiro, né? Depois, já comecamos a preparar, outra área pra plantar feijão e abóbora, plantamos em março, acabamos de colher o tomate e replantamos abóbora, a abóbora [o ciclo] também é uns 90 dias, [E hoje?] Nós estamos mexendo com a melancia, depois nós estamos querendo plantar em uma área que estamos querendo reformar [a pastagem] lá no sítio nosso, para plantar em setembro... para plantar melancia, também para colher no fim do ano, em novembro... no Natal, a gente pensa só de ficar [sem plantar nada] aí dezembro.... e janeiro. Janeiro a gente já começa a mexer com tomate, né? Parado mesmo, praticamente só o mês de dezembro, né?... Ainda do dia 15 em diante, porque hoje em dia não pode ficar parado muito tempo, né? (Produtor)

O relato abaixo revela como o produtor vai formando seu rebanho, sem preocupação com a sua melhoria genética, e também o fato de que ele vai “experimentando”, isto é, sem orientação mais técnica ou especializada:

O gado... fomos comprando aos poucos, cruzado, né? Compramos um boi puro para a gente ir fazendo [o cruzamento] o gado, né? Para gado de leite foi muito pouco comprado, né? Vamos criando..., vai apurando aos poucos, né? Agora lá [nós estávamos em área de arrendamento, fora da propriedade onde as famílias residem] é tudo pasto, né? [...] mas tem a reserva, né? São 3 alqueires, o pasto é de brizantão, mambaça, vai aparecendo capim novo, né? Vai mudando né? A gente vai experimentando o caminho todo, né?, lá não tem cultura, agora não. (Produtor)

Segundo veterinários e técnicos, esse aprendizado na "prática” pode levar, por exemplo, a uma baixa eficiência do rebanho, demonstrada pela baixa produção leiteira, a qual elevaria os custos da produção, entre outros fatores.

A questão das culturas adotadas pelos produtores demonstra que eles sempre estiveram sujeitos ao mercado. Assim, diz o entrevistado que,

$\underline{0}$ pequeno tem que sair procurando alternativas, já passou o algodão, passou o milho, o amendoim, foi acabando e o pessoal agora partiu pra batata doce.., aí veio a mandioca, como sendo a salvadora da pátria, no final não está tendo nem preço, você viu o pessoal, coitados, plantaram mandioca... aí perderam, não vai nem colher, porque não compensa, tem que pagar pra colher [...].O preço num dá pra você falar: eu vou plantar batata pra vender a 10 reais a caixa, já foi vendido [a esse preço] [...] mas é aquela coisa passageira, né? Hoje está 3 reais, já foi a menos de 1 real a caixa, porque a menos não dá pra você mandar, o preço da embalagem custa 1,5 , aí você não manda, aí perde... e aí você vai ver o problema que você tem, dar fim naquilo, você não pode largar aquilo [a produção] lá, porque aí o arrendador vai querer a terra ou mesmo que ele não for arrendatário, for o dono da terra ele tem que dar fim naquilo. (Produtor) 
FOTOS 1 E 2 
Para alguns, o sistema de produção adotado é a pecuária de leite, conjugada com uma cultura agrícola, definida pela demanda e pelo preço do mercado,

Aqui são 14 hectares, metade $(7 \mathrm{ha})$ é pasto e metade $(7 \mathrm{ha})$ é plantação. A gente uma vez planta num lugar outra vez no outro, sempre...Tem hortaliças e agropecuária de leite, como a área é pequena não dá pra engordar. Sempre foi assim, uma parte é leite e outra parte é agricultura. Quando a gente começou a plantar... era café, mas já plantou de tudo...algodão, feijão, milho, arroz e depois começou a plantar com mais freqüência hortaliça...legumes: berinjela, jiló, vagem, quiabo, abobrinha, pepino. A gente decide mais ou menos na hora, de repente vê assim o que está melhor, o que está girando melhor, pelo preço, quando o preço vê que está melhorando, coisa e tal... eu conheço mais de plantar é berinjela..., milho [silagem ou ração para o gado leiteiro e milho verde, para comércio].

Outros, ainda buscam a especialização,

Eu sou horticultor, a única fruta que a gente planta e que eu tenho planos de aumentar a produção é o moranguinho, [...]. A gente planta alface, almeirão, couve, rúcula, chicória, cebolinha, salsinha..., tudo isso aí em bandeja de isopor, mudinha por mudinha para depois você levar para os canteiros. (Produtor)

Esse horticultor se especializou na produção de berinjela e de jiló.[Qual é o ciclo da berinjela?] Bom, desde a semeadura até a produção são 90 dias, [e o jiló] é a mesma coisa; a época dela é o ano inteiro, só tem que ter água [Você tem irrigação?] Tenho, comprei com o próprio dinheiro da hortaliça.

Nota-se, então, que o sistema de produção adotado pelos produtores entrevistados apresenta grande diversidade, conforme observado no relato anterior; isso se explica como uma estratégia de sobrevivência econômica da atividade agrícola e a possibilidade de reprodução social. Os dados levantados na pesquisa de campo demonstraram que a produção está assentada, principalmente, na criação de gado leiteiro, juntamente com uma ou mais cultura comercial.

Desta forma, ressalta-se que, dentre os produtores entrevistados, 59\% declararam que têm tido como atividade a pecuária de leite, ao lado de outra atividade agrícola.

O leite proporciona uma rentabilidade mensal, ao ser comercializado com a COOLVAP, com outros laticínios da região ou diretamente com os consumidores. 
Já as culturas, cada uma tem sua sazonalidade, isto é, a época do ano, o período do plantio até a colheita, o volume final da produção, e a rentabilidade vai depender dos custos para a produção e da comercialização. O milho e a cana, por exemplo, são usados tanto para comercialização quanto na alimentação dos animais.

Cabe destacar, ainda, que as áreas de arrendamento são usadas, geralmente, no grupo pesquisado, para a agricultura,

[...] arrendar terra não é difícil, o pessoal já conhece e pelo tipo de procura também [o uso da] a terra é... rápido, né? Ficamos 2-3 anos, não ocupamos [a terra] muito [tempo], que nem nós estamos arrendando aqui, quando for no fim do ano já entregaremos, às vezes pra fazer um contrato a gente precisa abrir inscricão, talão de nota, a gente obriga [o produtor] fazer um contrato para fazer inscrição. [Depois que colherem a melancia] aqui [o lugar em que nós estávamos, era área arrendada] nós vamos deixar tudo preparado, ajudar ele [o proprietário] a preparar a terra, a tombar a terra, ...depende do acordo..., que é feito na hora, né? Pela cultura que a gente planta é uma vez só, geralmente é desse tipo aqui o acordo..., lá na propriedade só tem pecuária de leite e fora ...lá antigamente era café, hoje não tem mais nada”.(Produtor)

Apesar de a prática do arrendamento oferecer uma alternativa, pode-se perceber que, se puder, o produtor prefere não depender dela.

A partir desse ano vou plantar nela [na área que comprou dos primos] pra fugir da renda, por que não tem como você pagar a renda, quer dizer, ás vezes até fica interessante você pagar a renda, só que você não consegue a terra pra plantar ou nas condições que você precisa, né? Vou arrendar a terra mas só pra tal período, né? Ou pra você plantar tal coisa, ou você tem que fazer uma coisa que.... fica sujeito ao que o dono da terra quer, impõe condicões que às vezes não tem como você cumprir, então para isso cada um vai ter que ter sua propriedade, então eu estou tendo assim uma esperança... que vai ser melhor, vou fugir da renda, né? Vou plantar no que é meu, não vou depender de prazo, né? Porque você pega a terra, e a pessoa quer um prazo, né? (Produtor)

Nota-se, ainda, mais detalhes sobre os contratos de arrendamento descritos pelos produtores entrevistados, bem como as dificuldades desta prática,

A área que nós produzimos é uma média de 30 alqueires, essa área é arrendada, nossa mesmo é só $1(\mathrm{um})$ ha, a produção nossa é sobre terra arrendada. Hoje está muito difícil (arrendar terra) porque quem arrenda quer receber á vista, né? Recebe antes de você mexer na terra, $e$ a renda hoje está MUITO cara, são 500 reais o alqueire. [Por quanto tempo?] Você arrenda a combinar, né? Você combina com o dono da terra, o proprietário, e se der pra fazer 2 plantas, sorte, mas nunca dá pra fazer 2 plantas, por ano, o tempo é a combinar, porque a partir do 
FOTOS 3 E 4 
dia que você pegar, você tem o prazo de 1 ano, depois tem que entregar. Aí a gente pega a terra, né?, quando chega no final do ano que você combinou, passado o contrato tudo, daí você entrega a terra gradeada pra ele, ele joga a semente. Os $\mathbf{5 0 0}$ (reais) é pelo período todo, você paga quando entra na terra, você faz um contrato porque você precisa dele, vamos supor, pra levantar um dinheiro no banco, então fazemos um contrato (formal). (Produtor)

E ainda este,

Não planto nada aqui [a área é insuficiente]. Eu arrendo terra por fora, nestes 18 anos sempre arrendei, [agora] está muito difícil (arrendar)....é muito difícil, o preço é muito alto e também falta terra disponível pra gente poder plantar, você "bate" [procura] em 10 donos de terra pra conseguir arranjar, às vezes a gente passa um contrato por causa do talão do produtor, um contratinho [...], o preco tem de duas formas que eu conheço, ou você paga à vista ou você planta o capim... por ano ou até por planta. Aqui tem gente pagando 500 até 700 reais por planta, você só planta uma vez essa batata e depois você vai embora, você a pega no gramão, aí você prepara ela e planta a batata, dentro de uns 6-7 meses,... colhe e larga a terra sem capim, agora quando você pega a troco [?] do capim aí é diferente, porque você não paga nada e planta o capim depois. Sou arrendatário na agricultura, só trabalho com agricultura. (Produtor)

O agricultor tem, assim, que arcar com o aluguel da área mesmo antes de têla utilizado, e, nesses casos, pode transferir para o proprietário tanto a renda em dinheiro quanto em trabalho, ao gradear a terra ou plantar o capim.

Nesta pesquisa, como já foi citado anteriormente, procurei conhecer, através dos depoimentos, as técnicas e as tecnologias adotadas, a assistência técnica recebida, assim como quais máquinas e equipamentos são utilizados pelos produtores familiares.

Desta forma, no que diz respeito à assistência técnica, a tabela 25 mostra que 22\% dos produtores familiares declararam utilizá-la da Casa da Agricultura; 18\%, da COOLVAP; $12 \%$ de particular e, um dado interessante, é que $12 \%$ disseram tê-la de vizinhos e amigos, e $27 \%$ não responderam a sobre a questão. 
TABELA 26. ASSISTÊNCIA TÉCNICA

\begin{tabular}{|l|c|c|}
\hline ASSISTÊNCIA TÉCNICA & $\mathbf{N}^{\circ}$ & $\mathbf{\%}$ \\
\hline Particular & 7 & 12 \\
\hline Cooperativa & 12 & 18 \\
\hline Casa da Agricultura & 14 & 22 \\
\hline Cooperativa e Casa da Agricultura & 4 & 6 \\
\hline Agrônomo do banco & 2 & 3 \\
\hline Outros (vizinhos e amigos) & 7 & 12 \\
\hline Não respondeu & 17 & 27 \\
\hline TOTAL & $\mathbf{6 3}$ & $\mathbf{1 0 0}$ \\
\hline
\end{tabular}

Fonte: Trabalho de Campo, 2001.

Com relação às técnicas, os produtores demonstram ter conhecimentos básicos e fazem uso delas; contudo, os relatos apontam outros problemas, como se pode observar,

[Com relação à conservação do solo] a gente faz curva de nível, tem irrigação para as lavouras que a gente planta, não todas, usa [água] daí dessa represa quem fez foi a fazenda [que ele toma conta], somos nós que tomamos conta da fazenda e ela dá um pedaço de terra pra eu usar e a gente ocupa a água da represa, disseram que hoje já está um problema também esse negócio de água, né? [...] porque já estão falando que vão cobrar água da irrigação, eu acho que cada vez vai ficar pior. (Produtor)

Há o temor de que o controle e a cobrança do uso dos recursos hídricos para a agricultura possam onerar ainda mais o produtor.

Com relação à assistência técnica, os produtores declararam que se utilizam desse serviço; contudo, o agrônomo ou o técnico, por vezes, não atende as necessidades específicas de cada produtor,

[...] a gente usa a Prefeitura e Casa da Lavoura do município, [mas é] pouco, pouco, inclusive agora tem um agrônomo que até,.. a gente conversa com ele, ele fala... $O$ que precisar a gente vai lá.. Antes da colheita vinha um agrônomo aí, um dos melhores que tem, [...] mas só que ele vinha um pedaço do dia, dois pedaços de dia na semana e era muito entendido,... mas entendido em parte, em parte o que a gente precisa eles também não entendem, por exemplo: se a senhora plantar tomate e chamar um cara desses não adianta.....é pior do que nós, agora ele para uma pastagem, uma coisa e outra, ele era bom.... Então, cada agrônomo eu acho que tem sua... qualidade e se especializa nessa coisa. Agora, parte de técnico a gente tem bastante..... o ano passado eu comprei adubo lá [na Associação de Palmitalzinho]. Esse ano eu já não comprei, nós temos o técnico... Tem vendedor de adubo, veneno, eles passam aqui...e se a gente liga pra eles também, eles vem ver. [...] eu sei 
FOTOS 5 E 6 
lá... agora, eu nem posso falar nada...porque um agrônomo na cidade... ele é especializado numa coisa, agora por exemplo, eu tenho tomate se eu chamo ele aqui e ele não entender de tomate eu nem vou chamar porque....então eu já tenho de pegar esse cara que a gente já é acostumado com ele, ou o vizinho que é plantador velho vem dar uma explicação pra gente... mas hoje a gente tem que usar um agrônomo porque hoje as doenças mudam muito, né? (Produtor)

$\mathrm{Ou}$, mesmo quando os produtores precisam comprar adubo, defensivos ou medicamentos veterinários, eles recebem orientação de agrônomos ou de técnicos agrícolas, que trabalham nesses estabelecimentos comerciais,

Fazemos análise, só trabalhamos em cima de uma análise, fazemos calagem, curvas de nível, usamos irrigação. [E assistência técnica?] Aí está o problema...não tem...assistência técnica não tem, essas casas que vendem insumos aí tem agrônomo, né? Não servem muito de base, né? Porque eles têm interesse também em venda [...] É complicado, né? Nós não sabemos se eles estão falando a verdade ou se querem vender os produtos deles, né? (Produtor)

Por vezes, os produtores entrevistados se mostraram descontentes com o preço dos serviços e dos insumos agrícolas,

A gente, até que tem...[preocupação com técnicas e tecnologias] só que fica muito caro e é a gente que tem que correr atrás disso, né? Ninguém vem aqui oferecer ou... o governo fala lá, muito bonito, só que na prática mesmo isso não existe, né? $E$ se existe, fica muito caro, né? Então, se você for querer investir hoje, você acaba não tendo o retorno disso, você não consegue, né? Se você for investir e fazer tudo mesmo [vai ter prejuízo], então é a gente mesmo que tem que correr atrás, de melhorar a produção da gente, né? Na Secretaria da Agricultura [do município] tem agrônomo [...] e ofereceu e falou que está à disposicão de qualquer produtor que quiser ir lá não paga nada, mas só que o pessoal não vai atrás disso, o pessoal já ficou meio descrente, já ficou descrente com isso, que eu acho que tem que a gente mesmo fazer, chega lá é muita dificuldade,[...] a adubação tem que ser muito grande, então vai ficar muito caro e fica inviável e acaba que ninguém vai seguir isso não, não vai aproveitar. (Produtor)

Quando se tratam de produtores familiares arrendatários, pode-se observar, através dos depoimentos, como ficam a questão da adubação e da assistência técnica,

[...] nós adubamos com esterco de granja, jogamos aí 4 - 5 mil quilos por alqueire, buscamos em Bastos, hoje ele [o adubo] está 60 reais a tonelada, o cara põe aqui pra nós, a gente espalha ele na terra, gradeia a terra de novo, faz as leras e planta, neste esterco [...] já vem o calcário tudo ali, por causa da ração que é dada pra galinha, então já vem tudo que precisa a terra, agora é sempre bom fazer uma análise da terra, né? 
Porque aí você paga o que (essa terra) precisa mais, essa análise nós fazemos na Casa da Agricultura, (de graça), quando a gente leva na UNOESTE cobra, né? Mas é barato, é importante [saber das necessidades da terra], sempre é muito importante, saber quanto você vai precisar, porque às vezes você põe uma imensidade de adubo, às vezes nem vale nada...não resolve porque você não pois o adubo certo, né? [Quem te orienta?] A gente se orienta na prática, trabalhando, uns falando, outros, têm sempre uns que sabem mais que a gente, têm mais prática, e a gente trabalhando [...] na terra você vê, né? $O$ que a gente faz, ou não fez naquela área, fez com outra coisa, então você vai encaixando o tipo da terra, se é uma terra arenosa, se é uma terra massapé, né? Então tudo dá diferença e você vai aprendendo na prática”. (Produtor)

Fica evidente, nesses relatos, a troca de experiência e de informação que ocorrem entre os produtores familiares, substituindo a necessidade de um profissional formal; isto se dá devido ao sentimento de que o vizinho ou o amigo tem mais conhecimento na prática agrícola e pela maior confiança que existe entre eles,

Eu procuro [informações técnicas] entre a gente, né? Ás vezes você procura um agrônomo pra saber alguma coisa e pela resposta dele você vê que não tem nada a ver com aquilo que você quer saber, mas ele também não fala que não sabe, um exemplo, teve um agrônomo aqui, ele apareceu há uns 8 anos vendendo adubo, próprio pra batata, ele vendeu pra todo mundo, só que foi só conversa..., não tenho assistência técnica. Quando eu fiz financiamento pelo Banco do Brasil, uns 6 anos atrás, tem um agrônomo, ele ganha até 200 reais pra fazer a vistoria eu falei: você não vai lá ver a lavoura? Ele falou: não! Eu não, eu entendo de tomate [e não de batata-doce]...você entende mais do que eu...., falou bem claro! (Produtor)

E, assim como alguns demonstram preocupação com as técnicas e assistência técnica, outros nem tanto,

Não, nunca fizemos nada, fomos deixando assim natural (árvores frutíferas) não fizemos nada de mais, nunca fomos atrás de nenhum agrônomo, nem [para] a poncã. Chamava de vez em quando, mais não vale tanto a pena porque se fizer do jeito que eles querem não há dinheiro que chegue, então a gente vai só por cima, né? [...] 0 leite eu tinha [assistência técnica], eu entregava no laticínio Santa Clara, né? Mas o preço [dava] mal e mal só pra pagar a despesa do empregado porque [o leite] era MUUUITO barato, MUUUITO barato, no começo foram...poucas vacas, 5-6 só pra consumo nosso mesmo, daí foi aumentando...no começo entregava mais pra família, aí o leite aumentou e abrimos... né? Acho que uns 12 anos vendemos para o Laticínio Santa Clara, o preço agora no ano passado [...] chegou foi 38 [centavos], agora está em 35 (Agosto/ 2001), no tempo de ter muito (leite) é até 28 [centavos].Eles falavam que tinha [assistência técnica veterinária] mas 
nunca tínhamos certo, sempre chamávamos mas não adiantava, aí eu tinha que chamar particular mesmo, eu sempre chamei particular, de Regente Feijó [cidade sede do município] eu nem conhecia então, mais fácil chamar pessoas que já estão acostumadas, que sempre vem aqui, no fim a gente mesmo se virava porque sai caro, né? Deixava remédio comprado e a gente vai levando. (Produtor)

Entretanto, outros buscam orientação de agrônomos, através da UNOESTE,

A técnica e a tecnologia que eu uso aqui é uma técnica que eu adquiri através da experiência com o Dr. Pedro da Faculdade [Agronomia da UNOESTE]. A gente procura seguir a risca não usando o agrotóxico que não é permitido para a horticultura. Se a gente ainda não produz uma agricultura orgânica, estamos bem próximos, usando o esterco de galinha, a casca do amendoim pra fertilizar a terra e usando adubo foliar, para melhorar a qualidade da folha, e a gente segue a risca desde a produção de mudas, que a gente faz aqui no local mesmo. A gente faz análise da terra, pelo menos uma vez por ano, pra ver o que falta na terra, se está faltando calcário, se está faltando adubo orgânico, se alguma composição da terra está falha, como os nutrientes que precisa para produzir as hortaliças. Isso é feito lá na Faculdade mesmo, aí eles dão a receita, né? Você tem que aplicar mais calcário, mais adubo orgânico ou algum componente. Faço as curvas de nível, curvas de contenção. (Produtor)

Após os dados gerais e o destaque de algumas declarações colhidas nas entrevistas, é possível verificar-se que os produtores conhecem e utilizam algumas técnicas e tecnologias; entretanto, quando o agrônomo ou o técnico sugere o uso de certos produtos, seja o adubo, o calcário ou agrotóxicos, o produtor se depara com custos com os quais ele não pode arcar, devido à incerteza de que no decorrer do processo produtivo, ele terá retorno daquilo que foi gasto.

Uma outra questão está relacionada com a assistência técnica e as especificidades de cada cultura agrícola. Há limitações para resolver problemas com pragas e doenças em culturas diferentes; também se verificou o número reduzido de técnicos e de agrônomos para o atendimento aos produtores, sejam eles das Casas da Agricultura ou mesmo da Cooperativa de Laticínios e de outros laticínios.

No aspecto relacionado aos equipamentos e às máquinas utilizados pelos produtores, foi possível notar, principalmente, o sucateamento e a dificuldade de muitos produtores em adquirir máquinas e tratores mais novos. 
FOTOS 7 E 8 
TABELA 27. MÁQUINAS E EQUIPAMENTOS

\begin{tabular}{|l|c|}
\hline MÁQUINAS, EQUIPAMENTOS E VEÍCULOS AUTOMOTORES & NÚMERO \\
\hline Trator & 23 \\
\hline Irrigação & 4 \\
\hline Ordenhadeira mecânica & 7 \\
\hline Carro & 18 \\
\hline Camionete e/ ou Utilitário & 9 \\
\hline Caminhão & 5 \\
\hline Moto & 4 \\
\hline Não respondeu & 15 \\
\hline
\end{tabular}

Fonte: Trabalho de Campo, 2001.

Foi possível constatar, através da “fala” do produtor, as limitações em renovar ou mesmo em adquirir máquinas e equipamentos, “A gente tem um trator e o equipamento dele: grade, tombador, carreta, roçadeira, a gente comprou há uns $\mathbf{4}$ anos, [...] usado, não tem condição [de comprar novo]. Só se vendermos o sítio, [o trator] vai quebrando e a gente vai arrumando”. (Produtor)

Assim, as máquinas e os equipamentos dificilmente são novos; os agricultores têm sempre despesas com a manutenção destes equipamentos, bem como a subutilização, devido ao desgaste das máquinas, o que se reflete na necessidade de maior tempo para realizar um determinado serviço,

As máquinas nós compramos só de $2^{\mathrm{a}}$ mão, nunca comprei máquina nova, porque é caro, né, sei lá num dá pra comprar, não...Hoje vai fazer um investimento, a gente investe isso daí para plantar e depois se [não der] e o problema nosso mesmo vou falar...Não é nem a produção, produzir a gente vai produzindo, 0 problema nosso é... o preco, $[. .$.$] o$ óleo diesel teve uma época que com um litro de leite a senhora comprava um litro de diesel, hoje precisa quase 3 litros de leite. [...] nós logo que passamos pra leite B, compramos um resfriador, é meu. (Produtor)

Embora os produtores relatem que não conseguem comprar máquinas e equipamentos novos devido ao seu preço, quando realmente necessitam adquirir algum, como no caso do resfriador para o leite (uma exigência da COOLVAP), eles fazem um esforço e compram, não sem antes contabilizar as vantagens ou as desvantagens dessa aquisição.

Trator, pulverizador, são próprios, comprados em (19) 90, aquele lá foi comprado novo [o trator], tem irrigação de 88, está boa, é motor....fizemos retífica, né? [...] só usamos quando faz seca mesmo, né? Foi financiado, esse [trator] aqui é 94, compramos usado, né?,.....[O financiamento compensou?] Aquele [trator] lá, quando compramos 
pagamos (a mais) 3 vezes o valor dele, nós compramos no Plano [Plano Collor] num preço, né? Depois estourou o juro [...] quando nós pagamos a última parcela, a ultima parcela era o valor do trator no mercado, toda vez que nós íamos pagar a prestação, comprávamos ele, nós pagamos 3 vezes, se não pagássemos....., aí tinha a propriedade hipotecada, tinha gado na hipoteca.......num tem jeito é corda no pescoço. (Produtor)

Como o produtor acima descreve, devido às oscilações econômicas, o preço final pago pelas máquinas mais novas, através do financiamento, daria para comprar mais dois tratores...,

Eu tenho, meu trator 79, pra você ter uma idéia, né? Só que eu tenho vontade de compra um novo, né? Essa semana mesmo passou um cara aqui pra vender, $34.000,00$ reais, aí juro de $8 \%$ ao ano, é tudo muito fácil, né? Mas só que aí o que adianta você investir numa máquina, se você não tem pra quem vender sua producão...não sabe o que vai acontecer lá na frente, né? Não é igual ao empresário, ele prevê... a a indústria dele lá, a produção dele pra daqui a 5-10 anos, ele sabe o que vai acontecer, a gente não sabe... Você compra um trator desse aí, 34.000,00 reais........, eu estou vendo um monte vendendo [trator] com 4-5 anos de uso pela metade do preço, agora eu vou investir $34.000,00$ reais para colocar numa atividade que eu não sei se vai dar certo, não tem nada que vai me dizer que isso vai dar certo, e....então tem que ficar com o [trator] velhinho mesmo, o (19) 79 , então a lavoura está muito sucateada, né? Por causa disso, você vai a qualquer propriedade você não acha uma máquina nova, só máquina velha. (Produtor)

A incerteza com relação ao preço que será alcançado por sua produção faz o

produtor ter muito receio de arriscar novos investimentos em máquinas e equipamentos.

Entretanto, outros, com maiores rendas, investiram em equipamentos,

[...] temos a máquina que lava, tem a correia que classifica e a carregadeira pra levar até o caminhão, e na lavoura nós temos os 2 tratores, [trator] novo nós nunca compramos, porque é muito caro e no dia de amanhã você vai vender e não tem valor nenhum, então a gente compra um velho e vai se virando com ele, né? Essas máquinas nós temos faz 7 anos, a lavagem era na mão antes, buscava a batata de trator, não tínhamos caminhão...era uma loucura...., hoje nós temos condições de soltar até duas cargas no dia, naquele tempo nós tínhamos condições de soltar, no máximo, duas cargas por semana, as máquinas são brasileiras, temos assistência; essa máquina já é a terceira porque gasta muito, usa demais, sempre, e quando não tem batata, usamos pra abóbora, tomate, pimentão.(Produtor) 
Esse produtor familiar acima, que também comercializa a batata doce descreve como pôde diminuir o tempo do processo de lavagem e do encaixotamento com uso de máquinas, assim como o escoamento da produção.

\section{A única máquina que eu tenho aqui é um micro trator Tobata, muito antigo por sinal, ele já tem 28 anos de uso e é o que eu uso aqui pra fazer os canteiros, ele é bem obsoleto, é bem antigo mas é a minha ferramenta principal, eu não posso ficar sem. Tenho também irrigação, que funciona a energia elétrica, que não é a óleo diesel [...]. (Produtor)}

A necessidade de manutenção dessas máquinas e equipamentos, como retífica e substituição de peças entre outras, movimenta oficinas e revendedores nas cidades da região; contudo, o custo dessa manutenção parece não ser calculado pelos agricultores, ou mesmo sabendo dessa despesa, eles não se arriscam em adquiri-las novas.

Um outro aspecto importante desses relatos é a questão da comercialização da produção e os rendimentos advindos dela. Como já pude observar anteriormente, esse é um fator que sempre preocupa e desagrada o agricultor familiar, pois ela é fundamental para que eles possam continuar e mesmo planejar suas atividades, bem como satisfazer as necessidades de suas famílias.

A comercialização da produção dos agricultores familiares entrevistados, conforme a tabela 28, ocorre de formas variadas. Os produtores de leite, $68 \%$ dos entrevistados, comercializam sua produção principalmente com a COOLVAP e com os laticínios da região, embora encontremos alguns que vendem leite “in natura”, isto é, sem pasteurização, diretamente aos consumidores.

Aqueles que exercem atividade agrícola comercializam sua produção de forma expressiva com intermediários ou cerealistas, perfazendo 52\% do total, enquanto aqueles que vendem a sua produção diretamente ao consumidor, representam 20\%. Dentre os produtores entrevistados, há um (1) que exporta sua produção e a de outros agricultores. 
TABELA 28. PRODUÇÃO / COMERCIALIZAÇÃO

\begin{tabular}{|l|c|c|}
\hline PRODUÇÃO */ COMERCIALIZAÇÃO & $\mathbf{N}^{\circ}$ & \% \\
\hline $\begin{array}{l}\text { Venda direta ao consumidor } \\
\text { (feira, sacolão, supermercado) }\end{array}$ & 13 & 20 \\
\hline Intermediário & 10 & 16 \\
\hline CEASA & 9 & 15 \\
\hline Exportação & 1 & 2 \\
\hline COOLVAP & 23 & 37 \\
\hline Outro Laticínio * & 20 & 32 \\
\hline Cerealista (Local) & 8 & 13 \\
\hline Cerealista - SP/RJ/PR & 5 & 8 \\
\hline Frigorífico & 7 & 12 \\
\hline
\end{tabular}

Fonte: Trabalho de Campo, 2001.

* Sete (7) produtores declararam que consomem parte do que produzem.

* Santa Clara (Pirapózinho), Líder (Stuani/ Martinópolis), Iepê, Carlucci (Álvares Machado), Tarabai, Leco, Rancharia, Vila Emília.

No caso da comercialização da produção agrícola, a venda para o intermediário é a forma de comércio principal,

Nós só vendemos para o intermediário, para cidade só algum pouquinho, muito pouco de tomate...[...] em Regente Feijó entregamos muito pouco, por exemplo, entregamos 100 caixas por semana, a senhora planta uma área grande às vezes vai tirar 300-400 caixas por semana então não há consumo, então... a gente apela para o CEASA, [leva para] comprador lá do CEASA. O problema de ter um Box, quem já tem... a gente..., eu vou falar, a gente conversa com eles e o problema é que nêgo...ó...não paga, não paga. Pra gente entregar direto lá em São Paulo num Box, hum... a senhora não conhece ninguém, não sabe quem é o comprador..., piora mais ainda, então a gente escolhe os compradores que a gente acha que é mais ou menos [bom pagador], pra vender. (Produtor)

O CEASA é uma alternativa para a venda da produção, já que lá é possível vender uma quantidade maior do que nas cidades sedes dos municípios vizinhos a Presidente Prudente, embora tenha ficado claro que os produtores gostariam de poder contar com outras formas de comercialização, bem como de poder pôr preço na sua produção. A incerteza quanto ao pagamento por parte do comprador é um outro fator que preocupa o produtor familiar, no momento da comercialização,

[...] para o intermediário [...] tudo para o intermediário, às vezes põe direto, mas é muito difícil, né? A maior parte do movimento da gente é para o intermediário. Intermediário e CEASA, né? Vamos ligando, vendo o povo que paga, né? Estamos até levando sorte, a gente cuidou 
muito, né? [...] sabe, hoje em dia, se os caras vem aqui comprar uma melancia [...] antes de carregar [...] se for com cheque... vamos consultar, e a gente consulta na hora, né? Perguntamos: $O$ senhor carregou [melancias] onde? Ah, eu carreguei de fulano de tal, temos a lista ali na camionete com tudo quanto é nome de plantador de melancia, né? Aí a gente tem contato no sul, aí tem os caras de lá que a gente liga. [Vocês já levaram prejuízo?] Já, já levamos, e os caras de lá ligam aqui também. gente já conseguiu eliminar uma boa parte...[dos intermediários desonestos] [...] se eu tiver 10 áreas de melancia para vender, eu procuro vender para 10 pessoas diferentes, porque se 2 me derem calote sobram 8 , já vendemos até 40 viagens de melancia, uma roça inteira pra 1 pessoa só, né ? Mas hoje não faço mais, as vezes o cara sofre um acidente........hoje o cara está bom [é bom pagador]. Por exemplo, nós vendemos melancia quando?... Em dezembro do ano passado [2000], né? Nós vamos vender melancia agora em novembro, outubro [2001], né? E se o cara não pagar...... [Estão satisfeitos com essa forma de comercialização?] Contente não, né? É meio difícil pra gente mesmo vender porque mercadoria nós num temos, não produzimos, para vender o ano inteiro por exemplo, então você não pode contratar lá no CEASA o ano inteiro [...] Eles estão começando agora a organizar [outras formas de comercialização] isso, né? Eles estão vendo uns negócios aí mas, está com 60 dias, né? Ainda está começando a caminhar. [Como associado] 5 reais por mês, [a Associação] está com 42 associados. [E o preço da produção?] Depende do dia, é o mercado, o preço é o intermediário que vem e fala: está tanto, porque a gente nunca dá preço nas coisas da gente, né? [E para receber?] Aí é que está o problema, às vezes 30-40-50 dias, né? Às vezes, têm muitos que dão calote, né? Os amigos que plantam, a gente [...] liga e....[ficam sabendo]. [Para onde é vendido?] Geralmente eles levam para São Paulo, para o Sul, nós vendemos muito para o Sul aqui, nosso mercado forte mesmo é para o Sul, [para o] Paraná. (Produtor)

Como é possível perceber, essa etapa é complicada, pois o produtor não confia no comprador; entretanto, há uma rede de comunicação entre eles no sentido de se protegerem contra possíveis maus pagadores.

Vendo para intermediário, para o CEASA e daí o CEASA repassa, né? Por que é uma corrente, infelizmente é isso, nosso país é isso, precisa disso, né? Porque se não tiver... tem que ter o produtor, do produtor tem que ter um que atravessa ele aqui na roca para jogar no mercado, do mercado atravessa para jogar ele no consumidor, $[. .$.$] se for querer viver$ sozinho não consegue, [...] aí se o cara vai plantar e vai vender lá na frente, não consegue... ele não consegue... continuar. (Produtor)

No caso de desabafos como do produtor acima, nota-se um sentimento de resignação e conformismo. Refletindo sobre esse posicionamento, fica evidente que quando não há uma organização social ou mesmo uma associação entre produtores, fica difícil criar uma rede que ao mesmo tempo oferecesse vantagens sociais e econômicas que os 
protegessem. E deve-se ressaltar, também, a fraca atuação do Estado e das políticas públicas existentes frente a estas questões que, caso fossem tratadas com maior seriedade, poderiam mudar a situação dos preços e da comercialização para este setor produtivo.

\begin{abstract}
Vendo, compro e exporto, e a gente compra de fora também, né? Porque com o que a gente planta não mantém os compradores que a gente tem, então mais é compra, [Nesses 15 anos, ele foi conhecendo os compradores]. Foram aparecendo. [...] Informações boas e também a gente tem que trabalhar numa boa mercadoria, né? Sempre fazendo ela ficar boa, mesmo que seja uma mercadoria ruim, mas com uma boa classificação. [Com relação à exportação?] [Para onde?] Fora daqui é o Uruguai, Argentina, Paraguai, três lugares que nós exportamos [...], né? E a França [Foi pouca, mas é um bom lugar também], eu tenho vontade de voltar (a vender para a França), os caras sempre procuram a gente mas, por causa da qualidade..., como [a muda] foi muito plantada, ela foi tendo uma qualidade muito ruim; na verdade, eles acabam pegando a nossa batata [doce] mesmo. Eles [os compradores do exterior] pegam em São Paulo, mas a batata é nossa daqui [vendida para intermediário]; não temos Box em São Paulo, vendemos para o pessoal que distribui no CEASA do Rio, em São Paulo é pouco. [Pergunto sobre os sub-produtos da batata] Nós achamos que a que sai daqui é para consumo, frita, assada; no Rio, eles fazem farinha, fazem coxinha, nhoque, doce..[...] e São Paulo tem muitos nortistas, então é a batata-doce. A batata-doce de mercado [o transporte] é caminhão nosso, do Rio e São Paulo, agora para fora [para o exterior] é carreto.(Produtor)
\end{abstract}

Mesmo para esse produtor entrevistado, que é também comprador, existe a fase de comercialização dividida com compradores intermediários.

Vendo no atacado, para o intermediário sempre, [...] sempre com pessoas conhecidas, fomos conhecendo, né? [E o preço?] Varia muito, né? Eles que mandam, você nunca manda no preco da sua mercadoria, é péssimo, né? Porque se eu tiver pouco eu mando, se tiver muito ele manda, [O que faz o preço estar melhor ou pior] A falta de mercadoria, [e a qualidade faz diferença?] Não, é só a falta, influencia pouco [a qualidade] muuito pouco, quando a batata está em falta você manda qualquer biroquinha que você vende, agora quando tem muita.... [Eles vêm buscar?] Não, eu mando pra eles, pro Rio, São Paulo, tudo CEASA, [Qual é a quantidade?] Depende... depende da época, se você pega frete, você manda um caminhão por semana, se você tiver menos, você manda menos, não tem um limite, por exemplo, um contrato com eles, antes de mandar, eu ligo... Vendo sempre pra São Paulo, Rio...tem consumo, né? (Produtor)

O intermediário, com freqüência, é quem determina o preço da produção, que variará, como sempre em economia de mercado, dependendo da oferta ou da escassez do produto. Isso demonstra a importância que ele tem na comercialização e na regulação do 
volume da produção, embora a mesma só seja possível com um planejamento mais cuidadoso da safra pelos produtores, o que, entretanto, não ocorre.

A escala de produção é outro fator que diferencia o alcance do produto no mercado e, conseqüentemente, a forma de comercialização; desta maneira, se pode observar o relato,

Nunca vendi na feira, nem pro CEASA, vendia pra intermediário, levava direto pra supermercado, só supermercado, é porque [a produção] aqui [a produção] é muito pouca não tem jeito de esparramar, né? Se começa a entregar uma coisa tem que ter responsabilidade, né? (Produtor)

Para os produtores familiares que vendem sua produção de leite para a COOLVAP ou para outros laticínios, o preço pago por litro é o centro do problema e quase sempre é o critério para a escolha daquele para o qual irão vender seu produto,

Vendo para a COOLVAP. [...] O leite tem vezes que o nêgo trabalha no prejuízo, e o lucro é muito pouco, porque se uma garrafinha d'água custa 1 real, o litro de leite até outro dia era vendida por vinte centavos, vinte e cinco....., mas agora, eu vou falar uma coisa pra senhora, o melhor leite que existe é aquele do [saco] plástico, o leite B; o leite de caixinha eles põem até formol dentro pra conservar; o leite é uma porcaria que azeda à toa, o leite de caixinha [Longa Vida] só é a Tetrapak que fabrica, né? Então ela custa 33 centavos [Mais caro que o preço pago ao produtor pelo litro de leite]. Pra nós aqui, o melhor [preço do] leite é [o da cooperativa que paga] 40 centavos mais ou menos. [...] e [...] quando o leite está em falta, aparece muito terceiro [compradores de outros laticínios da região] e oferece até mais do que a senhora está vendendo, depois que a senhora passou a entregar, passou 2 meses passou 3 eles igualam com o outro preço, ou até pior do que o da Cooperativa. Tem muita gente que mete o pau, mas a cooperativa paga, a senhora pode até gastar o dinheiro [antes] que eles pagam... (Produtor)

Conforme ouvi nas entrevistas, alguns laticínios, dependendo da época do ano, oferecem um preço melhor por litro de leite, mas, conforme a época do ano e o volume da oferta de leite eles diminuem o preço sem avisar ou, às vezes, nem chegam a pagar em dia.

Assim, os produtores sempre vão atrás de preço e da segurança, submetendo-se a receber menos por litro de leite em um laticínio que, pelo menos, pague em dia.

Para se exercer uma atividade econômica é preciso dinheiro; dessa maneira, o produtor familiar, para desenvolver seu trabalho, seja ele produtor agrícola ou mesmo ligado 
à produção pecuária, pode precisar de recursos financeiros devido às características de cada cultura ou de cada atividade escolhida.

Desta forma, muitas vezes, da possibilidade de acesso as formas de financiamento da produção, seja ele público ou privado, poderá depender a continuidade ou não dos produtores na atividade agropecuária. Vejamos, então, a seguir, a opinião dos entrevistados.

TABELA 29. FINANCIAMENTO DA PRODUÇÃO

\begin{tabular}{|l|c|c|}
\hline $\begin{array}{l}\text { REALIZOU FINANCIAMENTOS* NOS } \\
\text { ÚLTIMOS 5 ANOS? }\end{array}$ & $\mathbf{N}^{\circ}$ & $\%$ \\
\hline Sim & 28 & $44 \%$ \\
\hline Não & 15 & $24 \%$ \\
\hline Não respondeu & 20 & $32 \%$ \\
\hline
\end{tabular}

Fonte: Trabalho de Campo, 2001

* PRONAF (6 produtores), Banespa - Santander, Banco do Brasil, Caixa

Econômica Estadual.

Os produtores reconhecem que o financiamento tem dois lados: um, que os possibilita obter recursos para dinamizar a atividade agropecuária; e, outro que pode torná-los reféns do banco que exige mais e mais garantias deles.

O financiamento nunca é bom, né? Mas eu acho que o problema do financiamento tem muita burocracia pra gente fazer, mas a gente ainda consegue fazer por que a gente sempre pagou certinho o banco, né? Tem crédito, e não vou falar que o juro do banco está comendo o agricultor pela perna que nem nêgo fala não, não é, é um jurinho, não é baratinho, mas também não é de espantar, o duro nosso é.... na medida que a senhora colhe a lavoura $e$ [depois] pra vender [...]. Porque se tivesse preço a lavoura....e o que o governo quer é isso mesmo, [...] ele faz a cesta básica em cima de nós, dar comida pro povo aí... [o governo] não quer trabalhar essas coisas, né? $\mathbf{E}$ não sabe quanto custa [para produzir]. [...] mas que eu vou falar para senhora, que não é fácil, e aqui todo mundo trabalha, as mulheres ajudam..., o juro do PRONAF é 4,5 ao ano não significa nada, num é um negócio ruim, o problema nosso só é o preço do produto, por que produzir nós produzimos. (Produtor)

E, mesmo se sujeitando às garantias exigidas pelos bancos, o produtor não terá a segurança de que o volume e o preço alcançados por sua safra poderão quitar o empréstimo tomado por ele.

Nós já fizemos financiamento, mas ultimamente não, está com uns 2-3 anos, né?[...] Trabalhamos com o Banespa, depois com o Banco do 
Brasil, de Regente [Feijó]. Foi para melancia, pra feijão. [Em que ano foi?] [...] 1999 para trás, sempre demos conta, teve época que não deu não, o que perdemos, nós renegociamos, prolongamos a dívida. [Fazem seguro?] Tinha de primeiro, agora não tem mais, né? Para melancia num tem mais [Para outras coisas tem?] Só tem pra feijão, né? Só COGESP faz [para] feijão e milho né? pra tomate faz também, né? [ $\mathrm{E}$ o PRONAF, já usaram?] Meu pai usou, né? [Vocês acham que esses financiamentos ajudam?] [...] $\mathbf{O}$ problema do financiamento é a burocracia que é grande, né? Você vai fazer um financiamento e... eles pedem tudo..., quem faz é o Banco do Brasil, e o Banco do Brasil é uma burocracia violenta, e geralmente quando você vai pedir o financiamento você tem que estar zerado, limpinho, sem [dever] nada, né? Se tiver alguma coisa pendente já não sai, então ás vezes você tem um pouco de dinheiro, acaba sendo muito melhor você pagar $3 \%$ lá na firma [financiadora], do que ficar aí... 60 dias aí pra pegar o financiamento, você tem que pegar o ITR do proprietário, pra trás 5 anos do ITR dele, né? [Esses produtores são três irmãos. Eu pergunto: qual de vocês faz essa parte?] Ele cuida da roça, ele cuida de Banco, eu mais na parte de venda, no fim cada um dá uma mão né? Dá uma ajuda, dá idéia, divide um pouco pra não ficar tudo..[decidido por um só]. Realmente, cada um pega uma coisa, tem conhecimento num lugar e outro no outro, né?. (Produtor)

Desta forma, muitos dos entrevistados têm evitado tomar empréstimos bancários, sejam eles de bancos públicos ou privados.

Alguns relataram que nunca utilizaram tal opção, devido à burocracia exigida e pelo tempo e custos despendidos antes mesmo de obterem o dinheiro pedido.

Não fiz. Já fui até perguntar, e me informar no Banco do Brasil, daí você chega lá, ah... não, nós não estamos financiando feijão, né? Você tem que ir lá em Machado, aí chega lá em [Álvares] Machado é aquela burocracia, tem que arrumar isso, tem que arrumar aquilo, tem que pagar seguro, tem que pagar um agrônomo, você paga $2 \%$ do seu projeto já, o agrônomo só vem aqui uma vez, aí ah... mas tem seguro, só que seguro só cobre vendaval, granizo, quer dizer... sol não cobre... então, quer dizer você não tem segurança nenhuma, né?, é... aquela burocracia toda... então, eu acho que não funciona, e outra você não tem garantia se você vai vender sua produção, né? [...] Então dá medo, é melhor você plantar menos e plantar com recurso próprio, porque o governo até que passa isso [de ajudar o produtor] [...] que é muito bonito. A semana passada um colega estava me falando que o governo solta financiamento, $[. .$.$] mas o banco.... não dá, não dá porque o juro é muito$ barato, um juro de $8 \%$ ao ano, então o banco não tem é.... interesse em emprestar um juro tão barato, então, né? $O$ governo acha que o dinheiro veio, acha que o dinheiro foi emprestado, eles [os bancos] fazem as manobras deles lá e passam como que o dinheiro foi emprestado e aí direcionam isso a 1-2 que vai ......e acaba que visando o interesse do próprio banqueiro então, é parente dele, né? [...] Infelizmente, o Brasil é isso, essa corrupção que você está vendo [...] agora, o problema esta no 
pequeno, o pequeno está lascado pra sobreviver, tem que fazer isso que eu estou te falando, por si mesmo, não tem financiamento, não tem incentivo, não tem nada, essas coisas que vem [são] muito burocráticas, né? A pessoa normalmente já é desinformada, chega lá é aquela burocracia, o cara não consegue atingir...[...] tinha que ter mais facilidade ao acesso, né? [...] Eu não tenho nada contra os sem-terra,... mas você pega o sem-terra... [o governo] dá a terra pro cara, o cara vem não sei da onde, não tem nada no nome dele, ele vai e financia e dá $50 \%$ de desconto pro cara, juro de $6 \%$, ele faz tudo para o sem-terra, né? Agora para o pequeno ele não faz, agora o cara que está lá com a família, está plantando 5 alqueires de terra, ele nuão financia o cara, num tem como, num tem jeito de você trabalhar, né? ...[e o PRONAF? Você conhece?] Já fui também ver, mas...., [...] Já começa aquela burocracia danada, [...] é muito pouco dinheiro, né? Solta 5000 reais, o que você vai fazer com 5000 reais? Não consegue fazer nada, né? Se pega não tem como pagar [...] então melhor não pegar, né? [...]. (Produtor)

Outro fator do desinteresse em fazer financiamento é a percepção de que os bancos não têm interesse em fazer empréstimos a produtores que investirão em áreas pequenas e correrão os mesmos riscos que aqueles que investirão em áreas maiores, os quais terão mais chances de honrar suas dívidas, ao oferecerem mais garantias.

As linhas de financiamento do PRONAF parecem não agradar aos produtores entrevistados, pelo baixo valor que as mesmas oferecem e, também, pela falta de informação, aliada a uma resistência em se organizarem em associações e cooperativas, que poderiam facilitar a obtenção de maiores empréstimos.

[...] nunca precisamos fazer financiamento, usamos o dinheiro nosso mesmo e aí fomos aumentando....[E o PRONAF?] Não..., nunca, [E se você precisar?] Seria bom se houvesse....essas coisas aí são muito difíceis, exigem muita coisa, [...] precisa da [outra] pessoa pra avalizar, [...] no dia de amanhã ele chega [...], (você pediu pra ele avalizar, por exemplo, 5 mil reais), e manda você avalizar 100 mil reais, você é obrigado a avalizar pra ele porque ele já avalizou pra você, então é uma coisa que se torna muito difícil, né? Então é melhor, é mais fácil, se for pra você tocar uma lavoura, vamos supor, uma lavoura com 30-40 alqueires no Banco, você toca uma com 10, e com seu recurso mesmo, se vira, e hoje entrar no Banco principalmente pra financiamento, é muito difícil, ixi... é difícil demais. (Produtor)

Outros produtores entrevistados, contudo, frente a essas dificuldades, preferem diminuir a área plantada a tomar empréstimos bancários,

Não, não faço sempre não, só um pra plantar batata, custeio, né?[No que usou o dinheiro?] Pra pagar a renda, comprei adubo, comprei calcário. [Em conjunto com outros proprietários?] Comprei sozinho, geralmente [o 
prazo] é 30 dias, eles têm um plano safra aí, mas é de 3 meses, para a batata não vale nada..., um juro violento [...] [e o PRONAF, já ouviu falar?] Já ouvi falar, sim, mas eu não fiz, esse um que eu fiz [foi] com recursos meus, ele se afina com o PRONAF, inclusive eu fui providenciar pra fazer o PRONAF, que eu queria...12.000, o que eu fiz, esse é uma linha difícil [Banco do Brasil] 8,5 \% [de juro a.a], eu só consegui com conhecimento [avalista], o PRONAF é 5\%. Esse ano eu fui fazer o PRONAF, ver se eu conseguia, porque é mais fácil, é menos burocracia, aí a moça [do Banco] falou: você não se encaixa mais no PRONAF, por que você já fez noutra linha, mas eu não queria tirar $12.000 \ldots$... então eu não consegui tirar, eu queria 5000 e 0 juro era mais barato, $5 \%$, o outro de 12.000 é 8,5\%. (Produtor)

Há aqueles também que já tiveram experiências familiares passadas, nas quais houve a necessidade de vender parte do que possuíam para quitar dívidas contraídas com o banco,

[...] meu pai fez, inclusive quando ele vendeu o sítio...ele desanimou porque ele fez um financiamento pra plantar abobrinha e teve que praticamente vender boa parte dos bens que ele tinha para pagar esse financiamento. Então, a gente já tem uma certa experiência, que os juros são altos, os encargos são muito altos e a gente não tem coragem de chegar no banco e pedir financiamento, é claro que faz falta, né? Eu, pra começar aqui neste arrendamento [...] eu peguei com um amigo 400 reais pra comprar o $1^{\circ}$ adubo, a $1^{\circ}$ semente, a $1^{a}$ remessa de bandejas pra plantar, a $1^{\mathrm{a}}$ tonelada de esterco de galinha e assim por diante; 400 reais foi o meu início pra começar a atividade, e pago o juro até hoje e não consegui pagar... depois de 4 meses. [Conhece o PRONAF ?] Não conheço, vejo falar no rádio mais não tenho assim os detalhes, pormenores, né? Como funciona e que finalidade tem não sei... (Produtor)

É possível enxergar, após este destaque, as enormes dificuldades enfrentadas pelos produtores familiares frente ao sistema de financiamento disponível para a agricultura e a pouca importância desse grupo para um sistema financeiro que privilegia somente o lucro e a especulação, não levando em conta as especificidades desse grupo produtivo.

Embora reconheça que os produtores familiares, ao não se organizarem, enquanto grupo social, têm uma parcela de culpa, pois não têm força de reivindicação por melhores condições para obter financiamento, ao mesmo tempo as políticas públicas para a agricultura familiar, apesar dos esforços feitos até aqui, não têm conseguido, ainda, apontar caminhos que contribuíssem para mudanças neste aspecto.

Nesta pesquisa, elegi como princípios definidores o conceito de agricultor familiar como sendo aquele em que o trabalho, a terra e a família estão intimamente 
relacionados; desta forma, ao tratar a questão da mão-de-obra das unidades familiares, esclareco que, como disse esse produtor: “[...] aqui todo mundo trabalha, as mulheres ajudam.....” (Produtor), a(s) família(s) está(ão) intimamente ligadas ao trabalho agrícola, com uma divisão de tarefas entre os membros. Cabe ressaltar que os produtores familiares entrevistados neste trabalho são agricultores que produzem para o mercado; do total, somente 11\% deles revelaram produzir algum produto para consumo próprio.

Contudo, apesar de contarem, basicamente, com a mão-de-obra familiar, devido ao calendário agrícola, à extensão das áreas cultivadas e às etapas da produção, a necessidade de contratação de mão-de-obra fora da família, conforme ficou demonstrado, tem se tornado muito comum. Na seqüência, tratarei das relações de trabalho entre os produtores rurais entrevistados.

Segundo os produtores declararam, 34\% só contam com mão-de-obra família; 38\% têm de 1 a 5 empregados fixos; 19\% declararam ter empregados temporários e, 9\%, contratam diaristas. Como se pode verificar nos relatos, as questões trabalhistas são as principais preocupações dos produtores, o que os leva a adotar práticas e estratégias diversas de contratação da mão-de-obra.

\section{TABELA 30. MÃO DE OBRA DAS UNIDADES FAMILIARES}

\begin{tabular}{|l|c|c|}
\hline TIPO & NÚMERO & \% \\
\hline Só Familiar & 21 & 34 \\
\hline 1-5 Empregados Fixos & 24 & 38 \\
\hline Temporários & 12 & 19 \\
\hline Diaristas & 6 & 9 \\
\hline TOTAL & $\mathbf{6 3}$ & $\mathbf{1 0 0}$ \\
\hline
\end{tabular}

Fonte: Trabalho de Campo, 2001.

Como já assinalado anteriormente, o número de mão-de-obra empregada nas lavouras dependerá das especificidades e da área plantada de cada cultura. Essa mão-de-obra empregada é, na maioria dos casos, sazonal e temporária.

Nós trabalhamos com gente direto, [...] empregado, bóia-fria, por exemplo, [durante] 4-5-6 meses, $[. .$.$] às vezes tem nêgo que trabalha 90$ dias e depois chama a senhora no departamento [do trabalho] e hoje a facada é grande com esse negócio, porque a juíza não quer nem saber, [...] a gente não tem condicão de registrar, e se não registrar você já viu, corre esse risco, porque se ele chamar a gente no departamento [do 
trabalho] você precisa vender o sítio pra pagar. A gente conhece o pessoal, [...] a gente pega o caminhão aí e buscamos, pega às sete e larga às cinco, com hora de almoço, de segunda a sábado, né? Às vezes a gente no sábado vai mexer com outras coisas, né? Talvez a gente dispense eles, né? Mas é.... a semana inteira.. [Quantas pessoas são mais ou menos?] No ano passado (2000) nós mexemos com uns 40 alqueires de lavoura, entre milho, algodão, feijão, café, nós tínhamos 4 peões trabalhando direto e nós somos mais em 4, 8 [ao todo], agora, na colheita então, por exemplo na colheita do algodão tinha mais de 100 pessoas na roça, mas aí é negócio de 15-20 dias né? Para capinar e fazer muito serviçinho é por dia, agora para colheita é tudo por empreita, algodão é por tanto por arroba, então... para arrancar é por metro.... lá na cidade ele trabalha no banco ele só vai fazer aquilo, se é professor só vai fazer aquilo, então sabe no sítio não, hoje está carpindo café, amanhã está carpindo tomate, depois de amanhã talvez esteja roçando feijão. (Produtor)

Os agricultores procuram se garantir de eventuais problemas, contratando pessoas “conhecidas”, isto é, aquelas que residem nas pequenas cidades e nas vilas próximas à área rural.

[Contrata empregados?] Para colheita, né? [Quantos nessa área de 20 hectares?] Mais ou menos uns 5, pra plantar, depois ficam 5 pra molhar, 5 trabalhando na área, pra colher aí precisa mais gente, conforme aperta, né? Precisa umas 15 pessoas, né? [...] hoje mesmo, precisamos de uns 3 a mais, de Anhumas, a gente mesmo conhece, eu tenho conhecimento [um dos irmãos], tem um rapaz que trabalha conosco mais tempo que tem telefone, daí a gente liga lá e já combina né, a gente fala: arruma mais amanhã. [Já tiveram problemas trabalhistas ?] Não, isso não, porque geralmente eles trabalham pouco tempo, 10 dias, 5 dias, não trabalham muito, já para.......a gente dispensar né? Então não trabalham muito tempo, né? Meu primo toca roça, volta e meia nós trocamos, faz um rodízio, não fica muito tempo [com o mesmo empregado], porque se trabalhar muito [tempo] tem problema. Anhumas não está tendo desses problemas. [...] Se o cara levar o patrão no departamento, os outros ficam sabendo já queima ele, ao mesmo tempo, a gente precisa dessa mão de obra também, é uma coisa que a gente tem que conversar, né? Tem que correr esse risco também, né? Mas a gente procura sempre trabalhar também mais na parte de amigo, né ? [Sobre as horas de trabalho] Têm dias que trabalham um pouco mais tarde, né? [Como vocês pagam?] Por dia, agora estamos pagando 10 reais o dia. Se ele trabalhar até 3-4 horas eu pago o dia, né? (Produtor)

Entre as estratégias, conforme neste depoimento, para que o trabalhador agrícola não permaneça muito tempo trabalhando para um único agricultor, há um "rodízio” deste trabalhador, estabelecido com vizinhos ou com parentes.

A gente pega [...] o bóia-fria, né? [...] na época do meu pai, a gente tinha, dentro da propriedade, 1-2 famílias que moravam, trabalhavam... 
quando precisava, trabalhavam na roça do meu pai [...] e tinha o salário dele e junto tinha um pedacinho de terra pra ele morar, criar um porco, uma galinha. Aí, veio o sindicato e começou a dar poderes a esse povo, aí o que aconteceu, o cara começou a tomar, né? $O$ cara morava na casa $e$ ia sair e já tomava a casa do patrão, por que ele tinha direito, ele estava ali dentro, né? Então, já acabou isso aí, mas agora o governo com essa lei nova da previdência também .....equiparou a cidade com o campo, né? $O$ cara tem os mesmos direitos, [...] ele trabalha 1-2 meses, aí quando ele sai, ele vai atrás dos direitos, você começa a fazer acerto pra um, acerto pra outro. Eu tive um caso de uma pessoa que trabalhou pra mim 1 ano, ele foi lá na justiça do trabalho, e falou que trabalhava há 3 anos [...] eu não consegui provar o contrário, vou ter que pagar 2 anos para 0 cara, [...] ele trabalhava pra mim 2-3 dias por semana, passava...., num dia igual hoje [estava chovendo], eu não estou trabalhando, ninguém está trabalhando....porque está chovendo, amanhã ninguém vai estar trabalhando porque tem sol, né? Você tem as épocas certas pra trabalhar, né? $O$ cara foi lá e o juiz deu como se ele trabalhasse todo dia, o ano inteiro, sábado, domingo, deu descanso semanal remunerado pra ele, sendo que ele trabalhava $2-3$ dias pra mim, né? [...] como que você vai conseguir trabalhar com gente, né? [...] esse [tipo de ] serviço eu encaro ele como um bico né? Ele trabalha o dia que ele quer, se ele não quiser vir amanhã, ele nem me comunica, $[\ldots .$.$] a previdência devia fazer o$ seguinte, fazer o cara pagar como diarista ou bóia-fria, ele ser autônomo, ele recolher a previdência dele, ou o patrão recolher os dias que ele trabalha, o cara tem uma carteirinha, ele vem trabalhar pra você, ele trabalhou 2-3 dias, você anota e no final do mês você vai lá e recolhe do fulano, sicrano e beltrano, mas....como você vai registrar uma pessoa dessa, e a justiça não quer saber, né? [...] vou ter que pagar..... deu 18.000 na conta do advogado dele, porque o advogado dele falou que ele trabalhava... das 6 horas da manhã até 8 horas da noite, né? [...] ele foi inventando, né? Ganhava 15 reais por dia.... (Produtor)

Se, por um lado, percebe-se a exploração do trabalhador assalariado pelo agricultor - contratante ao não lhe garantir direitos trabalhistas mais amplos, há também alguns abusos por parte de trabalhadores contratados que, muitas vezes, inventam dias e horas de serviço, ou não têm compromisso, como no caso relatado acima, aumentando, assim, a desconfiança do agricultor.

A legislação trabalhista, ao dar aos trabalhadores rurais direitos iguais aos dos trabalhadores urbanos, deixa de reconhecer as especificidades do trabalho agrícola e leva o empregador a fazer manobras para não ter que registrar esses trabalhadores, que ficam, assim, tão desprotegidos quanto antes.

Outros ainda preferem estabelecer uma relação de parceria ou meação na plantação, favorecendo o agricultor familiar, que é proprietário da terra ou arrendatário, de 
duas maneiras, ou seja, não ter encargos trabalhistas e um maior empenho do parceiro no cuidado com a roça, como pode-se verificar no relato que se segue,

[...] nós estamos trabalhando diferente. [...] $O$ [empregado] que está aqui trabalha todo dia; então, [ele] é registrado também, nós estamos com 5 [empregados] registrados [que trabalham no barracão onde é lavada e selecionada a batata doce]. [...] Na roça a gente prepara a terra, entrega enlerado e dá para as pessoas plantarem de a meias, na produção a gente já fixa a mercadoria também, porque fica a parte da gente e da parte do outro, que a gente também compra....., eles acabam vendendo pra gente mesmo, né? Essas pessoas já são fregueses da gente mesmo, são tudo daqui da região, vizinhos, do Montalvão, do 18, do Timburi [bairros rurais próximos], na verdade acaba sendo associação [informal] geral. Já tivemos problemas com empregado, mas daqui da barraca mesmo, mais isso daí é coisa que tem..... aí não volta...por isso até que a gente num toca roca sem o sócio, no caso os meeiros, né ? Acaba sendo melhor porque não precisa bóia fria, nós achamos que desse jeito pra nós sai melhor, né? Porque nós vamos ter a mercadoria..., a pessoa vai ter outro interesse [...], ele vai pegar e... correr atrás do serviço, vai tirar rama, vai plantar, e aí, se eu tenho 20-30 alqueires, no caso assim, e 2 de ameia quando chove, aquele um vai plantar o cantinho dele, outro vai plantar, outro vai plantar, quando pensar que não, já estou com a terra toda plantada. É a família (do meeiro) já unida (que trabalha) também que vai, né? E ali, se eles querem pôr alguém é por conta deles, eles põem, já pegam (a terra) da gente porque já não conseguem tocar ali sozinhos. $O$ ruim da roça é investir no arrendo, porque você tem que ter o dinheiro pro arrendo logo no começo e você não tem nenhuma colheita.... então se torna difícil pra eles também, né? Assim fica fácil pra gente e pra eles, por que a gente entra com a metade do custo e eles entram com a outra metade, agora os que pegam a leira pronta pra plantar, não tem trator, mas conseguem plantar, carpir, colher, né? (Produtor)

Entretanto, predomina a informalidade nas relações de trabalho, mesmo que o agricultor corra riscos ao não registrar o empregado.

Eu tenho 2, né? Trabalham sempre pra mim, não são registrados, tenho muito medo, eles eram registrados, mais eu pagava 60 reais cada um por mês, e... para o estado ficar roubando da gente, então eu procurei pegar 2 pessoas que toda vida trabalharam pra mim, pessoas que eu considero muito, eu acho que não vão me dar problema, né? Agora...é arriscado, 0 resto é bóia fria, né? [...] só plantamos quando tem chuva, 10 reais (a diária), 8 horas por dia de servico, pára na hora do almoco..., pago no final de semana. Hoje eu estou gastando 25 dias pra plantar 1 alqueire, mas já gastei 45 [...] porque às vezes você pega uma terra difícil para plantar, [...] nesses 25 dias estão incluídos plantar e tirar rama (tirar as pontas dos brotos da batata); às vezes está muito difícil pra tirar a muda, que é tirada de outra rama e levada para outra roça; então, uma média entre tirar e plantar, são 25 (dias) por alqueire, até hoje, plantei no máximo 20 alqueires e, no mínimo 10 alqueires, agora eu estou com 
um sócio e quero plantar mais, 50 alqueires. Para plantar eu emprego mais ou menos 45 pessoas. (Produtor)

O agricultor familiar que também retira leite de seu rebanho para comercializar, dependendo do tipo de ordenha (manual ou mecânica) e do número de cabeças, necessita, às vezes, de contratar mão-de-obra assalariada permanente.

Esse empregado que, na maior parte dos casos, reside na unidade de produção, não só ajuda na ordenha como pode realizar outros serviços,

Temos um que é fixo, assalariado, ele é retireiro [faz a ordenha das vacas], né? Porque como tem o leite... para tirar o leite [precisa ser permanente] e cuidar do pasto, roçar o que tem..., carpir o pomar; às vezes põe algum [outro diarista] assim, quando vemos que ele num vence [não dá conta do serviço] põe algum por dia, diarista, né? (Produtor)

No universo pesquisado, ficou clara a necessidade de haver mais braços para o trabalho na unidade de produção, seja porque o número de filhos ou de pessoas da família tenha diminuído, ou porque eles trabalham na área urbana, ou devido ao aumento da área produzida, ou pelo aumento mesmo do trabalho em geral, pois diversos produtores são agricultores e produtores de leite, simultaneamente.

Assim, as cidades e vilas próximas às propriedades representam uma reserva de mão-de-obra para os agricultores, e para os trabalhadores rurais, sejam eles diaristas ou empregados temporários, uma possibilidade de obterem uma renda, mesmo que, nesse tipo de trabalho, o tempo de contrato seja curto, sazonal e sem garantias trabalhistas.

[...] quando a gente planta bastante coisa, daí a gente pegar por dia, [...] em Regente [Feijó] mesmo, ou às vezes pegamos no sítio [vizinhos], algum conhecido, né? A gente vai atrás porque é pertinho, a gente conhece e chama, pagamos o que corre na região, 10 reais o dia, assim a gente pega mais o pessoal na época de plantar e talvez algum dia pra colher, eu também trabalho, o que mais trabalha sou eu. $O$ que eu puder economizar eu economizo (porque faz o trabalho de muitos). Contrato no máximo de 1 a 2 empregados; às vezes, dependendo da coisa que for plantar, daí usa mais, nunca tive problema [trabalhista]. (Produtor)

Contrato diaristas, eu tenho aqui 2 ou 3 diaristas constantemente, não são fixos, são pra serviços gerais: plantar mudas no canteiro, colher, fazer manutencão nos encanamentos, irrigar a horta, enfim serviços gerais... Problemas com empregados ainda não tivemos, mas corro o risco, a gente corre o risco porque vários amigos nossos enfrentaram esses problemas [...]. (Produtor) 
As organizações ou representações sociais devem ter, através de seus membros, tanto um papel de reivindicações políticas como econômicas e sociais, pois, na economia capitalista, o mercado exerce forças que penalizam, os produtores agropecuários, principalmente aqueles que fazem parte do grupo estudado nesta pesquisa.

Dessa maneira, o envolvimento ou não dos produtores entrevistados em organizações sociais, como associações, cooperativas, sindicatos, etc, podem revelar como eles têm se envolvido, enquanto grupo, na tentativa de buscar soluções para as pressões que surgem, sejam elas de que ordens forem.

Dentre os entrevistados, 16 (dezesseis) revelaram não participar de nenhuma forma de organização social; já 22 (vinte e dois) produtores rurais participam de associações, embora a maior parte deles tenham se associado recentemente e muitas delas estavam se formando, quando da realização do trabalho de campo (dezembro de 2000 a setembro de 2001); 14 (quatorze) fazem parte de Cooperativa e 9 (nove) participam, simultaneamente, de Associação e de Cooperativa; 11 (onze) fazem parte do Sindicato Rural (patronal) e 2 (dois) participam do Conselho de Desenvolvimento Rural de seus municípios.

TABELA 31. FORMAS DE ORGANIZAÇÃO DOS PRODUTORES FAMILIARES

\begin{tabular}{|l|c|c|}
\hline FORMAS DE ORGANIZAÇÃO DOS & NÚMERO & \% \\
PRODUTORES FAMILIARES & 22 & 35 \\
\hline Associação* & 14 & 22 \\
\hline Cooperativa & 11 & 17 \\
\hline Sindicato Rural & 16 & 26 \\
\hline Não participa & $\mathbf{6 3}$ & $\mathbf{1 0 0 \%}$ \\
\hline TOTAL & & \\
\hline
\end{tabular}

Fonte: Trabalho de Campo, 2001.

* Alguns produtores participam simultaneamente de Associações e Cooperativas.

Da Cooperativa [COOLVAP] a gente nem.... pode falar nada, porque... a gente não precisa não, por exemplo, precisa assim pra entregar o leite, né? $O$ remédio... o preço de lá é que nem nos outros lugares, [...] porque nunca cheguei lá e falar que eu precisei daquilo e me negaram, eu acho que pra mim...é indiferente. [Sobre reuniões com produtores] Eles nem fazem mais lá, antigamente, toda semana, cada 15 dias, tinha uma reunião, tinha isso, aquilo outro, acabou isso tudo, se eles fazem, eles fazem entre eles, só o conselho...nós aqui não somos convidados para nada. [...] Tem muita gente que mete o pau, mas a cooperativa paga, a senhora pode até gastar o dinheiro [antes] que eles pagam... (Produtor) 
Meu pai é associado na Cooperativa [COOLVAP] de leite, né? Nós [também] fazemos parte da Associação, em Anhumas, começamos a montar agora (junho de 2001), faz uns 60 dias... pra mim, nós não fomos criados para Associação não... nós não fomos criados assim. Esse povo que vem de outro país, né? Da Europa, esse povo já foi criado com uma mentalidade, que nem no sul, essa mistura de raças..., tem outra cabeça. [Por que?] Uns que não concordam, outros que aproveitam, Associação tem que ser um negócio sério, né? Na Cooperativa [de laticínio] o povo se acomodou, ninguém tira eles de lá, está do jeito que eles querem [sobre a diretoria da COOLVAP], o produtor não liga... o associado não liga... então, eles vão deitando e rolando, o problema da Cooperativa é assim..., a maior parte ali é de produtor de 100 litros pra baixo, eu participei muito de reunião ali, né? A grande porcentagem é pequeno [produtor], então, aqueles grandes [que tiram mais de 100 litros/dia] manipulam, trazem, vamos supor... na barra da saia...,né? $E$ os pequenos vão atrás, né? Não tem voz ativa, né? Os caras vão e tiram 50 litro de leite.., e eu vou perder o que vai lá, né?.... [Vocês tem resfriador?] Não, por enquanto não, [a Cooperativa deu prazo até dezembro de 2000 para os produtores substituírem os latões] porque quem tira 50 litros... num tem condições né? Não dá para pagar o resfriador, né? Acho que nós mesmos se continuarmos.... e precisarmos ter um resfriador... nós vamos ter que parar aqui, né? Ou aumenta ou larga, para aumentar é difícil, né? $\underline{A}$ gente num vê futuro no leite, para investir no leite.... (Produtor)

Pode-se notar que, a exemplo dos depoimentos citados, o fato de os produtores fazerem parte da cooperativa não indica que eles participem efetivamente das decisões ali tomadas. E, um dos motivos destacados está relacionado ao volume de leite entregue, que é pequeno; assim, as decisões e mudanças, sejam administrativas ou organizacionais, seriam tomadas, principalmente, pelos membros do conselho, que coincidentemente, entregam volumes maiores de leite.

Eu acho que em algumas regiões [Cooperativas e Associações] funciona, o pessoal tem uma mentalidade de quem já convive entre si então acaba que dando certo, mas na nossa região não funciona, já estão tentando fazer e colocar uma Cooperativa, mas eu acho que [aqui] não funciona não, porque o pessoal já acostumou a tomar cabeçada e faz essas coisas aí e vem com promessa, né? Na hora que troca o prefeito aí já muda tudo de novo então é cada um pra si mesmo e cada um vai atrás de buscar alternativas e acha o que é melhor, então por experiência.... Eu nunca fiz parte. Eu vejo na televisão, [...], mas eu acho também que só passa uma parte boa, eles pegam uma parte boa lá e mostram; então, até que fica uma coisa bonita mas eu acho que até chegar a isso eu acho que tem muita dificuldade, então sei lá..., eu acho que acaba não compensando. (Produtor)

Aqui está expressa a postura de alguns produtores que não acreditam que fazer parte de associação ou de cooperativa possa trazer qualquer mudança na realidade vivida 
por eles. A meu ver, a formação de uma organização social ou de representação deve ter cada associado como sujeito das diversas decisões que serão tomadas em conjunto, então quando o produtor acredita que propostas e planos têm que partir da administração pública isso se torna realmente difícil!

Essa Associação surgiu aí agora, mas... é [...] [ligada a Prefeitura - Patrulha Agrícola] para ter um trator na roça trabalhando, já tem o trator, né? Mas é pra ajudar também outras pessoas, tem as reuniões pra saber como estão indo as coisas, cada determinado tempo eles marcam as reuniões para... falar, discutir os problemas, né? Eles [o pessoal ligado à Prefeitura] estão muito empenhados, disseram que vão trazer agrônomos, que vão trazer... assim, facilidade para comprar um adubo, comprar um veneno.... [a contribuição é] 30 reais semestrais eu acho que tem uns 50 [membros], às vezes fazemos [as reuniões] aqui em casa ou fazem ali em Montalvão, já tem um rapaz [presidente], ele e a esposa se encarregam, o meu irmão é o secretário, tem conselheiro...tem tudo isso aí. É uma boa [o fato de ter se formado essa associação] mas tem que ter união, né? [...] o pessoal anda muito desunido, um puxa para um lado, outro puxa para o outro, a gente ainda está trabalhando em cima disso pra ver se tem mais união, é...porque não vale nada um só falar vamos fazer, se os outros num ajudarem, não tem nem como aparecer uma verba de fora, ou uma coisa assim né? Porque se não fizer aquele mutirão de ser unido não tem como aparecer [mudanças], né? A iniciativa da Associação foi da Casa da Agricultura. (Produtor)

Já nesse destaque é possível notar que a organização em associações é vista como algo que pode levar a mudanças efetivas; contudo, a necessidade de serem unidos e pensarem coletivamente nas melhorias e na tomada de decisão é fundamental. Por outro lado, observa-se, ainda, que a iniciativa de se formar uma associação, conforme o relatado, partiu da administração municipal.

Faço parte do Sindicato Rural, agora a Associação..., está se formando ainda, eu acredito que se for uma coisa séria...[...] aqui é muito difícil, um tenta comer o outro, você entendeu? Se eu entrego no lugar que você entrega, eu sempre ponho 10 centavos mais barato, para eu poder entrar, depois que eu entrei... daí é diferente, né? Então, se você entrega num lugar... eu não consigo entregar. Nós não somos unidos, mas se funcionar direito [a Associação] vai ajudar, [O que precisa para funcionar direito?] Eu acho que menos pessoas, com mais responsabilidade, eu acho que se fossem umas pessoas de fora [...], estou com vontade de participar...(Produtor)

É interessante perceber nos depoimentos que a presença de pessoas que são de "fora" é considerado como condição para o bom funcionamento da associação. A expressão “de fora” é entendida como aquele pessoal ligado à administração burocrática, 
técnica e econômica, que evita a formação de grupos locais ou a participação de políticos, que poderiam se favorecer, ao fazerem parte desse quadro.

Só [faço parte] do Sindicato [rural] de onde eu faço a [...] folha de pagamento do empregado e compro os remédios, na Cooperativa Mista em Prudente. Não, nunca participamos de nenhuma reunião, sempre vem convite mas... nós nunca fomos. Eu não entendo nada, porque eu vou, se eu não resolvo nada, então não participo, [...], mas se quando a gente falasse alguma coisa resolvesse, era bom, né?[...] Que nem calcário, eu pedi, mas você tem que buscar em Marilia, como que vai fazer?... Então, a gente punha esterco, calcário compramos tudo sozinhos. Eu falei uma vez com o presidente do Sindicato Rural de Prudente e eles nem ligaram.... (Produtor)

Em outras "falas", fica patente que os produtores que fazem parte do Sindicato Rural, só o fazem, ora devido aos serviços burocráticos prestados, ora para aquisição de insumos, ora utilizando-o como assessoria jurídica, tendo suas participações, assim, pouco ou mesmo nenhum caráter de discussão política.

A gente faz parte do Sindicato [rural de Regente, pelo menos ali...a gente é bem atendido. Agora há pouco tempo a gente comprou adubo, né? Pelo sindicato... a gente se reuniu e comprou em grande quantidade pra sair mais barato, o pessoal que faz parte do sindicato todos eles entraram....[E associação de produtores?] Eles estão comentando em fazer aqui no bairro uma Associação, mas por enquanto ainda não tem, mas tão tentando fazer sim... Eu acho que funciona, pela associação um vai ajudar o outro... O custo é menor.... (Produtor)

O Sindicato Rural aparece, assim, principalmente, como prestador de serviços aos seus membros.

Eu não faço parte de nenhuma cooperativa, mas eu tenho um sonho muito grande, que no município de Regente Feijó ou mesmo no de Presidente Prudente, deveria ter um incentivo dos prefeitos daqui da região, para que se formasse uma cooperativa dos pequenos agricultores ou pequenos horticultores, né? [...] porque já foi montada uma aqui no município, só que era uma cooperativa dos agricultores que produziam cana [de açúcar] , aí a usina foi à falência [...]. O que é funcionar: seria o prefeito destinar um barracão, destinar umas 3 a 4 pessoas pra administrar, um para sair colhendo assinaturas dos pequenos horticultores, olha você quer entrar? Você quer participar?..., mesmo que fosse cobrada uma taxa de manutenção, olha nós vamos ter lá 3 funcionários, esses funcionários vão ser sustentados através de vocês, vai ser $X$ pra cada um por mês, seria vantagem pra gente pagar, [...] teria uma pessoa ali ao dispor da gente o dia todo, para andar na cidadezinha, no supermercado: Olha, eu tenho esse produtor que produz rúcula, tenho esse produtor que produz moranguinho, esse outro produtor que produz alface americana, outro produz alface crespa e a 
gente consegue manter aqui tantos maços de alface todo mês e aí fazer o negócio funcionar. [...]. Agora a gente só vender em feira fica limitado, porque você não consegue expandir a sua produção, você fica limitado naquela produção, produz aí $X$ maços por semana e não tem condição de aumentar porque não tem para quem vender. Eu sou uma pessoa muito curiosa nesta área de cooperativas, eu acho que realmente funciona, [...] seria através dessas cooperativas que nós íamos ter um intercâmbio para fornecer para um local distante. Não adianta produzir aqui 10 mil pés de alface por mês se eu não tenho balcão frigorífico, se eu não tenho caminhão refrigerado para mandar para uma cidade que está daqui a 500 km, eu não tenho condição. (Produtor)

De maneira geral, observa-se que $74 \%$ dos produtores familiares entrevistados fazem parte de alguma forma de representação social ou de organização, embora estejam cientes de que, em muitas situações, elas não os representem de fato, como é o caso da COOLVAP e da Cooperativa Mista.

Já as Associações de Produtores são consideradas por eles como uma forma de organização que pode trazer benefícios sociais e econômicos, pois, ao terem suas reivindicações colocadas para o grupo e verem discutidas questões mais localizadas, as possibilidades de tomadas de decisão e mudanças efetivas são mais prováveis.

Entretanto, fica claro nos relatos tomados que, sem recursos econômicos, união e participação da maioria, pouco se pode fazer.

Ao realizar o trabalho de campo e as entrevistas perguntei quais eram os fatores que facilitavam ou dificultavam a atividade agropecuária, assim após a transcrição dos relatos dos produtores, organizo a seguir alguns deles,

a gente tem dificuldade de pegar terra [arrendar] para plantar, porque a
gente num tem a... terra, porque a gente quer plantar mais, pra ver se
tem uma renda melhor, aí se torna difícil para pegar terra, não é fácil
pegar, e outras vezes tem [terra] longe mas nós num podemos sair longe
para trabalhar, num podemos nos deslocar $20-30 \mathrm{~km}$ para trabalhar, daí
o óleo diesel pesa mais, a gasolina... vem tudo né? Aqui por esse ano a
vizinha me deu [arrendou] um pedaço de terra para nós, eu fiquei
contente, até eu preciso conversar com ela, porque eu fiquei de jogar
semente lá, pra ver se ela vai me dar algum pedaço ainda ou não.
(Produtor)

A quantidade de terra disponível para o agricultor é apontada como uma dificuldade, já que para aumentar a renda, segundo eles, há que se aumentar a produção, e conseqüentemente é preciso aumentar a área plantada. 
O mais difícil é... Eu acho que é o preço de insumo, o que mais atrapalha né ? Num tem como fugir dele, há 5-6 anos se vende ao preço que se vende hoje né? Só que [o preço] a tonelada de adubo de 5-6 anos dobrou praticamente, era 180 reais [uma tonelada], [...] quando entrou o plano depois..., hoje é 500 reais, você vendia um quilo de melancia e hoje vende ao mesmo preço, [E o combustível] Era 0.33 centavos o diesel, agora é 0.80 , e $[. .$.$] o preço para venda é o mesmo, e num é só melancia não,$ feijão, milho, é tudo por aí, isso que a gente está vendendo né? [...]. (Produtor)

Os preços dos insumos e o valor da produção são destacados como fatores que penalizam os produtores,

[...] a gente vive de esperança, né? No caso, na agricultura, a gente vive de esperança achando que no outro ano vai ser melhor e que você vai plantar e vai colher mais né?[...] o que dificulta e que você num tem preco, ás vezes você planta no escuro, é um tiro no escuro, você num sabe se vai produzir, se vai chover na época certa, $[. .$.$] a gente às vezes$ fica até torcendo para que um contratempo lá do sul venha beneficiar a gente aqui, mas aí se gear lá aí a gente vai vender o nosso aqui, porque infelizmente é assim, [...] a produção é muito grande, acaba que num consegue vender tudo né? [...] então eu acho que o que falta é interesse, o governo vê que o Brasil é um país agrícola, que tem um potencial [agrícola] que tem terra, tem que ser da agricultura mesmo, não adianta querer ficar inventando coisa, $[\ldots]$, investir muito em tecnologia e ela não ser voltada para a agricultura, eu acho que o Brasil é um país agrícola, tem terra, tem condicões de produzir.... (Produtor)

O desabafo dos agricultores foi então, na maioria das vezes, com relação aos preços alcançados na comercialização e ao governo cujas políticas públicas para a agricultura não têm atendido as necessidades desse grupo,

Aqui ajuda, o nosso clima é bom pra agricultura e para pecuária, num precisa melhor, mas o que é ruim aqui pra nós é a manutenção, os empregados, os bóia fria judiam demais, trabalham aí 10-12 dias para você e se acham no direito de reivindicar aí alguma coisa, e ganham [as causas trabalhistas], [...] então a dificuldade é aí. 0 preço é o alto e baixo né? $O$ preço hoje é uma coisa, amanhã é outra, às vezes na época que você está plantando está uma beleza de repente..... mais isso aí é uma coisa que não é [do] nosso [controle] né? Vai fazer o que, é ruim, seria bom se tivesse o preço estipulado né? Mas não é assim, mas eu acho que ela [a terra] tem que produzir, $\mathrm{X} X$ da estória é fazer ela produzir, porque ela tendo uma boa produção o preço sempre dá. [Você tem vontade de comprar terra?] A gente pensa sim, tem vontade mais é muito difícil nós também não queríamos sair daqui né? Para mexer no ramo que nós mexemos se sair daqui tem que trocar de ramo né? $\mathrm{E}$ o que nós sabemos fazer é só isso mesmo...(Produtor). 
Outras questões levantadas estão relacionadas à necessidade de contratação de mão-de-obra e o temor de se caracterizar aí vínculos empregatícios pois, os encargos sociais são considerados muito onerosos,

Eu acho que a maior dificuldade aqui pra nós é a terra, pra você achar terra é muito difícil.... é muito difícil... Eu acho que eu não ter a terra é a maior dificuldade, e eu acredito que pra todos daqui é,...eu tinha vontade de ter terra (ser proprietário)... A gente planta bastante né? Mas também num precisava ser minha a terra entendeu, ter com fartura terra pra gente arrendar, daqui uns dois anos você num vai achar nenhum palmo de terra, já está tudo plantada, tudo terra velha, a usina [Alto Alegre] pegou tudo né? Aqui num acha... cada dia que passa fica mais difícil. [Você já ouviu falar do Banco da Terra?] Já ouvi, mas eu acho que pra mim num serve pelo que eu ouvi falar, num conheço né? [...] eles vão dar 5 alqueires, parece que vai fazer uma colônia de 10-20 produtores e dar 5 alqueires pra cada um..., eu nem quero..., pra mim não funciona eu toco 30-40 [alqueires] aqui, e ter que morar em cima vai passar fome em cima dos 5 , a num ser que..., se você botar um japonês lá numa quarta que você der pra ele, ele toca, ele pega melhor que a gente né? [risos]. (Produtor)

Para aqueles que são arrendatários a maior dificuldade é encontrar terra apropriada (ligada á fertilidade) para agricultura para arrendar. Nos municípios visitados, a cana-de-açúcar tem ocupado cada vez mais as áreas agriculturáveis e já é fator de preocupação dos produtores arrendatários frente ao limite cada vez maior de áreas disponíveis para outras culturas, além do desgaste da terra que ela representaria.

O Banco da Terra, para alguns arrendatários entrevistados, não parece uma boa alternativa, desde que a quantidade de terra não seria suficiente para o sistema agrícola que eles têm praticado.

Se eu tivesse mais terra...., porque a quantidade de terra que a gente tem é pouco, então dá só pra fazer o que a gente faz, plantar horta que usa pouca terra, mas se eu tivesse condicão de ter mais terra eu ia mexer só com gado, com gado de engorda ou pra ir criando, se eu tivesse condições..., aqui é bom porque a gente faz o que quer aqui..., ninguém manda na gente, a gente mesmo, é o patrão, eu que decido o que fazer $e$ num tem que ficar mandando na gente... (Produtor)

Em outros há o desejo de, na possibilidade de ter mais terra, trabalhar só com pecuária.

Como fator positivo, sempre foi apontado entre os entrevistados a liberdade que se tem sendo produtor rural, pois é o dono do seu tempo e da sua vontade. 
O que facilita, o que é bom hoje em você trabalhar na horta é que você não tem tantos encargos fiscais, eu loto essa perua de alface e vou numa feira e vendo e não pago imposto, este seria um lado bom, mas é um a favor e nove contra porque eu tenho o tempo [clima], eu tenho a chuva que é demais, eu tenho a doença que é demais, muita bactéria, muito vírus, tem uma infinidade [de dificuldades]..., o custo de insumos, do adubo, do fertilizante, do esterco, do combustível e pra acabar de interar agora o racionamento de energia, que é o meu caso aqui, eu dependo de energia para puxar água do poço para irrigar..., mas em termos gerais..., o horticultor [o proprietário] sofre mais que qualquer empregado, o horticultor não tem a disponibilidade de falar assim: $2^{a}$ feira é feriado, eu vou parar hoje $6^{a}$ feira à tarde e fazer uma pescaria, ele não pode, a verdura é um ser vivo que depende do cuidado 12 horas por dia, só não se rega a verdura a noite, essas mudas que você está vendo, aqui eu tenho que estar cuidando 12 horas por dia, se são 11 horas os empregados vão almoçar e eu venho aqui pra molhar, as vezes vou almoçar 1-2 horas da tarde, [...] me dedicar a isso daqui a semana toda, o mês todo, o ano inteiro. (Produtor)

Por outro lado, ser dono ou arrendatário de uma unidade produtiva o torna mais ocupado e responsável. O tempo para lazer e descanso é cada vez menor para o produtor familiar que se confronta com uma infinidade de demandas em um tempo e espaço cada vez mais limitado, sob um sistema econômico que o pressiona e não o distingue.

Interessou-me também ouvir dos produtores familiares entrevistados quais eram seus planos futuros com relação á atividade que exercem. Destaco a seguir alguns depoimentos que são reveladores do pensamento e atitudes deles com relação a sua vida, sua família e seu trabalho.

A gente fazendo o que aprendeu já está difícil né? A gente tenta se aperfeiçoar, melhorar né? Para competir com o mercado, [ver] a demanda né? $O$ que a gente está tentando já do ano passado, é fazer cultura [plantar o ano inteiro culturas diferentes] né? Porque dinheiro a gente gasta todo dia, a gente diminui um pouco as áreas [de plantio] né? E vai plantando né?. [E o dinheiro da produção, como vocês trabalham com ele?] Não sobra, está que nem eu falei né? Nós temos um financiamento prolongado, uma conta aí, temos que programar mesmo para pagar, a gente prolongou tarde, e procurando trabalhar comprando á vista, para não [precisar] financiar, para ninguém tirar né? Para ficar mais barato não vamos deixar remontar, a margem é pouca então .......] .(Produtor) 
FOTOS 9 E 10 
As dificuldades econômicas são enfrentadas com determinação de quem já está nesta luta há muito tempo, a necessidade de garantir o sustento da família e de honrar compromissos assumidos exige estratégias como a intensificação do trabalho agrícola, o conhecimento de quais culturas são mais rentáveis e que os exponha a menos custos e riscos.

A gente... trabalhar por conta própria é difícil, porque você vive na corda bamba, você não tem ninguém que olhar por você, mas você vê tanta corrupção ... [...] Então você fica desanimado porque você trabalha..... , você produz..., você planta..., você não tem horizonte, na hora que vai se aposentar dá a maior briga [com a previdência], aí se aposenta para ganhar 180 reais, então quer dizer, a gente fica desanimado né? [...] a gente na roça é igual a abelha, ele vai sempre fazendo, fazendo, por que ele não tem uma estrutura, porque o cara que tem um emprego tem certeza que no final do mês ele vai receber o salário dele né? Agora o cara que trabalha por conta, muitas vezes ele tem um ano bom, ele produz bastante, só que ele tem que guardar porque ele não sabe se no outro ano ele vai ter de novo, então a gente que trabalha por conta é difícil por causa disso, a gente vive sempre inseguro, agora quando você começa a comer aquilo que você guardou você já fica desesperado, [...] você demorou muito tempo para construir e para desfazer é muito rápido, então a gente fica.., nunca ninguém na roça está animado né? Porque a gente sabe que na roça é igual a um jogo, você ganha e você perde, então você fica sempre naquela, você num vê um cara que entrou na roca e agora está rico, a num ser estes vereadores [?] que não pagam financiamento, então aí na hora que ele se vê rico também ele já sai fora da agricultura, aí ele vai investir em pecuária, em fruta menos na agricultura [?] porque a agricultura é isso, igual a um jogo, você joga... se acertar, você ganha e sai fora porque se continuar jogando você fatalmente vai perder!. Por enquanto vou continuar [com a batata doce], quer dizer num tem alternativa né? A gente fica buscando alternativa e você vai ver que todo mundo está do mesmo jeito, porque a agricultura é sempre isso né? [...] eu acho que você tem que fazer aquilo que você sabe fazer, que está mais fácil, que está perto... é a gente vive de esperanca.... achando que 0 ano que vem vai ser melhor, que você vai produzir mais....., vai ter preco..., fica sempre esperando, contando com a desgraça do outro, agora estamos esperando para exportar para Argentina, pra exportar pra Argentina precisa de frio, lá né? Tem que torcer pra fazer frio, e agora a Argentina está quebrada... $\underline{\text { O que eu acho ruim }}$ na agricultura, principalmente na agricultura pequena, assim que vocề já está muito perto do seu limite é que você não tem segurança, porque se você tem segurança você fala assim: oh, eu vou plantar essa batata, mas se ela não der você tem uma renda, pra você conseguir comer, beber né? Nosso país não tem subsídio porque roubam tudo, você vê [o governo] manda dinheiro pra comprar cestas básicas e o pessoal rouba! (Produtor)

Por vezes, o futuro na agricultura é tratado com insegurança para alguns que a enxergam como um jogo, onde se você acerta é melhor sair dele porque adiante pode perder 
tudo. Entretanto, como trabalhar a terra e produzir nela é o que sabem fazer, continuar na atividade agrícola é visto como a única alternativa para sua reprodução social e econômica.

Ah! É ficar por aqui, tudo que é outra coisa é muito difícil, porque a batata [doce] vai produzir o ano inteiro e já outras coisas tem a época do ano certa e..., nós nunca nos empenhamos em mexer com outras coisas né? E o nosso lugar aqui produz bem batata, então eu acho que num tem necessidade de ir atrás de outras coisas. A gente é o primeiro comprador da região, então a gente fica na batata mesmo. Meu menino gosta de ficar na roça com a gente em volta de mim. (Produtor)

Para aqueles que conseguem ter uma rentabilidade melhor ao, juntamente com a agricultura também, realizarem a comercialização da produção própria e de outros, o futuro é visto com mais otimismo, demonstram assim que não pretendem mudar de ramo.

Eu não tenho vontade de deixar [a agricultura] não, nem de mudar, só se for obrigado mesmo né? Os planos são de aumentar ainda mais, só que é difícil né? Mas meu plano é aumentar. [E sua filha?] Minha filha não tem vontade nem um pouco, nem eu queria também né? Ainda mais pra mulher, esse trabalho pra mulher é complicado..... (Produtor)

Ainda há os que revelam a intenção de expandir a área plantada, mesmo que no futuro não contem com a ajuda dos filhos para a continuidade de sua atividade, como relata esse produtor.

Nós estamos mudando porque, com a idade que nós temos, estamos meio cansados e os filhos estão preocupados e nós vamos mudar para cidade né? Agora vamos alugar [o sítio] para festas... estamos começando, o plano é ter uma área de lazer para (alugar) nos fins de semana. Os filhos moram todos em São Paulo [...]. Eu acho que eles não pensam em morar aqui não. (Produtor)

Para outros o futuro era de mudança. Aqueles que estavam se "aposentando” da atividade agropecuária devido á idade e cujos filhos já tinham outras profissões fora do campo. Era visível neles a tristeza em ter que deixar uma vida no sítio para morar na cidade.

Por enquanto eu vou continuar [na mesma atividade], vou arrendar uma pequena área, são uns 2 hectares próximos daqui, onde tem mais água né? É... a minha vontade, então eu estou pretendendo plantar mais... de tudo: pimentão, berinjela, vagem, jiló, abobrinha...legume e futuramente a gente vê se está compensando... [Você já pensou em ir embora daqui?] Não, não pretendo sair daqui não. (Produtor) 
Alguns ainda pretendem ampliar a área plantada através de arrendamento na intenção de aumentar a produção e a renda e, mesmo com as dificuldades que dizem encontrar, não pretendem mudar de atividade.

Eu tenho plano de diversificar e ampliar, mas ao mesmo tempo a gente fica preso a dificuldade financeira, se eu tivesse hoje um incentivo do governo, e... 0 gerente do banco chegasse aqui na porta da propriedade que eu arrendo e falasse: Olha aqui tem uma verba que o governo está destinado aos pequenos produtores, você não vai precisar ir atrás de endossante [...] se eu tivesse condição eu ia aumentar a produção de moranguinhos que tem uma aceitação muito boa no mercado, eu ia plantar legumes que eu tenho prática, eu planto isso aí desde criança, berinjela, abobrinha, chuchu, tomate, vagem, pepino rasteiro e envarado, eu tenho muita prática em legumes, e sonho também em ter minha propriedade. Ficar livre do aluguel (da terra) [...]. (Produtor)

As limitações de ordem financeiras foram freqüentemente citadas, juntamente com as limitações de ordem fundiária como aquelas que impediriam os produtores familiares de vislumbrarem um futuro mais promissor.

Contudo, mesmo frente a tudo que vi e ouvi deles ficou, mais do que nunca, o registro de um grupo que surpreendentemente está em constante superação das adversidades e dificuldades que surgem em seus caminhos. 


\section{CONSIDERAÇÕES FINAIS}

Após esse estudo e conseqüente reflexão tenho a satisfação de ter trilhado um caminho que me possibilitou conhecer, aprendendo.

Nesse aprendizado, nunca é demais destacar que no Brasil, a agricultura familiar engloba 4,2 milhões de propriedades, emprega 14 milhões de pessoas, 77\% da mãode-obra rural. Além disso ela é responsável por 38\% da produção agrícola e muitos dos produtos que compõem a cesta básica são advindos dela.

E no espaço rural da região de Presidente Prudente, esse setor também merece destaque pois, são responsáveis por volume expressivo da produção de culturas como a mandioca, a batata doce, a melancia, a manga, o maracujá entre outras; bem como na produção animal e vegetal, que no valor total da produção, em seu conjunto, representou $63,7 \%$ e $36,3 \%$ respectivamente.

Finalizando este trabalho de pesquisa, que buscou compreender a dinâmica espacial do Sudoeste Paulista, destaquei o papel representado pelo produtor familiar rural, através de uma abordagem social e econômica, ficou mais do que evidente a importância que esses sujeitos sociais desempenham para o dinamismo da região.

O exercício, nessa pesquisa, foi o de se olhar a realidade não pela lógica do mercado e pela aparência, mas sondando processos sociais e políticos, num caminho que me levou a tentar compreender as contradições e diversidades contidas neles.

Com relação a esse segmento da população produtiva agrícola, ou seja, os produtores familiares rurais, cumpre ressaltar, aqui, a complexidade de se definir esses sujeitos, devido à heterogeneidade neles contida. Contudo, tal complexidade não deve ser obstáculo para aqueles que buscam avanços teóricos e práticos para essas questões, mas sim motivações para novas pesquisas.

Acredito também que os sujeitos sociais são os que podem transformar situações que afligem as sociedades, através da atuação política e da reivindicação direta, contudo esse grupo pesquisado revelou-se, ainda, politicamente conservador tendo, conseqüentemente, pouca força de reivindicação por mudanças. 
No aspecto da produção agropecuária, diversos estudos revelam que está na diversificação das economias agrícolas regionais o segredo da alteração do grau de desenvolvimento das atividades de origem rural.

Desta forma, setores que foram considerados outrora ineficientes, hoje são tidos como fundamentais para dinamizar espaços produtivos através do trabalho, da renda gerada por ele e de sua distribuição, nos quais se destaca, mais uma vez, a atuação do agricultor familiar.

Entretanto, reconheço que esses sujeitos sociais devem procurar superar problemas de forma conjunta, tanto no seu grupo, quanto, com a sociedade e com o poder público do qual fazem parte.

Ao serem analisados processos gerais, o período estudado ressaltou principalmente as décadas de 1980 e 1990, por terem sido décadas nas quais se assistiu ao aumento das desigualdades e da exclusão social da maior parte da população brasileira.

Elas trouxeram, também, mudanças profundas nos aspectos político, social e econômico. Com a economia brasileira cada vez mais voltada ao mercado externo, houve no setor agropecuário, uma acentuação dos problemas ligados ao papel desempenhado pela agricultura.

O modelo econômico vigente privilegiou outros setores econômicos; contudo, presenciou-se, também, a organização e a posterior consolidação de movimentos sociais, com reivindicações que têm trazido mudanças na estrutura agrária brasileira, embora ainda insuficientes para uma população excluída da terra e de seus meios de produção.

Constata-se ainda uma concentração de terra que persiste em aumentar; todavia, verificou-se também que, na outra ponta, ou seja, as unidades produtivas com áreas menores, têm aumentado. Tal realidade demonstra a complexidade de se compreender também os processos sócio-espaciais.

A participação e o acesso aos recursos creditícios e de comercialização, através das políticas públicas implementadas para o setor agrícola, com destaque para o PRONAF, não têm atendido as demandas "reais" dos produtores familiares, ao manter em suas bases uma lógica que ainda privilegia o latifúndio e a grande exploração agrícola de produtos exportáveis. Muitos ajustes devem ser realizados, ressaltando-se entre eles, uma forma de distribuição dos recursos que tente inserir o produtor no mercado, de forma coletiva e com menores exigências de garantias. 
Em se tratando de processos mais específicos, a formação histórica da região analisada demonstrou que a atividade pecuária sempre ocupou um maior espaço, tanto em termos fundiários como em termos econômicos.

A estrutura fundiária regional reflete também a estrutura agrária brasileira, ou seja, o predomínio do latifúndio, embora também houvesse a presença de pequenas propriedades. As atividades agrícolas praticadas desde o segundo quartel do século $\mathrm{XX}$ sempre estiveram subordinadas às demandas econômicas de produção agrícola de cada período, nas quais o agricultor estava submetido ora ao sucesso, ora ao fracasso de sua safra.

As condições históricas, econômicas, políticas e sociais levaram principalmente os agricultores, fossem eles proprietários, arrendatários ou parceiros, com menores disponibilidades financeiras a serem duramente penalizados.

Esses processos, entre outros, levaram a uma acentuação dos problemas regionais, tais como a migração da população rural e a exclusão de grande parcela da população. Não obstante, uma parcela destes produtores agrícolas têm persistido na atividade através de estratégias produtivas.

Desta maneira, os produtores rurais entrevistados têm buscado através da diversificação das culturas praticadas; da contratação de mão-de-obra temporária para auxiliar nas diversas etapas da produção agrícola; da formação de áreas, antes ocupadas com agricultura, em pastagens para a atividade pecuária de leite, que lhes garante uma rentabilidade mensal; da conscientização de que a organização social dos agricultores, seja em associações ou em cooperativas, pode protegê-los e auxiliá-los em problemas como a intensa intermediação na comercialização; da busca por suficiência de crédito para as atividades desenvolvidas; de custos de produção cada vez menos onerosos, entre outras estratégias e ações adotadas, possibilidades de reprodução social e econômica.

O grupo de agricultores familiares pesquisados, como já salientado, são politicamente conservadores e tradicionais em suas relações sociais. Contudo, a experiência de adentrar nesse universo me possibilitou desvendar a riqueza da vida e do trabalho de um grupo social, pouco visível para alguns, pois persiste na sociedade urbana a idéia de ineficiência e de atraso das unidades produtivas em que o núcleo familiar rural organiza sua vida e seu trabalho.

Em oposição a esse pensamento, esta pesquisa pôde demonstrar a importância que esses sujeitos sociais desempenham para o dinamismo da região, mesmo em 
face de limitações de ordem fundiária, tecnológica, de recursos financeiros e de comercialização, entre outros aspectos.

No sentido de apontar caminhos, esse estudo revelou que em relação às mudanças técnicas e incorporação de tecnologias o grupo pesquisado revelou conhecimento e adoção de algumas delas, entretanto, os custos dessas práticas são seu maior limitante, já que dificilmente o produtor consegue, através da produção final, cobrir essas despesas. Sendo assim, é necessário o desenvolvimento de técnicas e tecnologias que fossem mais acessíveis aos produtores.

Outra questão preocupante, segundo observado no levantamento de campo, é o número insuficiente de técnicos e agrônomos de instituições públicas para o atendimento aos produtores rurais familiares. Aponto que seja fundamental a implementação de mudanças nessa situação.

A comercialização da produção é também um outro fator que merece atenção pois os produtores ficam vulneráveis à intermediação.

Constata-se, que a grande dificuldade da agricultura familiar não é produzir, mas, sim, ter o retorno, via mercado do valor gerado na atividade agropecuária.

Com relação às formas de representação social do grupo pesquisado, que ainda são incipientes, cabe apontar que o melhor caminho para superar obstáculos é poder ser sujeito das decisões, que deverão ser tomadas em conjunto.

Assim, acredita-se também que seja imperativo aliar forças institucionais, através de políticas públicas; de ações da sociedade civil; da atuação das universidades, com apoio em pesquisa e acesso às modernas tecnologias de seus centros de experimentação e difusão; de um apoio técnico mais eficiente; bem como a criação de canais de comercialização que fossem favoráveis a esse grupo produtivo, já que se observou, por exemplo, que os assentamentos ligados aos programas de reforma agrária têm proporcionado um aquecimento do comércio e de setores de serviços, nos municípios localizados em seu entorno.

Enfatiza-se, por fim, que a produção familiar rural representa um papel social e econômico importante para o desenvolvimento regional, na medida em que seu fortalecimento tem tanto um valor social, através da terra, do trabalho e da família, como um valor econômico, pois a geração de renda e de empregos dinamiza o consumo e a procura por serviços. 


\section{REFERÊNCIAS BIBLIOGRÁFICAS}

ABRAMOVAY, Ricardo. De camponeses a agricultores: paradigmas do capitalismo agrário em questão. Campinas: UNICAMP, 1990. Tese (Doutorado)

. As armadilhas da pequena produção. Informações Econômicas, São Paulo, v.23, supl.1, p.01-58, 1993.

. Agricultura familiar e capitalismo no campo. In: STÉDILE, João Pedro. A questão agrária hoje. Porto Alegre: Editora da Universidade/ UFRGS, p.94-104, 1994.

ABREU, Dióres Santos. Formação histórica de uma cidade pioneira paulista: Presidente Prudente. Presidente Prudente: Publicação da Faculdade de Filosofia, Ciências e Letras, 1972.

ALTHUSSER, Louis. Ideologia e aparelhos ideológicos do Estado. Lisboa: Presença, 1980.

AMIN, Samir, VERGOPOUlOS, Kostas. A questão agrária e o capitalismo. Rio de Janeiro: Paz e Terra 1977.

ANTONIO, Armando Pereira. Movimento social e a organização do espaço rural nos assentamentos populacionais dirigidos pelo Estado. Os exemplos na Alta Sorocabana no período 1960-1990. 1990. 178 p. Tese (Doutoramento em Geografia Humana) - Faculdade de Filosofia, Letras e Ciências Humanas, Universidade de São Paulo, São Paulo, 1990.

ANTUNIASSI, Maria Helena Rocha. O trabalho familiar na agricultura paulista. 1983. 141 p. Tese (Livre Docência) - Faculdade de Ciências Agronômicas. Universidade Estadual Paulista, Botucatu, 1983.

. Pequena propriedade na agricultura do Estado de São Paulo: camponeses ou empresa capitalista? Cadernos do CERU, São Paulo, n.2, Série II, p. 47-63, 1987.

. Família camponesa na bibliografia sócio-antropológica sobre o meio rural: padrões culturais e obtenção dos meios de vida. Cadernos do CERU, São Paulo, n.5, p.100-8, 1994.

ARRUDA, Zenith João de. Bovinocultura de corte no Brasil e perspectivas para o setor. Campo Grande: EMBRAPA - CNPGC, 1994. 28 p. (Documentos, 60)

AZEVEDO, Maria Eduarda. A política agrícola comum: uma política controversa na hora da mudança. Coimbra: Almedina,1996. 263p.

BENITES, Miguel Gimenez. Brasil central pecuário: interesses e conflitos. 1995. Tese (Doutorado) - Faculdade de Filosofia, Letras e Ciências Humanas, Universidade de São Paulo, São Paulo, 1995. 
.Os frigoríficos da Grande São Paulo e arredores: Estudo Geográfico. 1978. Dissertação (Mestrado) - Faculdade de Filosofia, Letras e Ciências Humanas, Universidade de São Paulo, São Paulo, 1978.

BLUM, Rubens. Agricultura familiar: estudo preliminar da definição, classificação e problemática. In: TEDESCO, João Carlos (Org). Agricultura familiar - Realidades e Perspectivas. Passo Fundo: Edit. Universidade Passo Fundo, 1999. 349 p.

BOBBIO, Norberto, MATTEUCCI, Nicola, PASQUINO, Gianfranco. Dicionário de política. Tradução de Luís Guerreiro Pinto Cacaes. Brasília: UNB, 1986.

BRASIL. BANCO CENTRAL Anuário Estatístico de Crédito Rural. Brasília: Banco Central do Brasil, 2000.

BRASIL. Ministério da Agricultura e Abastecimento - MAA. PRONAF - Programa Nacional de Fortalecimento da Agricultura Familiar. Brasília: MAA, 1996. 37 p.

BRASIL. Ministério do Desenvolvimento Agrário - Secretaria da Agricultura Familiar. Projetos financiados pelo PRONAF infra - estrutura e Serviços Municipais http://www.incra.gov.br, Abr. de 2000.

BRASIL. Ministério do Planejamento e Coordenação Econômica, Programa de ação econômica do governo 1964-1966 (síntese). Brasília, 1964. p.15.

BRASIL. Ministério do Planejamento e Coordenação Geral. Diretrizes de governo. Programa Estratégico de Desenvolvimento.Brasília, 1967.

BRASIL. Presidência da República. Plano Trienal de Desenvolvimento Econômico e Social 1963-1965 (síntese). Brasília, 1962. p.140.

BRASIL. Presidência da República. Metas e Bases Para a Ação de Governo. Brasília, 1970. p. 89.

BRASIL. Presidência da República. I Plano Nacional de Desenvolvimento (PND) 1972/74. Brasília, 1971.

BRASIL. Presidência da República. II Plano Nacional de Desenvolvimento (1975-1979). Brasília, 1974. p. 28-9.

BRAY, Sílvio Carlos. A cultura da cana-de-açúcar no vale do Paranapanema - um estudo de Geografia Agrária. 1980. Tese (Doutorado) - Faculdade de Filosofia, Letras e Ciências Humanas, Universidade de São Paulo, São Paulo, 1980.

BUAINAIN, A. M. Agricultura pós-cruzado (euforia e crise). In: CARNEIRO, R. A política econômica do cruzado. Campinas: ed. Unicamp, 1987. p.73-109.

CALAÇA, Manuel. Características da pequena produção no Estado do Acre. 1983. 253 p. Dissertação (Mestrado em Geografia) - Instituto de Geociências e Ciências Exatas, Universidade Estadual Paulista, Rio Claro, 1983. 
CAMPANHOLE, Hilton Lobo. Legislação agrária. São Paulo: Atlas, 1980, p. 9-65.

CÂNDIDO, Antonio. Os parceiros do Rio Bonito. Rio de Janeiro: José Olympio, 1964. 233 p. (Coleção Documentos Brasileiros, 118).

CARDOSO, Ciro Flamarion. Camponês, campesinato: questões acadêmicas, questões políticas. In: CHEVITARESE, André Leonardo. (Org.). O campesinato na história, Rio de Janeiro: Relume Dumará: FAPERJ, 2002. p.19-38.

CARNEIRO, Maria José. Agricultores familiares e Pluriatividade: tipologias e políticas. In: COSTA, Luiz Flávio Carvalho et al. Mundo rural e tempo presente. Rio de Janeiro: Maud, 1999. p. 325-344.

CHAYANOV, Alexander V. La organización de la unidad económica campesina. Buenos Aires: Nueva Vision, 1974.

CICOUREL, Aaron. Teoria e método em pesquisa de campo. In: Guimarães, Alba Z. (org). Desvendando máscaras sociais. 2.ed. Rio de Janeiro: Livraria Francisco Alves Editora, 1980.

COBRA, Amador Nogueira. Em um recanto do sertão paulista. São Paulo, s.n., 1923.

CORRÊA, Roberto Lobato. Trajetórias geográficas. Rio de Janeiro; Bertrand Brasil, 1997

COSTA JÚNIOR, E.M.A. et al. O potencial da pecuária de corte nas regiões tropicais e subtropicais da América Latina. Campo Grande, EMBRAPA- CNPGC, 1987. 17 p. (Documentos, 22)

DAdOS PRUDENTE. Prefeitura Municipal de Presidente Prudente. Assessoria de Assuntos Estratégicos - Gestão 1997-2000. 1998.58 p.(impressso)

DELGADO, Guilherme da C. Capital financeiro e agricultura no Brasil. São Paulo: Ícone editora, Campinas: Ed. Unicamp, 1985. 240 p. (Coleção América Latina).

Tendências da demanda agrícola face a política econômica. In: Congresso Brasileiro de Economia e Sociologia Rural, 26, Fortaleza, 1988. Anais... Brasília: SOBER, 1988. p.71104.

DESER - DEPARTAMENTO DE ESTUDOS SÓCIO-ECONÔMICOS RURAIS. Novas regras do PRONAF. Curitiba, 1999. 7 p.

DIAGNÓSTICO da situação da agropecuária na região de Presidente Prudente. Presidente Prudente, Secretária da Agricultura e do Abastecimento, 1997. (mimeografado)

DICIONÁRIO de Sociologia. Porto Alegre: Globo, 1974. 
FERNANDES, Bernardo M. Espacialização e territorialização da luta pela terra: a formação do MST, Movimento dos Trabalhadores Rurais Sem Terra no Estado de São Paulo. 1994. Dissertação (Mestrado em Geografia Humana) - Faculdade de Filosofia, Letras e Ciências Humanas, Universidade de São Paulo, São Paulo, 1994.

Espaços agrários de inclusão e exclusão: Novas configurações do campo brasileiro. Trabalho apresentado no XV ENGA. Petrolina, 2002.

RAMALHO, Cristiane Barbosa. Luta pela terra e desenvolvimento rural no Pontal do Paranapanema. Estudos Avançados, nº 43, p.239-254, 2001.

FERREIRA, Aurélio Buarque de Holanda. Novo dicionário Aurélio. São Paulo: Nova Fronteira, 1975.

FERREIRA, Darlene Ap. de O. O mundo rural sob o ponto de vista geográfico: a trajetória da Geografia Agrária Brasileira na década de 30 à de 90. 1998. 389 p. Tese (Doutorado em Geografia) - Instituto de Geociências e Ciências Exatas, Universidade Estadual Paulista. Rio Claro, 1998.

FERREIRA, Enéas R; BRAY, Silvio C. As influências do Pró-Álcool e do Pró-Oeste nas transformações das áreas canavieiras do Estado de São Paulo. Geografia, Rio Claro, v. 9, n. 17-18, p. 101-13, 1984.

FRANÇA, Ary. A marcha do café e as frentes pioneiras. Rio de Janeiro: Conselho Nacional de Geografia, 1960.

FUKUI, Lia F. G. Estudos Clássicos de sociologia agrária: comunidades, estruturas agrárias, caracterização da camada camponesa. Ciência e Cultura, v. 27, n.6, p.607-12, jun. 1975.

FUNDAÇÃO INSTITUTO BRASILEIRO DE GEOGRAFIA E ESTATÍSTICA (FIBGE). Censos Agrícolas do Estado de São Paulo de 1950 e 1960. Rio de Janeiro: FIBGE.

FUNDAÇÃO INSTITUTO BRASILEIRO DE GEOGRAFIA E ESTATÍSTICA (FIBGE). Censos Agropecuários do Estado de São Paulo de 1970, 1975, 1980, 1985 e 1995/96. Rio de Janeiro: FIBGE.

FUNDAÇÃO INSTITUTO BRASILEIRO DE GEOGRAFIA E ESTATÍSTICA (FIBGE). Censos Agropecuários do Estado de São Paulo de 1995/96. Rio de Janeiro: FIBGE, 1999. http;//www.sidra.ibge.gov.br.

FUNDAÇÃO INSTITUTO BRASILEIRO DE GEOGRAFIA E ESTATÍSTICA (FIBGE). Censos Agropecuários do Estado de São Paulo de 2000. Rio de Janeiro: FIBGE, 2000. http;//www.sidra.ibge.gov.br.

FUNDAÇÃO INSTITUTO BRASILEIRO DE GEOGRAFIA E ESTATÍSTICA (FIBGE). Censos Demográficos do Estado de São Paulo de 1950, 1960, 1970, 1980 e 1991. Rio de Janeiro: FIBGE. 
FUNDAÇÃO INSTITUTO BRASILEIRO DE GEOGRAFIA E ESTATÍSTICA (FIBGE). Contagem Nacional da População de 1996. Rio de Janeiro: FIBGE, 1996.

FUNDAÇÃO INSTITUTO BRASILEIRO DE GEOGRAFIA E ESTATÍSTICA (FIBGE). Contagem Nacional da População de 2000. Rio de Janeiro: FIBGE, 2000.

FUNDAÇÃO INSTITUTO BRASILEIRO DE GEOGRAFIA E ESTATÍSTICA (FIBGE). Pesquisa Pecuária Municipal de 1996. Rio de Janeiro: FIBGE, 1996.

FUNDAÇÃO INSTITUTO BRASILEIRO DE GEOGRAFIA E ESTATÍSTICA (FIBGE). Produção Agrícola Municipal, 1990, 1991, 1992, 1993, 1994, 1995 e 1996. Rio de Janeiro: FIBGE, 1996.

FUNDAÇÃO SEADE. A interiorização do desenvolvimento econômico no Estado de São Paulo, 1920-1980. São Paulo: SEADE,1988 (COLEÇÃO Economia Paulista; v.1, nº 2)

GARCIA JÚNIOR, Afrânio R. Terra de trabalho: trabalho familiar de pequenos agricultores. Rio de Janeiro: Paz e Terra, 1976. 236 p.

GIANOTTI, José Arthur. Trabalho e Reflexão: Ensaios Para uma Dialética da Sociabilidade. São Paulo: Brasiliense, 1983.

GILBERT, Anne. The New Regional Geography in English and French-speaking Countries. Progress in Human Geography, 12(2), 1988.

GONÇALVES NETO, Wenceslau. Estado e agricultura no Brasil: política agrícola e modernização econômica brasileira - 1960 - 1980. São Paulo: HUCITEC, 1997. 245 p.

GRAZIANO DA SILVA, José (org). Estrutura agrária e produção de subsistência na agricultura brasileira. São Paulo: HUCITEC, 1978. ed.: 1964).

Quatro séculos de latifúndios. 4.ed. Rio de Janeiro: Paz e Terra. 1983. 197 p. (1

. Mas qual reforma agrária? Reforma agrária, Campinas, v. 17, n. 01, p. 17-60, abr/jul. 1987.

. O novo padrão agrícola brasileiro: do complexo rural aos complexos agroindustriais. In: Delgado et al. Agricultura e políticas públicas. Brasília: IPEA, 1990. (Série IPEA, n. 127, cap. 2)

. O desenvolvimento do capitalismo no campo brasileiro e a reforma agrária. In:. STÉDILE, João Pedro. A questão agrária hoje. Porto Alegre: Ed. da Universidade/ UFRGS, 1994. p.137-43

A nova dinâmica da agricultura brasileira. Campinas, SP. UNICAMP. IE, 1996.

et al. Tecnologia e campesinato: o caso brasileiro. Revista de Economia Política, São Paulo, v. 3, p. 21-55, n.4, out/dez. 1983. 
GOTTDIENER, Mark. A produção social do espaço urbano. São Paulo: EDUSP, 1997.

GRZYBOWSKI, Cândido. Caminhos e descaminhos dos movimentos sociais no campo. Rio de Janeiro: Fase/Vozes, 1986. 90 p.

GUIMARÃES, A. Passos. A crise agrária. Rio de Janeiro: Paz e Terra, 1979. 362 p.

HARVEY, David. Condição Pós-Moderna. Edições Loyola. 1992.

HEREDIA, Beatriz M. A morada da vida: trabalho familiar de pequenos produtores do nordeste do Brasil. Rio de Janeiro: Paz e Terra, 1979. 164 p. (Estudos sobre o Nordeste, 7).

HESPANHOL, Rosângela Aparecida de Medeiros. Produção Familiar: Perspectivas de análise e inserção na Microrregião Geográfica de Presidente Prudente. 2000. 354 p. Tese (Doutorado em Geografia) - Instituto de Geociências e Ciências Exatas, Universidade Estadual Paulista. Rio Claro, 2000.

IANNI, Otávio. A luta pela terra. Petrópolis: Vozes, 1981.

. As relações de produção na agricultura. In: Seleção de textos, $n^{0} 2$, São Paulo: AGB - São Paulo, 1977. p. 1- 29.

IGREJA, Abel C. M. Evolução da pecuária bovina de corte no estado de São Paulo no período 1969-84. 1987. Dissertação (Mestrado), USP, Piracicaba, 1987.

JANK, Marcos S. et al. A OMC e o Agronegócio: O Desafio da Rodada do Milênio. In: PREÇOS AGRÍCOLAS, MERCADO E NEGÓCIOS AGROPECUÁRIOS, ano XIV, n.156, p.8, Outubro,1999. USP/ESALQ

JORNAL Folha de São Paulo. São Paulo, 11 out. 1999, Caderno A, p.5; 22 mai. 2000, Caderno A, p.11; 11 jun. 2000, Caderno B, p.8; 27 abr. 2002, Caderno A, p.6; 16 set. 2002, Caderno A, p.4-5; 17 fev. 2003, Caderno A, p.6.

JULLIARD, Etienne. L’ information Geographique. Boletim Geográfico, Paris, n.149, p.8590, mar/abr.1959.

KAGEYAMA, Ângela. Modernização, produtividade e emprego na agricultura: uma análise regional. 1985. 463 p. Tese (Doutorado em Economia) - Instituto de Economia, Universidade de Campinas, Campinas, 1985.

BERGAMASCO, Sonia M. P. P. A estrutura da produção no campo em 1980. Perspectivas, São Paulo, n. 12-13, p.55-72, 1989/90.

A questão agrária brasileira: interpretações clássicas. Revista da Associação Brasileira de Reforma Agrária, v. 23, p.99, set/dez 1993. 
KAHIL, Samia P. A luta dos posseiros em Lagoa São Paulo: A dialética da construção/ destruição do território para o trabalho livre. 1984. 128 p. Dissertação (Mestrado em Geografia) - Instituto de Geociências e Ciências Exatas, Universidade Estadual Paulista, Rio Claro, 1984.

KAUTSKY, Karl. A questão agrária. São Paulo: Abril/Nova Cultural, 1986 (Coleção Os Economistas).

LAMARCHE, Hughes (coord). A agricultura familiar: comparação internacional - I uma realidade multiforme. Trad. Angela M. N. Tijiwa. Campinas: Edit da Unicamp, 1993. 336 p. (Coleção Repertórios). v. 2, 348 p.

A agricultura familiar: do mito à realidade - II. Campinas: Edit da Unicamp, 1997.

LAZZARINI NETO, Sylvio et al. Pecuária de corte moderna: produtividade e lucro. São Paulo, s.n., 1996.

LECOQ-MÜLLER, Nice. Sítios e sitiantes no Estado de São Paulo. Geografia, São Paulo, n.7, p.10-215, 1951.

LECOQ-MÜLLER, Nice. Bairros Rurais no município de Piracicaba. Boletim Paulista de Geografia, São Paulo, n. 43, p.83-130, 1966.

LEITE, José Ferrari. A Alta Sorocabana e o espaço polarizado de Presidente Prudente. Presidente Prudente: FFCL, 1972.

A ocupação do Pontal do Paranapanema. 1981. 256 p. Tese (Livre Docência) Instituto de Planejamento e Estudos Ambientais, Universidade Estadual Paulista, Presidente Prudente, 1981.

A ocupação do Pontal do Paranapanema. São Paulo: HUCITEC, 1998.

LENCIONI, Sandra. Região e Geografia. São Paulo: Editora da Universidade de São Paulo,1999.

LÊNIN, Vladimir H. Capitalismo e agricultura nos Estados Unidos da América: novos dados sobre as leis do desenvolvimento do capitalismo na agricultura. São Paulo: Brasil Debates, 1980.

O desenvolvimento do capitalismo na Rússia: o processo de formação do mercado interno para a grande indústria. São Paulo: Nova Cultural, 1985.

LINHARES, Maria Yedda Leite Linhares. Possibilidades da História comparada no Brasil. A História agrária como uma experiência de pesquisa. In: CHEVITARESE, André Leonardo (org.). O campesinato na história. Rio de Janeiro: Relume Dumará: FAPERJ, 2002. p.141150. 
LOPES, Juarez R. B. Empresas e pequenos produtores no desenvolvimento do capitalismo agrário em São Paulo (1940-1970). Estudos CEBRAP, São Paulo, n.22, p.43-110,1977.

LOUREIRO, Maria Rita Garcia. Parceria e capitalismo. Rio de Janeiro: Zahar Editores, 1977. $135 \mathrm{p}$.

MACHADO, Eduardo Paes et al. Poder e participação política no campo. São Paulo: CENEA,1987.

MAGINA, Manuel Augusto de A. Espaço agrário e modernização produtiva. Uma abordagem espacial dos investimentos públicos - o vale do rio São João (RJ). 1993. Dissertação (Mestrado) - UFRJ, 1993.

MAMIGONIAN, Armen. Notas sobre os frigoríficos do Brasil central pecuário. In: Boletim Paulista de Geografia. São Paulo, v. 51, p.7-14, jun.1976.

MARION, José C. Contribuição à contabilidade da pecuária bovina de corte. 1982. Dissertação (Mestrado) - FEA/USP, São Paulo, 1982.

MARSDEN, Terry. Exploring a rural sociology for the fordism transition: Sociologia ruralis. Londres, Vol.XXXII (2/3), 1992.

MARTINE, George, GARCIA, Ronaldo. Os impactos sociais da modernização agrícola. São Paulo: Caetés, 1987.

MARTINS, José de Souza. A imigração e a crise no Brasil agrário. São Paulo: Pioneira Editora, 1973. 178 p.

Capitalismo e tradicionalismo: estudos sobre as contradições da sociedade agrária no Brasil. São Paulo: Pioneira, 1975. 161 p.

O cativeiro da terra. São Paulo, Ed. HUCITEC, 1979. 157 p.

Expropriação e violência. São Paulo: Ed. HUCITEC, 1980. 181 p.

. A reforma agrária e os limites da democracia na nova república. São Paulo: HUCITEC, 1986a.

. Não há terra para plantar nesse verão. Petrópolis: Vozes, 1986 b.

. Caminhada no chão da noite. São Paulo: HUCITEC, 1989. 147 p.

. Os Camponeses e a política no Brasil. 5.ed. Petrópolis: Vozes, 1995. 185 p.

Reforma Agrária: O impossível diálogo. São Paulo: Editora da Universidade de São Paulo, 2000. 173 p. 
MARTINS, Olímpio Beleza. O uso do solo no município de Presidente Bernardes. 1974. 206 p. Dissertação (Mestrado em Geografia Humana) - Faculdade de Filosofia, Letras e Ciências Humanas, Universidade de São Paulo, São Paulo, 1974.

MEDEIROS, Célia Maria Santos V. O tradicional e o moderno na atividade pecuária de corte: Produtores rurais pecuaristas residentes em Presidente Prudente. 1997. Dissertação (Mestrado) - FCT/UNESP, Presidente Prudente, 1997

MEDEIROS, Leonilde S. História dos movimentos sociais no campo. Rio de Janeiro: Fase, 1989. $215 \mathrm{p}$.

MENDES, Noeli Ap. S. Reassentamento rural Rosana: trajetória de vida e organização das atividades econômicas. 1998. 135 p. (Monografia de Bacharelado) - FCT/UNESP, Presidente Prudente, 1998.

MENDRAS, Henry. Sociétés paysannes. Paris: Armand Colin, 1976. 236 p.

La fin des paysans. Paris: Actes Sud, 1984. 437 p.

MONBEIG, Pierre. Notas relativas à evolução das paisagens rurais no Estado de São Paulo. Boletim Geográfico, Ano II, n. 16, p.428-30, 1944.

Novos estudos de geografia humana brasileira. São Paulo: Difel, 1957.

. Pioneiros e fazendeiros de São Paulo. São Paulo: HUCITEC/Polis, 1984. 392 p. (1 $1^{\mathrm{a}}$ ed. 1952).

MOREIRA, Roberto J. A pequena produção e a composição orgânica do capital. Revista de Economia Política, São Paulo, v. 1 , p.41-55. n.3, jul./set. 1981.

Agricultura familiar e assentamentos rurais: competitividade, tecnologia e integração social. In: Ferreira, A. D. D. e Brandenburg, A. (orgs). Para pensar outra agricultura, Curitiba, Ed. da UFPR, 1998. 1999. 198 p.

Agricultura familiar: processos e competitividade. Rio de Janeiro: UFRRJ/CPDA,

MÜLLER, Geraldo. Competitividade e integração econômica e social: Para uma gestão regional das questões agrárias e agroindustriais. Rascunho, n.32, UNESP - Rio Claro, 1994.

.100 anos de República: notas sobre as transformações estruturais no campo. Revista de Estudos Avançados, São Paulo, v. 3, n. 7, p. 110, 1989. 1989. 149 p.

Complexo agro-industrial e modernização agrária. São Paulo: HUCITEC/EDUC, . Ambivalências da modernização agrária. Novos Estudos CEBRAP, n. 21 p. 168-84, jul.1988. 
. Complexo agro-industrial. São Paulo: Fundação Getúlio Vargas. 1981. 114p. (relatório de Pesquisa, 13)

NAKANO, Yoshiaki. A destruição da renda da terra e a taxa de lucro na agricultura. Revista de Economia Política, São Paulo, v. 1. n.3, jul./set. 1981.

OCDE. Territorial indicators of employment, Paris: OCDE, 1996.

OLIVEIRA, Ariovaldo Umbelino de. Agricultura e indústria no Brasil. São Paulo: AGB, n. 58, 1981.

Modo capitalista de produção e agricultura. São Paulo: Ática, 1986. 88 p. (Princípios, 68).

A agricultura camponesa no Brasil. São Paulo: Contexto, 1991. 164 p. (Caminhos da Geografia)

. Geografia e território: Desenvolvimento e contradições na agricultura. In: Encontro Nacional de Geografia Agrária, 12., 1994, Rio Claro. Anais ... Rio Claro: IGCE, 1994.

O campo brasileiro no final dos anos 80. In: STÉDILE, João Pedro. A questão agrária hoje. Porto Alegre: Editora da Universidade/ UFRGS, 1994.

Agricultura brasileira desenvolvimento e contradições In: Geografia e meio ambiente no Brasil. São Paulo: HUCITEC, 1995.

OLIVEIRA, Francisco. A economia brasileira: crítica à razão dualista. Seleções CEBRAP, n.1, p.06-78, 1976.

OLIVEIRA, Márcio Pinon de. Geografia e epistemologia: meandros e possibilidades metodológicas. In: Revista de Geografia, UNESP, São Paulo, v.14, 1997, p.154.

PAIVA, Ruy Miller. Modernização e dualismo tecnológico na agricultura: uma reformulação. Pesquisa e Planejamento Econômico, Rio de Janeiro, v.5, n.1, p. 117- 61, jun.1975.

PEREIRA, Aparecido de Oliveira. O pequeno produtor e o crédito rural no contexto da política agrária: o caso do município de Alfredo Marcondes-SP. 2000. Dissertação (Mestrado) - FCT/UNESP, Presidente Prudente, 2000.

PEREIRA, Lucilia Gonçalves Travaglini Carvalho. Uma reflexão sobre o programa nacional de fortalecimento da agricultura familiar - PRONAF. Texto apresentado no Seminário de Desenvolvimento Rural e Políticas Públicas. UNESP- Presidente Prudente - SP. outubro de 2002. 17p (mimeografado)

PETRONE, Pasquale. Notas sobre o sistema de cultura da Baixada do Ribeira, SP. Boletim Paulista de Geografia, São Paulo, n. 39, p.47-63, 1961. 
PINAZZA, Luiz Antonio. Subsídios em profusão. In: AGROANALYSIS - A Revista de negócios da FGV- Instituto Brasileiro de Economia - Centro de Estudos Agrícolas. vol. 19, n.4, abril /1999. p.29.

PINO, Francisco A. et al. (orgs.). Levantamento censitário de unidades de produção agrícola do Estado de São Paulo. São Paulo: IEA/CATI/SAA, 1997. 4v.

POLÍTICA AGRÍCOLA: Novas regras do PRONAF. www.incra.gov.br/fao/diretrizes.htm, 2000.

POULANTZAS, Nicos (dir.). O Estado, o Poder, o Socialismo. $2^{\text {a }}$ ed., Rio de Janeiro: Graal, 1985.

PRADO JR, Caio. A questão agrária no Brasil. 3.ed.. São Paulo: Brasiliense, 1981. 188p. (1 $1^{\text {a }}$ ed. 1979).

Formação do Brasil contemporâneo: Colônia. São Paulo: Brasiliense, 1963.

PRODER/SEBRAE - PROGRAMA DE EMPREGO E RENDA/SEBRAE/FUNDACE. perspectiva para a micro e pequena empresas no desenvolvimento da Região Administrativa de Presidente Prudente. Ribeirão Preto: FUNDACE/USP, 4v., 1998 (Relatório de Pesquisa).

QUEIROZ, Maria Isaura P. de. Bairros rurais paulistas. Revista do Museu Paulista, São Paulo, n.17, p. 63-205, 1967.

O campesinato brasileiro. Petrópolis: Vozes, São Paulo: USP, 1973. 243 p.

.Técnica de gravador e registro da informação viva. In: Variações sobre a técnica de gravador no registro da informação viva. São Paulo: T.A. Queiroz, 1991.

REVISTA GLOBO RURAL. Agricultura Familiar. p. 53-64. Julho/2000. Editora Globo. São Paulo.

REVISTA DA ASSOCIAÇÃO BRASILEIRA DE REFORMA AGRÁRIA - ABRA. Publicação Quadrimestral. Rio Claro. ISSN 0102-1184

REZENDE, G. Do cruzado ao Collor: os planos de estabilização e a agricultura. In: Encontro Nacional de Economia, 18, Brasília, 1990. Anais... Brasília: ANPEC, 1990. p.499-519.

RODRIGUES, Arlete Moysés. A Questão cidade-campo. A Geografia Brasileira e as transformações no Espaço e no trabalho. In: Encontro Nacional de Geógrafos, 11., 1998, Vitória da Conquista. Cadernos de Teses. Vitória da Conquista, Julho, 1998.

Hucitec, 1999.

A natureza do espaço: espaço e tempo; razão e emoção. $3^{\text {a }}$ edição. São Paulo:

SALLUM JÚNIOR, Brasílio. O capitalismo e cafeicultura: Oeste paulista, 1888 - 1930. São Paulo: Duas Cidades, 1982. 
SAMIR, Amin, VERGOPOUlOS, Kostas. A questão agrária e o capitalismo. Rio de Janeiro: Paz e Terra, 1977.

SANCHEZ, Maria Angela D'Incao Maciel. O empresário rural da Alta Sorocabana. 1973. Tese (Doutorado) - Faculdade de Filosofia, Ciências e Letras, Presidente Prudente, 1973.

SANCHEZ, Miguel C., CERON, Antônio O. A atividade pecuária na região de Araçatuba. Boletim de Geografia Teorética, Rio Claro v.19, n.37-8, p. 51-6, 1989.

SANDRONI, Paulo. Questão agrária e campesinato. São Paulo: Polis, 1980.

SANTIAGO, Alberto Alves. Gado Nelore: 100 anos de seleção. São Paulo: Editora dos Criadores, 1987.

SANTOS, Milton. Espaço e método. 4.ed. São Paulo: Nobel, 1997, p.5.

SÃO PAULO (Estado). Secretaria da Agricultura e Abastecimento. Levantamento Censitário de Unidades de Produção Agrícola do Estado de São Paulo - LUPA. São Paulo: SAA/IEA/CATI, 1997. 4v.

SEBRAE - SÃO PAUlO. Associações de Produtores Rurais do Estado de São Paulo. Instituto de Associativismo e Cooperativismo - ICA e Coordenadoria de Assistência Técnica Integral - CATI, 1998.

SHANIN, T. A definição de camponês: conceituações e desconceituações. Novos Estudos CEBRAP, São Paulo: Editora Brasileira de Ciências. n. 26, 1980.

SILVEIRA, Fátima Rotundo da. A recriação capitalista do campesinato: os camponeses na região de Presidente Prudente. 1990. Tese (Doutorado) - F.F.L.C.H./ USP, São Paulo, 1990.

SINGER, P. Desenvolvimento econômico e evolução urbana. São Paulo: Companhia Editora Nacional, 1974. 378 p.

SORJ, B., POMPERMAYER, M. J., CORADINE, O. L. Camponeses e agroindústria; transformação e representação política na avicultura brasileira. Rio de Janeiro: Zahar, 1982. 120 p.

SOUZA, Paulo Renato. A determinação dos salários e do emprego nas economias atrasadas. 1980. 190 p. Tese (Doutorado) - Instituto de Filosofia e Ciências Humanas, Universidade de Campinas, Campinas, 1980.

SOUZA, Sérgio P. Os assentamentos rurais no contexto espacial e sócio-econômico do município de Euclides da Cunha Paulista. 1996. 67 p. (Monografia de Bacharelado) FCT/UNESP, Presidente Prudente, 1996.

SPOSITO, Maria Encarnação Beltrão. O chão arranha o céu: A lógica da (re)produção monopolista da cidade. 1991. Tese (Doutorado) - FFLCH./USP, São Paulo, 1991. 
e GUIMARÃES, Raul Borges (org).Conjuntura Prudente. Presidente Prudente: FCT/UNESP, 1997.

SteVenato, Adriana Salas. A produção de leite na região de Presidente Prudente- SP: o caso da cooperativa de laticínios Vale do Paranapanema (COOLVAP). 2002. Dissertação (mestrado) - Faculdade de Ciências e Tecnologia - UNESP, Presidente Prudente, 2002.

TAVARES DOS SANTOS, José V. Colonos do vinho: estudos sobre a subordinação do trabalho camponês ao capital. São Paulo: HUCITEC, 1978. 172 p.

TARTAGLIA, J. C. (org.). Modernização e desenvolvimento no interior de São Paulo. São Paulo: Ed. UNESP, 1988.

TEIXEIRA, Márcio Antônio. As mudanças agrícolas no Mato Grosso do Sul: o exemplo da grande Dourados. 1988. Tese (Doutorado) - USP, São Paulo, 1988.

TEPICH, J . Marxisme et agriculture: les paysans polonais. Paris: Armand Colin, 1973.

VALVERDE, Orlando. Estudos de geografia agrária brasileira. Petrópolis: Vozes, 1985.

VEIGA, José Eli. Agricultura familiar. In: STÉDILE, João Pedro. A questão agrária hoje. Porto Alegre: Editora da Universidade/UFRGS,1994. p.85,6.

VELHO, Otávio G. Frentes de expansão e estrutura agrária. Rio de Janeiro: Zahar, 1972. $178 \mathrm{p}$.

WAIBEL, Leo. Capítulos de geografia tropical e do Brasil. Rio de Janeiro; IBGE, 1958. $328 \mathrm{p}$.

WANDERLEY, Maria N. B. O camponês: um trabalhador para o capital. Cadernos de Difusão de Tecnologia, Brasília, v. 2, n. 1, p. 13-78, 1985.

A Agricultura familiar no Brasil: um espaço em construção. Reforma Agrária, Campinas, n.2-3, v.25, p.37-57, maio/dezembro. 1995.

WILKINSON, John. O Estado, a agroindústria e a pequena produção. São Paulo: Hucitec, Salvador: CEPA, 1986. 219 p. (Estudos Rurais).

WOORTMANN, E. Herdeiros, parentes e compadres: colonos do Sul e sitiantes do NE. São Paulo: HUCITEC, Brasília: Edunb, 1995.

e WOORTMANN, K. O trabalho da terra. Brasília: Editora UNB, 1997. 
ANEXOS 
ANEXO I 


\section{QUESTÕES DA ENTREVISTA JUNTO AOS AGRICULTORES FAMILIARES DO EDR DE PRESIDENTE PRUDENTE.}

1-Localização da propriedade (município) e bairro rural -

2-O Sr. (a) está a quanto tempo nesta atividade?

3-Qual a origem da propriedade?

4-Com relação ao uso da terra, em percentagem, como se divide a sua propriedade? (culturas, pastagem, inaproveitáveis, outros).

5-Com relação ao sistema de produção agrícola, quais atividades o Sr (a) desenvolve na propriedade? (pecuária, agricultura, fruticultura, horticultura, piscicultura, etc.).

6-Que técnicas e tecnologias o Sr (a) usa na propriedade?

7-Recebe assistência técnica de quem? Com que freqüência?

8-Qual o destino da produção? (consumo próprio, venda direta para o consumidor, para intermediário, para exportação, outro).

9-Que máquinas e equipamentos o Sr (a) tem? Quando adquiriu?

10-Já realizou financiamentos bancários? Quando e para que? Conhece o PRONAF?

11-Contrata empregados? Quando e para qual serviço?

12-Qual a participação da atividade agropecuária na renda familiar? Tem outras fontes de renda?

13-Quantas famílias residem na propriedade?

14-Faz parte de alguma cooperativa, associação, sindicato? O que pensa sobre elas?

15-Na sua opinião que fatores facilitam e/ou dificultam a atividade agrícola?

16-Quais são seus planos com relação ao seu trabalho na agricultura e com o que você produz? E seus filhos, o que pensam sobre continuar nesta mesma atividade?

17-Que serviços o Sr. (a) se utiliza com mais freqüência na cidade sede do município e em P. Prudente? 


\section{TRANSCRIÇÃO DAS ENTREVISTAS}

No. 1 -24/7/01 - produtor me recebeu na casa, depois fomos ver a roça de tomate e algumas benfeitorias do sítio.

1. Sr José - “ Aqui... fais uns vinte anos mais ou menos que nós tamos aqui, antes no município de Regente ali no Bairro Palmitalzinho, nós mesmo trabalhamos de empregados mais ou menos trinta anos num sítio,

2. depois compremos e viemo pra cá, ...........acho que daqui só carregado.

3. A terra é assim, quando...ultimamente plantei tudo capim, mas depois a gente quis plantar uma lavourinha não achô terra por fora, então acabei mexendo aqui mesmo, e acho que nóis tem uns quatro alqueires tombado, e o resto é pastagem, mas só que nóis pega terra fora né...... no passado tava até melhor porque hoje não tá fácil, poque eu acho que o fazendeiro tem até razão porque ele precisa da terra né, a fazendeira (vizinha I) me deu terra este ano e até a gente não ganha, dinheiro até nos fizemos até bastante, mas não ganha por causa dos insumos das coisas que é muito cara né e no fim e não tem preço o que a gente vende..... o custo é muito alto, ué o algodão por exemplo no ano passado foi vendido a 4,5 - 5 US\$ e esse ano saiu 3 e pouco, com algodão tá levando prejuízo, e milho também, o ano passado foi vendido milho até 15 reais a saca e hoje tá 8 mas teve a 7 ....

4. Aqui são vinte cinco hectares, a gente usa assim talvez uma planta e volta o capim outra vez né, hoje tem uns 4 alqueires mexido né, .......plantei tomate depois plantei um pedaço de feijão e vou plantar tomate outra vez em um pedaço que tem de tomate é na fazenda aqui que nóis toma conta, que a dona é de Piracicaba. aqui tudo é aproveitado (a área)

5. ( com relação a conservação)- a gente faz curva de nível, tem irrigação para as lavouras que a gente planta, não todas, usa daí dessa represa quem fez foi a fazenda (que ele toma conta), é noís toma conta da fazenda e ela me dá um pedaço de terra pra mim usefrutá e a gente ocupa a água da represa, disseram que hoje já tá um probrema também esse negócio de água né, porque já tão falando que vão cobrar água da irrigação, eu acho que cada vez vai ficar pior, nóis tamos dentro do padrão( do gasto de energia) a gente pode gastar um pouco mais do que a gente tem gastado

6. Não......... muito pouco a gente usa a Prefeitura e Casa da Lavoura do município, pouco, pouco, inclusive agora tem um agrônomo que até ele,.. a gente conversa com ele, ele a gente conversa com ele, ele fala não, o que precisar a gente vai lá......., mais até....um antes da colheita que depois que virou a colheita vinha um agrônomo aí um dos melhores que tem, também não vou.. citar nomes né, mas só que....... ele vinha um pedaço do dia, dois pedaço de dia na semana e era muito intendido... mas então a gente não procurava ,.......mais intendido em parte, em parte que a gente precisa eles também não entende, por exemplo: se a senhora plantar tomate e chamar um cara desse num......é pior do que nóis, agora ele pruma pastagem, uma coisa e outra ele era bão...., então cada agrônomo eu acho que tem sua...qualidade de...e se especializa nessa coisa. Agora a parte de técnico a gente tem bastante..... o ano passado eu comprei adubo lá ( na associação de palmitalzinho), esse ano já num comprei, nóis tem o técnico...... tem vendedor de adubo, veneno, eles passam aqui.....e se a gente liga pra eles também eles vem ver, eu tenho outro amigo em Regente, um agrônomo também, ele deu cobertura lá no algodão que eu plantei lá em baixo na vizinha, eu acho que de técnico........ assim particular sem ser usar da, da DIRA, da casa da 
lavoura..... eu sei lá... agora, eu nem posso falar nada..... porque um agrônomo na cidade... ele é especializado numa coisa, agora por exemplo, eu tenho tomate se eu chamo ele aqui e ele não entender de tomate eu nem vou chamar porque....então eu já tenho de pegar esse cara que a gente já é acostumada com ele, ou o vizinho que é plantador velho vem dar uma explicação pra gente..... mas hoje a gente tem que usar um agrônomo porque hoje as doenças muda muito né? E o veneno também, a gente vai... mas eu parte de técnico, eu não reclamo.

7. noís só vende para o intermediário, pra cidade só algum poquinho, muito pouco.....tomate.... não até... o trabalho não é, não seria porque a gente vive disso para trabalhar né ?... mas o povo já.... por exemplo tomate .....em Regente entrega, mas entrega muito pouco, por exemplo entrega 100 caixa por semana, a senhora planta uma área grande as vezes vai tirar 300-400 caixas por semana então não consome , então...... a gente apela pro CEASA, comprador lá do CEASA. O pobrema de ter um Box, quem já tem... a gente..., eu vo fala, a gente conversa com eles e o pobrema é que nego... ó.... num paga, num paga. Nós tava conversando com um japoneizinho aí que é plantador de melancia, de roça, tava comentando dos comprador bom dele de melancia que nóis vendia pra eles a 15 ano passado, que num dava pobrema , são de Tupã.....quebrô.... Era nego de carregar, tinha dia de carrega 15 - 20 caminhão de melancia por dia , entregava em São Paulo, no Rio em tudo quanto é lugar, mas quebrô, as vez num recebe também. Isso daí se torna ruim pra gente né porque..., e pra gente entregar direto lá em São Paulo num Box, hum... a senhora num conhece ninguém, num sabe quem é o comprador...piora mais ainda, então a gente escolhe mais ou menos os comprador que a gente acha que é mais ou menos, pra vende.

8. A máquina nóis compramo só de $2^{\mathrm{a}}$. mão, nunca comprei máquina nova, porque é caro né, sei lá num dá pra comprar, não... hoje vai fazer um investimento, a gente investe isso daí prá prantar e depois se..e o pobrema nosso memo vou falar...num é nem a produção, produzir a gente vai produzindo, o pobrema nosso é.... o preço, por exemplo, quando virou o prano aí nem me alembro que dinheiro que era, esse tempo mudo de dinheiro, uma tonelada de adubo era 280 num sei se era urv ou cruzado novo essas coisas, depois caiu aquele, era pra ela voltar mais ou menos uns cento e poucos reais, mas ela ficou uns 260 reais de hoje, hoje ela está 550-600 reais, e o preço.... pra vender o preço abaixa. Veneno memo que nóis pagava 8 reias o litro hoje tá 22-23, o óleo diesel teve uma época que com um litro de leite a senhora comprava um litro de diesel, hoje quase precisa quase 3 litro de leite. O meu leite que é $B$, a turma fala que é um pouco melhor deve estar uns 40 centavos, mas já tem conversa que vai começar a baixa, porque antigamente o nego tirava muito leite nas águas hoje já ta o contrário, nego tá tirando muito mais leite na seca do que nas águas, porque tá tratando, quando nóis logo que passamo pra leite B nóis compromo um resfriador, é meu.

9. Ó financiamento nunca é bom né? Se a gente faz é porque a gente ta precisando de dinheiro pra tocar a lavoura né?, mas eu acho que o pobrema do financiamento tem muita burrocracia pra gente fazer, mas a gente ainda consegue fazer por que a gente sempre pagou certinho o banco né? Tem crédito, e num vou falar que o juro do banco ta comendo o agricultor pela perna que nem nego fala não, num é, é um jurinho , num é baratinho, mas também num é de espanta, o duro nosso é..., na medida que a senhora colhe a lavoura pra vende, porque se tivesse preço a lavoura....e o que o governo qué é isso mesmo, ele qué, ele faz a cesta básica em cima de nóis, dá comida pro povo aí... que não trabalha essas coisas né , e não sabe quanto custa, por exemplo 
café, nóis mexe com café também, eu tenho 30.000 pés de café em mais dois sitinho eu nóis temo, o café hoje tá.... brincadeira porque deu , e a gente não é orgulhoso, mas se fosse um cara meio assim falava larga essa porcaria prá lá, dá pros outro, por que não compensa, e não tem expectativa de melhora não, e agora ta formado o café, pra abandonar agora o prejuízo dobra e pra continuar agora num sei o que vai acontecer mas nóis vamo continuar, ainda tava comentando hoje cedo com um amigo que veio aí em 80, o vizinho meu aí se eu não me engano comprou uma camioneta 4000 zerada com 100 saca de café, hoje pra senhora comprar uma camioneta zerada dessa aí precisa uns 1400-1500 saco de café,um amigo meu tirou uma paraty com 60 saca de café em coco, não é beneficiado não, e hoje a senhora não compra os pneu de uma Paraty com 60 saco, o poder de compra ficou muito defasado, o café mesmo Deus me livre, e acho que não tem expectativa de melhora não, porque nego fala, se der uma geada melhora, mas o Brasil aqui, o plantio de café aqui no Brasil...já ta... tem muito, mas os outro país de fora já ta produzindo muito, e essa política nossa do governo também exporta, exporta, estoca, mas que eu vou fala prá senhora, que num é fácil num é aqui todo mundo trabalha , as muié ajuda.....o juro do PRONAF é 4,5 ao ano não significa nada, num é um negocio ruim, o problema nosso só é o preço do produto, por que produzir nóis produz.

10. nóis trabalha com gente direto, e hoje o medo da gente, a senhora trabalha com empregado, bóia-fria por exemplo, 4-5-6 meses, que nem a gente trabalhou esse ano passado, teve uns caras que trabalhou quase um ano, agora eles saíram porque a gente vai começar a coiê café eles num sabe muito mexer com café, foram colher tomate que ganha mais que trabalhar por dia, mas as vezes tem nego que trabalha 90 dias e depois chama a senhora no departamento e hoje a facada é grande com esse negócio, porque a juíza num quer nem saber, registrar a gente num tem condição de registrar, e se num registrar ce já viu, corre esse risco, porque se ele chamar a gente no departamento ce precisa vender o sítio pra pagar. A gente conhece o pessoal, nós buscamos, a gente pega o caminhão aí nós buscamo, pega às sete e larga às cinco, cum hora de almoço, de segunda a sábado né? das veiz a gente no sábado vai mexer com outras coisas né?, talvez a gente dispensa eles né?, mas é.... a semana inteira. [ pergunto quantas pessoas são mais ou menos]o ano passado nos mexemo com uns 40 alqueires de lavoura, entre milho, algodão, feijão, café, nos tinha 4 peão trabalhando direto e nos somos mais em 4, 8, agora na colheita então, por exemplo na colheita do algodão tinha mais de 100 pessoa na roça, mais aí é negócio de 15-20 dia né? pra carpina e fazer muito serviçinho é por dia , agora prá colheita é tudo por empreita, algodão é por tanto por arroba, então... prá arrancar é por metro.... lá na cidade ele trabalha no banco ele só vai fazer aquilo, se é professor só vai fazer aquilo, então sabe no sítio não, hoje tá carpindo café, amanhã tá carpindo tomate, depois de amanhã talvez tá roçando feijão.

11. Uma das fonte de renda que a gente tem memo de mensalidade mais ou menos, é só o leite, porque a roça é..... só na colheita,...... [ pergunto se dá pra guardar algum dinheiro].... guarda dinheiro... não, não. Médico , nóis pela cooperativa, nóis paga UNIMED pra todo mundo, a gente das vezes tem de arrumar dinheiro pra toca, a agricultura num ta si pagando ela mesma, num ta, agora a senhora podia fazer uma pergunta porque num pára, agora aqui é 3 família se eu pará... eu acho que o bicho pega se eu corre..... a gente só sabe fazê isso daqui então vamo arriscando até um dia vamo perde o que tem ou vamo dá uma acertada em alguma coisa que a gente tenha 
ou dá uma equilibrada, mas que a situação é......isso da gente sobrevive, isso eu acho bom porque a gente tem fartura de tudo, qué dize aqui ninguém tem luxo di nada, de roupa boa, de sapato, vai meio de qualquer jeito né?, agora....mas eu acho que quem tem condições de comprar né?.... é um gosto né?....

12. 3 família, eu, meu irmão e um filho casado.

13. A parte da cooperativa a gente nem.... pode falar nada, porque.... a gente não precisa não, dela por exemplo, precisa assim pra entregar o leite né, o remédio lá é..., o preço de lá é que nem nos outro lugares, a senhora vê a turma lá mete muito o pau, fala mau, mas eu num tenho muito o que fala, porque nunca cheguei lá e fala eu precisei daquilo e me negar, eu acho que pra mim.... o leite tem vez que o nego trabalha no prejuízo, e o lucro é muito poco, porque se uma garrafinha dágua custa 1 real o litro de leite até outro dia ele era vendida por vinte centavos, vinte cinco...., mas agora eu vou falar uma coisa pra senhora o melhor leite que existe é

aquele de plástico, o leite $\mathrm{B}$, o leite de caixinha eles põe até formol dentro pra conservar, o leite é uma porcaria que azeda a tôa, agora o leite, algum leite a caixinha só é tetapark[tetrapak] que fabrica né?, então ela custa 33 centavo pro leite, pra nóis aqui o melhor leite[ a cooperativa paga] 40 centavos mais ou menos, eles nem faiz mais lá [sobre reuniões com produtores], antigamente, toda semana, cada 15 dias, tinha uma reunião, tinha isso, aquilo outro, cabô isso tudo, se eles faiz eles faiz entre eles, só o conselho...nóis aqui num é convidado prá nada, e outra coisa que eu vou falá pra senhora, quando o leite tá em falta, parece muito terceiro e oferece até mais do que a senhora tá vendendo , depois que a senhora passou a entregar, passou 2 meses passou 3 eles iguala com o outro preço, ou até piora com a cooperativa, tem muita gente que mete o pau, mas a cooperativa paga, a senhora pode até gastar 0 dinheiro[antes] eles pagam..., essa vantagem tem, a lojinha quando era no centro era mais fácil, mas agora mudou.... compro mais em Prudente ,a gente pega alguma coisa lá também, por que em Regente também num tem quase nada né? então a gente sempre faz negócio de trator, peça, a gente faz em Prudente, vai daí e pega tudo lá.

14 . Sei lá ..... a gente dificulta de pegá terra prá plantar, porque a gente num tem a...terra, porque a gente quer plantar mais, pra vê se tem uma renda melhor, aí se torna difícil prá pegar terra, não é fácil pegar , e outra das vezes tem longe mais nóis num pode sair longe trabalhar , num pode deslocá 20-30 km pra trabalhar, daí o óleo diesel pesa mais , a gasolina... vem tudo né? e aqui por esse ano a vizinha me deu um pedaço de terra pra nóis lá, eu fiquei contente, até eu preciso conversar com ela porque eu fiquei de jogar semente lá, pra ver se ela vai me dar algum pedaço ainda ou não.

OBS: a fita acabou e eu não notei, assim perdi as respostas a mais duas perguntas que faltavam! 
No. 2 - Município Anhumas- Bairro Água do Cedro-26/6/01 [ irmãos que tem um sítio junto], os três responderam juntos as perguntas feitas por mim, me acompanhou até a roça de melancia (arrendada) o pai, Sr. Pedro.

1. desde que nascemo, começou a trabalha com 8 anos, 30 anos já, ia na escola cedo né?, vinha na escolinha, e na parte da tarde...... depois num tinha $4^{\circ}$. ano nóis fomo pra casa do avô na Anhumas pra fazer $4^{\circ}$. ano.

2. É herança, pegô do avô, veio de Minas, Guaxupé, toda a fazenda acho... parece que era 200 arqueires, dividiu entre os herdeiros, 42 hectares pra cada um , nóis vem trabaiando nesta área desde então, desde mocinho..... fais uns 13 anos que nóis começo a arrendar terra pra fora de primeiro nóis só trabaiava lá, no café, que foi prantado, é eu e meu pai que prantou café , era mato ali, pegou tudo em mato.......era só café aí nóis foi acabando com o café e nóis fomo mexendo com o gado, formando[pasto] e tirando leite, depois lá cabou com o café, lavoura lá num toca só tem gado lá, o leite vende prá cooperativa, há uns 15 a 20 anos sempre pra cooperativa,..... o gado foi comprano aos poucos, cruzado né, foi compro um boi puro pra gente ir fazendo o gado né? prô gado de leite foi muito pouco comprado né? por que vai criando...... vai apurando aos poucos né?

3. Agora lá[nós estávamos em área de arrendamento, fora da propriedade]é tudo pasto né? mais tem a reserva né?, 3 alqueires, o pasto é de brizantão, manbaça, vai aparecendo capim novo né?, vai mudando né?, a gente vai experimentando o caminho todo né?, lá num tem cultura, agora não. [sobre o arrendamento] desde 87, né Cícero? 87....prá acha até que é fácil, arrenda terra não é difícil, o pessoal já conhece e pelo tipo de procura também [o uso da] a terra é... rápido né?, num fica 2-3 anos, num ocupa muito, que nem nóis tá arrendando aqui, quando fôr no fim no ano já entregô, as vezes pra faze um contrato a gente precisa faze...inscrição, abrir inscrição, talão de nota, a gente obriga fazer um contrato pra faze inscrição [ depois que colherem a melancia] aqui nóis vamo deixa tudo preparado, ajuda ele a prepara a terra, a tomba a terra,....... depende do acordo....que é feito na hora né? pela cultura que a gente pranta é uma veiz só, geralmente é desse tipo aqui o acordo.

4. [lá na propriedade só tem pecuária de leite e fora ......] lá antigamente era café , hoje num tem mais nada.

5. Faz análise, só trabalha em cima de uma análise, faz calagem, curva de nível, usa irrigação.

6. Aí é o pobrema.....num tem..........assistência técnica num tem, essas casa que vende insumo aí tem agrônomo né?, num serve muito de base, né? porque eles tem interesse também em venda né? é complicado né?...num sabe se eles ta falando a verdade ou se quer vendê o produtos deles né?[ e os técnicos da casa da Agricultura?] agora que esse ano que começou lá né?, que tem em Anhumas, acho que era mais fraco, acho que era por causa do prefeito que num dava muito apoio pra agricultura,....... por que aí ele ficou 20 anos, nos num elegia ele, nóis votava pra num elege ele mais os outro votava né?...[risos]...aí .....nóis nunca quis, os otros é qui quiria. Agora mudô, tem um agrônomo.... porque agora é tudo....tem uma associação aí, a partir de maio, fez 2-3 meses, [e a iniciativa foi de quem?] é tudo um agrônomo, ele é de Prudente, atuava em Regente, é Wesley. Acho que na Anhumas é por conta da prefeitura, mas um agrônomo só é pouco, 10-12 ano que a gente mexe com isso, a gente já tem uma experiência também, já pra saber se o cara ta empurrando, temo prantado mais melancia só, pranta feijão também né?, abóbora, pouca coisa..... 
7. pro intermediário né, tudo pro intermediário, as vezes põe direto mas é muito difícil né? a maior parte do movimento da gente é pro intemediário,[ estão satisfeitos com esse tipo....], contente não né? é meio difícil pra gente mesmo vender porque mercadoria nóis num tem, num produz, pra vende o ano inteiro por exemplo, então você num pode contrata lá no CEASA o ano inteiro então, [a associação] eles estão começando agora né?, eles tão vendo uns negócio aí mais tá com 60 dias né? ainda ta começando a caminha né?, começando agora né? agora vamo vê né quanto tempo vai........5 real por mês, nóis só ta em dois associado né eu entrei mais só ta eu e ele associado, lá ta com 42 associado. [e o preço?] depende do dia , é o mercado, é o preço é o intermediário que vem, fala ta tanto, porque a gente nunca dá preço nas coisas da gente né?, ce liga pra 2-3, ce ta meio por dentro né? mais ou menos ce sabe qual é o preço né?, liga pra 2-3, sabe mais ou menos quem pranto, quem ta colhendo, sempre sabe também o preço do CEASA, as vezes liga né?, [e pra receber?] aí é que ta o pobrema né as vezes 30-40-50 dias né?, as vezes , tem muito que dá calote né?, até inclusive nóis num ta tendo muito ........, ta tendo sorte nesta parte de receber, num tamo em área muito grande, a gente tira muita informação, as vezes se o cara ta meio pobrema, quando escuta fala, ta ruim corre né?, os amigo que pranta a gente pega liga pros amigo e..... [pra onde é vendido?] geralmente eles leva pra São Paulo, pro Sul, nóis vende muito pro Sul aqui, nosso mercado forte mesmo é aqui pro Sul, Paraná......aqui. melancia é semente e muda, nóis ta prantano semente, a muda é mais rápido , mais depois que ce pranto na terra ela demora mais, ela dá uma amarrada, nóis acha melhor pranta na semente assim, porque se ela num nasce no clima assim, as vezes ce tira da estufa, na estufa é um clima né?, as vezes um vento frio que nem hoje cedo..... [ de quem compra a semente]nóis liga pra sabe o preço tudinho como que esta, o mais barato..... Prudente, Tupã, semente importada, dos Estados Unidos, [o Brasil não produz?], produz, tem mais não é a híbrida, se for comprar o nosso aqui [o preço] é menos da metade, o que ce paga na latinha daqui, de $1 \mathrm{~kg}$, é o preço de $100 \mathrm{~g}$ da importada, 138 real o preço da importada, [então a produção é melhor?], aí também depende do clima......[qual é o ciclo da melancia?], uns 90 dias né?.....depende dá época, se pranta agora (julho) ela vai demorar um pouco, se pranta em outubro ela, tem mais sol , o dia é mais comprido né? em torno de 70-90 dias, [e a semente da abóbora , cabotchã, são as mesmas condições, né?], o prazo[ para pagar a semente] é quanto o cara aguenda né, cobra juro 3,5\% né. Aqui é 20 hectare, aqui nóis num tamo pagando nada, só jogou calcário, é uma troca, pra reforma, mata a grama véia, pra jogar de capim novo.

8. trator, pulverizador, são próprios, compradas em 90, aquele lá foi comprado novo [o trator], tem irrigação 88 , tá boa, é motor....faz retífica né?, é so cuidar né? só usa quando faiz seca memo né?

9. foi financiado, esse aqui é 94, compro usado né?,,..... o financiamento compensou?] aquele lá, quando compro aquele lá pagomo 3 vezes, o valor dele, nóis compro no prano [ plano Collor] num preço né?, depois estourou o juro, o juro era....., quando nóis paguemo a úrtima parcela, a úrtima parcela era o valor do trator no mercado, toda veiz que nóis ia paga a prestação, comprava ele, nóis pago 3 vezes, se não paga...., aí tinha propriedade hipotecada, tinha gado na hipoteca......num tem jeito é corda no pescoço, [ e outras coisas vocês financiaram?] nóis já feiz já financiamento, mas ultimamente....., ta com uns 2-3 anos né? que nóis num mexe mais, trabalhamos com o Banespa, depois com o Banco Brasil, de Regente[Feijó]. Foi para melancia, pra feijão, 
[que ano foi?] esses anos pra trais, de 99 pra trais, sempre demo conta, teve época que num deu não, o que perdeu nóis renegociou, prolongou a dívida. [Fazem seguro?] tinha de primeiro, agora num tem mais né? pra melancia num tem mais [para outras coisas tem?], só tem pra feijão né?, só COGESP fais né?, feijão e milho né? pra tomate fais também, né?, [e o PRONAF, já usaram ...], meu pai usou né? [ vocês acham que esses financiamentos ajudam?] o duro...., o pobrema do financiamento é a burocracia que é grande né?, ce vai faze um financiamento é?..... eles pede tudo..., quem fais é o Banco do Brasil, e o Banco do Brasil é uma burocracia violenta, e geralmente quando ce vai pedir o financiamento ce tem que ta zerado, limpinho, sem nada né? se tiver alguma coisa pendente já num sai, então as vezes você tem um pouco de dinheiro, acaba muito melhor você pagar 3\% lá na firma, do que ficar aí.... 60 dias aí pra pegar o financiamento, você tem que pegar o ITR do proprietário, pra trás 5 anos do ITR dele né?, [ quem é de vocês que faz essa parte?], ele cuida da roça, ele cuida de Banco, eu mais na parte de venda, no fim cada um dá uma mão né?, dá uma ajuda, dá idéia, divide um pouco pra num ficar tudo...., realmente cada um pega uma coisa, tem cunhecimento num lugar outro no outro, né?

10. [ Vocês contratam empregados?] pra colheita né? [quantas nessa área de 20 hectares?] mais ou menos uns 5, pra prantar, depois ficam 5 pra molhar, 5 trabalhando na área, pra colher aí precisa mais gente, conforme aperta né?, precisa umas 15 pessoas né? aí aperta aí, umas $10-20$, hoje mesmo precisamo de uns 3 a mais, de Anhumas, a gente mesmo conhece, eu tenho conhecimento[um dos irmãos] tem um rapaz que trabaia com nóis mais tempo que tem telefone, daí a gente liga lá e já combina né, a gente fala arruma mais amanhã, [já tiveram problemas trabalhistas ?] Não, isso não, porque geralmente as vezes eles trabaia pouco tempo, 10 dias, 5 dias, num trabaia, já para....... gente dispensa né?, então num trabaia muito tempo né? se ficar muito tempo é pobrema né?, meu primo toca roça, vorta e meia nóis troca, faz um rodízio, num fica muito tempo, porque se trabaia muito tem pobrema, Anhuma num ta tendo desses pobrema porque Anhumas ta tendo muito serviço, a cidade é muito pequena, faz falta gente, falta mão de obra, todo mundo queima ali né?, o cara levo o patrão no departamento, os outro fica sabendo já queima ele, ao mesmo tempo a gente precisa dessa mão de obra também, é uma coisa que a gente tem que conversar né? tem que correr esse risco também né? mais a gente procura sempre trabaia também mais na parte de amigo né ? tem dia que trabaia um pouco mais tarde né? [como vocês pagam?] Por dia , agora tamo pagando 10 real o dia. Se ele trabaia até 3-4 hora eu pago o dia, né?.

11. Tudo [ a renda familiar ] vem da agricultura e do leite, eu tenho um menino que já ta fora, 17 anos, mora com avó dele lá em Anhumas, trabalha lá num escritório.... a mãe e o pai são aposentados.

12. 4 famílias, com meu pai aí.

13. meu pai é associado na cooperativa de leite né?, e eu e ele aqui, nóis somos da associação em Anhumas, começamo a montar agora, falei pra ela aí que faz uns 60 dias que....pra mim nóis num fomo criado pra associção não né, nos num fomo criado assim. Esse povo que vem de outro país né, da Europa né, esse povo já foi criado com uma mentalidade né , que nem do sul né, essa mistura de raça, é , tem outra cabeça, [as pessoas pensam diferente?], uns que num concorda, outro que aproveita, associação tem que ser um negócio sério né.....tudo isso, na cooperativa o povo se acomodou, ninguém tira eles de lá,ta do jeito que eles qué [ sobre a diretoria da cooperativa ], o 
produtor num liga ué, o associado num liga né? eles vai deitando e rolando, o pobrema da cooperativa é assim, ali eles...a maior parte ali é de produtor de 100 litros pra baixo né?, eu participei muito de reunião ali né?, a grande porcentagem né?, então aqueles grande eles manipula, traiz vamo supo assim na barra da saia......né? e os pequeno vai atrás né?, num tem voz ativa né? os cara vai e tira 50 litro de leite né? e eu vou perder o que vai lá né?.......[vocês tem resfriador?] não, por enquanto não, [ a cooperativa deu prazo até dezembro de 2000 para os produtores substituírem latões ] por porque quem tira 50 litro....num tem condições né? não paga o resfriador né? acho que nóis memo né, se continuar.... for te que te resfriador, nóis vai ter que para aqui né?, ou aumenta ou larga, prá aumenta é difícil né?, a gente num vê futuro no leite, pra investir no leite......

14. O mais difícil é..... eu acho que é o preço de insumo, o mais que atrapalha né ? num tem como fugir dele, há 5-6 anos atrás se vende o preço que ce vende hoje né? só que a tonelada de adubo há 5-6 anos, dobrou praticamente, era 180 real, quando entrou o prano depois, era 180 uma tonelada, hoje é 500 real, ce vendia um kilo de melancia hoje vende ao mesmo preço, [ e o combustível] era 0.33 centavo o diesel, agora é 0.80 , e você ta vendendo o produto mesmo preço, o preço pra venda é o mesmo, e num é só melancia não , feijão, milho, e tudo....por aí, isso que a gente ta vendendo né, acho que todos os agricultor vai responder essa mesma pergunta se você for procurar.

15. A gente fazendo o que a gente aprendeu já ta difícil né? a gente tenta se aperfeiçoar né? melhorar né? pra competir com o mercado, a demanda né?, o que a gente ta tentando fazer já do ano passado, é fazer cultura né? pra colher pelo menos de cada 90 dias colhe uma cultura, esse ano nóis já colhemo tomate, cabemo de colher, ainda tem um resto pra colher de cabotchã né?, arranquemo feijão né? agora a gente que colher essa melancia, [ fazem um planejamento um ano antes?] é , então a gente...., nóis começo desde o ano passado né?, nóis pranto um pedaçinho de tomate [ciclo de 90 dias] lá no sítio, então a gente começo janeiro né?, depois já começo prepara, nóis vamo prepara outra área pra pranta feijão e abóbora, pranto em março, cabemo de coiê o tomate e reprantemo abóbora, a abóbora também é uns 90 dias,[ e agora] nóis tamo mexendo com a melancia, depois nóis ta querendo pranta uma área que nóis ta querendo reforma lá no sítio nosso, pra pranta lá em setembro... pra pranta melancia também pra coiê no fim do ano, em novembro...no Natal, a gente pensa só de ficar aí dezembro....e janeiro, janeiro a gente já começa a mexer com tomate né?, parado mesmo, praticamente só o mês de dezembro né?, ainda do dia 15 em diante, porque hoje em dia num pode ficar parado muito tempo, né?, porque dinheiro a gente gasta todo dia, a gente diminui um pouco as áreas né? e vai prantando né?.[vende pra quem?] intermediário ,CEASA né?, vamo ligando, vendo o povo que paga né? tamo até levando sorte, a gente cuido muito né?, se preocupou muito com esse lado, sabe hoje em dia se os cara vim aqui compra uma melancia aqui, ele vai chega aqui antes de carregar... a turma vai fala assim: vai se a vista ou a cheque, se for cheque... vou consulta, a gente consulta né?, na hora né?, o senhor carregou aonde? Ah, eu carreguei de fulano de tal, ele tem a lista ali na camionete com tudo o nome de plantador de melancia né?, aí a gente tem contato no sul, aí tem os cara lá que a gente liga lá,[ vocês já levaram prejuízo?], já, já levamos, e os cara de lá ligam aqui também. A gente já conseguiu eliminar uma boa parte..... eu procuro mais assim, por exemplo, se eu tiver 10 área de melancia pra vende, eu procuro vender pra 10 pessoas, por que se 2 me der calote sobra 8 , já vindimo até 40 viagem de melancia, uma roça inteira pra 
1 pessoa só né ?, mas hoje num faço mais , as vezes o cara sofre um acidente........hoje o cara ta bom, por exemplo, nóis vendeu melancia quando? dezembro né?, nóis vamo vende melancia agora em novembro, outubro né? e se o cara num....... e o dinheiro? Dá pra guardar alguma parte? Ta tudo investido? É tudo pra paga as contas?] Dá nada, num sobra, ta que nem eu falei né ? nóis temo um financiamento prolongado, uma conta aí, temo que programa memo pra paga, a gente prolongo tarde, e procurando trabai,, que nem agora, comprando á vista, pra num financia, pra ninguém tira né?, ficar mais barato né? num deixa remontar né, a margem é poça então a gente....tem que tirar né ce vai compra... ce paga $3 \%$ na firma né? mais né?, se você for compra á vista né eles dão até $5 \%, 3$ que você ia paga com 5 dá 8 né? o investimento aqui é alto , mais de 30 mil real, [ numa boa safra vocês ganham quanto?], sobra né, dá paga o banco, e pras despesa da casa,né?,[ você tem plano de previdência médica?], só o pai e a mãe pela cooperativa, o resto paga particular, nos temo seguro,de vida pelo banco. Nóis tava conversando, porque a idade vai chegando né?, tem que pensa né?, apareceu esse plano de previdência rural mais paro de fala né? era muito caro num era?...[vocês já ouviram falar sobre a cobrança pela água que é usada no campo?], já ouvi fala parece que vai se votado agora né?, já ouvi fala isso, mais se vai.... um dos pobrema grande de quem mexe com irrigação é esse pobrema do meio ambiente aí, né?, se você põe um motor na beira do corgo (córrego) o florestal já vem em cima, né? você se vai cercar uma água ali tem que por saco de areia, num pode fechar né?, agora pra fazer, dizem, prá financiar uma lavoura irrigada tem que ir na florestal pega um atestado né? pra ver se eles autoriza, pega mais dinheiro, a hora que começa a irrigação já começa a florestal andar por aí, o ano passado eles tava direto aí oiando direto a nossa roça aí, voando aí, o aviãozinho passando né, pra nóis num falaram nada , mas pro dono da fazenda falaram que tinha de modera a irrigação, aonde estava o motor?, como é que estava , se tava entrancado o rio?, eles desceram pra ir lá, ontem eu e o filho do dono aí tava conversando aí, ele falo: acho que devia sair um plano aí pela associação que chegasse até o governo, as autoridade que obrigasse as propriedade a fazer um reflorestamento na margem do rio, de uns 100 metros da margem, então ele falo, agora num adianta vim aprica uma murta se o dinheiro vai pra lá e some, o meio ambiente ta se acabando...... o pobrema de agrotóxico aí também, que eles vão pega também os vasilhame vazio né? eu acho que se reflorestasse as marge do rio, cada proprietário já ia melhorar, a gente tava ali olhando as marge, se você descer daquele morro ali, ali tem um rio que é reflorestado, ce precisa ver como é que a água é dentro então num... aumenta muito a água, daqui 30 ano nóis ia ter um rio tranqüilo aí, agora num adianta.... ce fais um serviço aí, cortam a água, o cara vem aí e aprica 1500 real de multa, agora vai o dinheiro e some e o meio ambiente cada veis acabando mais né?, ta mal usado, o pobrema num é multar é conscientiza o cara a num...né? e o próprio governo.......aqui memo o dono da fazenda, ele fez um bebedouro lá em cima e levou uma multa de 1500 real, ou ele pagava ou ele prantava 150 muda de árvore, aí ele falo não, consciente, eu vo pranta árvore, eu vo morrer, eu largo, por que se eu der 1500 reais vai sumir né?, só que ele vai ter o trabalho de cerca, ficar cuidando das árvores, mas nem todo mundo pensa assim né? vai lá e paga os 1500 reais e fica livre. [e a energia?] veio pra economizar, mais nóis tamo dentro do gasto né?

16. Prudente é mais insumo né? uma máquina, peça, conserto, retífica...é tudo Prudente, semente.... [ e coisa pra casa?]é Regente, mais perto, mais conhecimento né? 
No.3 - 27/7 2001- produtor - Planta batata doce em terra arrendada. Me recebeu em casa.

1. Há uns 25 anos que eu trabalho na agricultura.

2. Antes eu trabalhava com meu pai, depois eu passei a trabalha por conta né? casei tenho minha família.[ seu pai está aqui há quanto tempo, veio da onde?] 34 anos, meu pai é nascido em Minas, aí depois meu vô se estabeleceu aqui na região, daí ele foi ficando e trabalhou conseguiu compra esse sítio e criou toda família aqui, sempre aqui na região de Prudente, sempre viveu da agricultura, o que ele tem hoje foi tudo da agricultura, criou os filhos agora se aposentou......., [ você tem terra sua?] moro na propriedade do meu pai, esse ano consegui comprá uma, fui juntando, juntando e consegui comprar uma propriedade, 10 alqueires, agora vou passá a planta nela .

3. a partir desse ano vou planta nela pra fugir da renda, por que num tem como você paga a renda, quer dizer, as vezes até fica interessante você paga a renda, só que você não consegue.... a terra pra planta ou nas condições que você precisa né? vou arrendar a terra mais só pra tal período né, ou pra você planta tal coisa, ou você tem que fazer uma coisa que.... fica sujeito ao que o dono a terra qué, impõe condições que as vezes num tem como você cumprir, então para isso cada um vai ter que ter sua propriedade, [ e essa área que você comprou?] a essa propriedade é o seguinte, era do meu vô, aí meu vô morreu ficou para uso fruto da minha vó, e agora minha vó também morreu e aí ficou para os filhos, 2 desses filhos moram em São Paulo, então eles não tem interesse em ficar aqui, então eles venderam, eu comprei pra ficar junto, pra dar volume, paguei pra eles e agora vou passar a plantar, é aqui pertinho, no município de Caiabu, há uns $9 \mathrm{~km}$, então eu to tendo assim uma esperança que vai ser melhor, vou fugir da renda né?, vou plantar no que é meu, não vou depender de prazo né? por que você pega a terra, o cara, a pessoa quer um prazo né? ele fala: vou te arrumar a terra mais até tal época né?, as vezes fica até inviável, você pega na esperança de fazer 2 plantas, por exemplo, vou fazer duas plantas então, vai ficar mais barato né? vou fazer 2 planta né? e depois por causa do tempo né?, ou alguma coisa assim que acontece nesse meio de tempo você não consegue planta, só planta 1 , aí perde tempo, você investiu achando que você vai tirar duas planta, aí depois por causa do tempo você consegue tirar uma só e o cara não, o cara também precisa da terra, agora fica difícil, num tem incentivo.

4. [ você tira leite, tem gado?] Não. Pra mexer com leite e gado você tem que ter muita terra, tem que se uma propriedade grande pra você conseguir diversificar, aqui só lavoura, antigamente meu pai plantava um alqueire de feijão, plantava um alqueire de milho né?, então usava isso quase só para subsistência e vendia o que excedia né?, agora hoje[ a despesa] vem, o telefone que é mensal, energia que é mensal, a água que é mensal, todo mundo tem um carro, então quer dizer que você tem uma despesa muito grande mensal, então você tem que produzir bastante pra você conseguir sobreviver a esse período que você não tem, né?, se você planta um alqueire você colhe, consegue viver 2 meses e depois? Então ce tem que plantar bastante, pra se você ficar aí 3 meses sem produzir nada, você conseguir pagar as contas, que hoje é mensal né?

5. A gente, até que tem....... preocupação com técnicas e tecnologias]só que fica muito caro e é a que tem que correr atrás disso né?, ninguém vem aqui oferecer ou... o governo fala lá, muito bonito, só que na prática mesmo isso não existe né?, e se existe na fica muito caro né? então você, se você for querer investir hoje, você acaba não tendo o retorno disso, você não consegue né?, se você for investir e fazer tudo mesmo, então é a gente mesmo que tem que correr atrás, de melhorar a produção da gente né? essa batata que a gente vem plantando num é.... a gente já sabe que a rama já 
degenerou, que já num é a mesma coisa né? só que ninguém vem aqui oferecer estudo, a UNOESTE, essa semana passada o Secretário da Agricultura de Prudente teve aqui e comentou que disse que tem um estudo que já constataram.....nunca veio mostra, e a gente sabe disso né?, a gente tem conhecimento disso, só que fica muito caro né? como que você vai conseguir fazer um melhoramento, então agora já falaram que tem uma pesquisa lá que realmente já foi constatado que a nossa rama já degenerou, e que a produção dela hoje é em $60 \%$, que junto com essa rama que a gente ta usando junto com ela já tem 3-4 variedade misturada, então foi misturando, foi passando e foi ficando tudo misturada, só que falaram, agora realmente não sei se vai ter, se eles vão produzir essa rama né? porque é aquela coisa você tem que fazer acontecer e aí os governante vão ver, fala não realmente a batata é rentável, é aí que eles vem atrás, nos fizemo tudo isso até hoje, nos fomo plantando e dali foi aumentando, foi passando de 10 pra 50 e todo mundo plantando e agora é que eles foram ver que realmente a batata é interessante, agora é que eles vieram atrás de oferecer, se eles tivessem oferecido isso há mais tempo atrás, num teria chegado aonde chegou né? porque o que aconteceu, o cara plantava 1 alqueire, de 1 passou pra 2 , de 2 passou pra 3, ele foi aumentando a quantidade de área plantada pra pode dá lucro.

6. Não num tem, esse ano que o prefeito Agripino implantou lá na Secretaria da agricultura, tem agrônomo né, e ofereceu e falou que ta a disposição de qualquer produtor que quiser ir lá num paga nada, mas só que o pessoal num vai atrás disso, o pessoal já ficou meio discrente, já ficou discrente com isso, que num...acha que tem que a gente mesmo fazer, chega lá é muita dificuldade, e aí tem que... a adubação tem que ser muito grande, então vai ficar muito caro e fica inviável e acaba que ninguém vai seguir isso não, não vai aproveitar, a gente vai no Sakita, chega e fala , a minha roça ta com isso e isso e ele fala ah joga 500 kilo disso e passa 200 litro daquilo, fica muito caro né? acaba que num compensa né ? porque o que precisa pra agricultura é preço né? tem que ter preço, tem que ter lugar pra voce vender, agora o que adianta você ter uma produção lá enorme lá, e num ter pra quem vender, igual nóis plantamo uma lavoura de berinjela, disse que era bom, incentivou, num sei o que, ta plantamo, deu berinjela grandona lá bonita né?, mas na hora de vende num tinha pra quem vende, num compensava , eu mandei pra São Paulo, pra você ter uma idéia, veio a fatura negativa, pra eu pagar, eu mandei a caixa de berinjela, tipo a caixa , com o frete, a comissão do cara lá pra vende, em vez de vir positivo, eu ainda tive que devolve, veio a fatura negativa, aí eu falei vamo erradica, a gente gradeou, vai deixar? Né? Então contece muito disso, na nossa atividade acontece muito disso de você planta e não ter pra quem vender.

7. Vende pra intermediário, pro CEASA e daí o CEASA repassa né? por que é uma corrente, infelizmente é isso nosso país é isso, precisa disso né? por que se não tiver .....tem que ter o produtor, do produtor tem que ter um que atravessa ele aqui na roça pra joga no mercado, do mercado atravessa pra joga ele no consumidor por que infelizmente é isso, num tem como você......se for querer viver sozinho num consegue, isso aí ce fala mais aí o cara vai planta e vai vende lá na frente, num consegue dar um.... ele num consegue....continuar..., o cara vai plantar uma estufa de cenoura, vai vender pro CARREFOUR, o CARREFOUR quer um contrato de que o ele vai fornecer o ano inteiro né? , agora o cara vai lá , vai fornecer uma safra 10-20 caixa agora, umas 100 caixa que seja, e daí cabo, vai o CARREFOUR corre atrás de outro, eles num querem isso, eles querem o cara que forneça o ano inteiro, se bem que pra isso eles vai 
paga mais caro num interessa, eles querem comodidade. Facilidade né? o ano inteiro vai ter cenoura, num interessa da onde que vai vir, se chove ou faça sol, se ta barato se ta caro, vai te,então é isso que eles querem né? e a roça num consegue fazer isso, agora pra fazer isso, acho que deveria ter que ter incentivo, acho que deveria ter uma cooperativa, pra pode fazer isso, só que infelizmente o povo é muito desunido, num vai atrás disso. A semana passada eles vieram fazer uma associação de produtores, aí a prefeitura vai doar, fazer o que eles chamam de patrulha agrícola, vai doar um trator com todos os implementos e vai ter uma associação, dessa associação vai criar uma diretoria,muito bonito e tal..... mais ninguém foi atrás, chego lá tinha meia dúzia de produtor, já precisa de 25 só para formar a diretoria e acaba que o pessoal num vai atrás e a acaba que o pessoal diz assim: você num quer ser o presidente? Num quero, ce vai lá pra num ganhar nada né?, vou lá ser o presidente pra trabalhar,pra passar raiva, pro cara vim brigar comigo...ah mais o trator ta lá na roça do fulano, porque você num mandou pra mim? Pra num ganha nada, então,daí o pessoal criou essa mentalidade de que é cada um pra si e Deus pra todos, num qué nem sabe, num tem essa não, a associação já morre ali antes de nascer, eu acredito...... eles estão tentando formar... não vai formar e se formar também não vai dar certo, eu acho...... que deveria formar uma associação par todos os distritos né? e ter um pessoal lá da prefeitura ou da universidade pra toma conta, agora se colocar produtor pra tomar conta num vai dar certo,[ mas o produtor não sabe melhor das necessidades que gente de fora?]mas o problema nosso aqui é o seguinte, eu acho que isso até funciona lá no sul, lá , que tem muita propriedade pequena né?, o pessoal vive em cima daquilo ali, agora no nosso caso aqui, o pessoal já partiu tudo pra pecuária, né?, a maioria partiu para a pecuária, e esse cara num quer nem saber, ele tem a máquina dele, ela tem o trator dele, pra que ele vai se envolver na associação pra passa raiva outra disputar 1-2 horas de trator, ele num vai né?, então num funciona, eu acho que tem que vir de cima mesmo né? num tem jeito, igual era, igual tava sendo, a prefeitura tem os tratores e eles comandam, na primeira vez que o trator quebrar que tiver que ratiar essa dívida aí pra paga, nego sai fora, fala não.....o trator num trabalho pra mim né?, a sua roça é maior que a minha, o trator trabalhou mais na sua roça do que na minha, porque que agora eu vou paga o mesmo tanto, né?, eu acho que não funciona, vai dar probrema sim , como já deu antes de começar. [falaram nessa reunião sobre outras coisas como, baratear custos juntos?]...é eles tentam fazer isso, só que isso só funciona, no lugar que tem a vocação agrícola né?, isso aqui poderia ter dado certo a mais tempo atrás, hoje num dá mais, né?, se você vai na Paulista [região ao norte] aqui em Lucélia..... aqueles lugar ali existe, existe associação, existe cooperativa e funciona, porque tem bastante propriedade, então quer dizer, se tem 50-100 se associa, então o preço dele é isso, ele gosta de ver dar certo e depois fazer, Maria vai com as outras né?fica meio desconfiado, a o cara vai fazer aquilo ali vai quebrar a cara, se deu certo né? ali ele entra junto , se deu errado aí ele vai criticar, então pra nós aqui eu acho que num funciona, justamente por isso, por que já esta discrente, quanto tempo que o povo vem trabalhando sozinho, agricultura é isso, o cara faz sozinho, o cara vai lá e.....planta, ele faz a experiência, aí depois que ele fez, aí vem ou criticar ou elogiar né?, ah.. porque o cara plantou e num tem pra quem vender outra hora, aí vem incentivar né?, aí vem a TV Fronteira mostra, nossaaaa a produção ta num sei quanto, ta exportando, ta isso, ta aquilo então quer dizer o cara vem quando dá certo ou errado, num tem um meio termo, eles só vem quando o cara quebra a cara ou quando ele se dá bem. 
8. Eu tenho, meu trator 79, pra você ter uma idéia né?, só que eu tenho vontade de compra um novo né?, essa semana mesmo passou um cara aqui pra vender, 34.000,00 reais, aí juro de $8 \%$ ao ano, é tudo muito fácil né?, mais só que aí o que que adianta você investir numa máquina, se você num tem pra quem vender sua produção.....num sabe o que vai acontecer lá na frente né?, num é igual ao empresário, ele prevê.... a industria dele lá, a produção deles pra daqui 5-10 anos, ele sabe o que vai acontecer, a gente num sabe........aa você compra um trator desse aí 34.000,00 reais......., eu to vendo um monte vendendo [trator]com 4-5 anos de uso pela metade do preço, agora eu vou investir 34.000,00 reais para colocar numa atividade que eu num sei se vai dar certo, num tem nada que vai me dizer que isso vai dar certo, e....então tem que ficar com velhinho mesmo, o 79, então a lavoura está muito sucateada né?, por causa disso, você vai em qualquer propriedade você não acha uma máquina nova, só máquina velha.

9. Num fiz. Já fui até perguntar, e me informar da....., no banco do Brasil, daí você chega lá, ah... não nóis não ta financiando...feijão por exemplo, feijão num ta financiando né?, você tem que ir lá em Machado, aí chega lá em Machado e aquela burocracia, tem que arruma isso, tem que arruma aquilo, tem que pagar seguro, tem que pagar um agrônomo, ce paga $2 \%$ do seu projeto já, o agrônomo só vem aqui uma vez, aí ah....mas tem seguro, só que seguro só cobre vendaval, granizo, quer dizer.....sol não cobre.....então, quer dizer você não tem segurança nenhuma né?, é..... aquela burocracia toda.....então, eu acho que não funciona, e outra você não tem garantia se você vai vender sua produção né?, você vai lá e financia, então vamo supor, você tem uma perspectiva que você vai colher 1000 caixas de batata, então você vai colher 1000 caixas e eles vão te dar 2000 reais, que vai ser 2 reais por caixa, você fala vou vender por 5, pago 2 né? fico com 3......na hora que vai vender......a batata cai para 1,50, já num paga nem o financiamento que você fez, e daí né?, então dá medo, então é melhor você plantar menos e plantar com recurso próprio, por que o governo até que passa isso, ele faz isso que é muito bonito. A semana passada um colega meu tava me falando que o governo solta financiamento, lá pra uma propriedade tipo... por exemplo de 100 alqueires, ele pode pegar um milhão de reais.... mais o banco.... num dá, num dá porque o juro é muito barato, um juro de $8 \%$ ao ano, então o banco num tem é....interesse em emprestar um juro tão barato, então né? o governo acha que o dinheiro veio, acha que o dinheiro foi emprestado, eles [os bancos] faz as manobras deles lá e passa como que o dinheiro foi emprestado e aí direciona isso a 1-2 que vai ......e acaba que visando o interesse do próprio banqueiro então né, é parente dele né? então quer dizer.... o governo vai achar que realmente passou pra 10-12 [produtores], ce vai lá assina uma proposta, ele engaveta sua proposta, como se você já pegou o dinheiro e passa pra outros e enfim....infelizmente o Brasil é isso, essa corrupção que voce ta vendo, a gente vê, no Mato Grosso as lavouras dão certo por causa disso, lá ele planta 1000 hectares de roça, ele financia tudo, pega um mooooonte de dinheiro né?, agora vai financiar aqui 2-3 alqueires........, num consegue nem pagar....é soja ,é milho, é trigo pra exportação..... agora o problema ta no pequeno, o pequeno ta lascado pra sobreviver, tem que fazer isso que eu to te falando, por si mesmo, num tem financiamento, num tem incentivo, num tem nada, essa coisas que vem muito burocrático né?, a pessoa normalmente já é desinformada, chega lá é aquela burocracia, o cara num consegue atingir......tinha que ser mais fácil né?, tinha que ter mais facilidade ao acesso né? ele chega lá já financia, o cara vem aqui pega duas ou três 
testemunhas, -quanto tempo o cara reside aqui?- ah... o cara mora aqui há 30 anos né?, um vizinho que atesta isso né?, que dizer se o cara mora aqui há 30 anos, porque que do dia pra noite ele vai embora, daí você pega..... eu num tenho nada contra os semterra,.... mas você pega o sem-terra...ele dá a terra pro cara, o cara vem num sei da onde, num tem nada no nome dele, ele vai e financia e dá $50 \%$ de desconto pro cara, juro de $6 \%$, ele fais tudo pro sem-terra né?, agora pro pequeno ele num fais, agora o cara que ta lá com a família, ta plantando 5 alqueires de terra ele num financia o cara, num tem como, num tem jeito de você trabalha né?,... [ e o Pronaf? Você conhece?] Já fui também ver, mais .....é isso que eu falei pra você, é aquela burocracia...já começa aquela burocracia danada, aquela coisa, é muito pouco dinheiro né?, solta 5000 reais, o que ce vai fazer com 5000 reais? Num consegue fazer nada, né?, se pega num tem como pagar, é o que eu te falei, então melhor num pegar, né? agora esses cara que planta bastante, eles vão pra todo lado, se eu acertar... beleza, se eu quebrar também, num vou pagar também, mas o cara pegou um monte de dinheiro, ele investe em outra coisa né? , é o que a gente vê, o banqueiro quebra, mas quebra o banco, o cara ta com dinheiro dele investido em outra atividade lá e acabo, num tem essa.

10. A gente pega a mão de obra, no caso o bóia-fria né?, era tudo muito simples até pouco tempo atrás, a gente até...na época do meu pai, a gente tinha, dentro da propriedade, 12 famílias que morava, trabalhava... quando precisava trabalhava na roça do meu pai né?, e tinha o salário dele e junto tinha um pedacinho de terra pra ele mora, cria um porco, uma galinha aí veio o sindicato, veio o sindicato e começou a dar poderes a esse povo, aí o que aconteceu, o cara começou a toma né, o cara morava na casa e ia saí e já tomava a casa do patrão, por que ele tinha direito, ele tava ali dentro né? então, já acabou isso aí, mas agora o governo também agora, já com essa lei nova da previdência também que deu.....equiparou a cidade com o campo né?, o cara tem os mesmos direitos, você coloca uma pessoa pra trabalha hoje, é uma molecada, que não tem consideração nenhuma né?, num respeita nem os pais, vai respeitar um estranho né?, então quer dizer, ele trabalha 1-2 meses, aí quando ele sai, ele vai atrás de direito, você começa a fazer acerto pra um, acerto pra outro, eu tive um caso de uma pessoa que trabalhou pra mim 1 ano, ele foi lá na justiça do trabalho, e falou que trabalhava há 3 anos , arrumou 2-3 caras aí, pagou uma pinga pra eles ir lá e realmente fala que trabalho pra mim há 3 anos e eu num consegui prova o contrário, vou ter que paga 2 anos pro cara, pra ele né?, ele trabalhava pra mim 2-3 dias por semana, passava...., num dia igual hoje, eu num to trabalhando, ninguém ta trabalhando....porque tá chovendo, amanhã ninguém vai ta trabalhando porque tem sol né? você tem as épocas certas pra trabalha né?, o cara foi lá e o juiz deu como ele trabalhava todo dia, o ano inteiro, sábado, domingo, deu descanso semanal remunerado pra ele, sendo que ele trabalhava 2-3 dias pra mim né? ele trabalhava 2 dias por semana, ele deu o sábado e domingo de descanso semanal remunerado, mas isso foi um absurdo, agora como que você vai conseguir trabalha com gente né?, sendo que é um bico, esse serviço eu encaro ele como um bico né?, ele trabalha o dia que ele que, se ele quiser num vir amanhã, ele nem me comunica, ce vai lá chamar ele, ele fala assim, a mulher sai lá fora na rua e fala assim: ah... ele num vai não, ele perdeu a hora, num vai, quer dizer...eu acho o seguinte que a previdência devia fazer o seguinte, fazer o cara pagar como diarista ou bóia-fria, ele ser autônomo, ele recolher a previdência dele, ou o patrão recolher os dias que ele trabalha, o cara tem uma carteirinha, ele vem trabalhar pra você, ele trabalhou 2-3 dias, você anota e no final do mês você vai lá e recolhe do fulano, cicrano e 
beltrano, mas não você.....como você vai registrar uma pessoa dessa, e a justiça num quer saber, a justiça que é falta né?,então foi lá arrumou 2-3 testemunhas, pago lá, falo vai lá, se eu ganhar te dou 50 conto pro ce, e o cara vai lá e fala mesmo: ele trabalho mesmo, vou ter que pagar..... deu 18.000 na conta do advogado dele, porque o advogado dele falou que ele trabalhava... das 6 horas da manhã até 8 horas da noite né?, então já deu um monte de hora extra, que trabalhava todo dia, ele foi inventando né?, ganhava 15 reais por dia.

11. A minha esposa ajuda uns $20 \%$, o resto $80 \%$ é [proveniente]da agricultura mesmo, no caso hoje eu to trabalhando com batata doce, o pequeno tem que sair procurando alternativas, já passou o algodão, passou o milho, o amendoim, foi acabando e o pessoal agora partiu pra batata doce....., aí veio a mandioca como sendo a salvadora da pátria, no final num tá tendo nem preço, ce viu o pessoal, coitado, que plantaram mandioca aí perderam, num vai nem colher, porque num compensa, tem que pagar pra colher, um colega meu colheu um caminhão de mandioca...acho que sobrou... 50 reais, ainda atraso porque...acho que como a mandioca ela vai pra industria aí tem que recolhe ICMS, ele demoro um pouco, acho que para paga o ICMS, num tinha conhecimento disso né?, quando ele foi pagar, tava atrasado, acho que tinha uma multa, num sei o que que é lá, acho que deu 45,00 reais de 50 que sobrou, só sobrou 5 reais... então quer dizer, abandonou, ninguém vai colher..., vai colher como? Então na hora de planta incentiva, faz contato..., aí por dentro do contrato, bem escondidinho, o cara coloca uma cláusula lá né?, ou beneficiando ele em algum sentido né?, porque o cara contrato a 60, mas o pessoal fala, mas a minha era 60, mas na hora que foi colhe o cara fala não era 60 mas ela tem que dar $22 \%$ de renda, e a sua num ta dando, a sua é só 20 ou 30 né, então infelizmente é isso né?, num tem como....

12. Meu pai e eu, meus irmãos já tão fora, porque a propriedade do meu pai é pequena, num tem como trabalha em cima dela, dependendo da atividade que vai desenvolver até funciona (morar mais gente na propriedade) né?, agora, no caso, a gente planta a batata e a batata precisa de bastante terra, porque não é tão rentável, então você tem que ter em quantidade, tem que plantar bastante para ter um volume de produção e daí ter lucro,e... sem contar que não pode fazer no máximo, também 2 planta na terra que tem que já trocar de cultura, plantar um capim pra descansar...e então acaba que tem que tá sempre mudando, então também a propriedade pequena pra esse tipo de lavoura num funciona, a gente tem que ta sempre mudando........

13. Eu acho que em algumas regiões funciona, o pessoal tem uma mentalidade que ... que já convive entre si então acaba que dando certo, mas na nossa região num funciona, já tão tentando fazer e colocara cooperativa, mas eu acho que não funciona não, porque o pessoal já acostumou a tomar cabeçada e faz essas coisas aí e vem com promessa né, na hora que troca o prefeito aí já muda tudo de novo então é cada um pra si mesmo e cada um vai atrás de buscar alternativas e acha o que é melhor, então a experiência......eu nunca fiz parte. Eu vejo na televisão, as vezes passa no "Globo Rural”, a gente.... passa até tudo muito bonito mas eu acho também que só passa uma parte boa, eles catam uma parte boa lá e mostra então até que fica uma coisa bonita mas eu acho que até chegar a isso eu acho que tem muita dificuldade, então sei lá eu acho que acaba num compensando.

14. Eu acho o seguinte, eu penso assim, a gente vive de esperança, né? no caso, na agricultura, agente vive de esperança achando que no outro ano vai ser melhor e que você vai plantar e vai colher mais né? então você vive de ilusão mais..., agora o que 
dificulta e que você num tem preço, as vezes você planta no escuro, é um tiro no escuro, você num sabe se vai produzir, se vai chover na época certa, se...., as vezes até aquela coisa a gente fala que "desgraça de um é alegria do outro" as gente as vezes fica até torcendo pra que um contratempo lá do sul vai vim beneficiar a gente aqui, mais aí se gear lá aí a gente vai vender o nosso aqui , porque infelizmente é assim, tem que.... a produção é muito grande, acaba que num consegue vender tudo né? a questão do preço, o incentivo prá vender, prá industrializar, a gente vê lá no nordeste o pessoal passando fome, aqui num tem quem compra as vezes até joga fora né?, no caso da batata mesmo a gente tira só a parte boa dela, no caso o meio dela que não é a grande nem a pequena né?, o restante poderia ser aproveitado né?, eu acho que o governo deveria aproveitar isso né? vir nessas regiões pegar essa mercadoria leva lá, vende lá, pega baratinho, vende lá né?, acabava que ajudando também, porque você colhe lá $1000 \mathrm{~kg}$, e você só, aproveita só $600 \mathrm{~kg}$, aqueles 400 mesmo que for barato acaba que ajudando pra você paga a mão de obra e vai joga o lucro em cima dos 600, então eu acho que o que falta é interesse, o governo vê que o Brasil é um país agrícola, que tem um potencial, que tem terra, tem que ser da agricultura mesmo, não adianta querer ficar inventando coisa, igual eles(o governo) pensam em fazer, investir muito em tecnologia e ela não ser voltada para a agricultura, eu acho que o Brasil é um país agrícola, tem terra , tem condições de produzir.... agora o que aconteceu, a pecuária, o cara vai investir na pecuária, ele foi cada vez mais... teve que ir avançando (a fronteira), ele não investiu né?, agora que o pessoal começou investir em melhoramento, quer dizer então....demorou, o cara para ele tirar um boi gordo ele demorava 4 anos, então pra isso ele precisava de terra né?, agora ele ta tendo que diminuir porque é inviável, agora o boi chega no ponto de abaste com 2 anos né? então quer dizer, já não precisa de um monte de terra

15. A gente... trabalhar por conta própria é difícil, porque você vive na corda bamba, você não tem ninguém que olha por você, mas você vê tanta corrupção, outro dia tava passando um ministro ganha 8 mil como ele consegue ter uma fortuna de milhões, então você fica desanimado porque você trabalha..... , você produz, você planta, você não tem horizonte, na hora que vai se aposentar dá a maior briga pra se aposentar, aí se aposenta pra ganhar 180 reais, então quer dizer a gente fica desanimado né?, agora o cara que tem um emprego bom né? então ele tem um horizonte, uma perspectiva né? ele sabe que se chover ou fazer sol ele vai ter o salário dele no final do mês e no final do ano ele tem o $13^{\circ}$, então a gente é assim, eu sempre falo, a gente na roça é igual a abelha, ele vai sempre fazendo, fazendo, por que ele não tem uma estrutura, porque o cara que tem um emprego ele tem certeza que no final do mês ele vai receber o salário dele né?, agora o cara que trabalha por conta muitas vezes ele tem um ano bom, ele produz bastante, só que ele tem que guardar porque ele não sabe se no outro ano ele vai ter de novo, então a gente que trabalha por conta é difícil por causa disso, a gente vive sempre inseguro, agora que você começa a comer aquilo que você guardou você já fica desesperado, você num sabe se daqui a pouco você vai ter que comer tudo que você fez, é tudo muito rápido, você demorou muito tempo para construir e para desfazer é muito rápido, então a gente fica...., nunca ninguém na roça está animado né?, porque a gente sabe que na roça é igual a um jogo, você ganha e você perde, então você fica sempre naquela, você num vê um cara que entrou na roça e agora está rico, a num ser estes vereadores (?) que não pagam financiamento então aí na hora que ele se vê rico também aí ele já sai fora da agricultura, aí ele vai investir em pecuária, em fruta 
menos na agricultura porque a agricultura é isso, igual a um jogo, você joga...acerta ganhou e sai fora porque se continuar jogando você fatalmente vai perder. Por enquanto vou continuar (com a batata doce), quer dizer num tem alternativa né?, a gente fica buscando alternativa e você vai ver que todo mundo tá do mesmo jeito, porque a agricultura é sempre isso né? tem a região que produz a batata, tem a que produz a cenoura então não adianta você querer trazer a cenoura e colocar aqui que você vai concorrer com o cara lá que já tem tecnologia, ele já conseguiu e... já aprendeu a trabalhar com aquilo né? que acaba ficando fácil pra ele produzir, então cada macaco no seu galho, só que eu acho que você tem que fazer aquilo que você sabe fazer, que ta mais fácil, que ta perto, é a gente vive de esperança.... achando que o ano que vem vai ser melhor que voce vai produzir mais.... vai ter preço... fica sempre esperando, contando com a desgraça do outro, agora ta esperando prá exportar pra Argentina, pra exportar pra Argentina precisa de frio, lá né?, tem que torcer pra fazer frio, e agora a Argentina ta quebrada......, o que eu acho ruim na agricultura , principalmente na agricultura pequena, assim que você já ta muito perto do seu limite é você num ter segurança, porque se você tem segurança você fala assim oh eu vou plantar essa batata, mas se ela não der você tem uma renda, pra você conseguir comer, beber né?, nosso país num tem subsídio porque robam tudo, ce vê manda dinheiro pra comprar cestas básica o pessoal roba.

16. Aqui no nosso caso depende de tudo (da cidade de Presidente Prudente), banco lá, oficina, pra comprar o adubo, o veneno, é tudo lá né?, depende tudo de lá, pra casa também compra tudo lá, porque se for comprar aqui é tudo mais caro né? você já aproveita. (vocês produzem alguma coisa pra consumo?) Antigamente você ia na propriedade e o cara tinha um frango, um porco, plantava feijão, hoje não, compra tudo, eu lembro quando eu era moleque se viesse um caminhão vender leite aqui ia voltar com o leite tudo pra trás, hoje vem vender leite aqui...., aí o cara tem a propriedade e prefere... acha mais fácil né?, e vai lá e compra o leite de caixinha/ saquinho, aí vai comprar o frango né?, num cria mais....... 
No.4 - Município Presidente Prudente- distrito de Montalvão- 27/7/ 2001- - Me receberam no escritório do barracão onde recebem, lavam e separam em caixas a batata. Planta batata doce.

1. Desde que nasci, desde pequenininho né?, 30 anos mais ou menos.

2. A que nóis reside, a que nóis mora é nossa mesmo né?, e nóis somos vizinhos do meu pai né? que era do meu pai, faz uns 5 anos que eu comprei, antes eu morava com ele aqui na mesma área, aí ele cedeu pra nós essa parte que a gente mora, nós somos em 7 irmãos, mas que trabalha junto, somos em dois, e um dos meus irmãos trabalha de empregado pra nóis, mas sócio meu é eu e meu irmão, Nelson.

3. A área que nóis produze é uma média de 30 alqueires, essa área é arrendada, nossa mesmo é só aqui, é 1 há, a produção nossa é sobre terra arrendada. Hoje ta muito difícil (arrendar terra) porque quem arrenda quer receber á vista né?, recebe em antes de você mexer na terra, e a renda hoje ta muuuito cara, é 500 reais o alqueires, ( por quanto tempo?) você arrenda á combinar né? você combina com o dono da terra, o proprietário, e se você der pra fazer 2 planta, sorte, mas nunca dá pra fazer 2 planta, por ano, o tempo é á combinar, porque á partir do dia que você pega, você tem o prazo de 1 ano, depois tem que entregar. (Essa terra é dada de renda pra ser reformada) aí a gente pega a terra né?, quando chega no final do ano que você combino, passado o contrato tudo, daí você entrega a terra gradeada pra ele, ele joga a semente, os 500 é pelo período todo, você paga quando entra na terra, você faz um contrato porque voce precisa dele, vamo supor, pra levantar um dinheiro no banco, então faz um contrato(formal) né?.

4. Agricultura. Só mexo com a batata, estou na batata faz uns 15 anos, comprando e plantando também.

5. Hoje, nóis mexe com curva de nível, que toda vida teve né?, curva de nível é essencial, porque até o dono da terra exige, e o adubamento, hoje nóis tá trabalhando com o esterco de granja né?, nóis aduba com esterco de granja, joga aí 4 - 5 mil quilo por alqueire, busca em Bastos, paga ele, hoje ele ta 60 real a tonelada , o cara põe aqui pra nóis, a gente espalha ele na terra, gradia a terra de novo, faz as leras e planta, neste esterco, ele já vem o orinho(?), ele já vem o calcário tudo ali, por causa da ração que é dado pra galinha, então já vem tudo que precisa a terra, agora é sempre bom fazer uma análise da terra né? porque aí voce paga o que (essa terra) precisa mais, essa análise faz na Casa da Agricultura, (de graça), quando a gente leva na UNOESTE cobra né?, mais é barato, é importante ( saber das necessidades da terra), sempre é muito importante, saber quanto você vai precisar, porque as vezes você põe uma imensidade de adubo, as vezes nem vale nada...num resolve porque ce não pois o adubo certo né?, (quem te orienta?) a gente orienta na prática, trabalhando, uns falando, outros, tem sempre uns que sabe mais que a gente, tem mais prática, e a gente trabalhando... na terra você vê né?, o que a gente faz, ou não fez naquela área, fez com outra coisa, então ce vai encaixando o tipo da terra, se é uma terra arenosa, se é uma terra massapé né?, então tudo dá diferença e você vai aprendendo na prática.

6. (Ele falou sobre uma agrônoma que eles conhecem) Isso aí é uma Associação que ta tendo aí, começou há uns 2 meses, mais ou menos, então ela ( a agrônoma) ta aí engajada com a gente e ela ta aí pra fazer esse tipo de serviço (dar assistência técnica), é assim né?, ela é formada né?, parece ser boa pessoa e entende, antes disso num tinha, nunca fomo atrás, quando a gente precisava ia na Casa da Agricultura ou no Sakita (loja que comercializa produtos agropecuários), as vezes tinha algum 
problema que a gente num sabia o quê que era, pedia pra outra pessoa, pedia pra um agrônomo da Casa da Agricultura, ou ia no Sakita, ou você leva o problema até lá né?, aí ele orienta a gente como fazer, mais a batata nunca deu esse tipo de poblema né?, é que agora nós entremo com essa outro variedade de batata aí, então ela é... boa, carrega bem, só que o clima daqui é outro né?, então ela numa terra arenosa, agora mesmo eu acabei de crer, que ela não funciona aqui, coisa que a outra vai bem, e ela ta num período de adaptação, (ela é melhor, produz mais, mas precisa de terra melhor), não que a outra também.... ela é até boa, mais por ela já ter muito plantada ela já refinou demais. (Pergunto se ele tem informação sobre pesquisa com a ramas da batata na EMBRAPA, por exemplo, ou ESALQ.) eles mesmo num fala porque eles são novo no ramo né?, eles também tão começando, mas já tem, já ouvi falar que já tem pesquisa ali em Campinas (IAC ?) né?, mas nós nunca entremo em contato, mais aí apareceu essa outra variedade aí, achemo que seria uma boa né?, que já tinha feito também canteiro dela, plantemo também a muda e deu bom resultado, então nóis temo só dela, mais eu tenho visto, pelo tanto que nóis planto, que planto em várias áreas né?, só que a gente tem (plantado) 30 alqueires mas não é num quadro só, é um pedaço aqui, um pedaço ali, então as terras não são iguais, mas por aí a gente vê qual lugar que ela vai adaptando melhor.

7. Vendo, compro e exporto, é a gente compra de fora né?, porque com o que a gente planta num mantém os comprador que a gente tem, então mais é compra, ( nesse 15 anos foi conhecendo os compradores), foi aparecendo eles né?, informação boas e também a gente tem que trabalhar numa boa mercadoria né?, sempre fazendo ela ficar boa, mesmo que seja uma mercadoria ruim, mais uma boa classificação. ( Com relação a exportação), fora daqui é o Uruguai, Argentina, Paraguai, três lugar que nóis exporta mais pra fora né?, e França (foi pouca mais é um bom lugar também), eu tenho vontade de voltar( a vender pra França), os caras sempre procuram a gente mas por causa da qualidade..., como foi muito plantada ela foi tendo uma qualidade muito ruim, na verdade eles acaba pegando a nossa batata mesmo, eles pega em São Paulo mas a batata é nossa daqui (com intermediário), não temos box em São Paulo, vendemos pro pessoal que distribui no CEASA do Rio, em São Paulo é pouco. (pergunto sobre os sub produtos da batata) Nós acha que a que sai daqui é para consumo, frita, assada, no Rio eles faz farinha, faz coxinha, nhoque, doce....Rio e São Paulo tem muito nortista, então é a batata. A batata de mercado (o transporte) é caminhão nosso, do Rio e São Paulo, agora prá fora é carreto.

8. Pra nóis trabalha aqui na batata no barracão, aqui nóis tem a máquina que lava, tem a correia que classifica e carregadeira pra levar até o caminhão, e na lavoura nóis tem os 2 trator, compramos...., novo nóis nunca compramo, porque é muito caro e no dia de amanhã voce vai vender e num tem valor nenhum, então a gente compra um velho e vai se virando com ele né?, essas máquinas nóis temo faz 7 anos, a lavagem era na mão antes, buscava a batata de trator, num tinha caminhão...era uma loucura..... hoje nóis temo condição de soltar até duas carga no dia, naquele tempo nóis tinha condição de soltar, no máximo, duas carga por semana, as máquinas são brasileiras, temos assistência, essa máquina já é a terceira porque gasta muito, usa demais, é sempre, quando num tem batata, usamos pra abóbora, tomate, pimentão, que seje, nóis num plantamos, compramos de outros.

9. Pra roça não, mais é os recursos nossos mesmo e vai se virando né?, a muda é.... você num precisa comprar, o vizinho tem depois passa de um pro outro, foi assim, 
por isso foi aniquilando a muda, com as duas qualidades acabou misturando, nóis comecemo assim.....essa batata...que nem num era essa que tem hoje no mercado, era uma batata de 6 meses, ela demorava seis meses pra dar, aí surgiu... essa eles falam 3-4 meses, essa de exportação, já melhorou, mais antes logo que nóis começou existia só de 6 meses, era uma batata diferente, aí surgiu a de 3 meses, a que tem hoje que já num é de 3 meses, ela já embolou, era coisa da gente ter segurado aquela rama né?, e num ter deixado embolar tanto assim, mais ela foi, foi que acabo, nunca precisou fazer financiamento, usamo o dinheiro nosso mesmo e aí foi aumentando.... ( e o PRONAF?) não..., nunca, (e se você precisar?) Seria bom se houvesse....essas coisas aí é muito difícil, exige muita coisa, hoje eles fala, precisa da pessoa pra avalizar, ou você vai na pessoa pra avalizar, e o problema de avalizar pra certas pessoas é que ele vem e avaliza pra você, no dia de amanhã ele chega pra você, [você pediu pra ele avalizar, por exemplo, 5 mil real], e manda você avalizar 100 mil real, você é obrigado a avalizar pra ele porque ele já avalizou pra você, então é uma coisa que se torna muito difícil né? então é melhor, é mais fácil , se for pra você tocar uma lavoura, vamo supor, uma lavoura com 30-40 alqueires no Banco, você toca uma com 10, e com seu recurso mesmo, se vira e hoje entrar no Banco principalmente pra financiamento é muuito difícil, ich... é difícil demais.

10. Agora nóis na roça nóis ta trabalhando diferente, nóis ta assim, eu preparo a terra né?, deixo a terra na lera, no caso, a gente mesmo faz e com o empregado que tem, é empregado já nosso daqui, da barraca mesmo, que já é pessoal registrado também né?, o que ta aqui ele trabalha todo dia então ele já é registrado também, nóis ta com 6 registrado, e aí, que que eu faço na roça, na roça a gente prepara a terra, entrega enlerado e dá pras pessoas planta de ameia, na produção a gente já fixa a mercadoria também, porque fica a parte da gente e da parte do outro que a gente também compra....., eles acabam vendendo pra gente mesmo né?, porque essas pessoas já são fregueses da gente mesmo, são tudo daqui da região, vizinho, do Montalvão, 18, Timburi, na verdade acaba sendo associação geral, já tivemo pobrema com empregado, mas daqui da barraca mesmo, mais isso daí é coisa que tem...., aí num volta... por isso até que a gente num toca roça sem o sócio, no caso os meeiros né ?, que acaba sendo melhor por que num precisa bóia fria, nóis acha que desse jeito pra nós sai melhor né? porque nóis vai ter a mercadoria..., a pessoa vai ter outro interesse, e eu na hora que chove, eu num vou precisa ir lá na casa do fulano, bater em porta saber se ele vem ou não trabalhar, chamar ele, pagar o dia pra ele, ele vai se virar, ele vai pegar e... correr atrás do serviço, vai tirar rama, vai plantar, e aí se eu tenho 20-30 alqueires, no caso assim, e 2 de a meia quando chove, aquele um vai plantar o cantinho dele, outro vai plantar, outro vai plantar, quando pensar que não já tou com a terra tudo plantada, é a família (do meeiro) já unida (que trabalha) também que vai né?, e ali se eles qué por alguém é por conta deles, eles põe, já pega (a terra) da gente porque já não consegue toca ali sozinho, o ruim da roça é investir no arrendo, porque você tem que ter o dinheiro pro arrendo logo no começo e você num tem nenhuma colheita.... então se torna difícil pra eles também, né?, assim fica fácil pra gente e pra eles, por que a gente entra com a metade do custo e eles entra com a outra metade agora os que pegam a leira pronta pra planta, ele num tem trator, mas ele consegue planta, carpi, colhê, né?.

11. Trabalha tudo em cima da agricultura ( a renda vem toda da agriculturas),a nossa compra, a nossa roça,...tudo vem da batata. 
12. Aqui no que nóis mora, é eu e o meu irmão, o meu pai é vizinho meus irmão mora tudo fora, só a gente mesmo que mora aqui.

13. Essa associação surgiu aí agora, mais num é..., é uma associação pra te um trator na roça trabalhando, já tem o trator né?, mas é pra ajudar também outras pessoas, tem as reuniões pra saber como ta indo a coisa, cada determinado tempo eles marca as reunião pra... falar, discutir os problemas né?, mas é...eles tão muito empenhado, disse que vai trazer agrônomo, que vai trazer, assim, facilidade pra compra um adubo, comprar um veneno.... 30 reais semestral (a contribuição) eu acho que tem uns 50(membros), as vezes faz aqui em casa (as reuniões) ou faz ali em Montalvão, já tem um (presidente) um rapaz, ele e a esposa dele, ele que se encarrega, o Nelson é o secretário, tem conselheiro...tem tudo isso aí. Seria uma boa (o fato de ter se formado essa associação) mas tem que ter união né? primeiramente união, o pessoal anda muito desunido, um puxa prum lado, outro puxa pro outro, a gente ainda ta trabalhando em cima disso pra vê se tem a união, é.. porque num vale nada um só falar vamo faze se os outro num ajudá, não tem nem como aparecer uma verba de fora uma coisa assim né?, porque se não fazer aquele mutirão de ser unido num tem como aparecer né?. A iniciativa da associação foi da Casa da Agricultura.

14. Aqui ajuda, o nosso clima é bom pra batata doce, vichê num precisa melhor, mas o que é ruim aqiu pra nóis é a manutenção, os empregado, os bóia fria judia demais, trabalha aí 10-12 dias aí pra você e se acha no direito de reinvidicar aí alguma coisa, e ganha, mesmo que num ganha você fica ali enrolado um moonte de tempo né? acaba te dando pobrema e são pessoas má , são pessoas que num consideram ninguém, pessoas que se for preciso te dar um tiro ela dá, então a dificuldade é aí. O preço é o alto e baixo né?, O preço hoje é uma coisa, amanhã é outra, as vezes na época que você ta plantando tá uma beleza de repente...., mais isso aí é uma coisa que num é nosso né?, vai faze o que, é ruim, bom se tivesse o preço estipulado né?...mais num é assim, mais eu acho que ela tem que produzi, o $\mathrm{X}$ da estória é faze ela produzi., porque ela tendo uma boa produção o preço sempre dá. O preço num dá pra você fala: eu vou planta batata pra vender a 10 real caixa já foi vendido, nóis já compremo, mais é aquela coisa passageira né?, hoje ta 3 reais, já foi a menos de 1 real a caixa, porque a menos num dá pra você manda, o preço da embalagem custa 1,5, aí você num manda, aí perde... e aí você vai ver o problema que voce tem, dá fim naquilo, você num pode largar aquilo lá, porque e aí o arrendatário vai querer a terra ou mesmo que ele num for arrendatário, for o dono da terra ele tem que dar fim naquilo. (Você tem vontade de comprar terra?) A gente pensa sim, tem vontade mais é muuito difícil nóis também num queria sair daqui né?, pra mexer no ramo que nóis mexe, porque pra sair daqui tem que trocar de ramo né?, e o que nóis sabe faze é só isso mesmo...

15. A é ficar por aqui tudo que é outra coisa se muito difícil, porque a batata vai produzir o ano inteiro e já outras coisas tem a época do ano e... nóis nunca se empenhamo com outras coisa né? pra mexe e o nosso lugar aqui produz bem batata, então eu acho que num tem necessidade de ir atrás de outras coisas. A gente é o $1^{\circ}$ comprador da região, então a gente fica na batata mesmo. Meu menino gosta de fica na roça com a gente em volta de mim.

16. Prudente é tudo né? Prudente tem tudo que a gente precisa , banco, médico, supermercado... 
No.5 - Município Presidente Bernardes-

Fui recebida na casa deles. -Planta batata doce.

1. Eu nasci na atividade, meu pai era empregado... eu, desde pequeno, estou há 18 anos por conta própria..., estou com 41 anos.

2. ....e foi aonde que eu comprei aqui, ele(o pai) trabalhava na agricultura, naquela época ele plantava amendoim, aí depois eu casei né?e aí eu comecei a plantar batata, aqui eu

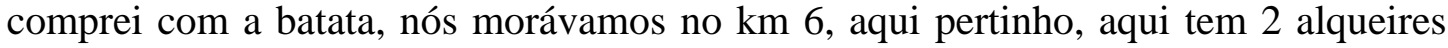
né?.

3. Não planto nada aqui. Eu arrendo terra por fora, nestes 18 anos sempre arrendei, está muito difícil (arrendar)....é muito difícil, o preço e muito alto e também falta terra disponível pra gente podê planta, voce bate em 10 dono de terra pra conseguir arranjar, as vezes a gente passa um contrato por causa do talão do produtor, um contratinho..., o preço tem de duas formas que eu conheço, ou voce paga á vista ou você planta o capim... por ano ou até por planta. Aqui tem gente pagando 500 até 700 reais por planta, você só planta uma vez essa batata e depois você vai embora, você pega ela no gramão, aí você prepara ela e planta a batata, dentro de uns 6-7 meses,... colhe e larga a terra sem capim, agora quando você pega a troco do capim aí é diferente, por que você não paga nada e planta o capim depois.

4. [ É arrendatário] na agricultura

5. é muito pouca, eu procuro assim escolhe uma terra de gramão, uma terra mista, só de olha, mais a gente tenta adivinha, a semana passada, em Piquerobi o cara me ofereceu 20 alqueires, uma terra muuito bonita assim de longe , eu fui lá vê só que não dava a terra... vermelha né?, aí você nem adianta faze análise, talvez é uma terra muito boa né?, mas pra outra coisa não pra batata. A batata eu aprendi (a plantar/ o cultivo) trocando idéia né?, eu, no meu caso gosto muito de conversar, as vezes é uma pessoa que é um bóia fria que te dá uma idéia excelente, igual eu gosto muito de experimentar... adubos novos que sai, eu me informo né?, pra batata o adubo tem que ser bom pra raiz, o nome (científico do componente) eu não sei

mais...eu sei o que precisa.....

6. Num tem, eu procuro entre a gente né?, as vezes você procura um agrônomo as vezes pra sabe alguma coisa e pela resposta dele você vê que num tem nada a vê com aquilo que você quer saber, mas ele também num fala que não sabe, um exemplo, teve um agrônomo aqui, ele apareceu há uns 8 anos vendendo adubo, próprio pra batata, ele vendeu pra todo mundo, só que foi só conversa..., não tenho assistência técnica. Quando eu fiz financiamento pelo Banco do Brasil, fais uns 6 anos atrás, tem um agrônomo, ele ganha até 200 reais pra faze, eu falei: você não vai lá ver a lavoura?, ele falou: não! eu não, eu entendo de tomate...você entende mais do que eu..., falou bem claro.

7. Vendo no atacado, pro intermediário sempre, a gente fala por telefone, sempre com pessoas conhecidas, foi conhecendo né?, [e o preço], varia muito né?, eles é quem manda, ce nunca manda no preço da sua mercadoria, é péssimo né?, porque se eu tiver pouco eu mando, se tiver muito ele manda, [ o que faz o preço estar melhor ou pior], falta de mercadoria, [e a qualidade faz diferença?], não, é só a falta, influencia pouco [a qualidade] muuito pouco, quando a batata ta em falta você manda qualquer biroquinha que você vende, agora quando tem muita..., [eles vem buscar?], não,eu mando pra eles, pro Rio, São Paulo, tudo CEASA, [qual é a quantidade?], depende... 
depende da época, se voce pega frete, você manda um caminhão por semana, se você tiver menos você manda menos, num tem um limite, por exemplo, um contrato com eles, antes de mandar eu ligo...

8. O trator eu comprei em 90, e o caminhão também, tudo com a batata, comprei a vista, era usado...

9. Não, não faço sempre não, só um pra plantar batata, custeio né?,[no que usou o dinheiro?], pra pagar a renda, comprei adubo, comprei calcário, [em conjunto com outros proprietários ?] comprei sozinho, geralmente [o prazo] é 30 dias, eles tem um plano safra aí, mais é de 3 mês, prá batata num vale nada..., um juro violento, ah! pra batata tem que ser de 6 mês, pra da tempo de colher, por que pra arrancar daqui 4-5 mês, depois você vai mais 1 mês pra pode recebe, então o de 3 meses num vale nada. [e o PRONAF, já ouviu falar?], já ouvi falar sim mais eu não fiz, esse um que eu fiz com recursos meus, ele se afina com o PRONAF, inclusive eu fui providenciar pra mim fazer o PRONAF, que eu queria...12.000, o que eu fiz, esse é uma linha difícil [Banco do Brasil] 8,5 \% [de juro a.a ], eu só consegui com conhecimento [avalista], o PRONAF é 5\%, esse ano eu fui fazer o PRONAF, ver se eu conseguia, por que é mais fácil é menos burocracia,, aí a moça [do Banco] falou: você não se encaixa mais no PRONAF, por que você já fez noutra linha, mais eu num queria tirar $12.000 . .$. , então eu num consegui tirar, eu queria 5000 e o juro era mais barato 5\%, o outro de 12.000 é $8,5 \%$.

10. Eu tenho 2 né? que trabalha sempre pra mim, num são registrados, tenho muito medo, eles eram registrado, mais eu pagava 60 reais cada um por mês, é... pro estado ficar roubando da gente, então eu procurei pegar 2 pessoas que toda vida trabalho pra mim, pessoas que eu considero muito, eu acho que num vão me dar pobrema né?, agora...é arriscado, o resto é bóia fria né? esses num tem como..., quando você vai plantar...você só usa (bóia fria) quando você vai plantar ou arrancar, quando você vai plantar, você vai lá cedo e pega, a tarde você larga, paro a chuva... só planta quando tem chuva, 10 reais (a diária), 8 horas por dia de serviço, para na hora do almoço..., pago no final de semana. Hoje eu to gastando 25 dias pra plantar 1 alqueire, mas já gastei $45 . .$. , pra você ter uma idéia, porque as vezes você pega uma terra difícil pra planta, entendeu, ela tá com muito buxa (?), rama muito difícil pra tirar... porque esses 25 dias tá incluído entre plantar e tirar rama (tirar as pontas dos brotos da batata), as vezes tá muito difícil pra tirar a muda, que é tirado de outra rama e leva pra outra roça, então uma média entre tirar e plantar, é 25 (dias) por alqueire, até hoje, plantei no máximo 20 alqueires e o mínimo 10 alqueires, agora eu to com um sócio e quero plantar mais, 50 alqueires. Então pra plantar eu emprego mais ou menos 45 pessoas.

11. A renda vem só da agricultura, só da batata, já plantei outras coisas, as vezes você pega a terra um ano, a batata até você colher, 10 alqueires, ela demora 7 meses então sobra 3 meses aí eu planto abóbora assim , uma coisa mais rápida pra num dar pobrema com o fazendeiro num fica parada a terra se eu planta batata vou demorar 15-16 meses pra tirar, aí fica ruim né? Vendo sempre pra São Paulo, Rio...tem consumo né?

12. Duas famílias, nós e meu pai (viúvo).

13. Faço parte lá do Sindicato Rural, agora da cooperativa tá formando ainda...a associação, ouvi falar que ta formando, eu acredito que se for uma coisa séria...eu acredito porque... aqui é muito difícil, os outros falou pra você também, um tenta comer o outro você entendeu?, se eu entrego no lugar que você entrega, eu sempre 
ponho 10 centavos mais barato, pra mim poder entrar, depois que eu entrei daí é diferente né?, então se você entrega num lugar eu num consigo entregar, nós não somos unidos, mas se funcionar direito (a associação) vai ajudar, [o que precisa para funcionar direito?] eu acho que menos pessoas , que tenha mais responsabilidade, eu acho que se fossem umas pessoas de fora da batata, estou com vontade de participar....

14. Eu acho que a maior dificuldade aqui pra nós é a terra, pra você achar terra é muito difícil..., é muito difícil..., eu acho que eu não ter a terra é a maior dificuldade, e eu acredito que pra todos daqui é,...eu tinha vontade de ter terra (ser proprietário)...a gente planta bastante né?, mas também num precisava ser minha a terra entendeu, ter com fartura terra pra gente arrendar, daqui uns dois anos você num acha nenhum palmo de terra, já ta tudo plantada, tudo terra veia, lá a usina (Alto Alegre) pegou tudo né?, aqui num acha...cada dia que passa fica mais difícil. [Você já ouviu falar do Banco da Terra? ] já ouvi, mas eu acho que pra mim num serve pelo que eu ouvi falar, num conheço né? eu ouvi fala que eles vai dar 5 alqueires, parece que vai fazer uma colônia de 10-20 produtor e dar 5 alqueires pra cada um...,eu nem quero..., pra mim não funciona eu toco 30-40 aqui, e ter que morar em cima vai passa fome em cima dos 5, a num ser que..., se você botar um japonês lá numa quarta que você der pra ele, ele toca, ele pega melhor que a gente né?...

15. Não tenho vontade de deixar (a agricultura) não, nem de mudar, só se for obrigado mesmo né? os planos são de aumentar ainda mais, só que é difícil né? mais meu plano é aumentar, [e sua filha?] minha filha não tem vontade nem um pouco, nem eu queria também né?, ainda mais pra mulher, esse trabalho pra mulher é complicado....

16. Banco né?que a gente usa mais, oficina, supermercado, roupa também mais o que eu uso mais é oficina.... 
No.6 - Produtor 8/2001- Dona Maria(I) e esposo

Pecuária de leite e fruticultura

1. Estou há 20 anos aqui no sítio, é bastante tempo né?. Eu estava na cidade e deu vontade de vim pro sítio né? e eu enraizei e fiquei 20 anos né?, eu tinha comércio de roupas mais ou menos 10 anos com conserto, com costura, depois mudou pra comércio de roupas prontas, e depois mudei pra cá...

2. A área é de 17 (alqueires) mais quando eu comprei era de um inventário de uma senhora, tudo abandonado aqui, era um pasto... num tinha nada, aí eu pedi pra uma senhora: olha, eu to tão esgotada na cidade, eu quero ir pra sítio, me arruma um. Aí ela me arrumou esses 3,5 alqueires. Começou com 3,5 alqueires, eles (os antigos proprietários) eram de Prudente, depois o (meu) filho....como tinha vizinho também, um senhor de idade, aí foi deixando...qué ir prá cidade e falô que queria vende, aí o filho que compro...então agora são 17 alqueires do filho que está em São Paulo. Era tudo pasto...uma casinha velha lá ...reformamo...uns 2 anos nós viajando... vinha fim da semana...os parentes com tudo aí...depois aí vendeu a loja, aí começou a construir essa casa aqui.

3. Agora...aqui era manga, mas no fim o comércio ficou muito ruim, no começo até que não foi ruim, a plantação no começo a manga era mais bonita, dava mais produção...agora com o tempo, a manga também...quando ficou velho, o pé cresceu, a gente num tem jeito de jogar veneno então ficou meio abandonado, aí depois o comércio ficou ruim porque o preço já num dava, se por veneno...já era mais gasto e num dava retorno né?, então cortamo a manga ...já tem pouco, pra vende num serve mais. Temos também um pouco de ponkã, também foi a mesma coisa, no começo dava mais, depois os pé foram ficando velho e cansado, que nem nós, e pra cuidar nós num damo conta e os veneno...se a gente quiser tratar é muito caro, muito caro, diz que é multinacional (o produto) num sei o que...mas assim mesmo nós tamo cuidando né, porque já ta no sítio sem fruta sem nada é duro né?, mas assim mesmo a gente ta cuidando pra manter. $\mathrm{O}$ restante é pasto, tem Tanzânia, brachiaria, né?, a gente pergunta pra um e pra outro e a gente foi melhorando né?. Lá em baixão tem um pedaço que é um rio, quando vem chuva pesada vem a erosão, leva cerca tem que fazer de novo, perde arame, ta bem afastado agora, assim mesmo tem um pedaço que num dá pra usar.

4. As mudas comprou aqui em Prudente. Vendia mais aonde eu entrego leite, pra consumidor né?, e um pouco no Pastorinho (supermercado em Prudente) mais foi comércio com o Pastorinho, eles quebra galho pra gente, então agente vendemo pra eles né?, Tenho aqui pecuária de leite e fruticultura.

5. Não, num fizemo nada, foi deixando assim natural(as mangueiras) num fizemo nada de mais, nunca fomo atrás de nenhum agrônomo, nem a ponkã, chamava de vez em quando, mais não vale tanto a pena porque se fizer do jeito que eles querem num há dinheiro que chegue, então a gente vai só por cima né?, num tem jeito. O leite eu tinha (assistência técnica), eu entregava no laticínio Santa Clara né?, mas o preço mal e mal só pra paga a despesa do empregado porque era muuuito barato, muuuito barato, no começo foi muito...poucas vacas 5-6 só pra consumo nosso mesmo, daí foi aumentando... no começo entregava mais pra família, aí o leite aumentou e abriu... né? acho que uns 12 anos vendeu pro Laticínio Santa Clara, o preço agora no ano passado o mais que chegou foi 38 [centavos], agora ta no 35 (Agosto/01), no tempo de ter muito(leite) é até 28 [centavos]. 
6. Eles falava que tinha (assistência técnica) mas nunca tinha certo, sempre chamava mas num adiantava, aí eu tinha que chama particular mesmo, eu sempre chamei particular, de Regente [Feijó] (cidade sede do município) eu nem conhecia então mais fácil chamar pessoa que já ta acostumado, que sempre vem aqui, no fim a gente mesmo se virava porque sai caro né?, deixava remédio comprado e a gente vai levando.

7. Nunca vendi na feira, nem pro CEASA, vendia pra intermediário, levava direto pra supermercado, só supermercado, é porque aqui é muito pouco num tem jeito de esparramar né?, se começa a entregar numa coisa tem que ter responsabilidade né? tem que levar sempre aquele dia aquele horário, mais aqui é muito pouco, a área é pouca, as fruta é pouco e só nós dois num tem como né?, eu estou com 71 anos e ele 82.

8. Tem um trator que compramo bem usado né? acho que tem uns 10 anos, tem todo implemento mas tudo usado, num dava pra compra novo né? então sempre foi comprando os velho.

9. Não nunca, sempre foi com dinheirinho nosso mesmo a gente vai tocando, ele num gosta...(o marido), é em Prudente (o banco que eles trabalham), [e o PRONAF?] nunca ouvi fala.

10. Tem um que é fixo, assalariado ele é retireiro né?, porque como tem o leite ele tira o leite e cuida do pasto, roçar o que tem..., carpir o pomar, as vezes põe algum assim quando vê que ele num vence põe algum por dia, diarista né?.

11. O que ajuda mais (na renda) é a aposentadoria do meu marido porque o meu é um salário só, tinha casa também de aluguel (2), tinha telefone em 6 anos foi tudo aí... (na propriedade), renda daqui é muito pouco, nós ficamo aqui até agora porque tem aposentadoria e tem essa casa aqui, mas agora nós vendemo a casa também e tamo aplicando aí agora. (Eles estão de mudança, arrendaram o sítio para ser usado como área de lazer e vão residir na cidade de Prudente, os filhos estão preocupados com os pais devido a idade deles)

12. Só nóis dois, o empregado, que é o casal, e duas filhas.

13. Só sindicato de onde eu faço o pagamento cooperativa rural né?, que eu faço a folha de pagamento do empregado e compro os remédios, na Cooperativa Mista em Prudente. Não, nunca participamos de nenhuma reunião, sempre vem convite mas nós nunca fomos. Eu num entendo nada porque eu num vou porque eu num resolvo nada, então num participa, eu acho que num resolve nada, mais se a gente falasse alguma coisa resolvesse era bom né?, mais acho que fica sempre naquela lenga-lenga fica sempre na mesma né? Que nem calcário, eu pedi pus aí mais você tem que buscar em Marília, como que vai fazer?... então a gente punha esterco, calcário comprado tudo, eu falei uma vez com o presidente do sindicato rural de Prudente(Ishi) e eles nem ligam...

14. Nós num fomo atrás nada porque a gente num entende nada e a gente vai mais num resolve nada, então vem tocando... o bom é a saúde (da vida no campo), muito ar bom, água bom né?, e tranqüilidade então isso foi bom, aí ficamo 20 anos sem perceber, hoje mesmo eu falei será que nóis ficamo 20 ano mesmo !?. Satisfeito com o preço nunca fomo, que nem agora planto feijão um pouquinho o empregado né?, o que que dá?... a gente já num tem irrigação, o tempo já num ajuda (pouca chuva) aí dá feijão tão feio né?, e num tem jeito de fazer comércio, então eu acho que esse sítio é muito difícil, num tem.... 
15. Nós tamo mudando porque com a idade que nóis tamo, tamo meio cansado e os filho está preocupado e nóis vamo muda pra cidade né?, agora vamo ter lugar pra salão de festa... tamo começando, o plano é ter uma área de lazer pra (alugar) fim de semana. Os filhos moram todos em São Paulo, estudaram lá e começaram a trabalhar e num volto mais pra cá. Não, não pensam (em vir) porque o serviço deles é lá mesmo aqui num tem futuro pra eles né?, eu acho que eles num pensam em morar aqui não.

16. De Regente a gente usa muito pouco, mais é vacinação de gado que pertence lá né?, a gente leva na casa da lavoura... mais acho que é só, Prudente é tudo, banco, supermercado, roupa, médico todo em Prudente, oficina.... 
No.7 - Produtor - 8/2001

1. Uns 20 anos, eu tenho 30 anos.

2. Isso aqui meu pai que compro há mais ou menos 25 anos, que ele compro essa propriedade, a gente morava no Paraná, plantamo café lá e foi aonde que a gente conseguiu dinheiro e compramo aqui, ele já tinha morado antes na região aqui (de Presidente Prudente), nasceu aqui foi pro Paraná e depois voltou. Na década de 70, era café e pasto.

3. Aqui são 14 hectares, metade ( 7 ha) é pasto e metade ( 7 ha ) é plantação. A gente uma veis planta num lugar outra veis no outro, sempre...

4. Tem hortaliças e agropecuária, de leite, como a área é pequena num dá pra engordar. Sempre foi assim, uma parte é leite e outra parte é agricultura. Quando a gente começou a plantar... era café, mas já plantou de tudo...algodão, feijão, milho, arroz e depois começou a plantar com mais freqüência hortaliça...legume: berinjela, jiló, vagem, quiabo, abobrinha, pepino. A gente decide mais ou menos na hora hein, de repente vê assim o que está melhor, o que está girando melhor, pelo preço, quando o preço vê que ta melhorando, coisa e tal...que eu conheço mais de plantar é berinjela... milho (pro gado e verde).

5. Agente aduba, tem curva de nível, análise do solo nunca fiz não, [alguém te orientou ?] não, a gente aprendeu e pergunta pros outros, aqui perto só tem uma fazenda grande o resto é tudo menor, o pessoal mexe mais com leite.

6. Não recebo assistência técnica de ninguém, nem agrônomo nem veterinário, eu precisei [de agrônomo] pra laranja, aí eu paguei, de Prudente. [ Onde você compra as sementes e mudas que você usa?] Compro em Prudente, no Sakita e em casas que vendem, o preço é bem puxado hein..., tem nacional e importada é o bolso que vai decidir, a importada é melhor na qualidade, vamos supor: o pimentão- a semente- 10 g, custa 70 reais, eu acho um absurdo isso, num tem como[ser mais barato] porque todo lugar é o mesmo preço, a berinjela já é barata, mesmo a importada. O pimentão eu planto pouco porque é muito caro então se eu investir muito eu posso perder né?.....a berinjela eu planto, se perder o preço é mais barato. O leite hoje, a gente ta tirando uns 30 litros, as vacas são cruzadas, temos um touro que nóis compramo. [E o leite vendem pra quem?] Entrega prô cara e ele revende lá em Regente, colocamos lá a 0,35 centavos, ele vende a 0,70 centavos, de ameia. Já vendemos pra laticínio- Lecohá mais ou menos 10 anos.

7. A gente vende para o supermercado Estrela (em Regente Feijó), as vezes eu entrego pra feirante de Prudente, agora pra intermediário é difícil a num ser quando eu planto mais, aí o que sobra...berinjela, jiló, quiabo, essas coisas [e o preço pago pelo supermercado?] o preço ta bom e dependendo da época eu tenho sempre produção (de hortaliças), pros feirantes eu levo...sempre eu tenho uma coisa plantada colhendo e uma plantação a caminho pra num falta, [exporta?] pra exporta num dá porque a produção é pouca, [comercializa frutas?] assim quando é época de laranja (tem pêra rio, baiana e ponkã), já tive problema de cancro (cítrico) mais dái eu consegui controlar com defensivos agrícolas, o agrônomo veio aí e ta resolvendo.

8. A gente tem um trator e o equipamento dele: grade, tombador, carreta, roçadeira, a gente compro há um 4 anos atrás [novo?] não, usado, num tem condição só se vende o sítio, vai quebrando e a gente vai arrumando. 
9. Não eu nunca fiz[financiamento], o meu pai já fez só uma vez quando ele plantou algodão, pagou direitinho só que nunca mais quis fazer porque era a mesma coisa que num tivesse feito porque num virou nada. [e o PRONAF?] já ouvi fala mais...

10. Temo uma empregada que ajuda minha mãe, mensalista, agora os outros quando assim a gente planta bastante coisa daí a gente pega por dia, pegamo em Regente mesmo, ou as vezes pega no sítio, algum conhecido né?, a gente vai atrás porque é pertinho e tal, a gente vai atrás da pessoa eu a gente conhece e chama , pagamo o que corre na região, 10 reais o dia, assim a gente pega mais o pessoal na época de planta e talvez algum dia pra colhe, eu também trabalho, o que mais trabalha sou eu. O que eu pude economizar eu economizo (porque faz o trabalho de muitos). [ Qual é o ciclo da berinjela?] Bom, desde a semeadura até a produção é 90 dias,[e o jiló] é a mesma coisa, a época dela é o ano inteiro, só tem que ter água [você tem irrigação?]Tem, comprei com próprio dinheiro da hortaliça. Contrato no máximo de 1 a 2 empregados, as vezes dependendo da coisa que for plantar daí usa mais, nunca tive problema[trabalhista].

11. Não, a renda vem toda da propriedade, só minha mãe é aposentada.

12. Olha, agora é uma só porque já teve mais né?, mais casou...só ta os solteiros com a mãe. Os casados moram em São Paulo e Campinas, e tem uma irmã que mora aqui no [bairro] Sete Copas.

13. A gente faz parte do sindicato de Regente, pelo menos ali...a gente é bem atendido, agora a pouco tempo a gente compramo adubo né?, pelo sindicato, eles... a gente se reuniu e comprou em grande quantidade pra sair mais barato, o pessoal que faz parte do sindicato todos eles entraram....[e associação de produtores?] Eles tão comentando em fazer aqui no bairro uma associação, mais por enquanto ainda não, mais tão tentando fazer sim...eu acho que funciona sim, pela associação um vai ajudar o outro... o custo é menor...

14. Se eu tivesse mais terra..., porque a quantidade de terra que a gente tem é pouco, então dá só pra fazer o que a gente faz, planta horta que usa pouca terra, mais se eu tivesse condição de ter mais terra eu ia mexer só com gado, com gado de engorda ou pra ir criando, se eu tivesse condições..., bom aqui é bom porque a gente o que faz aqui... porque ninguém manda na gente, a gente mesmo vamo supor, que é o patrão eu que decido o que fazer e num tem que ficar mandando na gente....

15. Por enquanto eu vou continuar [na mesma atividade], vou arrendar uma pequena área, é uns 2 hectares próximo daqui onde que tem água mais né?...a vontade, então eu to pretendendo plantar mais... de tudo: pimentão, berinjela, vagem, jiló, abobrinha...legume e futuramente a gente vê se tá compensando... [você já pensou em ir embora daqui?] Não, não pretendo sair daqui não.

16. Em Regente eu uso oficina, remédio, defensivos, a não ser que não tenha, na falta compramo em Prudente, médico em Regente, sementes geralmente em Prudente. Pra melhorar só a chuva vindo agora né?, e ver se o dólar para de subir pra as coisas da gente num ficar tão abaixo do que já ta né?[Depois da entrevista fomos ver as frutíferas, a horta e o gado de leite] 
No.8- Produtor hortifrutigrangeiro é arrendatário.

1. Nesta atividade eu já estou praticamente há 1 ano e 4 meses, eu estou hoje aqui por vários fatores que aconteceu na minha vida né?, e um dos maiores fatores é que eu gosto de plantar horta, então sempre morei no sítio e como a vida inteira eu andava nas horta e admirava...meu maior sonho era um dia plantar horta,[ seu pai trabalhava na mesma atividade?] o meu pai plantou legumes, era berinjela, jiló, pimentão, pepino e numa propriedade que por sinal... praticamente vizinha dessa propriedade que eu estou trabalhando hoje. Meu pai era proprietário do sítio, ele não tinha condição de comprar uma irrigação, não tinha condição de comprar um trator, era cultivado com animal [tração animal] e a gente foi desanimando porque as chuvas foram ficando escassas entendeu? De maneira que a gente chegava no CEASA com o nosso produto e a gente perdia o cliente pela qualidade, porque você chegava com a berinjela ela era menor, mais murcha, num tinha brilho, o tomate era mais miúdo, o pepino era menor ele num tinha a cor verde escura que o do vizinho, do japonês o outro vizinho, tinha produzido com irrigação, então a gente perdia na qualidade.[em que ano isto ocorreu?] 1986, mais ou menos, na década de 80 praticamente foi que a gente plantava legumes, antes disso, plantávamos amendoim e algodão, antes da década de 80 , a propriedade era no município de Santo Anastácio (SP), era um sítio aí vendeu lá pra vir pra cá, porque as terras aqui eram melhor e o preço que a gente pegou lá deu pra comprar um sítio maior aqui, a gente vendeu lá 3 alqueires e comprou um de 5,5 aqui.

2. Agora aqui eu pago renda, eu arrendo hoje três quartas de terra, fiz um contrato anual, vence daqui a 6 meses, o contrato ele está especificado nos seguintes termos: eu arrendo três quartas de terra no valor de 100 reais por mês, entendeu ? e que nesses 100 reais tá incluído: um micro trator Tobata, que tem em torno de 28 anos de uso mais ou menos, tá incluído uma irrigação completa com motor elétrico, o tanque, os canos, os aspersores; salvo esse ramal que eu montei lá que eu te mostrei agora pouco, deve ter mais ou menos uns 250 metros de irrigaçäo mais ou menos no total de cano, e nesse contrato tem um item que especifica que eu devo...é... dar a manutenção em todo esse equipamentos, inclusive eu tive uma infelicidade muito grande que no segundo mês... já ter que reformar o trator, mais isso ai eu estava ciente e eu sabia que essa dificuldade no começo eu ia ter né? a bomba eu tive que dar uma reforminha, o trator...... e tá sujeito daqui uns dias a bomba do poço eu ter que mexer, o poço artesiano.... bomba fica praticamente funcionando de 8 a 10 horas por dia, e eu tenho que dar manutenção que especifica no contrato e nesses 100 reais eu tenho que pagar a energia que é gasta na casa que é propriedade da dona Maria, que é a proprietária do sítio, então a energia ela não paga...

3. A área aqui deve ter mais ou menos 4 alqueires, eu não sei..., é só três quartas, quer dizer um pouco mais que $1 / 2$ alqueire é o que eu cultivo, o restante é pastagem, ta alugada pra pasto, prá outra pessoa...é leite que eles tiram...é um pessoal de Regente Feijó que vem aí tirar o leite.

4. Eu sou horticultor, a única fruta que a gente planta e que eu tenho planos de aumentar a produção é o moranguinho, a única fruta que eu planto.

5. A técnica e a tecnologia que eu uso aqui é uma técnica que eu adquiri a experiência com o Dr. Pedro da Faculdade [de Agronomia], lá do Agripino [da UNOESTE], que a gente procura seguir a risca não usando o agrotóxico que não é permitido pra horticultura, se a gente ainda não produz uma agricultura orgânica estamos bem 
próximos usando o esterco de galinha, a casca do amendoim pra fertilizar a terra e usando adubo foliar né? pra melhorar a qualidade da folha e a gente segue a risca desde a produção de mudas, a produção de mudas a gente faz aqui no local mesmo. A gente planta alface, almeirão, couve, rúcula, chicória, cebolinha, salsinha...tudo isso aí em bandeja de isopor, mudinha por mudinha pra depois você levar para os canteiros. A gente faz análise da terra, pelo menos uma vez por ano pra ver o que que falta na terra, se ta faltando calcário, se ta faltando adubo orgânico, se alguma composição da terra ta falha, como os nutrientes que precisa pra produzir as hortaliças, isso é feito lá na Faculdade mesmo, aí eles dão a receita né?...você tem que aplicar mais calcário, mais adubo orgânico ou algum componente. Faço as curvas de nível, curvas de contenção, porque neste período no mês de agosto, que a gente está né?, é uma época do ano que praticamente não chove...agora quando pende pro final do ano, aí são chuva 4-5 dias toda semana, aí tem que ter as curvas de nível pra conte a água porque a terra é muito úmida, de repente arrebenta tudo e você perde tudo com a chuva, então tem que ser muito bem preparada senão...

6. Eu não tenho recebido assim... visita periódica de algum agrônomo, mais eu procuro na casa da Agricultura de Regente Feijó quando eu tenho alguma dificuldade, por exemplo, esta semana mesmo eu estava com dificuldade em produzir o rabanete, eu tava tirando o rabanete muito bonito, muito viçoso, só que todo ruidinho, com as cascas furadas, aí eu catei um feixinho e levei lá para um agrônomo olhar e ele me orientou, ele não vem aqui, eu que procuro lá, mais ele me deixou a disposição o telefone que se eu precisar, que se não conseguisse resolver podia ligar pra ele...

7. A minha produção é praticamente $80 \%$ pra consumidor, uns $20 \%$ eu entrego pra uma quitanda (intermediário) que vende para oconsumidor.

8. A única máquina que eu tenho aqui é um micro trator, Tobata, muito antigo por sinal, ele já tem 28 anos de uso e é o que eu uso aqui pra fazer os canteiros, ele é bem obsoleto, é bem antigo mais é a minha ferramenta principal, eu não posso ficar sem. Tenho também irrigação, que funciona a energia elétrica, que não é a óleo diesel que eu usava na outra horta quando eu estava de sócio com meu irmão.

9. Nunca fiz financiamento, neste período de 1 ano e 4 meses que eu estou nesta área de horticultura, nunca fiz e nem pretendo. Pelas experiências que a gente tem nestes anos todos, que meu pai fez, inclusive quando ele vendeu o sítio...ele desanimou porque ele fez um financiamento pra plantar abobrinha e teve que praticamente vender boa parte dos bens que ele tinha para pagar esse financiamento. Então a gente já tem uma certa experiência, que os juros são altos, os encargos são muito altos e a gente num tem coragem de chegar no banco e pedir financiamento, é claro que faz falta né? Eu pra começar aqui neste arrendamento, eu saí de uma sociedade, que era com o meu irmão, a gente era entre família, sócios, eu deixei ele lá com a horta andando, quer dizer produzindo...e saí com a cara e a coragem, eu peguei com um amigo 400 reais pra comprar o $1^{\circ}$ adubo, a $1^{\circ}$ semente, a $1^{\mathrm{a}}$ remessa de bandejas pra plantar, a $1^{\mathrm{a}}$ tonelada de esterco de galinha e assim por diante, 400 reais foi o meu início pra começar a atividade, e pago o juro até hoje e não consegui pagar...depois de 4 meses. [Conhece o PRONAF ?] Não conhece, vejo falar no rádio mais não tenho assim por detalhes, pormenores né? como funciona e que finalidade tem não sei...

10. Contrato diaristas, eu tenho aqui 2 ou 3 diaristas constantemente, não é fixo, é pra serviços gerais: plantar mudas no canteiro, colher, fazer manutenção nos encanamentos, irrigar a horta, enfim serviços gerais....Problemas com empregados 
ainda não tive, mais corro o risco, a gente corre o risco porque vários amigos nossos enfrentaram o problemas, inclusive a $\mathrm{D}^{\mathrm{a}}$ Maria aqui (proprietária do sítio), ela teve um problema muito sério com um funcionário. (Eu conheço a $\mathrm{D}^{\mathrm{a}}$ Maria há muitos anos, praticamente quando ela chegou no sítio, porque em 1974 a gente chegou aqui no sítio vizinho e ela chegou aqui...acho que no mesmo ano, ela morava aqui no trevo próximo a Prudente e quando eles vieram pra cá a gente via eles construindo a casa, aplainando aqui o lugar que ia ser a horta, e a gente ficava de lá admirando... óia pai lá tem irrigação...mais o pai não quis...achava que era muito caro.

11. A participação praticamente é toda... tudo que a gente compra aqui é.. a gente consegue aqui [com a renda] na horta, por exemplo: material pras crianças, a despesa com a perua [Kombi, usada para transportar a produção], gasolina, empregados, energia elétrica, adubo, semente...tudo a gente consegue através da venda que a gente faz das verduras aqui da horta, não tenho outra atividade, nem outra renda.

12. Aqui residem uma família só, que é a $\mathrm{D}^{\mathrm{a}}$ Maria e seu esposo seu Júlio. Eu moro em uma chácara vizinha, que por sinal foi uma sorte muito grande, eu ter conseguido esta chácara aqui do lado, de um amigo meu...é esse amigo nosso foi pro Japão ficou 2 anos lá e voltou e negociou com o vizinho aqui do lado, a chácara, e ele vai voltar, já está com a passagem comprada, ele chegou né mim e falou olha: você ta com dificuldade, viajando todo dia pra Regente Feijó, você num quer pegar a chácara aí pra tomar conta, aí eu disse pra ele: eu to com um problema muito sério, já pago aqui a renda que é 100 reais, que parece pouco pra quem ta de fora, mais pra quem ta trabalhando é muito, e eu num posso assim assumir um compromisso de pagar um aluguel pra você, aí ele falou assim: Não..., você me mantém a propriedade limpa, o pomar cuidado, é... me mantém a energia, você paga aí a energia, mantém ligadinho, tudo certo e você num precisa me pagar nada de aluguel. Foi aonde eu resolvi mudar pra cá, foi uma troca... e aí tem só fruta, não está produzindo nada pra comercializar, o único acordo que a fez com ele é que na época da laranja e da ponkã, o que produzir o pomar será dividido em 2, a metade pra mim e a metade eu entrego aqui pros filhos dele que ficaram, que não foram pro Japão.

13. Eu não faço parte de nenhuma cooperativa, mais eu tenho um sonho muito grande, que o município de Regente Feijó ou mesmo de Presidente Prudente, deveria ter um incentivo dos prefeitos daqui da região, pra que se formasse uma cooperativa dos pequenos agricultores ou pequenos horticultores, né?, como queiram, que eu acho que essa cooperativa deveria ser dividida em vários grupos. O maior sonho que a gente tem é que tenha uma cooperativa que funcione, porque já foi montada uma aqui no município, só que era uma cooperativa dos agricultores que produziam cana no municípios, aí a usina foi a falência e não pagava ninguém, enfim faliu essa cooperativa, mais uma cooperativa dos pequenos horticultores que realmente funcione. O que que é funcionar: seria o prefeito destina um barracão, destinar umas 3 a 4 pessoas pra administrar, um pra sair colhendo assinaturas dos pequenos horticultores, olha você quer entrar? Você quer participar?..., mesmo que fosse cobrado uma taxa de manutenção, olha nós vamos ter lá 3 funcionários, esses funcionários vão ser sustentados através de vocês, vai ser $\mathrm{X}$ pra cada um por mês, seria vantagem pra gente pagar, porque eu acho que seria justo cobrar, mais que teria uma pessoa ali ao dispor da gente o dia todo, pra andar na cidadezinha no supermercado: olha eu tenho esse produtor que produz rúcula, tenho esse produtor que produz moranguinho, esse outro produtor que produz alface americana, outro produz alface crespa e a gente consegue 
manter aqui tantos maços de alface todo mês e aí fazer o negócio funcionar, seria esse o meu sonho, agora a gente só vender em feira fica limitado, porque você não consegue expandir a sua produção, você fica limitado naquela produção, produz aí $\mathrm{X}$ maços por semana e não tem condição de aumentar porque não tem pra quem vender. Eu sou uma pessoa muito curiosa nesta área de cooperativas, eu acho que realmente funciona porque no Distrito Federal, eu tava lendo uma reportagem no globo rural, tem uma cooperativa que progrediu muito, inclusive hoje eles tem uma frota de carretas, muito bem montadas com baú refrigerado e o produto que eles produzem lá está sendo mandado pra Manaus: pimentão e vários tipos de legumes, e poxa vida! daqui em Brasília quantos quilômetros são? Porque não mandar produtos nossos pra lá, porque não mandar pra Cuiabá, não se produz folhas lá, eles tem uma dificuldade enorme de produzir hortaliças lá, pra Ponta Porá, onde não se produz hortaliça nenhuma...então seria através dessas cooperativas é que nós ia ter um intercâmbio pra fornecer para um local distante. num adianta eu produzir aqui 10 mil pés de alface por mês se eu num tenho balcão frigorífico, se eu num tenho caminhão refrigerado pra mandar pra uma cidade que está daqui a 500 km, eu num tenho condição. (Eu estudei até a $4^{\mathrm{a}}$ série do primário, a gente morava aqui no sítio vizinho, eu terminei aqui numa escolinha de sítio que é até só a $4^{\text {a }}$ série do primário, aí na época a foi na cidade e comprou o uniforme, comprou o material e cruzemo os braços e ficamos esperando o ônibus que o prefeito prometeu que ia mandar...e ficamos esperando um bom tempo e nunca veio, o meu pai num tinha condição de levar todo dia, a gente num tinha meios, somos em 6. [Nesta parte ele falou dos irmãos]

14. O que facilita, o que é bom hoje você trabalhar na horta é que você num tem tantos encargos fiscais, eu loto essa perua de alface e vou numa feira e vendo e não pago imposto, este seria um lado bom, mais é um e nove contra porque eu tenho o tempo [clima] eu tenho a chuva que é demais, eu tenho a doença que é demais, muita bactéria, muito vírus, tem uma infinidade [de dificuldades]..., o custo...de insumos, do adubo, do fertilizante, do esterco, do combustível e pra acabar de interar agora o racionamento de energia, que é o meu caso aqui, eu dependo de energia pra puxar água do poço pra irrigar...mais em termos gerais...o horticultor[o proprietário] sofre mais que qualquer empregado, o horticultor a disponibilidade de falar assim: $2^{\text {a }}$ feira é feriado, eu vou parar hoje $6^{\mathrm{a}}$ feira a tarde e fazer uma pescaria, ele não pode, a verdura é um ser vivo que depende do cuidado 12 horas por dia, só não se rega a verdura a noite, essas mudas que você ta vendo aqui eu tenho que estar aqui 12 horas por dia, são 11 horas os empregados vão almoçar e eu venho aqui pra molhar, as vezes vou almoçar 1-2 horas da tarde, eu tenho que me dedicar a isso daqui a semana toda , o mês todo, o ano inteiro.

15. Eu tenho plano de diversificar e ampliar, mais ao mesmo tempo a gente fica preso a dificuldade financeira, se eu tivesse hoje um incentivo do governo, é... o gerente do banco chegasse aqui na porta da propriedade que eu arrendo e falasse: olha aqui tem uma verba que o governo ta destinado aos pequenos produtores, você num vai precisar ir atrás de endossante, porque eu num gosto de pedir favor pra vizinho, porque é um risco muito grande, se eu tivesse condição eu ia aumentar a produção de moranguinhos que tem uma aceitação muito boa no mercado, eu ia plantar legumes que eu tenho prática, eu planto isso aí desde criança, berinjela, abobrinha, xuxu, tomate, vagem, pepino rasteiro e envarado, eu tenho muita prática em legumes, e sonho também em ter minha propriedade, ficar livre do aluguel(da terra), porque você 
pergunta ah mais quanto você paga, ah pago 100 reais, é muito barato, aqui tem uma estrutura que vale muito mais que 5000,00 reais você só paga 100 é barato, eu concordo, só que você já viu quantos pés de alface eu tenho que vender pra pagar 100 reais, são 200 maços, porque cada maço hoje custa 0,49 centavos pra mim, eu não tenho lucro, eu sobrevivo, eu empato, nesta época agora de 0,50 centavos o maço você deixa de pagar um e paga o outro, quando eu arrendei aqui eu consegui vender a 1 real o maço, de 1 real veio pra $0,90,0,80,0,70$, eu até posso vender a 0,70 mais as vezes não consigo vender tudo e volto com 150 maços, e meu vizinho de feira vende mais barato...cativa os clientes e quando tiver mais caro eles não vão comprar de mim, o problema não é bem a seca, a seca ajuda a verdura a produzir, por incrível que pareça, ao contrário do que muita gente imagina, é ao contrário, quando está seco que não chove é que se produz alface, o sol, ele impede pouquinha coisa de se produzir um alface com qualidade, vamos supor que ele dê um prejuízo de 10 a $15 \%$ somente, agora a chuva chega a dar 70 a $80 \%$ de prejuízo, a geada chega a dar um prejuízo muito grande, que num é o caso aqui do local que eu estou...

16. Os serviços que eu uso constantemente da cidade, é o serviço público, eu vou lá no posto de saúde levar minha filha pra consultar, eu vou numa farmácia comprar um remédio, no mercado comprar, praticamente, tudo que a gente se consome aqui, é o arroz, o feijão, é o legume, que eu não planto, tem que comprar na cidade, ir num banco pagar uma conta de luz, conta de telefone. Oficina eu uso de Regente Feijó, em Prudente eu faço a feira, e uso também o banco pra pagar uma conta, semente eu compro em Prudente e compro em Álvares Machado na cooperativa. O preço varia muito, hoje uma latinha de $300 \mathrm{~g}$ de alface crespa tá em torno de 28 a 30 reais, ela é americana, o que eu acho uma pouca vergonha, eu acho que o governo deveria investir mais nesta área por que, veja bem, uma latinha de $300 \mathrm{~g}$ “comum”, que é a semente sem ser peletizada, que é uma semente envolvida com uma matéria prima muito parecida com farinha de trigo, muito parecida com o gesso, que eu num defini o que que seria está matéria prima, mais é um pó, ela é compridinha muito difícil de lidar com ela, a peletizada que é redondinha, dá um pezinho só cada tubinho, ela rende mais, ela conserva mais a qualidade da semente porque ela está envolvida em numa capa, ela num requer um cuidado especial como a semente sem ser peletizada, por que ela não adquire umidade, umidade do tempo, vamos supor choveu, está aquele tempo úmido, você num pode estar manuseando semente comum, porque se você guardar ela, ela mofa tudo na lata, e você perde uma lata de semente, dá um prejuízo muito grande, já aconteceu de perder, já a peletizada não, você pode trabalhar com ela sossegado, ela só vai germinar quando ela entra em contato com o substrato que você rega ela, que molho, e além do mais você tem economia de mão de obra, porque você plantou uma sementinha em cada quadradinho da bandeja...plantou uma, nasce uma, a outra não, você não consegue plantar uma, tem que jogar 2-3, aí quando nasce você tem que pagar ali a diária pro funcionário tirar 2-3, o problema que eu acho hoje é uma grande pouca vergonha de o Brasil ter que importar uma semente, nós temos que pagar aqui um imposto tão caro por uma semente peletizada, nós deveríamos ter essa técnica já aqui há muitos anos, nós deveríamos ter investido em pesquisa, a gente tem tanta faculdade aí, tanto professor competente que poderia desenvolver uma pesquisa e ver como que é peletizada essa semente, que material que se usa, entendeu?, vamos fabricar uma máquina e produzir a nossa semente, pra que isso? Hoje eu não taria pagando 49 reais por $300 \mathrm{~g}$ de semente peletizada, enquanto que uma semente comum, 
na mesma quantidade, custa 14-15 reais, uma diferença enorme de custo, entendeu?, este fato de vir essa semente de lá , passa pelo distribuidor, ele distribui, isso se torna muito caro, por isso que eu falo que uma associação funciona, por que que funciona, se tivesse hoje no município de Regente Feijó uma associação dos pequenos horticultores, eu consumo $300 \mathrm{~g}$ por mês de semente peletizada só da alface americana, só dela, um exemplo, mais o meu amigo consome 5 latas, o outro consome 10, o outro 3... então todos os do município de Regente Feijó daria um montante que poderíamos nós entrar em contato lá nos Estados Unidos, já que nós não temos um produtor aqui no Brasil, e comprar direto, eles fornecem pras cooperativas, sairia um custo mais baixo, nós íamos ter sempre semente nova, entendeu? Sempre que eu quero dizer é sempre com o vencimento mais longo, porque as vezes você compra semente numa loja com o vencimento próximo a vencer, se segurou 4-5 meses perdeu, então cê num pode, tem que comprar uma por uma, por que a semente ficou velha você perde na qualidade, já a muda nasce menorzinha, ela é muito sujeita a virose.[a seguir ele relata alguma coisa sobre seu conhecimento sobre horticultura]Bom eu fiz um cursinho, num pode nem se dizer que é curso, por que curso é quando você freqüenta a sala de aula e você pega a coisa desde o começo e você escreve alguma coisa, você entendeu?, e ali você está com o professor pelo menos uma semana, o curso que eu fiz, ele foi um curso rápido demais, foi praticamente 2 dias, eu fui um dia lá na faculdade do Agripino[UNOESTE] falar com o Dr. Pedro, ele me orientou assim... poucas horas, e ele me levou na horta, me detalhou algumas doenças mais freqüentes, alguns defensivos, que eu poderia usar mais comuns, e depois me convidou pra ir na faculdade que ele dá aula, lá em Paraguaçu Paulista, a gente fez essa pequena viagem até lá e ficou lá praticamente um dia todo lá, aí sim ele levou na horta que ele mesmo da aula lá, se eu não me engano ele é reitor lá, aí ele levou a gente pra horta, explicou com maiores detalhes, levou pra uma sala lá, me deu uma apostila de presente, entendeu?, isso me valeu demais, eu devo muito ao Dr. Pedro, inclusive eu tinha vontade e nunca tive oportunidade de fazer uma homenagem pra ele um dia até no meio de um público, entendeu? numa rádio por exemplo, meu maior sonho é chegar no meio de uma rádio ou televisão e elogiar ele, agradecer ele, ele num cobrou nada, ele perdeu tempo, eu já liguei várias vezes no celular dele...então eu acho um homem... que ajudou sem interesse algum, só por gostar, por ver que a gente tava saindo do zero, e não tinha experiência nenhuma, e olha eu admiro demais o Dr. Pedro por que, pois olha ele é uma pessoa que merece estar onde ele está hoje e a Dona Maria, a proprietária do sítio[que ele arrenda] também, que ela tem uma vida inteira, praticamente nasceu na horta, de criança ele aguou a horta de regador, de noite! Sem enxergar nada, nem querosene pra lamparina num se podia ter na época, entendeu?, ela disse que cansou de levantar as 2 horas da manhã, ela e a irmã dela, isso com 15 anos de idade, e catar 2 regador e ir na mina, correndo o risco de uma cobra picar e tudo, e catar água e sair regando, aqui mesmo onde eu estou arrendando hoje, eles chegaram a regar a horta com regador, num faz muitos anos que eles montaram a irrigação, que fez o poço artesiano, que colocou funciona a energia elétrica, uns 7-8 anos! 


\section{ANEXO 2 - \\ AS 10 PRINCIPAIS CULTURAS / ÁREA POR \\ MUNICÍPIO- DADOS LUPA-1997 \\ REGIONAL AGRÍCOLA DE PRESIDENTE PRUDENTE}


PRINCIPAIS CULTURAS / TOTAL - ÁREA DO EDR - PRESIDENTE PRUDENTE

\begin{tabular}{|l|l|c|}
\hline CULTURAS- GRUPO & CULTURAS- NOME & ÁREA (ha) \\
\hline Pastagem & Braquiária & 621.004 .00 \\
\hline Pastagem & Outros capins *1 & 60.496 .00 \\
\hline Cultura semi-perene & Cana-de-açucar & 34.971 .50 \\
\hline Cultura anual & Milho & 28.353 .20 \\
\hline Cultura anual & Algodão & 16.849 .30 \\
\hline Cultura anual & Feijão & 8.522 .80 \\
\hline Florestal & Eucalipto & 5.557 .60 \\
\hline Cultura anual & Amendoim & 4.093 .20 \\
\hline Cultura anual & Batata-doce & 2.557 .20 \\
\hline Cultura perene & Fruticultura de mesa *2 & 1.796 .10 \\
\hline Cultura perene & Café & 1.181 .20 \\
\hline
\end{tabular}

FONTE: SAA-ESP- PROJETO LUPA/1997

ORGANIZAÇÃO: MEDEIROS- 2002.

* 1-incluem: Capim gordura, Capim Jaraguá.

* 2- incluem: Abacate, Abacaxi, Laranja, Manga, Melancia. 
AS 10 PRINCIPAIS CULTURAS/ÁREA POR MUNICÍPIO- DADOS LUPA-1997

REGIONAL AGRÍCOLA DE PRESIDENTE PRUDENTE

\begin{tabular}{|c|c|c|}
\hline \multicolumn{3}{|c|}{ MUNICÍPIO - ALFREDO MARCONDES } \\
\hline CULTURAS & ÁREA CULTIVADA ( ha ) & PERCENTAGEM \\
\hline TOTAL & $12.098,70$ & $100 \%$ \\
\hline BRAQUIÁRIA & $6.335,00$ & $52,36 \%$ \\
\hline OUTROS CAPINS & $3.534,70$ & $29,22 \%$ \\
\hline MILHO & 569,5 & $4,70 \%$ \\
\hline ALGODÃO & 445,1 & $3,68 \%$ \\
\hline FEIJÃO & 385,3 & $3,18 \%$ \\
\hline BATATA DOCE & 356,0 & $2,95 \%$ \\
\hline AMENDOIM & 183,9 & $1,52 \%$ \\
\hline CANA-DE-AÇÚCAR & 123,4 & $1,02 \%$ \\
\hline EUCALIPTO & 97,4 & $0,80 \%$ \\
\hline CAFÉ & 68,4 & $0,57 \%$ \\
\hline
\end{tabular}

FONTE: SAA-ESP- PROJETO LUPA/1997

ORGANIZAČ̃̃O: MEDEIROS-1999.

\begin{tabular}{|c|c|c|}
\hline \multicolumn{3}{|c|}{ MUNICÍPIO - ÁLVARES MACHADO } \\
\hline CULTURA & ÁREA CULTIVADA (ha) & PERCENTAGEM \\
\hline TOTAL & $30.373,60$ & $100 \%$ \\
\hline BRAQUIÁRIA & $16.401,90$ & $54,00 \%$ \\
\hline OUTROS CAPINS & $10.380,30$ & $34,17 \%$ \\
\hline MILHO & $1.279,20$ & $4,21 \%$ \\
\hline ALGODÃO & 745,0 & $2,45 \%$ \\
\hline AMENDOIM & 359,9 & $1,18 \%$ \\
\hline CANA-DE-AÇÚCAR & 340,5 & $1,12 \%$ \\
\hline FEIJÃO & 294,7 & $1,00 \%$ \\
\hline BATATA DOCE & 214,5 & $0,70 \%$ \\
\hline CAPIM NAPIER & 211,5 & $0,69 \%$ \\
\hline EUCALIPTO & 146,1 & $0,48 \%$ \\
\hline
\end{tabular}

FONTE: SAA-ESP- PROJETO LUPA/1997

ORGANIZAÇÃO: MEDEIROS-1999. 


\begin{tabular}{|c|c|c|}
\hline \multicolumn{3}{|c|}{ MUNICÍPIO - ANHUMAS } \\
\hline CULTURA & ÁREA CULTIVADA (ha) & PERCENTAGEM \\
\hline TOTAL & $29.823,00$ & $100 \%$ \\
\hline BRAQUIÁRIA & $27.467,50$ & $92,10 \%$ \\
\hline MILHO & 747,6 & $2,51 \%$ \\
\hline OUTROS CAPINS & 406,5 & $1,36 \%$ \\
\hline FEIJÃO & 249,0 & $0,84 \%$ \\
\hline MELANCIA & 181,0 & $0,60 \%$ \\
\hline ALGODÃO & 177,9 & $0,59 \%$ \\
\hline EUCALIPTO & 163,9 & $0,56 \%$ \\
\hline CAFÉ & 163,6 & $0,56 \%$ \\
\hline BATATA DOCE & 140,1 & $0,45 \%$ \\
\hline ABACAXI & 125,9 & $0,43 \%$ \\
\hline
\end{tabular}

FONTE: SAA-ESP- PROJETO LUPA/1997

ORGANIZAÇÃO: MEDEIROS-1999

\begin{tabular}{|c|c|c|}
\hline \multicolumn{3}{|l|}{ MUNICÍPIO - CAIABU } \\
\hline CULTURAS & ÁREA CULTIVADA ( ha) & PERCENTAGEM \\
\hline TOTAL & $18.792,70$ & $100 \%$ \\
\hline BRAQUIÁRIA & $14.322,00$ & $76,21 \%$ \\
\hline CANA-DE-AÇÚCAR & $2.058,80$ & $10,95 \%$ \\
\hline MILHO & 896,10 & $4,76 \%$ \\
\hline ALGODÃO & 601,40 & $3,20 \%$ \\
\hline FEIJÃO & 505,40 & $2,68 \%$ \\
\hline EUCALIPTO & 111,10 & $0,60 \%$ \\
\hline AMENDOIM & 90,30 & $0,50 \%$ \\
\hline BATATA-DOCE & 86,80 & $0,47 \%$ \\
\hline CAPIM COLONIÃO & 72,00 & $0,38 \%$ \\
\hline MELANCIA & 48,80 & $0,25 \%$ \\
\hline
\end{tabular}

FONTE: SAA-ESP- PROJETO LUPA/1997

ORGANIZAÇÃO: MEDEIROS-1999 


\begin{tabular}{|c|c|c|}
\hline \multicolumn{3}{|c|}{ MUNICÍPIO - EMILIANÓPOLIS } \\
\hline CULTURA & ÁREA CULTIVADA (ha) & PERCENTAGEM \\
\hline TOTAL & $19.909,10$ & $100 \%$ \\
\hline BRAQUIÁRIA & $18.060,00$ & $90,71 \%$ \\
\hline MILHO & 705,0 & $3,54 \%$ \\
\hline ALGODÃO & 574,7 & $2,88 \%$ \\
\hline FEIJÃO & 201,8 & $1,01 \%$ \\
\hline CANA-DE-AÇÚCAR & 121,1 & $0,60 \%$ \\
\hline AMENDOIM & 62,3 & $0,31 \%$ \\
\hline EUCALIPTO & 60,6 & $0,30 \%$ \\
\hline ABÓBORA & 48,2 & $0,25 \%$ \\
\hline SORGO & 46,7 & $0,24 \%$ \\
\hline CAPIM NAPIER & 28,7 & $0,16 \%$ \\
\hline
\end{tabular}

FONTE: SAA-ESP- PROJETO LUPA/1997

ORGANIZAÇÃO: MEDEIROS-1999.

\begin{tabular}{|c|c|c|}
\hline \multicolumn{3}{|c|}{ MUNICÍPIO - ESTRELA DO NORTE } \\
\hline CULTURA & ÁREA CULTIVADA (ha) & PERCENTAGEM \\
\hline TOTAL & $24.256,70$ & $100 \%$ \\
\hline BRAQUIÁRIA & $22.159,10$ & $91,35 \%$ \\
\hline MILHO & 615,1 & $2,53 \%$ \\
\hline ALGODÃO & 477,3 & $1,96 \%$ \\
\hline EUCALIPTO & 328,9 & $1,36 \%$ \\
\hline BATATA DOCE & 285,2 & $1,18 \%$ \\
\hline AMORA(BICHO-DA-SEDA) & 116,2 & $0,48 \%$ \\
\hline CANA-DE-AÇÚCAR & 89,5 & $0,37 \%$ \\
\hline FEIJÃO & 85,1 & $0,36 \%$ \\
\hline TOMATE & 60,6 & $0,25 \%$ \\
\hline MANDIOCA & 39,7 & $0,16 \%$ \\
\hline
\end{tabular}

FONTE: SAA-ESP- PROJETO LUPA/1997

ORGANIZAÇÃO: MEDEIROS-1999. 


\begin{tabular}{|l|l|l|}
\hline MUNICÍPIO - IEPÊ & ÁREA CULTIVADA (ha) & PERCENTAGEM \\
\hline CULTURAS & $51.275,30$ & $100 \%$ \\
\hline TOTAL & $34.841,60$ & $67,95 \%$ \\
\hline BRAQUIÁRIA & $6.640,30$ & $12,95 \%$ \\
\hline SOJA & $5.703,20$ & $11,12 \%$ \\
\hline CANA-DE-ACÚCAR & $3.519,50$ & $6,86 \%$ \\
\hline MILHO & 133,8 & $0,26 \%$ \\
\hline EUCALIPTO & 124,1 & $0,24 \%$ \\
\hline PINUS & 93,4 & $0,18 \%$ \\
\hline SORGO & 80,4 & $0,16 \%$ \\
\hline CAFÉ & 75,0 & $0,15 \%$ \\
\hline FEIJÃO-FRADINHO & 64,0 & $0,13 \%$ \\
\hline SERINGUEIRA & & \\
\hline
\end{tabular}

FONTE: SAA-ESP- PROJETO LUPA/1997

ORGANIZAÇÃO: MEDEIROS-1999.

\begin{tabular}{|c|c|c|}
\hline \multicolumn{3}{|c|}{ MUNICÍPIO - INDIANA } \\
\hline CULTURA & ÁREA CULTIVADA (ha) & PERCENTAGEM \\
\hline TOTAL & $8.041,40$ & $100 \%$ \\
\hline BRAQUIÁRIA & $6.242,50$ & $77,62 \%$ \\
\hline FEIJÃO & 465,7 & $5,80 \%$ \\
\hline MILHO & 452,6 & $5,62 \%$ \\
\hline ALGODÃO & 239,1 & $3,00 \%$ \\
\hline SERINGUEIRA & 144,0 & $1,79 \%$ \\
\hline MELANCIA & 116,7 & $1,45 \%$ \\
\hline CAFÉ & 113,7 & $1,41 \%$ \\
\hline EUCALIPTO & 96,8 & $1,20 \%$ \\
\hline CANA-DE-ACUUCAR & 88,2 & $1,09 \%$ \\
\hline BATATA DOCE & 82,1 & $1,02 \%$ \\
\hline
\end{tabular}

FONTE: SAA-ESP- PROJETO LUPA/1997

ORGANIZAÇÃO: MEDEIROS-1999. 


\begin{tabular}{|c|c|c|}
\hline \multicolumn{3}{|l|}{ MUNICÍPIO - JOÃO RAMALHO } \\
\hline CULTURA & ÁREA CULTIVADA (ha) & PERCENTAGEM \\
\hline TOTAL & $38.421,60$ & $100 \%$ \\
\hline BRAQUIÁRIA & $30.540,80$ & $79,48 \%$ \\
\hline CANA-DE-AČÚCAR & $4.409,80$ & $11,47 \%$ \\
\hline AMENDOIM & $1.528,50$ & $4,00 \%$ \\
\hline MILHO & 623,1 & $1,62 \%$ \\
\hline CAPIM-NAPIER & 491,6 & $1,27 \%$ \\
\hline EUCALIPTO & 235,2 & $0,61 \%$ \\
\hline MANDIOCA & 190,2 & $0,50 \%$ \\
\hline SOJA & 142,8 & $0,38 \%$ \\
\hline CAFÉ & 138,0 & $0,35 \%$ \\
\hline NABIÇA: híbrido de nabo e mostarda & 121,6 & $0,32 \%$ \\
\hline
\end{tabular}

FONTE: SAA-ESP- PROJETO LUPA/1999

ORGANIZAÇÃO: MEDEIROS-1999.

\begin{tabular}{|c|c|c|}
\hline \multicolumn{3}{|c|}{ MUNICÍPIO - MARTINÓPOLIS } \\
\hline CULTURAS & ÁREA CULTIVADA (ha) & PERCENTAGEM \\
\hline TOTAL & $99.467,40$ & $100 \%$ \\
\hline BRAQUIÁRIA & $80.556,90$ & $81,00 \%$ \\
\hline CANA-DE-ACÚCAR & $4.719,80$ & $4,74 \%$ \\
\hline ALGODÃO & $4.544,80$ & $4,56 \%$ \\
\hline MILHO & $4.471,00$ & $4,50 \%$ \\
\hline FEIJÃO & $2.293,60$ & $2,30 \%$ \\
\hline CAPIM COLONIÃO & $1.484,60$ & $1,50 \%$ \\
\hline FEIJÃO-DE-LIMA & 483,0 & $0,50 \%$ \\
\hline MELANCIA & 427,5 & $0,41 \%$ \\
\hline SORGO & 246,6 & $0,25 \%$ \\
\hline CAFÉ & 239,6 & $0,24 \%$ \\
\hline
\end{tabular}

FONTE: SAA-ESP- PROJETO LUPA/1997

ORGANIZAÇÃO: MEDEIROS-1999. 


\begin{tabular}{|l|l|l|}
\hline \multicolumn{2}{|l|}{ MUNICÍPIO - NANTES* emancipado após o levantamento } \\
\hline CULTURA & ÁREA CULTIVADA (ha) & PERCENTAGEM \\
\hline TOTAL & $20.378,00$ & $100 \%$ \\
\hline BRAQUIÁRIA & $10.878,10$ & $53,38 \%$ \\
\hline CANA-DE-AĆ́́CAR & $3.982,40$ & $19,54 \%$ \\
\hline OUTROS CAPINS & $2.792,60$ & $13,70 \%$ \\
\hline SOJA & $1.493,50$ & $7,33 \%$ \\
\hline MILHO & $1.034,50$ & $5,08 \%$ \\
\hline EUCALIPTO & 74,6 & $0,37 \%$ \\
\hline SERINGUEIRA & 55,0 & $0,26 \%$ \\
\hline MANGA & 26,6 & $0,14 \%$ \\
\hline ABACATE & 26,2 & $0,13 \%$ \\
\hline MELANCIA & 14,5 & $0,07 \%$ \\
\hline
\end{tabular}

FONTE: CATI-REGIONAIS AGRÍCOLAS DE DESENVOLVIMENTO RURAL-1997

ORGANIZAÇÃO: MEDEIROS-1999.

\begin{tabular}{|c|c|c|}
\hline \multicolumn{3}{|l|}{ MUNICÍPIO - NARANDIBA } \\
\hline CULTURA & ÁREA CULTIVADA (ha) & PERCENTAGEM \\
\hline TOTAL & $30.622,20$ & $100 \%$ \\
\hline BRAQUIÁRIA & $27.960,3$ & $91,31 \%$ \\
\hline ALGODÃO & $1.349,9$ & $4,40 \%$ \\
\hline MILHO & 627,3 & $2,05 \%$ \\
\hline SOJA & 193,6 & $0,63 \%$ \\
\hline EUCALIPTO & 173,5 & $0.57 \%$ \\
\hline CANA-DE-AÇÚCAR & 93,4 & $0,30 \%$ \\
\hline TOMATE & 72,5 & $0,24 \%$ \\
\hline SORGO & 68,5 & $0,23 \%$ \\
\hline AMORA(BICHO-DA-SEDA) & 49,2 & $0,16 \%$ \\
\hline ARROZ & 34,0 & $0,11 \%$ \\
\hline
\end{tabular}

FONTE: SAA-ESP- PROJETO LUPA/1997

ORGANIZAÇÃO: MEDEIROS-1999. 


\begin{tabular}{|c|c|c|}
\hline \multicolumn{3}{|c|}{ MUNICÍPIO - PIRAPÓZINHO } \\
\hline CULTURAS & ÁREA CULTIVADA (ha) & PERCENTAGEM \\
\hline TOTAL & $38.717,70$ & $100 \%$ \\
\hline BRAQUIÁRIA & $35.423,20$ & $91,50 \%$ \\
\hline ALGODÃO & $1.313,30$ & $3,40 \%$ \\
\hline MILHO & 588,5 & $1,52 \%$ \\
\hline CANA-DE-AÇÚCAR & 506,0 & $1,30 \%$ \\
\hline BATATA-DOCE & 233,6 & $0,60 \%$ \\
\hline FEIJÃO & 219,6 & $0,57 \%$ \\
\hline EUCALIPTO & 157,2 & $0,40 \%$ \\
\hline CAPIM COLONIÃO & 119,6 & $0,30 \%$ \\
\hline SORGO & 82,6 & $0,21 \%$ \\
\hline CAPIM-NAPIER & 74,1 & $0,20 \%$ \\
\hline
\end{tabular}

FONTE: SAA-ESP- PROJETO LUPA/1997

ORGANIZAÇÃO: MEDEIROS-1999.

\begin{tabular}{|c|c|c|}
\hline \multicolumn{3}{|c|}{ MUNICÍPIO - PRESIDENTE BERNARDES } \\
\hline CULTURA & ÁREA CULTIVADA (ha) & PERCENTAGEM \\
\hline TOTAL & $56.969,50$ & $100 \%$ \\
\hline BRAQUIÁRIA & $49.781,20$ & $87,38 \%$ \\
\hline CANA-DE-ACÚCAR & $2.529,80$ & $4,44 \%$ \\
\hline MILHO & $1.546,40$ & $2,71 \%$ \\
\hline ALGODÃO & $1.449,6$ & $2,54 \%$ \\
\hline FEIJÃO & 699,5 & $1,22 \%$ \\
\hline AMENDOIM & 235,6 & $0,41 \%$ \\
\hline TOMATE & 230,0 & $0,40 \%$ \\
\hline EUCALIPTO & 191,3 & $0,35 \%$ \\
\hline CAPIM NAPIER & 164,1 & $0,30 \%$ \\
\hline АВÓBORA & 142,0 & $0,25 \%$ \\
\hline
\end{tabular}

FONTE: SAA-ESP- PROJETO LUPA/1997

ORGANIZAÇÃO: MEDEIROS-1999. 


\begin{tabular}{|c|c|c|}
\hline \multicolumn{3}{|c|}{ MUNICÍPIO - PRESIDENTE PRUDENTE } \\
\hline CULTURA & ÁREA CULTIVADA (ha) & PERCENTAGEM \\
\hline TOTAL & $36.609,20$ & $100 \%$ \\
\hline BRAQUIÁRIA & $27.822,60$ & $76,00 \%$ \\
\hline CANA-DE-AÇÚCAR & $4.392,70$ & $12,00 \%$ \\
\hline MILHO & $1.522,40$ & $4,14 \%$ \\
\hline BATATA DOCE & $1.096,70$ & $3,00 \%$ \\
\hline FEIJÃO & 445,0 & $1,21 \%$ \\
\hline ALGODÃO & 441,9 & $1,20 \%$ \\
\hline CAPIM-COLONIÀO & 293,4 & $0,81 \%$ \\
\hline EUCALIPTO & 219,5 & $0,60 \%$ \\
\hline MANGA & 191,7 & $0,53 \%$ \\
\hline LARANJA & 183,3 & $0,51 \%$ \\
\hline
\end{tabular}

FONTE: SAA-ESP- PROJETO LUPA/1997

ORGANIZAÇÃO: MEDEIROS-1999.

\begin{tabular}{|l|l|l|}
\hline MUNICÍPIO - RANCHARIA & ÁREA CULTIVADA (ha) & PERCENTAGEM \\
\hline CULTURAS & $132.250,50$ & $100 \%$ \\
\hline TOTAL & $102.594,70$ & $77,57 \%$ \\
\hline BRAQUIÁRIA & $5.626,40$ & $4,26 \%$ \\
\hline PINUS & $5.451,00$ & $4,13 \%$ \\
\hline SOJA & $5.255,80$ & $4,00 \%$ \\
\hline CANA-DE-ACÚCAR & $4.981,80$ & $3,75 \%$ \\
\hline MILHO & $2.637,70$ & $2.00 \%$ \\
\hline ALGODÃO & $2.332,40$ & $1,75 \%$ \\
\hline EUCALIPTO & $1.633,30$ & $1,23 \%$ \\
\hline AMENDOIM & 954,8 & $0,72 \%$ \\
\hline FEIJÃO & 782,6 & $0,59 \%$ \\
\hline CAPIM COLONIÃO & & \\
\hline
\end{tabular}

FONTE: SAA-ESP- PROJETO LUPA/1997

ORGANIZAÇÃO: MEDEIROS-1999. 


\begin{tabular}{|l|l|l|}
\hline MUNICÍPIO - REGENTE FEIJÓ & ÁREA CULTIVADA (ha) & PERCENTAGEM \\
\hline CULTURA & $21.519,30$ & $100 \%$ \\
\hline TOTAL & $17.443,60$ & $81,05 \%$ \\
\hline BRAQUIÁRIA & $1.212,20$ & $5,63 \%$ \\
\hline CANA-DE-AĆ́CAR & $1.168,20$ & $5,42 \%$ \\
\hline MILHO & 383,3 & $1,78 \%$ \\
\hline ALGODÃO & 305,8 & $1,42 \%$ \\
\hline FEIJÃO & 290,2 & $1,34 \%$ \\
\hline MELANCIA & 256,6 & $1,19 \%$ \\
\hline EUCALIPTO & 213,1 & $1,00 \%$ \\
\hline CAFÉ & 137,9 & $0,63 \%$ \\
\hline CAPIM NAPIER & 108,4 & $0,54 \%$ \\
\hline SORGO & & \\
\hline
\end{tabular}

FONTE: SAA-ESP- PROJETO LUPA/1997

ORGANIZAÇÃO: MEDEIROS-1999.

\begin{tabular}{|l|l|l|}
\hline MUNICÍPIO - SANDOVALINA & ÁREA CULTIVADA (ha) & PERCENTAGEM \\
\hline CULTURA & $40.706,20$ & $100 \%$ \\
\hline TOTAL & $37.571,80$ & $92,29 \%$ \\
\hline BRAQUIÁRIA & $1.072,60$ & $2,63 \%$ \\
\hline MILHO & 753,8 & $1,85 \%$ \\
\hline ALGODÃO & 484,0 & $1,18 \%$ \\
\hline CAPIM-COLONIÃO & 266,2 & $0,65 \%$ \\
\hline SOJA & 233,9 & $0,58 \%$ \\
\hline MANDIOCA & 95,7 & $0,24 \%$ \\
\hline EUCALIPTO & 91,9 & $0,23 \%$ \\
\hline CANA-DE-ACÚCAR & 91,5 & $0,22 \%$ \\
\hline MELANCIA & 44,8 & $0,13 \%$ \\
\hline SORGO & & \\
\hline
\end{tabular}

FONTE: SAA-ESP- PROJETO LUPA/1997

ORGANIZAÇÃO: MEDEIROS-1999. 


\begin{tabular}{|l|l|l|}
\hline MUNICÍPIO - SANTO EXPEDITO & ÁREA CULTIVADA (ha) & PERCENTAGEM \\
\hline CULTURAS & $7.422,40$ & $100 \%$ \\
\hline TOTAL & $6.227,40$ & $83,52 \%$ \\
\hline BRAQUIÁRIA & 356,5 & $4,80 \%$ \\
\hline FEIJÃO & 234,7 & $3,16 \%$ \\
\hline MILHO & 216,5 & $2,89 \%$ \\
\hline ALGODÃO & 96,8 & $1,30 \%$ \\
\hline CAPIM COLONIÃO & 88,5 & $1,17 \%$ \\
\hline CANA-DE-ACÚCAR & 69,0 & $0,90 \%$ \\
\hline ALHO & 69,0 & $0,90 \%$ \\
\hline TOMATE & 64,0 & $0,86 \%$ \\
\hline GUANDU & 39,2 & $0,50 \%$ \\
\hline BATATA-DOCE & & \\
\hline
\end{tabular}

FONTE: SAA-ESP- PROJETO LUPA/1997

ORGANIZAÇÃO: MEDEIROS-1999.

\begin{tabular}{|c|c|c|}
\hline \multicolumn{3}{|l|}{ MUNICÍPIO - TACIBA } \\
\hline CULTURA & ÁREA CULTIVADA (ha) & PERCENTAGEM \\
\hline TOTAL & $44.784,50$ & $100 \%$ \\
\hline BRAQUIÁRIA & $38.424,20$ & $85,79 \%$ \\
\hline CANA-DE-ACUUCAR & $3.154,60$ & $7,05 \%$ \\
\hline MILHO & $1.834,10$ & $4,10 \%$ \\
\hline SOJA & 402,7 & $0,90 \%$ \\
\hline ALGODÃO & 275,2 & $0,62 \%$ \\
\hline CAFÉ & 261,6 & $0,59 \%$ \\
\hline EUCALIPTO & 153,9 & $0,34 \%$ \\
\hline SORGO & 131,7 & $0,29 \%$ \\
\hline FEIJÃO & 96,5 & $0,21 \%$ \\
\hline AVEIA & 50,0 & $0,11 \%$ \\
\hline
\end{tabular}

FONTE: SAA-ESP- PROJETO LUPA/1997

ORGANIZAÇÃO: MEDEIROS-1999. 


\begin{tabular}{|l|l|l|}
\hline MUNICÍPIO - TARABAI & ÁREA CULTIVADA (ha) & PERCENTAGEM \\
\hline CULTURA & $21.489,40$ & $100 \%$ \\
\hline TOTAL & $19.582,10$ & $85,79 \%$ \\
\hline BRAQUIÁRIA & $1.117,70$ & $7,05 \%$ \\
\hline MILHO & 253,0 & $4,10 \%$ \\
\hline ALGODÃO & 169,0 & $0,90 \%$ \\
\hline EUCALIPTO & 146,1 & $0,62 \%$ \\
\hline BATATA DOCE & 65,2 & $0,58 \%$ \\
\hline CANA-DE-ACÚCAR & 48,5 & $0,34 \%$ \\
\hline SORGO & 38,7 & $0,30 \%$ \\
\hline MELANCIA & 37,4 & $0,21 \%$ \\
\hline ABÓBORA & 31,7 & $0,11 \%$ \\
\hline LARANJA & & \\
\hline
\end{tabular}

FONTE: SAA-ESP- PROJETO LUPA/1997

ORGANIZAÇÃO: MEDEIROS-1999. 